Florida International University FIU Digital Commons

$10-5-2016$

\title{
Explaining China's Contradictory Grand Strategy: Why Legitimacy Matters
}

Lukas K. Danner

Florida International University, ldann001@fiu.edu

DOI: 10.25148 /etd.FIDC001184

Follow this and additional works at: https://digitalcommons.fiu.edu/etd

Part of the Asian Studies Commons, Chinese Studies Commons, Comparative Politics Commons, Defense and Security Studies Commons, and the International Relations Commons

\section{Recommended Citation}

Danner, Lukas K., "Explaining China's Contradictory Grand Strategy: Why Legitimacy Matters" (2016). FIU Electronic Theses and Dissertations. 3050.

https://digitalcommons.fiu.edu/etd/3050 


\section{FLORIDA INTERNATIONAL UNIVERSITY}

Miami, Florida

\section{EXPLAINING CHINA'S CONTRADICTORY GRAND STRATEGY: WHY LEGITIMACY MATTERS}

A dissertation submitted in partial fulfillment of the requirements for the degree of DOCTOR OF PHILOSOPHY in INTERNATIONAL RELATIONS

by

Lukas Karl Danner 
To: Dean John F. Stack, Jr.

Green School of International and Public Affairs

This dissertation, written by Lukas Karl Danner, and entitled Explaining China's Contradictory Grand Strategy: Why Legitimacy Matters, having been approved in respect to style and intellectual content, is referred to you for judgment.

We have read this dissertation and recommend that it be approved.

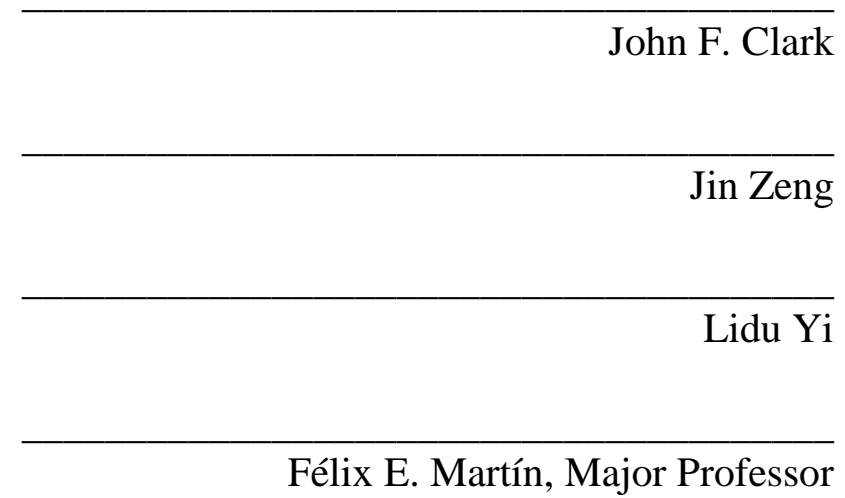

Date of Defense: October 5, 2016

The dissertation of Lukas Karl Danner is approved.

Dean John F. Stack, Jr. Green School of International and Public Affairs

Andrés G. Gil

Vice President for Research and Economic Development and Dean of the University Graduate School

Florida International University, 2016 
(C) Copyright 2016 by Lukas Karl Danner

All rights reserved. 


\section{DEDICATION}

To my parents, Doris and Karl-Gerd, and my beloved wife, Shiran 


\section{ACKNOWLEDGMENTS}

I could not have accomplished this dissertation without the help of several institutions and individuals. First, I would like to thank the Department of Politics and International Relations of the Green School of International and Public Affairs at Florida International University for the generous funding throughout the years with a teaching assistantship. Research was funded by the Chiang Ching-kuo Foundation European Association for Chinese Studies Library Travel Grant (2014) and the Anita and Morris Broad Research Fellowship (2014-15, 2015-16). This research was undertaken at the Bavarian State Library and the Library of the Institute for Sinology at LudwigMaximilians-University of Munich. I am very thankful for the help of the staff at both libraries, especially Renate Stephan-Bahle, Thomas Tabery, Andrea Kreuzpointer, and Marc Nürnberger. Further development of my dissertation was also supported by presentations at academic conferences which were generously funded by the F. A. Hayek Fund for Scholars of the Institute for Humane Studies, the Graduate and Professional Student Committee, the College of Arts and Sciences, the Steven J. Green School of International and Public Affairs, the Department of Politics and International Relations at Florida International University, the American Association for Chinese Studies, the International Studies Association, and the Nottingham Confucius Institute. Funding during the writing stage was liberally provided by the Humane Studies Fellowship of the Institute for Humane Studies at George Mason University (2015-16) and a Tuition Waiver (Fall 2015 and Spring 2016) and Dissertation Year Fellowship of the University Graduate School at Florida International University (Summer and Fall 2016). 
In my endeavor to write this dissertation, I am indebted to many scholars and colleagues who helped me along the way, first and foremost my dissertation committee. I would like to thank the participants of the panels of the conferences in which I was given the opportunity to present some chapters of my dissertation in their nascent and advanced stages, such as the East Asia Security Symposium and Conference (EASSC) in Beijing, 2013, the International Studies Association Annual Meetings in Toronto, New Orleans and Atlanta, 2014-2016, the American Association for Chinese Studies Annual Meeting in Atlanta, New Brunswick and Houston, 2012, 2013 and 2015, the European Consortium for Political Research (ECPR) Conference in Montréal, 2015, and the Joint East Asian Conference at Nottingham University and the Soft Power Conference at Westminster University, 2013. Special thanks go to Jonathan Ping and Brett McCormick who organized the EASSC in Beijing, Regina Heller and Simon Koschut who organized the panel at ECPR, as well as the discussants from the conference panels, especially Edward Friedman, Gil Murciano, Kei Koga, Murray A. Rubinstein, Jerome T. Sibayan, Naomi Standen, and Shogo Suzuki, and helpful comments from the audience, especially from Thomas Colley, Elizabeth Dahl, Lowell Dittmer, June Teufel Dreyer, Elisabeth Forster, Ajaya Kumar Das, Ning Liao, John Mowchan, Ji Hye Shin, Tracy Steele, Vincent Wang, and Thomas Wilkins.

At FIU, special thanks go to UGS Associate Director Magnolia E. Hernández, Assistant Vice Provost Sonja Montas-Hunter, and former Graduate School Dean Lakshmi N. Reddi for advancing my professional development within the AGILE program. I am very grateful to Susanne Zwingel for all the support I received from her as the International Relations Graduate Program Director. I would like to thank Markus Thiel, Paul Kowert, and Erin Kimball Damman for their general help and instruction with my 
dissertation's research design. A conversation with Ronald W. Cox has sparked my interest in what was to become my eventual dissertation topic. I thank Lidu Yi for pushing me to achieve greater rigor in the research process. Jin Zeng was invaluably helpful with the refinement of the research design and case selection and was always available for my concerns. I sincerely thank John F. Clark for his unwavering support and insightful suggestions for revisions, as well as challenging theoretical questions to address with this dissertation. Most of all, I am hugely indebted to my dissertation chair, advisor, and mentor, Félix E. Martín who was determining in giving me direction in developing the topic and underlying theory, as well as the research design; he was always available for my questions and concerns and provided much needed confidence in the research and writing process. I look back on conversations with him which lasted many hours—often beyond regular working hours. Despite having had even more support than I could have ever anticipated, the remaining errors, deficiencies and limitations of this dissertation are solely my own.

Last but not least, my thanks go to my friends who were supportive throughout my time writing the dissertation, especially Bibek Chand, Yuanyuan Fang, Maria Gabryszewska, and Nicolás Terradas. I could not have achieved what I did without the support of my family, especially my parents, Doris and Karl-Gerd, my siblings, Veronika and Laura, my grandparents and aunts, uncles, and cousins. Without having received the parenting and education prior to my university studies, my doctorate could not have been possible, which is thanks to my parents who keep on supporting me to this day. Most of all, I am forever indebted to my loving wife and best friend, Shiran, who was patient during the strenuous research and writing process, and always had my back. 


\title{
ABSTRACT OF THE DISSERTATION \\ EXPLAINING CHINA'S CONTRADICTORY GRAND STRATEGY: \\ WHY LEGITIMACY MATTERS
}

\author{
by
}

Lukas Karl Danner

Florida International University, 2016

Miami, Florida

\section{Professor Félix E. Martín, Major Professor}

This dissertation analyzed the internal incoherence of China's grand strategy. To do so, it used the cultural driver of honor to explain the contradictory behavior of China, which ranges from peaceful, responsible international actor to assertive, revisionist rising power with hegemonic ambitions. The central research question asked why China often diverges from Peaceful Development, thus leading to major contradictions as well as possible misperceptions on the part of other nations. Honor was the standard of reference that was utilized and examined in order to establish congruence and coherence between deed and praxis. Accordingly, the first hypothesis of this study posited that if policy diverges from or is incongruent with China's standard of national honor, then the grand strategy is internally incoherent. Second, two further hypotheses posited that China will tend to use peaceful means if its goal is to enhance external legitimacy, whereas it will tend to use assertive means if its goal is to enhance internal legitimacy.

This dissertation began by broadly tracing the cultural driver of honor and the link between honor and legitimacy in Chinese history. The second part of the 
dissertation looked at the six most salient events within a six-year timeframe (2009-2015) by way of the focused, comparative single-case-study method. For each grand strategy policy input (military strategy, economic policy, and diplomatic policy), the two most salient events were carefully chosen. A fourth grand strategy input, legitimacy (both internal and external), was evaluated for each of these events as well. Methodologically speaking, this study used process tracing in these within-case studies of the single case of China's grand strategy.

Results showed that China's grand strategy manifestations are by and large legitimacy-driven and that, therefore, peaceful or assertive actions may be differentiated in terms of relation to external or internal legitimacy. In sum, this dissertation advanced an innovative means of inquiry into the grand strategy of a non-Western country, contributed valuable information for the policy community, and offered results that enable a reevaluation of the debate on the peaceful or violent rise of China. 


\section{TABLE OF CONTENTS}

CHAPTER

PAGE

NOTE ON CHINESE NAMES AND TERMS $\ldots \ldots \ldots \ldots \ldots \ldots \ldots \ldots \ldots \ldots \ldots \ldots . \ldots \ldots$

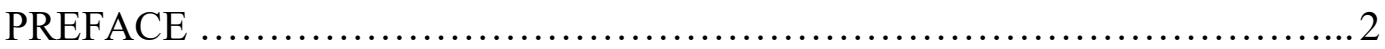

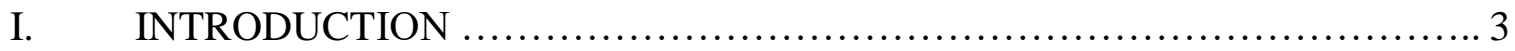

General Statement ....................................................... 3

Literature Review ................................................... 9

Significance of the Study ............................................ 17

II. RESEARCH FRAMEWORK .......................................... 19

Research Purpose .................................................... 19

Research Strategy, Design, and Approach ...................................22

III. HISTORICAL EXPERIENCE AND THEORETICAL FRAMEWORK ........ 36

Background A Missing Leading Ideology for China's Grand Strategy? ........... 37

Tracing the Cultural Drivers in China's History: Honor, Interest, and Fear ...... 41

The Tributary System, Historical Memory, and the Century of Humiliation ......52

Conceptual Definitions: Grand Strategy and Grand Strategy Incoherence ........65

Theoretical Framework: Culturalizing Grand Strategy ...................... 84

Core Argument: Honor in International Relations Equals Legitimacy for China .89

IV. WITHIN-CASE STUDY GROUP ONE: DIPLOMACY $\ldots \ldots \ldots \ldots \ldots \ldots \ldots . \ldots 6$

Case Selection and Classification ........................................ 96

The Retreat from the Non-Interference in Internal Affairs Paradigm ........... 100

The One Belt, One Road Major Diplomatic Initiative ...................... 120

V. WITHIN-CASE STUDY GROUP TWO: ECONOMIC POLICY ............ 147

Case Selection and Classification ............................................ 147

The Rare Earths Export Restrictions ...................................... 152

The Establishment of the Asian Infrastructure Investment Bank ............... 180

VI. WITHIN-CASE STUDY GROUP THREE: MILITARY STRATEGY .......206

Case Selection and Classification .......................................... 206

The Declaration of the East China Sea Air Defense Identification Zone........ 209

The Continued Participation in United Nations Peacekeeping Missions ........ 229

VII. CONCLUSION ....................................................... 249

BIBLIOGRAPHY ....................................................261

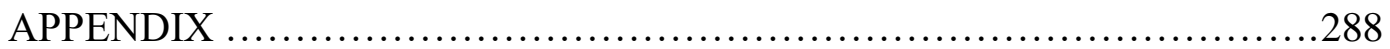

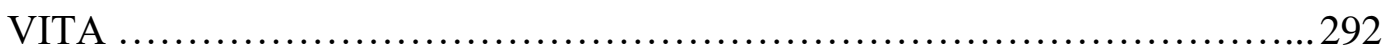




\section{LIST OF TABLES}

TABLE

PAGE

1. Two-stage explanatory framework

2. Divergence from or convergence with PD in the case of the legal non-persistence on the norm of territorial integrity in the case of the Crimean annexation and Russia-backed encroachments in Eastern Ukraine

3. Divergence from or convergence with PD in the case of China's OBOR diplomacy

4. Divergence from or convergence with PD in the case of the REE export limitations

5. Divergence from or convergence with PD in the case of the AIIB

6. Divergence from or convergence with PD in the case of the declaration of the ADIZ over the ECS

7. Divergence from or convergence with PD in the case of the continued participation in UN peacekeeping missions

8. Overview of cases concerning divergence from or convergence with PD, or both ..250

9. Overview of tested hypotheses as confirmed, disconfirmed, or both 253 


\section{LIST OF ACRONYMS}

\begin{tabular}{|c|c|}
\hline ADB & Asian Development Bank \\
\hline ADIZ & Air Defense Identification Zone \\
\hline AIIB & Asian Infrastructure Investment Bank \\
\hline APEC & Asia-Pacific Economic Cooperation \\
\hline ASEAN & Association of Southeast Asian Nations \\
\hline BFA & Boao Forum for Asia \\
\hline $\mathrm{CCP}$ & Chinese Communist Party \\
\hline DC & Developed Country \\
\hline DPRK & Democratic People's Republic of Korea \\
\hline ECS & East China Sea \\
\hline EU & European Union \\
\hline FDI & Foreign Direct Investment \\
\hline FTA & Free Trade Agreement \\
\hline HST & Hegemonic Stability Theory \\
\hline IMF & International Monetary Fond \\
\hline LDC & Less Developed Country \\
\hline NATO & North Atlantic Treaty Organization \\
\hline NDB & New Development Bank \\
\hline OBOR & One Belt, One Road \\
\hline $\mathrm{MoU}$ & Memorandum of Understanding \\
\hline P5 & Permanent Five Members of the UN Security Council \\
\hline PD & Peaceful Development \\
\hline PKM & Peacekeeping Mission \\
\hline PKO & Peacekeeping Operations \\
\hline PLA & People's Liberation Army \\
\hline PM & Prime Minister \\
\hline PRC & People's Republic of China \\
\hline
\end{tabular}




$\begin{array}{ll}\text { RCEP } & \text { Regional Comprehensive Economic Partnership } \\ \text { REE } & \text { Rare Earth Elements } \\ \text { RMB } & \text { Renminbi } \\ \text { ROC } & \text { Republic of China (Taiwan) } \\ \text { ROK } & \text { Republic of Korea } \\ \text { SCS } & \text { South China Sea } \\ \text { SDR } & \text { Special Drawing Rights } \\ \text { TPP } & \text { Trans-Pacific Partnership } \\ \text { TTIP } & \text { Transatlantic Trade and Investment Partnership } \\ \text { UN } & \text { United Nations } \\ \text { UNSC } & \text { United Nations Security Council } \\ \text { WB } & \text { World Bank } \\ \text { WTO } & \text { World Trade Organization }\end{array}$




\section{NOTE ON CHINESE NAMES AND TERMS}

Chinese terms and names are spelled using Pinyin, unless another transliteration using a different standard (e.g., Wade-Giles) is more commonly used and referred to. For example, Hong Kong instead of Xianggang for the big southern Chinese metropolis, or Confucius instead of Kong Zi.

Chinese names of authors, politicians, and historically important people are presented in the standard Chinese way of surname followed by given name. This is also done using Pinyin unless bibliographic information was recorded in the given book with another transliteration or unless the person in question is known better under a name transliterated using another standard. For example, Deng Xiaoping for the famous Communist Chinese leader, but Sun Yat-sen or Chiang Kai-shek for the equally famous Republican Chinese leaders. For books written by authors with Chinese names, the comma usually placed between the surname and first name for Western authors is omitted (e.g., "Yan Xuetong. 2014. (...)" or "Wang Yuan-kang. 2013. (...)" 


\section{PREFACE}

In the last few years, China's rise has certainly contributed to the onset of the perceived decline of the American-led, unipolar, post-Cold War international order. This dissertation deals with China's 'grand strategy,' or its international policy. The more China has grown, the more its grand strategy has come into focus in policy-making and academic circles. 'Peaceful Development' has been the chosen course for China's grand strategy as it seeks to ascend the ranks of the great power circle to which it belonged for millennia until the 'Century of Humiliation' and its aftermath. In the recent past, however, China has become more assertive in its actions and has begun to pursue its goals more aggressively and less introspectively than before. This dissertation positions itself within the debate on the coherence of China's grand strategy that has resulted from these recent actions. Whereas most other explanations rely on power transition theory or other material explanations, this dissertation attempts to solve the puzzle innovatively through a cultural inquiry focusing on China's preoccupation with gaining back the honor that it lost at the hands of the West and Japan during the 'Century of Humiliation.' In this endeavor, as with any scientific research, the aim is to be objective and systematic. This dissertation certainly

does not represent an apologist effort to rectify China's sometimes aggressive behavior. Rather, it seeks to present an explanation of China's grand strategy that makes sense to a Western audience, which may possibly help to avert a serious conflict in the future.

L.K.D.

Miami, October 2016 


\section{INTRODUCTION}

Ask ten China scholars to define Chinese grand strategy and you will get ten answers. In a formal sense, it does not exist. Yet observers can discern coherent strategic priorities that, in aggregate, resemble the elements of a grand strategy.

(Smith 2015a)

Human civilization presumably emerged twice on earth independently from each other: in China and in Europe. ${ }^{1}$

(van Ess 2013)

\section{General Statement}

China is a rising great power and its grand strategy is of utmost concern to the existing great powers in the international system, especially the United States. ${ }^{2}$ Since the prevailing perspective in these countries and in the U.S. is based, particularly, on

\footnotetext{
${ }^{1}$ Own translation from German.

${ }^{2}$ China has attracted much attention in the last decades with its perceived rise to a potential successor to the United States as global hegemon. As history shows us, seldom has there been a great power that rose without a major systemic war taking place as a consequence, like the rise of France and the Napoleonic Wars, the rise of Germany and World War One and Two, or the rise of Japan and World War Two. Because of this, China's rise is perceived to potentially endanger international peace, too.
} 
Western-centric assumptions, world politics experts in these societies often assume that in its process of ascendancy China will inevitably clash against its immediate regional neighbors as well as with other extra-regional great powers. Such a belief is compounded by mixed signals coming out of China over the last decade, i.e., incoherence of grand strategy, where official pronouncements indicate a China that views itself like a peripheral country, trying to accomplish sustained economic development and other policy goals that are inconsistent with those of a great power and rising regional hegemon. Yet, often deeds signal China's desire to assert its leadership position in the region and in the world.

This ostensible contradiction has prompted a number of world politics experts to question whether this is a purposive, strategic ploy on the part of China to confuse other international actors. Thus, this study maintains that conclusions about China's inevitable violent rise and its apparent purposive, tactical contradistinction between words and deeds for strategic gains are exceedingly superficial and simplistic. They overlook China's long social, political, historical, and philosophical traditions.

It is important to keep in mind that despite China's current re-emergence as a great power, it is an actor with a long and rich history of hegemony, great power competition, and rivalry. ${ }^{3}$ Over the millennia of existence as a politically organized unit, China has been the cradle of civilization in the Far East. This is a civilization quite distinct from the mindsets originating and shaping up on the basis of the Western Judeo-Christian tradition. Therefore, the current grand strategy of China needs to be examined inevitably

\footnotetext{
${ }^{3}$ See for example, Pant (2011), Malik (2011), Huisken (2010), Fenby (2008).
} 
in a different light from other Western great powers in order to make sense of its present and, possibly, future trajectory in global and regional politics. ${ }^{4}$

This study problematizes the current practical and intellectual contradictions in China's grand strategy with its distinctive civilizational past, and its very own ancient socio-political and philosophical ethos. In pursuing this analytical angle, this dissertation attempts to identify ideational, philosophical, idiosyncratic, cultural, historical, and religious tenets that may demonstrate ultimately if and how the origin of China's grand strategy may produce a different evolution and projection from the way that the grand strategy of Western powers has evolved and manifested itself over time.

Consistent with the line of inquiry explained above and on the basis of grand strategy theory, this work aims to establish and trace the Chinese understanding of honor in international relations history as far back as still relevant for current historical collective memory (ca. 100+ years), and the attendant grand strategy manifestations. For this purpose, Lebow's cultural motive of honor is fundamental. ${ }^{5}$ Accordingly, this dissertation explains

\footnotetext{
${ }^{4}$ This is contrary to the belief of some realists that a theory of realism may be applied through time and space, and without any regard for cultural values, norms, or beliefs. See, e.g., Waltz (2010 [1979]), or Mearsheimer (2003).

${ }^{5}$ See Lebow (2009), 43ff. Another motive identified by Lebow is 'reason' which is not taken into account in the set-up of variables for the present study, but may be referred to in the analysis. Also, Lebow generally refers to honor as 'spirit,' and to economic interest as 'appetite,' which this study does not for the sake of clarity.
} 
how honor as conveyed from ancient times leads China's current grand strategy policy inputs to appear contradictory resulting in an incoherent grand strategy.

The notion of grand strategy is at the core of this study. The origin of this concept stems primarily from the history of the Western world. It is based largely on the experience of the European great powers and the United States. Thus, it is imbued greatly by the Judeo-Christian tradition. Grand strategy can be defined as the general, long-term security and foreign policies of a territorial state. Grand strategy attends to the national interests of a state through the use of all means of statecraft available or at the disposal of a country, namely, economic, military, diplomatic, political, financial, and informational tools. While subscribing to the assumption that national interest always means security and survival of the nation-state in question, in China's case additionally, the national interest is assumed to entail the preservation of its territorial boundaries and integrity, recovering territory regarded as lost, gaining the international acceptance and recognition as the only legitimate government to represent China internationally, and improving its status on the world-scale (Teufel Dryer 2012, 331).

To be clear, 'internal coherence' of any nation's grand strategy is defined here as "the manner in which different policies within a grand strategy design support or undermine each other" (Papasotiriou 1992, p. v). In the case of grand strategy incoherence, the policy inputs, i.e., "military strategy, economic policy, diplomacy, and legitimacy" (Ibid., p. v) will then undermine each other. In China's case, its general grand strategy of "Peaceful Development (or Rise)" (PD) and 'Keeping a Low Profile' contradicts the 
recently rising and bold assertiveness that it notably exhibits in the East China Sea (ECS) and South China Sea (SCS). Yan Xuetong argues that there was a grand strategy shift from the previous grand strategy to one that he calls 'Striving for Achievement' (2014). Others argue that China exhibits a grand strategy along the lines of 'Selective Leadership,' alluding to the grand strategy notion advanced by Robert J. Art as 'Selective Engagement' (Chen 2014). Confucianism, which China has used historically as the official state ideology, contradicts China's current power politics, sable rattling, and muscle flexing in the region as well as several other historical instances. Similarly, PD contradicts the rising assertiveness of China. This dissertation explains the incoherence of China's grand strategy. This means that it operates on two assumptions: First, this dissertation assumes that China is not undergoing a change from one grand strategy to another; ${ }^{6}$ and second, China (as well as any other great or rising power) actually has a grand strategy. In short, this dissertation accepts the existence of a longitudinal Chinese grand strategy.

By definition, grand strategy utilizes all tools of statecraft at the disposal of the nation-state to reach strategic objectives in the military, diplomatic, and economic realms. Accordingly, grand strategy incoherence is when means are used to attain policy goals that are radically different from those that have been enunciated by key national policy-makers and leaders. In the military, diplomatic, and economic realms, strategic

\footnotetext{
${ }^{6}$ That is so, if one subscribes to the belief that China's grand strategy is in fact changing from one to another, as Yan Xuetong argues. This dissertation does not subscribe to this.
} 
policy refers to the rational use of military, diplomatic, and economic tools in order to advance and protect a nation-state's national security interest in these three policy spheres. ${ }^{7}$

Grand strategy, as a theoretical framework, would prescribe that all means at China's disposal would be aligned to achieve vital, national interest objectives. ${ }^{8}$ However, given the major incoherence in China's grand strategy design, its strategic policies may very well undermine its national interests. These contradictions constitute the puzzle that this dissertation attempts to decipher and explain. ${ }^{9}$ Given China's rising assertiveness in the aftermath of the Global Financial Crisis, this dissertation sets out to explain China's grand strategy since 2009, i.e., when contradictions in grand strategy manifestations rose dramatically. This study's analytical framework combines grand strategy theory ${ }^{10}$ with the approach championed by Lebow, i.e., to take into account 'honor' as cultural driver in analyzing international relations. ${ }^{11}$

\footnotetext{
${ }^{7}$ While this definition is broad, the research design with the case studies are going to select singular, most salient events of grand strategy manifestations which stay within this broad definition, however, representing narrow parts of it. In this way, the research becomes more feasible.

${ }^{8}$ For the flexibility and definition of the concept of national interest see Rosenau (1968), Hill (2013), or Clinton (1994), among others. Since this dissertation subscribes to using the inherently realist concept of grand strategy, it also subscribes to a realist understanding of national interest as universally being security and survival of the nation-state. Still, different countries may have different grand strategy goals.

${ }^{9}$ That is, if one subscribes to the belief that China's grand strategy is in fact changing from one to another, as Yan Xuetong argues. This dissertation does not subscribe to the notion of a transformation of China's grand strategy but, rather, to the peculiarity of its basic incoherence.

${ }^{10}$ See Papasotiriou (1992). For further reading on grand strategy, see, e.g., Brands (2014), Dueck (2006), Freyberg-Inan, Harrison and James (2009), Kapstein and Mastaduno (1999), Kay (2011), Layne (2009), Lobell (2003), Lobell, Ripsman and Taliaferro (2009), Mahnken (2012), Taliaferro, Ripsman and Lobell (2012), or Taylor (2010).

${ }^{11}$ See Lebow (2009), 43-164, and 505-570.
} 


\section{Literature Review ${ }^{12}$}

\section{Literature Examining Historical Chinese Grand Strategy}

Wang Yuan-kang raises similar questions and argues exactly about the internal contradiction in Chinese grand strategy. That is, while historically, China has preached 'harmony,' consistent with its official Confucian state ideology, it actually has acted, as offensive realism would have predicted it would: Behaving more offensively and aggressively when it had a large amount of capabilities, and defensively when it did not (Wang 2001). Essentially, Wang concludes that China did not behave at all different from the way that any Western great power would have behaved in the world stage. Wang is clearly an offensive realist, ${ }^{13}$ who naturally would argue that 'soft' variables like ideology or cultural, philosophical, social tenets do not influence international relations, and that, essentially, realism may be applied to all and every nation past, present, and future. Indeed,

\footnotetext{
${ }^{12}$ Part of this sub-chapter appeared as blog post publication in "The Debate on China's Grand Strategy" in China Policy Institute Blog (University of Nottingham, UK). Available online at http://blogs.nottingham.ac.uk/ chinapolicyinstitute/2015/05/04/the-debate-on-the-direction-of-chinas-grandstrategy/ (May 2015).

${ }^{13}$ Defensive and Offensive realists see the international system as anarchic. They focus on states which they see as unitary, monolithic actors. This is different from liberal International Relations scholars who see the state as permeable, meaning that interest groups within a state, as well as organizational processes, are of relevance to them. Realists tend to see the national interest of a state rather than multiple interests from different groups within a state. For realists, the national interest can usually be defined as survival and security of the state for defensive realists, and power maximization for the sake of security for offensive realists. Realists see their grand theory of international relations as universally applicable through time and space, with no need to take culture, values, or the like into account. This may also be due to the theoretical parsimony of realism, i.e., they strive for as little variables as possible to explain or predict something.
} 
it is a powerful conclusion; it misses, however, a richer and nuanced analysis of the internal incoherence of China's grand strategy. Had it been done, it would have yielded a radically different interpretation of the evolution, and present and possibly future manifestation of China's grand strategy. This is precisely what this dissertation attempts to accomplish by way of the hybrid analytical framework advanced in this study.

Johnston separates the Confucian strategic culture from China's actions and defines a Chinese strategic culture that resembles power politics, realism, in many ways, i.e., the so-called Parabellum strategic culture (Johnston 1995). Another scholar, Huiyun Feng, concludes that rather than territorial conquest, 'cultural conquest' was much more important to China, historically speaking. This is because China's Confucian state ideology highlights prominently the importance of peacefulness. For Feng's application to Mao's and Deng's foreign policy, she finds, however, that they were more defensive on the whole than Johnston or Wang would have argued (Feng 2009; Feng 2007).

\section{Literature Examining China's Grand Strategy Incoherence Specifically}

Concerning the present, Qin Yaqing argues that China does not have either 'Keeping a Low Profile' or 'Striving For Achievement' grand strategy but, rather, it is inherently 'Chinese' to take the 'middle course'; Qin refers to this Zhongyong dialectic as being "one of the core components constituting background knowledge that it is commonly shared in the Chinese cultural community (...) which argues, inter alia, that the middle 
course is usually more appropriate than any involving extreme behaviour" (Qin 2014, 287). A completely different argument, Shi Yinhong, among others, argues that China does not have a grand strategy at all, this being the top problem of China's security and foreign policy (2001). Yet others, like Eric Hyer, maintain that the fact that China's grand strategy does not have a clear line should be considered as 'pragmatism' (Hyer 2014). ${ }^{14}$

Barry Buzan claims that

China lacks a coherent strategic vision of its place in international society, and fails to align ends and means, combining rhetoric of peaceful development and harmonious relations with several militarized border disputes with its neighbours, a lot of hard realist rhetoric, and political relationships bordering on enmity with Japan, Vietnam, and India.

$(\text { Buzan 2014, 2; Buzan 2010) })^{15}$

Nevertheless, Buzan rejects the validity of questioning the existence of a Chinese grand strategy:

\footnotetext{
${ }^{14}$ See also, e.g., Zhao (2004).

${ }^{15}$ Although, the "lack[ing] a coherent strategic vision" (Buzan 2014, 2) could also be calculated strategic ambiguity on the part of China, and therefore knowingly made part of its own grand strategy-depending on one's conviction. Whether strategic ambiguity is an inherently "Chinese" characteristic of China's grand strategy will have to be part of the analysis in this dissertation.
} 
The question is therefore not whether China does or doesn't have a grand strategy. It does. The key issue is whether the logic of this grand strategy, and the contradictions within it, are fully understood, and whether China has sufficient depth and coherence in its policy-making processes to implement such a strategy

(Buzan 2014, 4)

For Buzan, it boils down to

whether China want (sic!) to use its rising power to look forward, and help create a more pluralist, de-centered international society in the post-Western age, or look backward, seeking vengeance for the century of humiliation and to restore a Sino-centric system in East Asia.

(Ibid., 38).

Yan Xuetong maintains that for China to pursue

political leadership based on humane authority will benefit a rising power in establishing a favorable international environment. (...) According to moral realism, China made great diplomatic achievement with the Striving for Achievement strategy in 2013 mainly because of the shift of its foreign policy from an economic orientation to a political orientation. Differing from the Keeping a Low Profile with a core value of economic benefits, the 
Striving for Achievement gives the priority to political dignity over economic interests,

(Yan 2014, 182)

which Yan sees as making friends, so as to enable China to have more allies than the U.S. and achieve a status as a world leader. Yan sees 'Keeping a Low Profile' as defeating that goal, as

unfortunately, the core value of the Keeping a Low Profile was accumulation of wealth, which is regarded as selfish rather than a moral value in every civilization. That means the core value of the Keeping a Low Profile undermines China's image in the world and is harmful to the implementation of national rejuvenation.

(Ibid., 184)

Some constructivists, such as Courtney J. Fung (née Richardson) and Xiaoyu Pu, have tried to explain China's grand strategy incoherence on the basis of China's dual identities. First, they portray China as an ambitious, rising great power, perceived to be at the level of the U.S., and, second, as a leader of the developing world, with the selfunderstanding that it is still part of it. (Pu 2012; Richardson 2012). While the latter studies have some validity in explaining Chinese grand strategy contradictions, this study aims to add nuance and more substance to the debate by connecting the current incoherence to China's history. 
Connolly and Gottwald have attempted a longitudinal, article-length study of China's foreign policies via a pure application of Lebow's Cultural Theory (Connolly and Gottwald 2013). They arrive at the conclusion that appetite and honor are determining in China's quest to change the international order, but that it is mainly honor.

\section{Literature Review Synthesis}

While there are some similarities between Connolly and Gottwald's work and this dissertation, this study diverts significantly from their analysis in several ways: First is the longitudinal focus. This study narrowly traces historical and philosophical evidence since 2009 to 2015 , and not, as they do, broadly concentrate on the last century of China's foreign policies. Second, this study synthesizes and connects specifically the cultural motive of honor with grand strategy theory and is not a pure application of Lebow's argument with all three cultural drivers. Third, this dissertation does not merely advance a general analysis of China's foreign policy, as Connolly and Gottwald set out to, but more specifically, examines its grand strategy. Finally, this work specifically addresses the internal incoherence of China's grand strategy, and not all aspects of China's general foreign policy as Connolly and Gottwald do in their study.

Whereas Yan's argument is mostly normative and seeks to be a policy prescription for China's government, this dissertation seeks to be an empirical analysis with some inclusion of normativity. As demonstrated above, there is a plethora of differing 
arguments about China's current grand strategy, but there is little or no research tracing China's history and taking the past into account for a comprehensive analysis of its recent grand strategy inconsistencies. The above-mentioned studies analyze mostly China's current grand strategy through an application of their own, for the most part 'Eurocentric,' theoretical paradigm. Conversely, this dissertation adds nuance to the debate on China's grand strategy by way of an accommodating analytical framework that promises a more balanced and inclusive explanation of China's grand strategy. ${ }^{16}$ As explained above, Yan's insightful argument is too normative to be useful in accounting for an objective empirical analysis of China's current grand strategy. Rather, it is a prescription for what it should become.

Buzan's study of current contradictions in China's grand strategy is at times insightful regarding recent Chinese historical memory. Nonetheless, this dissertation seeks to go beyond that threshold and provide more historical richness about how the past may be influencing the present.

Also, by exclusively analyzing the historical international relations of China during imperial times, like Johnston, and Wang do, cannot shed sufficient light on the grand

\footnotetext{
16 "Accommodating" means the addressing of the Western-centrism in the existing International Relations theories. A pure application of the theory of grand strategy would yield likely incorrect results because of the civilizational distinctiveness of China to the Western Judeo-Christian tradition and the related International Relations theories that are at a researcher's disposal. Therefore, a synthesis of Lebow's cultureaccommodating framework with that of grand strategy theory may yield a much more accurate analysis and its findings may be more valid. Hence, one could deem such a theoretical framework as more "accommodating."
} 
strategy of a country like China operating in the modern, "Westphalian" international system. In this context, systemic conditions have changed significantly over the millennia and policy insights from imperial times have limited or no direct relevance to the present. Also, Johnston's, Wang's, and Feng's studies are more about grand strategy choice and, therefore, more useful for predicting China's future grand strategy behavior, whereas this study sets out to explain the incoherence in China's grand strategy design. It does not make a strategic culture argument, like the aforementioned scholars attempted to do.

Qin Yaqing's constructivist argument is insightful but is aimed at explaining the existence of two different grand strategies at the same time. It presents a good starting point for this dissertation though, as do many of the other works above. Rectifying assertiveness on the part of China, like the arguments of Qin Yaqing or Yan Xuetong, is also not the aim of this study. ${ }^{17}$

Certainly, no 'one-size-fits-all'-argument à la pure forms of defensive or offensive realism, is intended in this dissertation. Nevertheless, this study acknowledges that realism captures best the dynamics of international relations, especially concerning

\footnotetext{
${ }^{17}$ This literature review is merely a selection of important, recent studies on China's grand strategy. It exemplifies the variety of arguments on China's grand strategy nicely, though. For further studies on China's grand strategy, see, e.g., Adamson (2013), Ambrosetti (2012), Callahan (2013), Christensen (1996), Christensen (2011), Goldstein (2005), Harding (2013), Hsiao and Lin (2009), Hu (2011), Huang (2010), Huang (2012), Ikenberry (2013), Kane (2002), Kissinger (2012), Kober (2006), Nathan and Scobell (2013), Nathan and Scobell (2012), Nathan (2011), Nathan and Ross (1997), Ross and Feng (2008), Roy (2013), Saha (2013), Saunders (2006), Steinberg and O'Hanlon (2014), Swaine, Daly and Greenwood (2000), Wang (2011), Ye, Levine and Liu (2011), Ye (2010), or Zheng (2005).
} 
conflicting national grand strategies. Combining the theory of grand strategy with the cultural theory of Ned Lebow presents a better theoretical framework than any of the existing International Relations theories which are based on the experience of the West. This means this newly combined framework of a realist concept with a culturalist approach takes account of China's civilizational distinctiveness while remaining in the 'real world.' In many ways with Qin Yaqing's approach, particularly his point about the importance of background knowledge to understand the incoherence of China's grand strategy, i.e., a cultural explanation, can be further elaborated with this study's synthesized theoretical framework. Therefore, this study amends the realist theory of grand strategy with Ned Lebow's cultural framework-focusing on 'honor'-in its explanation about the incoherence of Chinese grand strategy putting it into historical, cultural, and ideological perspective. The light shed on China's grand strategy and how China's past relates to its current manifestations, should be most objective and free from sinophilia or sinophobia in this fashion, while still accommodating China's distinctness from the Judeo-Christian tradition.

\section{Significance of the Study}

Compared to the existing literature, this study is innovative in the way that, first, it analyzes the most recent manifestations of Chinese grand strategy; second, it incorporates China's civilizational distinctiveness; third, provides a new, synthesized and "culturalized" framework for the specific analysis of grand strategy of a non-Western 
country while still taking material factors into account and therefore staying policy-relevant; fourth, unlike previous studies about grand strategy choice of China, ${ }^{18}$ it adds scholarship to a very current debate on China's grand strategy design incoherence; and, fifth, it offers the theoretical synthesis of grand strategy and cultural drivers to explain an internally incoherent grand strategy which has never been attempted before.

The results enable a better and more holistic understanding than previously held, especially for Western audiences, of current Chinese grand strategy and its future direction. Therefore, the findings may be very policy-relevant for the U.S. policy toward China. Also, the general conclusions of this dissertation may add nuance to the theory of grand strategy, especially as it concerns future applications on non-European great powers using its newly developed, synthesized framework (e.g., Japan, India, Brazil). Last, the employed analytical framework and sources entail an interdisciplinary approach, spanning the disciplines of International Relations and History. In the process of investigating the practical and intellectual incoherence between China's current grand strategy with its past, this dissertation may be in a position to re-evaluate the scholarly debate on China's peaceful or violent rise as a great power and contribute to a richer and more accurate understanding of China's regional and global role in the next several years.

\footnotetext{
${ }^{18}$ As compared to studies analyzing the historical grand strategy of China, like those of Feng (2009), Wang (2001), or Johnston (1995).
} 


\section{RESEARCH FRAMEWORK}

Neither theories nor cases are sacrosanct. Cases are always too complicated to vindicate a single theory, so scholars who work in this tradition are likely to draw on a mélange of theoretical traditions in hopes of gaining greater purchase on the cases they care about. At the same time, a compelling interpretation of a particular case is only interesting if it points to ways of understanding other cases as well[.]

(Peter Evans in Kohli et al. 1995, 4)

\section{Research Purpose}

This dissertation investigates the possible link between the original, ancient ethos of China, which developed over centuries, and those prevailing in present day China as created and reflected in the seemingly internal incoherence of China's grand strategy today. Accordingly, the primary purpose of this study is two-fold. First, to make sense of the current internal incoherence in China's international strategy by way of a historical, socio-cultural explanation-as opposed to an organizational, or geopolitical-material one- - using a new, synthesized framework. In this investigative pursuit, this study attempts to add nuance generally to the theory of grand strategy. Once this first part is accomplished, a second objective of the study emanates naturally, placing this dissertation in position to 
re-evaluate the debate on the peaceful or violent rise of China as a great power in the near future.

To prevent a pure application of Western-centric grand strategy theory on the Chinese case yielding wrong results and similarly ousting the very same theory as quintessentially 'Eurocentric,' this dissertation further develops grand strategy with the synthesis of this concept with the cultural theory of Lebow. Grand strategy—even though it may be 'Eurocentric' in its origin — is still quite useful to illuminate China's great power policies. China does not coexist in a political vacuum. Instead, it is an international player that operates in the international system that is inherently dominated and guided by norms, principles, rules set primarily by the West, especially the U.S. ${ }^{19}$ However, to adjust it better to the Chinese civilizational case, a synthesis with Ned Lebow's Cultural Theory (2009) is advanced in this study by taking into account the cultural driver of 'honor' in order to create a new theoretical framework mindful of the distinct Chinese experience, and, accordingly, rectify assumptions based on Chinese civilizational texts.

On the whole, this dissertation amends-or complements - the general framework of the theory of grand strategy and synthesizes it with that of Lebow's cultural theory insofar as it emphasizes the cultural driver of honor (in pursuit of prestige and status) — while relating honor specifically to the Chinese ancient imperial experience or

\footnotetext{
${ }^{19}$ See, for example, Bull and Watson (2014 [1984]), Gong (1984), Suzuki (2009), and Wang (2013).
} 
historical sources. ${ }^{20}$ In his A Cultural Theory of International Relations (2009), Ned Lebow attempted to construct a new grand theory of International Relations by elaborating on points that he saw neglected by the other grand theories, such as realism, Marxism, or liberalism. Lebow's theory

is based on a simple set of assumptions about human motives. Following the Greeks, [he] posit[s] spirit, appetite and reason as fundamental drives with distinct objects or ends. These give rise to distinctive forms of behavior that have different implications for cooperation, conflict and risk-taking.

(Lebow 2009, 26)

Lebow goes on to define ideal-type worlds based on each of the three cultural drivers, however, conceding that in the 'real world' of modernity "[m]ultiple motives generally mix rather than blend, giving rise to a range of behaviors that can often appear contradictory" (Lebow 2009, 27; italics added).

As evident from the last part of this excerpt, fusing Lebow's findings with the theory of grand strategy may be creating a good theoretical framework to illuminate the contradictions in China's grand strategy manifestations. Especially the 'honor' cultural motive in Lebow's theory is what makes his approach distinct from realist or other existing

\footnotetext{
${ }^{20}$ Lebow's complete framework contains three drivers of international relations, i.e., interest (to the end of wealth), fear (to the end of security), and honor (to the end of prestige/status).
} 
theories that already take into account the search for wealth (driven by 'appetite/interest') or the search for security (driven by 'fear'). Lebow then

develops a paradigm of politics based on the spirit and the need for selfesteem to which it gives rise. Following Plato and Aristotle, I contend this need is universal and distinct from appetite. The spirit is an individual drive but has great importance for politics because people seek self-esteem not only through their personal activities, but vicariously through the achievements of social units to which they feel attached, such as sports teams and nations. [ ... ] To build identities and mobilize public support, states construct and project characters and narratives of themselves to which many of their citizens become deeply attached. Policy-makers find it in their interests to act—or give the appearance of acting - in terms of these characters and narratives, which can restrain their freedom of action and at times compel them to pursue policies at odds with their preferences. For citizens and leaders alike, questions of standing and honor can be very important and interrelated. [However, t]he concept of the spirit all but disappeared from the philosophical and political lexicon as a result of the Enlightenment and French Revolution.

$(2009,122-123)$

As far as fusing these theoretical insights from Lebow with that of grand strategy, this dissertation may be in a position to explain the grand strategy design 
incoherence on the basis of the cultural driver of honor. This would be achieved by arguing that 'interest' and 'fear' have begun to fail to constrain the driving force of 'honor' and, therefore, China has moved to become more risk-accepting in its behavior, i.e., assertive.

This dissertation, therefore, asks the following questions: First and foremost, why are there contradictions in the implementation and communication of Chinese grand strategy? Second, how is the conduct and formulation of Chinese current grand strategy influenced by the cultural driver of honor, and is there a historical 'golden thread' to that? Third, if China's grand strategy is still influenced by the cultural driver of honor as conveyed through the centuries, is it critical in explaining the grand strategy contradictions? Fourth, does the influence of the cultural driver of honor on the different policy inputs result in the internal incoherence of grand strategy design? And, possibly, fifth, is there a situational pattern of when China breaks the coherence of its grand strategy, i.e., under what circumstances does China diverge from its proclaimed grand strategy?

\section{Research Strategy, Design, and Approach}

This dissertation empirically examines the main research question of why China's grand strategy comes across as contradictory judged by its actions at face value. Is China's grand strategy critically influenced by the cultural driver of honor (in pursuit of prestige/status) and is there a relation to history? And, if so, how does this result in an internal incoherence of China's current grand strategy? 
The research design approach this dissertation employs to achieve these objectives is close to the case study approaches as outlined by van Evera, Harry Eckstein, Arend Lijphart, and George and Bennett, and complement the historical process-tracing method employed within the case study design taking into account ancient as well as recent sources to ensure valid conclusions: ${ }^{21}$ The design and implementation of the case study approach consists of three phases:

In phase one, the objectives, design, and structure of the research are formulated. In phase two, each case study is carried out in accordance with the design. In phase three, the researcher draws upon the findings of the case studies and assesses their contribution to achieve the research objective of the study[.]

(George and Bennett 2005, 73)

Generally put, in such an approach case studies surrounding a central research question are employed to identify patterns and —on the basis of this—develop (or test) a theory on the subject, i.e., the central research question. A theory of China's grand strategy, per se a single case study, is therefore advanced by a close look at three different areas of China's interaction with the world: political/diplomatic interactions, economic interactions, and military/power-political interactions with the outside world, regionally, and internationally. The time frame of this study is limited to the last couple of years

${ }^{21}$ See George and Bennett (2005), Eckstein (1975), Lijphart (1971), and Van Evera (1997). 
beginning with the year 2009, i.e., the rough on-set of China's changed perception in the aftermath of the global financial crisis or supposed paradigm change in China's recent grand strategy of 2008/2009 with rising assertiveness. The investigation of this case study is preceded by a chapter that historically traces honor in China's newer history which is underlying China's interactions with and strategy toward the international community, and perception of its place within the outside world.

In brief, the research design described in the following section consists of and fulfills five tasks as stipulated by George and Bennett which they call "phase one" of the case study:

Task one: Specification of the problem and research objective[;] Task two: Developing a research strategy: specification of variables[;] Task three:

Case selection; Task four: Describing the variance in variables; Task five: Formulation of data requirements and general questions.

$(2005,73-88)$

\section{Phase One: Formulation of the Objectives, Design, and Structure}

This first phase is achieved in the first chapter of this dissertation, while phase two, i.e., "carrying out the case studies" (Ibid., 89), and phase three, i.e., "drawing the implications both for theory development and theory testing" (Ibid., 109), is achieved 
in the chapters constituting the main research part of the dissertation, as well as in its conclusion.

\section{Specification of the Problem and Research Objective}

To specify the problem and research objective, i.e., the first task of designing a case study, this dissertation aims to explain the internal incoherence of China's current grand strategy. The main research objective is the identification of the reasons for the internal incoherence in China's grand strategy and how the different policy inputs, which there are military strategy, economic policy, diplomacy, and legitimacy, may or may not undermine each other. In an effort to apply the theory of grand strategy on the distinct Chinese case, the dissertation develops a new, synthesized theoretical framework-both based on grand strategy theory as well as on Lebow's cultural theory. As such it relates the cultural driver of honor which has as its end prestige, status, reputation, and recognition to the grand strategy design policy inputs and analyzes the role of it within each of them. In an effort to develop this framework, this dissertation asks which of the cultural drivers take prevalence and how they contribute to the undermining of the policy inputs and therefore the result of internal incoherence. ${ }^{22}$

\footnotetext{
${ }^{22}$ As mentioned above, "internal coherence" of any nation's grand strategy is defined as "the manner in which different policies within a grand strategy design support or undermine each other" (Papasotiriou 1992, p. v). The policy inputs which may undermine each other are defined as "military strategy, economic policy, diplomacy, and legitimacy" (Ibid., p. v).
} 


\title{
Developing a Research Strategy: Specification of Variables
}

The second task of the creation of a research design is to develop a research strategy and therefore also specifying variables, i.e., the outcome/effect which is to be explained by this study, the determinants that comprise the theoretical framework. The outcome which this study attempts to explain is the contradiction in China's grand strategy. This is pursued by an examination of the different policy inputs for internal grand strategy design: first, the policy input of 'military strategy,' second, policy input of 'economic policy,' third, policy input of 'diplomacy,' and fourth, policy input of 'legitimacy' (the latter one within each of the selected cases). The cultural driver of 'honor' is treated as first stage explanation of the contradictions within the grand strategy manifestations in the military, economic, and diplomatic realms.

\author{
Cultural Driver \\ Grand Strategy Manifestations \\ / Within-Case Studies \\ Outcome / Puzzle \\ Military strategy \\ (incl. internal/external \\ legitimacy thereof) \\ Economic policy \\ Honor \\ (in search for prestige) \\ (incl. internal/external \\ legitimacy thereof) \\ Contradictions in \\ China's grand strategy \\ (internal incoherence) \\ Diplomatic policy \\ (incl. internal/external \\ legitimacy thereof) \\ First stage: \\ Honor explains contradictory grand \\ strategy manifestations \\ Second stage: \\ Contradictory grand strategy \\ manifestations \\ explain incoherent grand strategy
}

Table 1: Two-stage explanatory framework. 


\section{(Within-)Case Selection}

This dissertation deals with a single case: China's internal incoherence in its grand strategy design. Because this is a country-specific problem, in an effort to augment the number of empirical observations for testing co-variation, the single case selection is subdivided further into several "within-case" instances. As mentioned above, these are based on the different kinds of policy inputs of grand strategy: first, China's military strategy, second, China's economic policy, third, China's diplomacy, and, fourth, for each of the three instances of policy inputs — rather than its own separate or independent case study - degrees of internal and external legitimacy are assessed in light of each of the above-listed policy inputs. Finally, each of the three focused policy-input cases are subdivided into two further cases, i.e., two most salient events in the selected timeframe. The aim in selecting these cases is to select one event that suggests consistency between the proclaimed PD grand strategy, and another that reveals the undermining of the proclaimed grand strategy and, thus, engagement in power-politics and rising assertiveness.

As previously mentioned, for the sake of the topic and because of the assumed paradigmatic change in grand strategy, the dissertation focuses on China's outside interactions since 2009.

For the within-cases pertaining to the grand strategy design input category of diplomatic policy, first, China's reaction to the Russo-Ukrainian conflict is selected as one of two salient events. The second most salient event analyzed is the 'One Belt, One 
Road' (OBOR) diplomatic initiative. These two events can clearly be said to have had high importance for the diplomatic policy input into China's grand strategy. While the former shows more signs of being related to internal legitimacy — China initially taking Russia's, i.e., the revisionist side - the latter speaks to external legitimacy with a clear attempt to solicit recognition from adjacent regions.

For the within-cases pertaining to the grand strategy design input category of economic policy, the first most salient event chosen is China's export restrictions for rare earth elements (REEs); these were mainly directed against Japan which needs these natural resources, e.g., for its large semi-conductor and car industries. This event was advantageous for China's internal legitimacy, while rather negative for external legitimacy with the West. The second event selected is China's proposal for and the eventual establishment of a new Asian development bank, the Asian Infrastructure Investment Bank (AIIB); it is an example which is also driven by China's search for prestige and, especially, external legitimacy, which interestingly still raises some reservations on the part of the U.S.

For the within-cases pertaining to the grand strategy design input category of military strategy, the first selected event is China's declaration of an Air Defense Identification Zone (ADIZ) over the East China Sea (ECS) in late 2013-also related to Sino-Japanese rivalry escalating between 2012 and 2014 in particular. This action on the part of China certainly contradicted its PD grand strategy because going aggressively against the reigning, extra-regional hegemon and its intra-regional ally is not truly in the interest of China; the worsening of Sino-Japanese relations was advantageous for internal 
legitimacy, while disadvantageous for external legitimacy. The second selected example for this within-case study group is China's participation in United Nations (UN) peacekeeping missions (PKMs); externally, as well as internally this may be seen as legitimacy-increasing.

After the general and conceptual introduction of the topic, research strategy, and historical-cultural theoretical framework (first and second chapter), and after focusing on identifying and tracing China's historical experience in relation to the cultural driver of honor in current grand strategy manifestations (third chapter), the above-mentioned six within-cases are examined (fourth, fifth, and sixth chapters), followed by a conclusion (seventh chapter).

There are, of course, several reasons why China itself is a well-selected case for the application of the concept of grand strategy, as elaborated above: the long history as regional hegemon and great power in East Asia, as well as its current importance for world order; China is a very good case for an analysis that highlights connections of history, philosophical concepts, and cultural mindset with current grand strategy, especially since many historical documents have been traduced through its official historiography and endorsement of certain philosophical currents as official state ideology. ${ }^{23}$ Also, China seems to be an outlier case, when it comes to applying grand strategy; a case that clearly

${ }^{23}$ See George and Bennett (2005), 83f. 
puzzles International Relations scholars exemplified by recent dissertations, ${ }^{24}$ and debates. ${ }^{25}$ The analysis of such "cases can uncover new or omitted variables, hypotheses, causal paths, causal mechanisms, types, or interaction effects" (Ibid., 109) for the sake of theory development. This means, that even though this study is focused on a single case through multiple within-case studies, it can still add nuance to theory, i.e., that of grand strategy, besides answering the country-specific research question via a theoreticallyinformed empirical investigation.

\section{Formulation of Data Requirements through General Questions}

Last, the formulation of data requirements through general questions, i.e., task five of designing case study research, means that analytical inquiry in the three different within-case groups of this dissertation are standardized by asking the same general questions from each case. In this way, the results from each within-case of this single-case study may "be compared, cumulated, and systematically analyzed" (Ibid., 86).

As mentioned above, these are the general questions that this dissertation addresses: First and foremost, why are there contradictions in the implementation and communication of Chinese grand strategy? Second, how is the conduct and formulation of

\footnotetext{
${ }^{24}$ See, e.g., Richardson (2012), or Pu (2012).

${ }^{25}$ See, e.g., Buzan (2014), Luttwak (2012), Qin (2014), or Yan (2014).
} 
Chinese current grand strategy influenced by the cultural driver of honor, and is there a historical golden thread to that? Third, if China's grand strategy is still influenced by the cultural driver of honor as conveyed through the centuries, is it critical in explaining the grand strategy contradictions? Fourth, does the influence of the cultural driver of honor on the different policy inputs result in the internal incoherence of grand strategy design? And, possibly, fifth, is there a situational pattern of when China breaks the coherence of its grand strategy, i.e., under what circumstances does China diverge from its proclaimed grand strategy?

Correlating with these general questions, the study relies on literature documenting the relations of China within its imperial tributary system, and with peoples outside of this system ('barbarians'); other sources used are current government documents, such as white papers, and other official publications by the government, including those by the official government news agency, Xinhua.

\section{Limitations of Research Scope}

In an effort to stay relevant and for the purpose to accommodate a possible strategic shift that might have taken place since 2008, this study has only used a timeframe

of six years. With that it is more or less possible to exclude that the empirical cases match the strategic orientation of China. 
This dissertation operated under the assumption that it is possible to make out a country's grand strategy, even if it has not officially announced it and laid open in detail. The assumption is that any major power will have a grand strategy in pursuit of its security and survival.

Some analyzed cases are of an on-going, unfinished fashion. The territorial disputes in the seas surrounding China, and the proposal and foundation of the AIIB - and how it is going to operate long-term, are under development. Whether China will continue on as it did with peacekeeping operations led by the UN also remains to be seen.

\section{Notes on Phases Two and Three}

Each case is individually analyzed with the goal being to answer the general questions that are asked; the results are "“answers' to the general questions. These answers - the product of phase two - then constitute the data for the third phase of research, in which the investigator will use case findings to illuminate the research objectives of the study" (Ibid., 89).

In this dissertation's case, these answers are related to the contradictions in China's grand strategy, i.e., the research objective of the dissertation. ${ }^{26}$ Finding the answers,

${ }^{26}$ See, for example, George and Bennett (2005), 89f. 
or engaging in (within-)case study analysis "is a matter of detective work and historical analysis rather than a matter of applying an orthodox quasi-experimental design" (Ibid., 90). This implies evaluating the (within-)cases through the

various kinds of evidence that may be available; using multiple weak inferences rather than single strong inferences to buttress conclusions; developing procedures for searching through large masses of data when the objectives of the search are not easily summarized by a few simple search rules.

(Ibid., 90)

The method employed is important to phase two. Obviously, one methodological approach is the (within-)case study design, which employs such methods as process-tracing. This dissertation investigates the period from 2009 to 2015; for processtracing in this part more recent (government) sources are useful; on the other hand, on specific analysis within the theoretical framework and relating the current grand strategy manifestations to ancient past, historical literature is more useful for process-tracing. Naturally, process tracing is just one of many available methods in the social sciences but the argument speaking expressly for the use of process tracing in combination with withincase studies is that "mainstream inferential tools used, for example, in classical statistical analysis and comparative cross-case methods cannot be used to make within-case inferences about causal mechanisms" (Beach and Pedersen 2013, 69). 
In the seventh and last chapter of the dissertation-the conclusion-, implications are drawn from the case findings for the sake of theory, which is phase three of this research strategy. As explained above, an investigation in China's grand strategy contradictions "can uncover new or omitted variables, hypotheses, causal paths, causal mechanisms, types, or interaction effects" (Ibid., 109). What concerns the findings, which are relevant to phase three, they may be divided into three categories:

First, they may establish, strengthen, or weaken historical explanations of a case. This is where within-case methods like process-tracing come into play. (...) Second, and more generally, the finding that a theory does or does not explain a case may be generalized to the type or class of cases (...) of which this case is a member. (...) Third, and most broadly, case study findings may in some circumstances be generalized to neighboring cells in a typology, to the role of a particular variable in dissimilar cases, or even to all cases of a phenomenon.

(Ibid., 90) 


\section{HISTORICAL EXPERIENCE AND THEORETICAL FRAMEWORK ${ }^{27}$}

Longer-term, many [Chinese nationalists] aspire to a loose recreation of the tributary system, where regional powers are so dependent on Beijing or intimidated by it that they're rendered submissive.

(Smith 2015a)

As China becomes, again, the world's largest economy, it wants the respect it enjoyed in centuries past. But it does not know how to achieve or deserve.

(Economist 2014)

In an effort to develop the theoretical framework and operationalization thereof, some background knowledge of the Chinese case first needs to be highlighted, especially with respect to an allegedly 'missing' leading ideology of its grand strategy. Second, the cultural driver of 'honor' is traced through the Chinese historical experience, especially in relation to the main vehicle for international relations in China's imperial history, the tributary system. Third, the concepts of grand strategy and grand strategy

\footnotetext{
${ }^{27}$ Parts of this chapter were presented as papers at the 57th Annual Convention of the International Studies Association, Atlanta, Georgia, March 16-19, 2016, at the 57th Annual Meeting of the American Association for Chinese Studies, Houston, Texas, October 9-11, 2015, and at the ECPR Annual Conference, Montréal, Canada, August 28-30, 2015.
} 
design internal incoherence is defined. Fourth, the concept of grand strategy is expanded with the cultural driver of honor, and thereby adjusted to the Chinese case to arrive at a cultural explanation of the incoherence in grand strategy design since the year 2009.

\section{Background: A Missing Leading Ideology for China's Grand Strategy?}

\section{Chinese civilization developed separately from the West for most of its}

existence. China, therefore, operated in a regional state system that was defined by its own standards. Its historical grand strategy was led by its homegrown state ideology of Confucianism, with some administrative features of Legalism. ${ }^{28}$ This, of course, came to an end with China being forced to join the expanding Western-led international society in

${ }^{28}$ Generally, it is accepted among most sinologists, that Legalism was made state ideology by the first Chinese emperor, Qin Shi Huangdi, who united the quarreling Chinese kingdoms under one empire led by the Qin dynasty for the first time in the third century B.C. After the downfall of the Qin dynasty, the Han dynasty set up Confucianism as state ideology, however, still keeping some Legalistic elements, especially concerning the administration of the state, which was centralized with a meritocratic system including official state examinations. Hok-lam Chan calls it an amalgam of a multitude of different philosophical currents, including Confucianism, Legalism, Daoism, cosmological ideas, etc. (Chan 1984). These official state examinations were based on testing the soon-to-be officials on their knowledge of the Confucian classics which they had to be able to recite by heart. This, beginning from the third and second centuries B.C., already resembled many features of the modern state, as we know it now. Because of the centralized rule in Chinahaving united the singular kingdoms under one empire - we can talk about a "state," or "country" of China. China was a united, centralized empire from the third century B.C. to the second century A.D., and-after a temporary split into multiple kingdoms - again from the late sixth century A.D. to today (if one accepts the Chinese dynasties under Mongol and Manchu rule as having represented the "state" of China, which this dissertation certainly does. The author realizes that historians may have an issue with seeing "China" under Mongol and/or Manchu rule as the "state of China" but - from the International Relations theoretical perspective that the concept of grand strategy is closest related to, i.e., Realism, the state is a unitary actor, for the analysis concerning its international relations it does not matter who it is ruled by.). Despite referring to China as a "state" here, it is sometimes said to have the extents of a continent because of its impressive size; today, it certainly is a pan-ethnic, modern state. 
the aftermath of losing to Britain in the First Opium War (1839-42). After the fall of the last imperial dynasty in 1911, specifically Chinese variations of republicanism, socialism, and communism were being developed to replace the Confucian state ideology, the latter of which was inherently associated with the fallen, and undemocratic (and to many Han Chinese, foreign) Manchu-ruled Great Qing dynasty (1644-1911). China had been in decline relative to the Western great powers - and later Japan-during much of the nineteenth and early- to mid-twentieth century. There were attempts to reform and rescue Confucianism as the leading ideology, but they failed; Kang Youwei (1858-1927) and Liang Qichao (1873-1929) were important spearheads of the most famous attempt to reform China's official state ideology, the "Hundred Days Reform" of $1898 .^{29}$

The end of the Great Qing dynasty in 1911 also marked the simultaneous end of the Chinese tributary system; i.e., the way that China managed its international relations in an international society that was inherently legitimized with Confucianism as well. Also, many blamed Confucianism as being the outdated culprit for the decline of China; "[f]or most of the twentieth century the majority of the Chinese [ ... ] see Confucianism as politically conservative and culturally backward" (Yao 2000, 126). Certainly after power fell into the hands of the Republicans in 1912 and later the Communists in 1949 , the new rulers were unlikely to rely on the same ideology that was

\footnotetext{
${ }^{29}$ Other notable scholars who were pro-reform were Liao Ping (1852-1932), or Tan Citong (1865-1898). See, e.g., Yao $(2000,250)$. Max Weber famously "argued that Confucianism was backward looking and too contemptuous of trade and commerce to spur economic activity in a way similar to the Protestant ethic in the West" (Leonard 2005, 516).
} 
credited with the decline and humiliation by the West and Japan that had ultimately led to the overthrow of the Great Qing. In this way, Confucian state ideology had already been replaced in 1912 and 1949 with nationalism and communism ("with Chinese characteristics") respectively. Nevertheless, the Cultural Revolution (1966 to 1976) on the mainland marked the definite end of Confucianism as a framework for state legitimacy or leading ideology in the international relationships. ${ }^{30}$

Even though the Chinese political elites had developed these aforementioned versions of ideologies that originated in the West-i.e., nationalism, socialism, and communism - they still remained distinct from the Judeo-Christian civilization and, especially with the recent strengthening of power capabilities within China and its growth relative to the West, struggled to accept playing only a minor role in a U.S.- and Europeled international society.

Nevertheless, China embraced and joined the capitalist camp by increasing "liberalization" of its own economy starting with Deng Xiaoping's tenure (1978-1992) and later becoming a member of the World Trade Organization (WTO) in 2001. Socialism with Chinese characteristics was de facto delegitimized as a leading ideology for China's international interactions with the economic development of the Chinese mainland. In this ideological vacuum, "Han nationalism" in particular has become the aspiring successor to

\footnotetext{
${ }^{30}$ For some time after 1911 and 1949 , Confucianism was still widely present, and scholars wrote about similarities between Confucian philosophy and Communist ideology; see, e.g., Lee (1973), or Levenson (1962).
} 
Chinese socialism. That is, the Han brand of nationalism is that of the largest ethnic group in mainland China, making up over ninety percent of its population. Confucianism was allowed to flourish again simultaneously with the liberalizations in the late 1970s, but based on the absence of a clear link, one cannot argue that it is seriously informing current Chinese grand strategy.

Today, the Chinese Communist Party (CCP) is trying to legitimize its rule by every means possible, be it economic development, nationalism, or the publicly announced permission for Confucianism to grow freely again, at least as a religion. A recent example of the political use of Confucianism may be the naming of the Chinese equivalent of the German "Goethe Institut" or Spanish "Instituto Cervantes" as "Confucius Institute," or the (temporary) placement of a Confucius Statue in the very symbolic Square of Heavenly Peace (Tian'anmen Square) ${ }^{31}$ In recent speeches, Xi Jinping has based some of his rhetoric quite openly on Chinese philosophical classics, especially a number of Confucian and Legalist texts.

Despite the official absence of ancient ethos and state ideology at first sight, China's grand strategy and international behavior does not clearly fit the mold prescribed

\footnotetext{
${ }^{31}$ For the Confucian revival in China since the late 1970s, see, for example, Fan (2011), Billioud and Thoraval (2009), Ho (2009), Bell (2008), or Weggel (1997). The fact that Confucianism is not present-day China's official state ideology is not to say that there are no scholars that call for more or gradual incorporation of or total adherence to a reformed, adjusted-to-modernity Confucianism in China's political system and international relations, e.g., Qing (2013), Yan (2011), Yu (2009), Zhou (2003), Bell (2007), Bell (2006), and Bell and Ham (2003).
} 
by Western-type grand strategy theory. In other words, China is a hard case for the application of traditional 'Eurocentric' grand strategy theory. This dissertation is an investigation of how China's past, its historically conveyed and cultural understandings of most importantly honor (status/prestige/recognition/reputation) do or do not inform China's current grand strategy design policy inputs. Are the internal contradictions in China's practical and intellectual grand strategy formulations and manifestations due to the "stickiness" of the imperial Chinese mentality, mindset, and philosophical concepts based on the theoretical framework of honor in pursuit of status, prestige, reputation, and recognition $?^{32}$

\section{Tracing the Cultural Drivers in China's History: Honor, Interest, and Fear}

This part of the chapter traces the meanings of the cultural drivers of honor, and less importantly also interest and fear in Chinese culture and history. Lebow relied for his explanation on Western philosophers. Whereas the present study does not seek to significantly change the logic of Lebow's argument, it still wants to add on Chinese history and culture to come to a potentially more nuanced conclusion for the Chinese case.

\footnotetext{
${ }^{32}$ If one believes $\mathrm{Pu}$ (2012) and Connolly and Gottwald (2013), the most important cultural driver should be "honor" for the Chinese case, since China in pre-modern and early modern times was an honor-based society. Lebow concedes that "appetite/interest" and "fear" have become more relevant during modern times, but that most International Relations theories underestimate the individual driver of "honor."
} 


\section{Honor and the Search for Prestige, Status, Reputation, and Recognition}

Relating the definition of honor back to the ancient Greeks, Lebow explains

that

[h]onor refers to the seemingly universal desire to stand out among one's peers, which is often achieved by selfless, sometimes even sacrificial, adherence to social norms. Homer might be considered the first theorist of honor, and his account in the Iliad is unrivaled in its understanding of this motive and its consequences, beneficial and destructive, for societies that make it a central value. In modern times, the needs for status and esteem is described as 'vanity' by Hobbes and Smith, and for Rousseau it is at the core of amour propre.

Lebow further argues that honor draws on the universal drive of "spirit" and refers to the famous explanation given by Thucydides in his account of the Peloponnesian Wars, who attributed the reasons for the conflict to all three drivers of fear, interest, and honor $(2009,5)$. Lebow "contend[s] that each of these motives gives rise to a particular kind of hierarchy, two of which-interest and honor-rest on distinct and different principles of justice" (2009, 5f.). Lebow goes on: 
All three motives also generate different logics concerning cooperation, conflict, and risk-taking. These logics are intended to sustain the orders in question, although, depending on the circumstances, they can also work to undermine them. The dynamic holds true at every level of social order, and the nature of hierarchies and their degree of robustness at any level has important implications for adjacent levels.

Lebow's explanation for the disappearance of honor and, relatedly, spirit as a valid basis for state behavior is the Enlightenment in Europe and the general arrival of modernity: "Moderns rejected the spirit altogether, largely because of its association with the aristocracy. They upgraded appetite, reconceiving it as the source of economic growth and political order. Reason was reduced to a mere instrumentality" $(2009,15) .{ }^{33}$ As a consequence of this development,

[c]onventional paradigms of politics and international relations are rooted in appetite. Liberalism and Marxism describe politics as driven by material interests, and realism acknowledges their primacy after security. [ ... ] Constructivism recognizes that culture and ideology do more than offer rationalizations for behavior that actors engage in for other reasons. [ ... ]

\footnotetext{
33 "Reason" is used as another cultural drive; however, the present study does not find this relevant to the Chinese case. "Habit" is another motive in international politics that Lebow mentions at times, which also will not play a significant role in this study other than for the "path-dependency" component of my argument.
} 
Just as the drive for wealth and security inform international relations theory, so too must the drive for self-esteem.

(Lebow 2009, 15f.)

Lebow's explanation is obviously meant to be applicable universally to all cultures throughout all times and places, or else he would not claim to be producing a "grand theory" of international relations. However, in order to adjust this to the Chinese case and avoid the risk of and relying on a 'Eurocentric' theory that may not yield robust results for the present case, honor, the 'universal' drive of spirit, and the end of status, recognition, and prestige is examined on the basis of Chinese history-i.e., Chinese historical sources of both a normative (philosophical) and governmental (historiographical) nature.

Looking at the modern translation of prestige, an end that honor/spirit supposedly aims to achieve, Hans van Ess explains its meaning and etymology:

There are three translations [of the Western word 'prestige' into Chinese], namely 1) ‘wei-wang’ 威望, 2) ‘wei-hsin’ 威信 and 3) 'sheng-wang’ 声望. The singular signs that make up these words are perhaps of some interest: 'wei' means 'awe-inspiring' and 'awing,' respectively, 'grandeur,' 'power,' and 'majesty.' It is a word which was used in early imperial China almost exclusively in connection with the Emperor personally, or his dynasty, although it was used for some high-ranking figures to call them 'powerful.' 
The opposite of Wei 'to have fear' is, by the way, also 'wei,' but it is read in the fourth tone and should have originated from the word for power. To inspire awe and fear seems to be a basic condition for 'prestige' according to Chinese understanding. 'Wang' means to 'be on the lookout,' and 'look up' in the second tone. Modernly the first combination is defined with the terms 'sheng-wei' 声威 for 'reputation' and 'ming-wang' 名望 for the 'good reputation.'

(van Ess 2013, 35; own translation)

Van Ess concludes from this that in modern China, prestige means the same as authority-inspiring $(2013,35)$. Furthermore, the important term of “te” 德 with regard to prestige is explained at length by van Ess:

A central term of the old thinking, which can only be found popularly in idioms nowadays, is that of 'potency' and 'charisma,' which is often translated in European literature with 'virtue.' This term, 'te' 德, can be found in a great many of ancient Chinese sources. It is one of the main goals of philosophical instruction of ancient China, to teach the student as much 'te' as possible. What the term means specifically, is-like with all old, abstract terms - hard to grasp. In any case, the ability to draw others toward oneself plays an important role. There are different ways to do this. Often the use of 'te' is connected to financial means, as can be seen with an 
example: There was a noble family that was building up its power position through the use of 'secret te.' What is meant by this is apparently that they were financing the poor and needy. The growth of own 'te,' which results from this, leads eventually to the surpassing of the ruling house by this noble family in the state that they live in, therefore eventual usurpation. It is also said that the ancestors of dynasties normally accumulated 'te' over generations before they took power. Only when there was enough 'te' at hand, could one's own dynasty be founded. What is decisive, though, in the Confucian philosophy, which later establishes itself, is the moral component- 'te' does not simply mean, whoever is noble or has enough financial means, but who can achieve reputation through a convincing way of life. The material is often subordinated to the ideal aspect. It can either be wholly absent, or come as a result of the ideal.

(van Ess 2013, 36; own translation)

As is evident from this analysis of the Chinese term 'te,' Chinese culture puts a great emphasis on its ideal, intangible, moral aspects in order to attain prestige, and status and recognition along with that prestige. 'Te' may be seen as a sort of honor code that needed to be followed closely in order to accumulate the necessary prestige. In that sense, this served to legitimize the rule of the imperial family or of the nobility that sought to overthrow them. That link of legitimacy to the cultural drive of honor to attain prestige, status, and recognition is key to understanding political actions in both ancient and modern China. This refers to "semantic legitimation [which] involves the articulation and 
invocation of extraordinary signs of a predominantly symbolic character indicative of the command of legitimate authority" (Chan 1984, 17), as well as "scholastic legitimation [which] involves the articulation and manipulation by the ruler or his agents of the concepts from the predominant religious, intellectual, and political traditions to confirm his claim to the mandate" (Chan 1984, 17).

Besides attaining prestige, which is the predominant purpose of the cultural drive of honor, there are also status and recognition. These latter two are different, though, in the sense that they have to be seen as relational. ${ }^{34}$ Following Kang, "status is an inherently relational concept and manifests itself hierarchically" (Kang 2010, 19). Recognition is where legitimacy comes into play, since on the international level smaller states need to recognize a super- or great power's status through different ways of showing this recognition like following the great power's lead, joining it in an alliance, submitting itself to its power, and similar endeavors.

To relate honor and the attainment of prestige, status, and recognition to the tributary system is very simple, given the etymology of the term. In this institutionalized system in which China managed its international affairs, the participating regional statelike entities were invited by the Emperor to travel to the imperial capital and offer their tribute to him, thereby honoring him, giving him prestige, and accepting and recognizing the Chinese Emperor's unchallenged highest status among Asian rulers. Status played an

\footnotetext{
${ }^{34}$ See, for example, Kang (2010), 17-24.
} 
important role in the tributary system, as a state's status was more or less determined by its degree of cultural similarity to China. Korea was the so-called model tributary state, as it assimilated much of the Chinese example. The status was then reflected in the frequency of that state being "allowed" to visit the Chinese Emperor in the capital. As the Chinese state was master of this hierarchy and other states' statuses, it naturally was at the top by default.

In the same vein, material factors such as military, financial, and economic power are downgraded and seen as mere consequences of having good 'te' rather than the opposite. This shows that Lebow's argument that honor as a cultural drive is superior to that of interest or fear also holds true for the Chinese case.

\section{(Economic) Interest and the Search for Wealth}

As explained above, Lebow relates (economic) interest to the "universal" drive of "appetite." The end of this drive is the general search for wealth. As an explanation for international politics, this cultural drive came to the fore together with the Enlightenment in Europe to replace honor and spirit and, as Lebow explains, to take the protagonist role for Liberalism and Marxism later on $(2009,15 f$.).

The definition of 'te', according to Van Ess, contains an economic component, to be sure, but it should be seen more as a consequence of having good 'te' 
than the other way around. Van Ess' example of a usurping, noble family 'buying' support among the poor and needy is a clear example of power politics on the economic level. In the end it is aimed at changing the balance of power, albeit at the local or domestic level, and legitimize one's mandate to rule. And there, finances reinforce one's prestige, as accumulated in 'te.'

With regard to the cultural drive of economic interest within the tributary system, there are a number of scholars that think of the tributary system as having been a marketplace for trade during the imperial age of China, and nothing more. ${ }^{35}$ However, the tributary system's trade balance was in fact a deficient one for the Chinese regional hegemon, since China offered luxury goods like silk, porcelain, tea, spices, and the like, often in return for simpler, no value-added goods like horses or fur (from the Turkic nomads, for example). The fact remains, though, that it offered China leverage over the participating state-like entities within the tributary system, and in the end also benefitted from this trade, since it helped promote regional peace.

The very fact that within the tributary system China was suffering a balanceof-trade deficit is important here, insofar as it supports the above postulation that honor is more important than material aspects like economic or military capabilities. China was using the tributary system for its internal and external legitimacy and, related to that, its standing, recognition, and prestige, and thus accepted the need for spending its economic

${ }^{35}$ See Kang (2010), $11 \mathrm{f}$. 
and financial assets on buying off its neighbors in order to accumulate 'te' from them as well as its own population.

\section{Fear and the Search for Security}

Fear and security were insofar always present in Chinese history and the tributary system, since the Turkic nomads in the North and West of the Chinese heartland did not fall prey to cultural assimilation. China thus did not really have any power over their behavior, and they would raid the frontier regions as they pleased. David Kang builds a valid argument around the fact that the Turkic nomads did not settle, and therefore cannot be seen as a state-like entity - at least one with a central administration, institutions, and so on. ${ }^{36}$ That is why, according to Kang, this region is better designated as a 'frontier' rather than a 'border,' and, essentially, why there were many skirmishes over the centuries between the nomads and the settled Chinese.

Nevertheless, that fear of the nomads — be it the Xiongnu during Han times, or the Jurchen, Mongols, or Manchus in early modern imperial China-was the drive that had as its end security (and survival). This fear was reinforced by the Mongols having successfully conquered and ruled Chinese territory during the Yuan dynasty, and after the Ming dynasty, again another nomadic group, the Manchus.

${ }^{36}$ See Kang (2010), 139-157. 
Tracing the importance of security-related fear in the history of the tributary system, based on the premise that all states in it accepted the cultural and civilizational primacy of China, as well as its status as hegemon, based as described above on the Ming (and then Qing) being the successors to the powerful Yuan. The status as hegemon also resulted from the impressive size and the capabilities that China had in abundance compared to Korea and Japan, which made them seem almost predestined to be junior partners and no more. Given that Korea and Japan were merely junior partners in this institutionalized hegemon-ruled international society, "based on Chinese cultural superiority and military suzerainty, the non-Chinese states were expected to accept Chinese ideas and institutions" (Yun 1998, 2).

As we see from the description of prestige as awe- or fear-inspiring above, it is almost impossible to separate these cultural drives entirely. Following this, it would mean that they positively reinforce each other; i.e., that to attain prestige in China, to inspire fear in others (and perhaps even its own population) was necessary. Fear in conjunction with the wielding of military power is then conducive to attaining "coercive legitimation [which] pertains to legitimation that is either introduced, captured, or maintained by the use of force" (Chan 1984, 17). 


\section{The Tributary System, Historical Memory, and the Century of Humiliation}

\section{Honor, Legitimacy, and the Tributary System ${ }^{37}$}

Without doubt, honor is a cultural driver of the utmost importance in China's long history. The concepts of losing face and giving face just stand as an example for such an honor-based society as China's. ${ }^{38}$ This is not to say that the cultural drivers of economic interest and fear did not play a role at all; they have played and continue to play a role. But as the above analysis showed, honor may have a disproportionally high importance attached to it in China's case, especially in terms of international relations within the tributary system.

Looking at the institutional setup of China's tributary system and the rites involved in it, as well as the underlying Confucian ideology, the cultural driver of honor is the centerpiece. With the end of searching for prestige, status, recognition, and reputation, honor played a major role in the tributary system. First, as many analyses have confirmed, ${ }^{39}$ hierarchy (rather than the western concept of anarchy, which the modern Westphalian international society was and is based on) is the ordering principle within the tributary

\footnotetext{
${ }^{37}$ Parts of this chapter were previously presented at the 2013 Joint Conference of the International Forum for Contemporary Chinese Studies and the British Associations for Chinese, Japanese, and Korean Studies at Nottingham University, September 5-7, 2013, and at the 55 ${ }^{\text {th }}$ Annual Meeting of the Association for Chinese Studies at Rutgers University, October 11-13, 2013.

${ }^{38}$ See, e.g., Ding and Xu (2015).

${ }^{39}$ See, e.g., Kang (2010) or Kang (2003).
} 
system, as status is deeply ingrained in this institution because of Confucian ideological influence. As it was set up, the Chinese empire was at the top of this hierarchical construct. The states and nomadic ethnic groups surrounding the Chinese empire, which were its tributaries, were then ranked in a hierarchical order. This was usually based on how well the state or ethnic group in question was able to imitate the Chinese model with Chinese culture, especially its Confucian state ideology. For the most part, Korea was usually second to China in the tributary hierarchical order. The rank in which a tributary was placed, of course, was not published by the state authorities but rather it manifested itself subtly in the cycle in which that tributary was 'allowed' to visit the emperor in Beijing, or whatever the capital was in the particular dynastic time period. ${ }^{40}$ Status as the goal of the cultural factor of honor is more than obvious in this instance.

Second, internally, China sought recognition and reputation enhancement from the surrounding states and ethnic groups through the tributary system as, inherent in the tributary system and its name, they would come to the emperor and perform rites in recognition of the Chinese empire's dominance and geopolitical influence. The koutou is perhaps the most well-known and metaphorically meaningful rite involved with such a ceremonial visit of a tributary: The delegate of the foreign royal, chief, or spiritual leader would have to kneel down to the ground and touch it with his forehead three times.

\footnotetext{
${ }^{40}$ The capital was never a constant in Chinese history. For the last five dynasties, the last imperial capital was Beiping, today's Beijing, during the Qing dynasty under Manchu rule. In the Yuan dynasty under Mongol rule, it was referred to as Khanbalik. During the Tang, Song, and Ming dynasties, there were two capitals (either chronologically one after the other, or synchronously with different administrative regional tasks), Chang'an and Luoyang, Bianjing and Lin'an, and Beijing and Nanjing, respectively.
} 
Practically, this rite showed the subjugation of the state or nomadic group whom the particular delegation represented. As the Chinese empire was obviously not a parliamentary monarchy but more of a hereditary authoritarian yet bureaucratically meritocratic (and therefore said to be 'modern') monarchic state, the legitimacy of imperial rule was achieved not with elections but with, among other things, the tributary system. International relations were therefore also critically important for domestic politics in imperial China. The Chinese government sought prestige externally for its own internal legitimization, i.e., legitimizing its state ideology by way of subtly imposing it on others as well, and by having quasi-vassal states acknowledge this prestige through tributary delegations to its own population. ${ }^{41}$ An example of this may be the relationship of Ming China to the Goryeo Korea right after the setup of the Ming Dynasty in an effort to establish legitimacy quickly:

The early Ming Dynasty sought a quick tributary relationship with the then Korean Goryeo Dynasty (918-1392) with the purpose of strengthening the legitimacy of both sides and deterring the Mongolians from striking back (...). In other words, the tribute system was a form of alliance.

(Shih 2012, 26; quoted and translated from Chung 2006)

\footnotetext{
${ }^{41}$ It is historically unclear whether China actually colonized surrounding states via the tributary system and exerted suzerainty over them, or whether the tributary system was merely an economic exchange of goods in which the display of submission and the status of China as supreme and the others ranking below it are merely symbolic gestures.
} 
The fact that all these tributaries regarded the Chinese state ideology as ingrained in the tributary system so highly and bowed before the emperor gave the imperial family and administration prestige, recognition, and reputation, which translated to legitimacy vis-avis its own domestic population. Because of this, honor, and with it prestige and reputation on the international level, is historically intrinsically important to domestic rule in China.

Third, externally, China also gave status, prestige, reputation and recognition to the tributaries through this system. For example and most significantly, they bestowed royal titles on the leaders of the tributaries. In the following instance, China did use power political sanctioning by the

suspension of trade [which resulted in] that the Altan Khan[, the Mongol leader,] persisted in raiding Chinese border areas until a settlement was reached in 1571. Disorder along the frontiers harmed both the Ming, who expended vast sums for defense, and the Mongols, who were weary of the constant warfare. [To appease the Mongols, $t$ ]rade markets were permitted on the frontiers (...). The court also granted the Altan Khan the title 'Shuni wang' (obedient and righteous prince) (...). This agreement, which permitted a flow of tribute and trade from the Mongols, (...) reduced much of the turbulence along the Sino-Mongol border.

(Twitchett and Fairbank 1978, 237) 
While requiring them to more or less adopt Confucian ideology in a subtle way, the Chinese also gave their neighbors a powerful state ideology that they could use to legitimize their own rule at home and hierarchically organize their societies. Here, legitimacy plays a role as well, not just for the tributaries, which were of course eager to use Chinese state ideology in their own countries. The Chinese state ideology was legitimized to them and their populations because the Chinese were regarded as the most advanced civilization known to mankind in Asia, and their prowess was proof that this system and ideology had led them to achieve a great deal as the regional hegemon. ${ }^{42}$

This third argument regarding the relationship between legitimacy, honor, and tributary relations can even be taken further. For China, state legitimacy heavily relied on the tributary system, and even though the tributary system institutionalized the hegemony of China over much of East Asia and put other states under suzerainty, China was actually — despite the fact that the distribution of capabilities were by far in China's favor - acting quite sensibly in terms of appreciating the 'junior partner' states, Korea and Japan, as well as the Turkic nomads to its North and West. Kang mistakenly reads from literature relying on Chinese sources that "a key element of the tribute system was the explicitly unequal nature of the relationship" (Kang 2010, 57). This is so because for

\footnotetext{
${ }^{42}$ The fact that parliamentary monarchy and Western liberal democracy became en vogue with the global hegemonies of Great Britain and the United States, respectively, may be an analogy that comes to mind instantly when talking about other states adopting the Confucian state ideology during medieval times from the Chinese (regional) hegemon. In the same way, a parliament and elections gave more legitimacy to modern nation-states in the West, as the Confucian state ideology has more legitimacy for states or state-like entities in the East.
} 
domestic purposes the Chinese used a "carefully chosen vocabulary (...) to suggest Chinese superiority" (Yun 1998, 2). But outside of the domestic Chinese arena this was perceived differently, because the Chinese did not talk to their neighbors condescendingly; for example, "the Mongol tribes often 'thought of the tribute system as a tribute paid to them"' (Yun 1998, 3; partial quote from Serruys 1967, 21). And at times Korea saw its relationship with China as being on an equal footing. ${ }^{43}$ So, even though China was aware of its hegemonic status, they only employed it domestically for prestige; for example, through historiographical dynasty histories. But in China's position in the tributary system, there was some leeway for great power management, as happened concerning the management of relations between Korea and Japan: "the identical status assigned to the rulers of Yi Korea and Ashikaga Japan under the Ming tribute system seems to have facilitated the establishment of formal relations between the two neighbors on the basis of "equality"' (Kim 1980, 15; also quoted in Kang 2010, 60). So China was able to reinforce the creation of an international society through their hegemonic position in the tributary system. Korea similarly made use of the tributary system:

When the system centered on the Sinic court, the peninsula regimes practiced on relying on the tribute system to deter the invasion by the nonHan forces. To this extent, the tribute system was neither cultural nor economic as the Chinese or English literature would have its readers believe.

${ }^{43}$ See Shih 2012. 
For the peninsular kingdom, their participation in the tribute system was predominantly out of political motivation.

(Shih 2012, 24; quoted from Chun 1968)

Thus one can contend that besides the obvious economic and military importance of the tributary system, it was also quite important politically for strategy and legitimacy while saving the other party's face.

\section{Honor, Legitimacy, and China in the Modern Westphalian International Society}

With the Chinese empire's decline starting in the early nineteenth century, it was easy prey for the Western great powers, later joined by Japan. The First Opium War in the late 1830s between China and the United Kingdom rang in the so-called one hundred years of humiliation, ${ }^{44}$ in which a series of wars and imposed treaties, usually ending conflicts that China lost to a European power or Japan, followed. They stipulated high reparations for China to pay and often also forced China to leave its isolationist stance and open itself to trade with the Europeans in specified harbor cities assigned to certain powers, e.g., Hong Kong to Great Britain. The First Sino-Japanese War in 1894-1895, in which China suffered a rather quick naval defeat, which resulted in the Treaty of Shimonoseki (Treaty of Maguan in Chinese) and the eventual colonization of Manchuria by Japan, which

\footnotetext{
${ }^{44}$ Besides this term, this period is sometimes referred to as Century of (National) Humiliation, or Hundred Years of (National) Humiliation. See, e.g., Wang (2012).
} 
together with a German colony in Shandong and the British crown colony in Hong Kong were major humiliations to the Chinese empire. After the monarchy was driven out and the Chinese Republic had been established in 1911 and 1912, respectively, another period of chaos ensued for China with warlords controlling some areas of its territory and the struggle between the Republican and Communist factions later more or less enabling conquest by Japan, especially of the eastern Chinese seaboard. The 'century of humiliation' then ended, depending on how one defines it, with China driving the Japanese out of the mainland in 1945, or with the end of the Chinese Civil War, which followed the Second World War in China in 1949.

This 'century of humiliation' has left deep marks in the Chinese psyche. It has created a type of victim mentality, and perhaps even a conditioned aversion to interaction with the West in general. During this 'century of humiliation,' China had to give up its tributary system of conducting international relations and open itself to international society while slowly getting used to Western-based norms, like the fundamental cornerstone of the modern Westphalian international society of state sovereignty.

For China, this experience of the 'century of humiliation' and how it became part of political rhetoric led to the development of a victim ideology. In a sense, the humiliating actions of the Western powers and Japan were utilized by successive postimperial Chinese leaderships to unite (or attempt to unite) the multitude of ethnicities in 
China's territory into a nation. ${ }^{45}$ Sun Yat-sen, the Republican founding father of China, had the vision of a multi-ethnic China in one republic. Under Mao Zedong, class was the uniting factor among the ethnicities. Nevertheless, the 'century of humiliation,' even after it ended, was an important part of Chinese political rhetoric and continues to play a part in China's international relations today. For example, in the white paper on China's PD, it appears in the fourth paragraph:

In the mid-19th century, Western powers forced open China's door with gunboats. Internal turmoil and foreign aggression gradually turned China into a semi-colonial and semi-feudal society. The country became poor and weak, and the people suffered from wars and chaos. Facing imminent danger of national subjugation, one generation of patriots after another fought hard to find a way to reform and save the nation. The Revolution of 1911 put an end to the system of monarchy which had ruled China for several thousand years, and inspired the Chinese people to struggle for independence and prosperity. However, such efforts and struggle failed to change the nature of China as a semi-colonial and semi-feudal society, or lift the Chinese people out of misery. Living up to the people's expectation, the CPC led them in carrying out arduous struggle, and finally founded the

\footnotetext{
${ }^{45}$ To qualify this, especially what concerns Japan, some Chinese leaders have had favorable—or at least not antagonistic - views of Japan during some time periods. At times, Japan was seen as an East Asian fraternal nation with which China should cooperate. Sun Yat-sen held this view, but also Mao Zedong initially. Still, nowadays the relationship with Japan is mostly antagonistic, particularly what concerns politics and societal relations.
} 
People's Republic of China in 1949. This marked the realization of China's independence and liberation of its people and ushered in a new epoch in China's history.

(China 2011)

It becomes more or less clear from this white paper excerpt that in one way or another China has developed a kind of complex centering on this experienced humiliation that has not been overcome and instead became a part of China's political culture. Certainly the mere mention in a white paper on the general international policy for the twenty-first century is proof that China is dwelling on this traumatic episode of the nineteenth and twentieth centuries. Many scholars agree with this viewpoint, as Zhu Zhiqun writes:

To understand China's foreign policy today, one has to understand the socalled 'century of humiliation' in Chinese history. This refers to the roughly one hundred-year period from 1839 to 1949 , during which China was humiliated by and suffered from Western and Japanese domination. (...) China essentially became a semi-colony of major Western powers and Japan. (...) This 'century of humiliation' continues to have a profound impact on China's foreign relations today. The PRC considers itself a country whose historical greatness was eclipsed by Western and Japanese imperialist aggression. Chinese leaders and the public today are often reminded that only the $\mathrm{CCP}$ was able to 'save China' and end the 'century of humiliation.' For the Chinese, Hong Kong and Taiwan bring back 
memories of past sufferings and foreign bullying. Knowing this history helps to explain why the Chinese are obsessed with issues regarding sovereignty, national unification, and territorial integrity. As China becomes more powerful, nationalism will continue to grow when foreign countries, especially those former 'invaders and colonizers,' are perceived to be encroaching on China's sovereignty—such as supporting independence for Taiwan or Tibet. No matter how its foreign policies may change, China considers several 'core interests' to be inviolable, especially those concerning Taiwan and Tibet.

(Zhu 2013, 119f.)

Besides the development of a victim ideology, China may be said to have also developed a sort of conditioned aversion to Western norms and the West in general, along with its arch-enemy Japan. This would explain why sometimes, situationally, China does not act like a rational actor, too. This aversion stems, of course, from the humiliation of the conquest and colonization of China, the violation of China's sovereignty and territorial integrity. Nowadays we witness a China that has been obsessed for decades with enforcing its territorial integrity very strictly. One example is the fact that China will not engage in foreign relations with a country that does not accept Tibet and Taiwan as inherent parts of China's territory. Also, in its engagements with other nations China holds noninterference in its internal affairs to be of very high importance. In short, the consequence of the 'century of humiliation' was that China became obsessed with sovereignty, non- 
interference in internal affairs, and territorial integrity; i.e., whatever it felt it had suffered at the hands of the Western powers and Japan.

In all this, it is implied that with the term and concept of the 'century of humiliation,' China has had to endure a fatal blow to its status as the regional hegemon in Asia. Along with the loss of status, it also obviously lost reputation, recognition, and prestige. The 'century of humiliation' was an attack on China's honor, especially the honor it had been able to project with its international prestige and status. This was clearly missing after China was forced to open up and become part of the existing Western-based international society, and the ensuing demise of the tributary relations China had used to gain prestige since centuries. China suddenly saw itself humiliated and without an 'outlet' for its international relations in terms of honor, which, as discussed above, is inherently connected to external and internal legitimacy throughout China's history. China found itself in a kind of legitimacy and honor vacuum.

\section{Honor, Legitimacy, Historical Memory and Culture as a Constant?}

Even though China was a victim of over a hundred years of colonization and forced opening, it still places high emphasis on honor as a cultural drive toward prestige, recognition, status, and reputation. The main outlet for this, the tributary system, has not existed since the fall of the last Chinese dynasty, but it is still observably part of Chinese

politics and international relations. Just like humans are creatures of habit, so are states and 
state institutions. For example, for someone who teaches a class in college, it is observable that students will often sit in the same spot that they sat in during the first day of class throughout every single session during the rest of the semester, even though students are theoretically be allowed to sit anywhere they wish. In the same way, firstly, states can have historical memories of past events such as the 'century of humiliation,' which then become part of the political culture of that country. Secondly, institutions may be said to have an institutional historical memory of their own, i.e., that an institution once created for a certain purpose continues in this purpose throughout centuries and across different governments and state forms. Similarly, in addition to the enduring purpose of an institution, a certain institutional political culture may also continue to exist.

On the one hand, China can be said to have an underlying complex acquired by the 'century of humiliation. ${ }^{46}$ As an unwillingly acquired part of its political culture, it has become one of the dictating cultural influences in its post-imperial conduct, especially post-World War Two. Certainly, this impacts the cultural drivers of fear in relation to its

\footnotetext{
${ }^{46}$ Complex may be the best-fitting description for the psychological effect the 'century of humiliation' has on China's general foreign and security policies. Other psychological concepts that are less well fitting are those of trauma, condition, and aversion. If one defines this 'century of humiliation' as something that is only relevant at certain times and is something that is 'triggered' by certain situations, then it should be referred to as aversion. In a way, this remains to be seen until resolution by the following case analyses. Complex, trauma, and condition will refer to a more constant influence on state behavior that is continuous, not situational. Complex may be the most suitable because it refers to the highest constancy, whereas trauma or condition could also equally refer to that, but there may or may not be some situational element, and they have a slightly derogatory ring to them, especially trauma. Hence, I chose complex in reference to the 'century of humiliation's' influence on China's state behavior.
} 
state security and, crucially, of honor in relation to its prestige, status, recognition, and reputation.

On the other hand, China had arranged its imperial international relations for centuries through different dynasties under its self-created tributary system, which institutionalized China's primacy in East Asia, helped advance its Confucian state ideology and assimilate adjacent states thereby, as well as locking this prestigious status in through good and bad economic times. The purpose of the tributary system, as described above, was not to conquer every territory surrounding China but, most importantly, to use it for external and internal legitimacy by giving and receiving status. This institutional political culture, its purpose (legitimacy through prestige) and its processes (symbolic gestures to receive and give status, prestige, recognition, reputation) continue via the national historical memory and institutional historical memory to this day. It is part of China's culture, or cultural driver of honor, and therefore relevant in explaining its grand strategy manifestations.

\section{Conceptual Definitions: Grand Strategy and Grand Strategy Incoherence}

Generally speaking, the theoretical framework operates on the basis of the

theory of grand strategy. In its origin, grand strategy is a fundamentally realist concept, 
functioning according to the assumptions of the international relations theory of realism. ${ }^{47}$ Given the Eurocentrism of this theory of international relations, its later combination with the cultural drivers make it applicable to China's grand strategy. Still, the realist basis is useful because China no longer operates in its own international system, which it dominated and was able to form by its own norms, rules, and values, but rather operates in the modern, so-called Westphalian international system, which is dominated by the United States and the Western great powers.

The realist part of the concept will be kept as is, i.e., that grand strategy serves the state's national interest and has as its end mainly the security and survival of the state, by (in a neorealist understanding) also increasing its economic capabilities, which relates to the cultural drive of interest. However, this drive is combined with the cultural motive of honor and the attendant ends of increasing prestige, standing, and recognition.

\footnotetext{
${ }^{47}$ Defensive and offensive realists see the international system as anarchic. They focus on states that they see as unitary, monolithic actors. This is different from liberal International Relations scholars who see the state as permeable, meaning that interest groups within a state as well as organizational processes are of relevance to them. Realists tend to see the national interest of a state rather than multiple interests of different groups within a state. For realists, the national interest can usually be defined as survival and security of the state for defensive realists, and power maximization for the sake of security for offensive realists. Realists see their grand theory of international relations as universally applicable through time and space, with no need to take culture, values, or the like into account. This may also be due to the theoretical parsimony of realism, i.e., the striving for as few variables as possible to explain or predict something.
} 


\section{The Concept of Grand Strategy}

Originally, Liddell Hart had described grand strategy as the "'higher level' of wartime strategy above the strictly military, by which the nation's policymakers coordinate all of the resources at their disposal - military, economic, diplomatic - toward the political ends of any given war" (Hart 1954, 31; as quoted in Dueck 2006, 9).

Other definitions of grand strategy may be "broad-based policies that a state may adopt for the preservation and enhancement of its security" (Nordlinger 1995, 9-10; as quoted in Dueck 2006, 9), “[a] political-military 'means-ends' chain, a state's theory about how it can best 'cause' security for itself' (Posen 1985, 13; as quoted in Dueck 2006, 9), “[a] state's overall plan for providing national security by keeping national resources and external commitments in balance" (Kupchan 1994, 3n4; as quoted in Dueck 2006, 9), or " $[\mathrm{t}]$ he full package of domestic and international policies designed to increase national power and security" (Christensen 1996, 7; as quoted in Dueck 2006, 10). John Lewis Gaddis defines grand strategy rather broadly as

the calculated relationship of means to large ends. It is how one uses whatever one has to get to wherever it is one wants to go. Our knowledge of grand strategy derives chiefly from the world of war and statecraft because the fighting of wars and the management of states have demanded the calculated relationships between ends and means (...). But grand strategy need not only apply to war and statecraft. Grand strategy is 
potentially applicable to any endeavor in which means must be deployed in the pursuit of important ends.

(Gaddis 2009)

Colin Dueck in Reluctant Crusaders defines grand strategy in a more narrow way, finding that "[i]], for example, it is used to refer to the pursuit of all national ends in international relations by all means, it is difficult to see what distinguishes grand strategy from foreign policy in general" (Dueck 2006, 10; italics added). He argues that if there were no conflict between nations there would be no need for strategy, which is why grand strategy is the "calculated relationship of ends and means, (...) in the face of one or more potential opponents" (Dueck 2006, 10). Dueck's second narrowing of the definition is that military instruments must be seen as more central to grand strategy than economic or diplomatic ones such as "foreign aid, diplomatic activity, even trade policy," because there would be no analysis of grand strategy if there was no possibility of armed conflict (Dueck 2006, 10). Non-military instruments, though, are still "elements of a grand strategy [but] only insofar as they are meant to serve the overall pursuit of national goals in the face of potential armed conflict with potential opponents" (Dueck 2006, 10).

Dueck goes on to explain how grand strategies may change through either culture of a nation; i.e., a state-level explanation, or through changes in the distribution of power on the international level; i.e., focusing on the systemic level of analysis. Dueck adds to this an "alternative 'neoclassical realist' model of strategic adjustment, showing 
how cultural and power-based variables interrelate in the formation of strategic choice" (Dueck 2006, 9).

Overall this is a concept that is mostly employed by Realist schools, but because it incorporates many statecraft tools, the economic aspect of grand strategy makes it attractive to Liberal and Neo-Marxist schools of International Relations as well, as does the cultural aspect to other schools than just Realism. Concerning the longevity and persistence of grand strategy, as Lobell asserts, it "involves long-term planning, over decades and perhaps centuries" $(2003,3)$.

In Sanctions as Grand Strategy, Brendan Taylor shows how major international actors have used sanctions in the cases of North Korea (DPRK) and Iran. First, he identifies three schools of thought regarding sanctions: one concludes that they do not work as an effective tool, another concludes the exact opposite, and a third that thinks of sanctions as symbolic. Taylor concludes that "sanctions scholars have also yet to adequately acknowledge the utility that great power policymakers continue to derive from using these instruments of statecraft for the express purpose of influencing one another in the context of executing and advancing their respective grand-strategic objectives" (Taylor 2010, 109). Besides focusing on the differences in how major international actors used sanctions strategically, his analysis shows that most of the sanctions did not work in the Iran and DPRK cases, which, combined with the above-mentioned conclusion of using sanctions toward achievement of grand strategy, is the so-called "'sanctions paradox': Why 
do policymakers continue to employ [sanctions] despite their outwardly dubious utility in influencing target actor behaviour?" (Taylor 2010, 109).

Christopher Layne argues in an edited volume on Rethinking Realism in International Relations "that with respect to the study of great powers' grand strategies, neorealism (structural realism) and neoclassical realism are complementary-not competing — approaches" (Layne 2009, 103). This is also "because neorealist theory cannot explain why the United States is pursuing a strategy of extraregional hegemony in East Asia" (Layne 2009, 104). Layne thus quotes from Neoclassical Realism, the State, and Foreign Policy that "[o]ver the long term, international political outcomes generally mirror the actual distribution of power among states [, whereas i]n the shorter term, (...) the policies states pursue are rarely objectively efficient or predictable based on a purely systemic analysis" (Lobell, Ripsman, and Taliaferro 2009; as quoted in Layne 2009, 105). The conclusion there is that through “examining great powers' internal decision-making processes and the domestic social, economic, and political constraints on policymakers, neoclassical realism explains why great powers adopt particular grand strategies" (Layne 2009, 105). While Layne's research objective is to analyze U.S. grand strategy toward China rather than that of China itself, he still asserts that China's rise to great power status has

important geopolitical effects[:] First, as [China gains] relative power, [it is] more likely to attempt to advance [its] standing in the international system. Second, [its] growing power fuels [its] geopolitical ambitions, and, as [it] 
seek[s] control over the external environment through expansion, [its] external interests and commitments expand and begin to collide with those of other great powers.

$(2009,115)$

He predicts that, according to balance-of-power theory, strict defensive realism, and offensive realism,

a rising China will build up its military capabilities and-broadly speaking — emulate the United States in its sphere. Balance-of-power theory and offensive realism also predict that China will seek to expand its influence in the international system and to reorder the "hierarchy of prestige' to reflect the changed distribution of power in its favor. Finally, balance-of-power theory and offensive realism predict that the geographical scope of China's political and economic interests will expand and that this will cause a corresponding extension of its geopolitical and military footprint

To apply grand strategy to the Chinese case, therefore, seems quite fitting because "Chinese strategic doctrine tends to draw on a cultural-historical experience that emphasizes patience and thinking in terms of decades, not months or years" (Kay 2015, 111; italics added), which goes hand in hand with Lobell's assertion regarding the long- 
term nature of grand strategy. China has historically been a regional hegemon and great power, and arguably has now reacquired such a status, or at least is in the process of doing so.

Grand strategy is a strategic concept that applies above all to great powers and hegemons, simply because smaller powers do not have the combined capabilities to influence world order according to their wishes. China is such a great power and regional hegemon, which qualifies it for grand strategy application.

Also, smaller powers do not easily decide to wage war against other powers, but being able to wage war is an important aspect of the concept of grand strategy; i.e., that the concept does not apply only to peacetime or only to wartime, but both; it needs to be applied to a power that has credible capabilities with which they can engage in military activities to defend their borders, help defend allies, or use them towards revisionist goals. China has shown that this is the case for itself, having 'defended' its borders against India in the 1960s, for example, or having attacked Vietnam in 1979 for retaliatory purposes, even if the latter expedition backfired. This indicates that China is a power that does not rule out military action, but recently has focused on other competitive areas such as economics, information, and diplomacy while obviously still modernizing their conventional and nuclear military capabilities, with a short-term focus on asymmetric military capabilities. 


\section{Defining 'internal incoherence'}

To be clear, the "internal coherence” of any nation's GS is defined here as "the manner in which different policies within a grand strategy design support or undermine each other" (Papasotiriou 1992, v). A grand strategy design receives policy inputs from diplomacy, military strategy, and economic policy (Ibidem, v). When they pull in different directions - i.e., when the proclaimed grand strategy and the singular policy inputs do not go "hand in glove" but contradict each other - the outcome is grand strategy design incoherence.

The primary example of the internal incoherence of Chinese grand strategy is the fact that the general grand strategy of China as "Peaceful Development/Peaceful Rise" and "Keeping a Low Profile" (sometimes mistakenly translated into English as "Hiding One's Capabilities") contradicts the-apparently now in the making-"Striving for Achievement" grand strategy, or simply put, China's throwing its weight around. Confucianism, which China has used historically as an official state ideology, contradicts the power-political muscle-play of China both today and also in many historic instances.

In terms of Chinese grand strategy, in the period since 2009 we have continuing manifestations of the actual proclaimed grand strategy of PD, as well as increasing manifestations of power politics on the part of China against the U.S., Japan, Vietnam, the Philippines, and India. Some elements of economic policy will therefore have been in line with PD, but there are other elements that undermine this grand strategy. Any 
sort of power political economic policy, like that of artificial currency undervaluation as China practices it, would therefore undermine its proclaimed grand strategy, even while serving the national interest in some way. The same trend is evident in the other two policy inputs of diplomacy and military strategy.

\section{Defining PD as China's Grand Strategy ${ }^{48}$}

Origins of the PD Rhetoric

China's PD grand strategy was developed over decades starting with Deng Xiaoping's foreign policy doctrine, which in turn was influenced by what Zhou Enlai had described as "peaceful coexistence" in the non-alignment movement at the Bandung conference in the mid-1950s. Deng then shaped the following foreign policy doctrine during his tenure as the People's Republic of China's (PRC) leading political figure:

[冷静观察] Lengjing guancha (making cool observations)

[稳住阵脚] shuozhu zhendi (securing its position)

[沉着应付] chenzhuo yingfu (calmly coping with issues)

[蹈光养晦] taoguang yanghui (concealing its capacities and biding its time)

\footnotetext{
${ }^{48}$ This is part of a paper presented at the $56^{\text {th }}$ Annual Meeting of the International Studies Association in New Orleans, February 18-21, 2015.
} 
[善于守拙] shanyu shuozhuo (good at maintaining a low profile); and [决不当头] juebu dangtou (never claiming leadership).

(Shen 2012, 7; quoted from Gong 1998)

From this doctrine it becomes clear that China has so-called antihegemonism as one of its main themes of foreign policy. At least until China became strong (which it was not yet during Deng's tenure) its capabilities and strengths were to be hidden. Conversely, this means Deng intended for its weaknesses not to be hidden; this is something we still find prominent today, as China keeps insisting that it is still in fact a developing nation and not yet a developed country (DC) yet. Internationally, Deng saw China as keeping a low profile so as to not distract from domestic economic development. The centrality of the security and survival of China as a nation-state is shown by the second sentence in this doctrine. Lastly, Deng saw China as being a rational actor, as exemplified by the first and third sentence in the doctrine.

Deng's foreign policy doctrine then was taken as a basis for PD, which was at first called Peaceful Rise but was changed because it was perceived as threatening by some nations and media outlets. Jiang Zemin continued in this tradition. Zheng Bijian further developed this doctrine and coined the policy of “Peaceful Rise” (和平崛起 heping jueqi) and popularized it in the West in a Foreign Affairs article in 2005. This was mainly a move by then-policy advisor to President Hu Jintao to counter the growing fears over China emerging as a great power, especially on the part of the adjacent nation-states in 
what China calls the first and second ring. Generally, China's unmanaged rise has caused conflict, just like the unmanaged fall. ${ }^{49}$ As Roy explains, "China is probably more sensitive to this phenomenon than any other rising power in history" (Roy 2013, 153). The comparison of China with Germany as a rising power is one of the most frequently used. ${ }^{50}$ The word rise seems to have been an issue with some of China's neighbors, as it was indeed perceived as slightly threatening. ${ }^{51}$ Therefore, the name of the grand strategy was changed to PD (和平发展 heping fazhan). ${ }^{52}$

It is clear that while Deng's foreign policy doctrine served as the main basis for the current PD in the beginning, not all of its four-letter combinations can still be said to be followed completely. For example, keeping a low profile and hiding one's strengths cannot be said to be strictly followed anymore, in a time where China throws around its weight in claiming territory in the ECS and SCS, builds up a blue water navy, or hosts the

\footnotetext{
${ }^{49}$ World War One, for example, may be said to have been partly caused by the rising German power and the falling Austro-Hungarian Empire. The rising Japanese Empire may be said to have caused conflict during the First and Second Sino-Japanese Wars, and Germany again during World War Two in Europe. For a good account of this phenomenon, see, e.g., Kliman (2014).

${ }^{50}$ Well-meaning analysts usually call China a "Neo-Bismarckian giant"; i.e., a great power that engages its neighborhood, reassuring it of peaceful intentions. A few analysts see China going in the direction of Germany under Wilhelm II, though.

${ }^{51}$ See, e.g., Roy (2013).

${ }^{52}$ For a good summary of the course of the course of "Peaceful Rise" rhetoric of the last few years, see Luttwak (2012), 273-276.
} 
Olympics. There is also evidence that China does attempt to exert its power; for example, concerning leadership of the Global South. ${ }^{53}$

\section{Defining $P D$}

After having first published a white paper on "China's Peaceful Development Road” (中国和平发展道路 zhongguo heping fazhan daolu) in 2005, a follow-up policy report was issued in 2011 entitled "China's Peaceful Development."54 The key foreign policies of the latter were:

Promoting the building of a harmonious world, (...)

Pursuing an independent foreign policy of peace, $(\ldots)$

Promoting new thinking on security, featuring mutual trust, mutual benefit, equality and coordination, (...)

Actively living up to international responsibility, (...)

Promoting regional cooperation and good-neighborly relations.

(China 2011)

\footnotetext{
${ }^{53}$ See, e.g., Pu (2012). For background on this debate, see Kawashima (2011).

${ }^{54}$ See China (2005), and China (2011).
} 
The main aims of these policies were found to be "promot[ing] development and harmony domestically and pursu[ing] cooperation and peace internationally," (China 2011) and to be specifically achieved through the following:

Accelerating the shifting of the model of growth, (...)

Further exploiting China's domestic resources and its market strengths, (...) Accelerating the building of a harmonious society, (...)

Implementing the opening-up strategy of mutual benefit, (...)

Creating a peaceful international environment and favorable external conditions.

(China 2011)

In a recent article, Barry Buzan identifies some key components of China's PD grand strategy:

Maintaining the exclusive rule of the communist party;

Maintaining high economic growth;

Maintaining the stability of Chinese society;

Defending the country's territorial integrity, including reunification and territorial disputes;

Increasing China's national power relative to the United States, other great powers and China's neighbours, and achieving a more multipolar, less USdominated, world order (anti-hegemonism); 
Maintaining favourable regional and global conditions for China's development;

Avoiding having others perceive China as threatening.

(Buzan 2014, 101)

Buzan's identified components of China's PD grand strategy are partly domestic. Usually, a grand strategy focuses on the international rather than the domestic level. However, many observers believe that it is especially true for China (but also in general) that the domestic and international levels are heavily intertwined. ${ }^{55}$ Christensen argued that China (as well as the U.S.) has used a particular grand strategy to mobilize domestic support and gain legitimacy. ${ }^{56}$ Ye Zicheng believes that China's grand strategy is constrained by the domestic problems it is facing. ${ }^{57}$ Layne argues that grand strategy, besides focusing on the structural level, necessarily needs to take the domestic level into account. $^{58}$

As much as PD may be both domestic and international, what needs to be added to Buzan's identifiers for this grand strategy is what is inherently included in it, perhaps without explicitly stating it (apart from catching up relative to the other powers):

\footnotetext{
${ }^{55}$ See, e.g., Christensen (1996), Layne (2009), or Ye (2011).

${ }^{56}$ See Christensen (1996).

${ }^{57}$ See Ye (2011).

${ }^{58}$ See Layne (2009).
} 
China's ambition to rise to great power status and to become a truly global power. After all, the chosen grand strategy of Peaceful Rise, which was later changed to PD, entails this. With rising nationalism and its increasing embrace by the CCP, regime legitimacy has increasingly been decoupled from pure economic growth domestically, but has also grown more intertwined with the rising reputation of China in the world. Projects like the building of a blue water navy, the creation of a "string of pearls," financing more and more infrastructure projects as part of foreign aid to developing countries, investment in supposedly more developed countries in North America and Europe, hosting the Olympics and World Expo, and claiming territory more assertively in China's surrounding seas all exemplify this trend. It is true, as Zheng put it, "China's development depends on world peace" (Zheng 2005, 24); however, the CCP's regime security increasingly does not depend on economic growth or development anymore, but rather on nationalism and legitimacy that is coupled with China's status, prestige, reputation, and the conversion of its perceived, increased relative power into realization of its goals-of its grand international strategy.

Some scholars argue that when it comes to China's grand strategy, one should differentiate not just between domestically and internationally relevant policies, but also between two identities that China developed as first, an ambitious great power and second, as a representative of the underdeveloped Global South. ${ }^{59}$ This dissertation is mainly concerned with international-level interactions and foreign affairs, and it

\footnotetext{
${ }^{59}$ See, e.g., Pu (2012), or Richardson (2012).
} 
understands grand strategy rather internationally in that this is what leads foreign and security policies and gives it reason. Of course, grand strategy may very well have domestic sources and policies catering to international projection. ${ }^{60}$ But the manifestation of a grand strategy should not be measured by looking inside a country, but rather by looking at how a particular country engages with other nations. Also, this dissertation subscribes to the perhaps conservative view that a country can only have one grand strategy. However, it does acknowledge that one grand strategy can manifest itself in different or even contradictory, ways and therefore perhaps can lead some observers to mistakenly think that there must be two grand strategies. In fact, even Zheng Bijian in China's "Peaceful Rise" to Great-Power Status talks of "three grand strategies—or "three transcendences" (Zheng 2005, 21):

The first strategy is to transcend the old model of industrialization and to advance a new one. (...) The Chinese government is trying to find new ways to reduce the percentage of the country's imported energy sources and to rely more on China's own. The objective is to build a 'society of thrift.' (...)

The second strategy is to transcend the traditional ways for great powers to emerge, as well as the Cold War mentality that defined international relations along ideological lines. China will not follow the path of Germany leading up to World War I or those of Germany and Japan leading up to World War II, when these countries violently plundered

${ }^{60}$ See, e.g., Shih and Huang (2015). 
resources and pursued hegemony. Neither will China follow the path of the great powers vying for global domination during the Cold War. Instead, China will transcend ideological differences to strive for peace, development, and cooperation with all countries of the world.

The third strategy is to transcend outdated modes of social control and to construct a harmonious socialist society.

In fact, only the second of what Zheng calls grand strategies or transcendences can be called a grand strategy, according to the traditional definition as utilized in this analysis. The first and third strategies are more domestically relevant policies, and may fall under those points that Buzan relates to China's regime security (maintaining CCP rule, high economic growth, social stability).

Judging by a triangulation of sources (and secondary literature) of the 2011 white paper on PD, Zheng's Foreign Affairs article, and Buzan's recent article in the Chinese Journal of International Politics, the following components of PD shall be discarded as lessor only indirectly relevant in an international context for the purpose of this dissertation's analysis:

- "Maintaining the exclusive rule of the communist party;

- Maintaining high economic growth" (Buzan 2014, 101) ("transcend the old model of industrialization” (Zheng 2005, 22)) 
- "Maintaining the stability of Chinese society" (Buzan 2014, 101) ("transcend outdated modes of social control" (Zheng 2005, 22))

Conversely, these internationally relevant components of PD shall be used to analyze whether China diverged from it:

- "Defending the country's territorial integrity, including reunification and territorial disputes;

- Increasing China's national power relative to the United States, other great powers and China's neighbours, and achieving a more multipolar, less US-dominated, world order (anti-hegemonism);

- Maintaining favourable regional and global conditions for China's development" (Buzan 2014, 101) (“China will transcend ideological differences to strive for peace, development, and cooperation with all countries of the world" (Zheng 2005, 22); “Actively living up to international responsibility" (China 2011))

- "Avoiding having others perceive China as threatening" (Buzan 2014, 101) ("transcend the traditional ways for great powers to emerge" (Zheng 2005, 22).

- Rising to great power status: increasing China's international reputation and prestige.

These components of China's grand strategy will facilitate the examination of singular cases of manifestations in the following section for convergence and divergence within the defined timeframe. 


\section{Theoretical Framework: Culturalizing Grand Strategy}

As existing attempts to explain the phenomenon of contradictions within China's grand strategy are unsatisfying, there is a real need for a new approach to analyzing it. As Beach and Pedersen write, "when the purpose of analysis is to craft a sufficient explanation of a particular outcome, we almost always need to combine mechanisms into an eclectic conglomerate mechanism to account for a particular outcome" (Beach and Pedersen 2013, 35). The two frameworks for analysis can be fused in such a way that it still makes sense to employ both at the same time, through a single synthesized framework. Lebow's framework at its core is comprised of the three cultural drives (or motives) of honor, interest, and fear. ${ }^{61}$ The concept of grand strategy with all its ingredients will build the basis for the synthesized framework. Its Western-centric origin is not of concern, since the cultural drives of honor, interest, and fear in the Chinese case in particular will add the necessary nuance and detail to neutralize the Eurocentrism of the theory of grand strategy in its classic form.

As mentioned above, the fact that grand strategy is an originally realist concept does not necessarily mean that cultural components cannot be considered along with it; this kind of analysis actually has been done in the past quite successfully. ${ }^{62}$ This

\footnotetext{
${ }^{61}$ As explained above, the drives of habit and reason will be omitted from this analysis, as habit is not emphasized very much anyway by Lebow, and reason is a Eurocentric cultural drive that does not really apply to China's case.

${ }^{62}$ See for example Booth (1979), or Johnston (1998).
} 
has been especially important when realism and other materialist explanations have failed to predict and explain phenomena that may be better explained by an approach taking intangible dimensions into account, as Colin S. Gray notes in his review of Ken Booth's Strategy and Ethnocentrism:

[C]apabilities often are not reliably self-explanatory. Even if we believe that we know what an identified adversary is doing or has acquired, can we be certain that we understand his motives? Moreover, given the less than completely rational and orderly world of policy- and strategy-making, it is distinctly possible that a foreign power has seriously mixed motives, and is functioning in a quite muddled fashion, opportunistically rather than with laser-like malevolent intentions.

In the same article, Gray also emphasizes that historical memory may play a very important role in the making of grand strategy:

[E]thnocentrism is as much a condition as a problem. In theory, the condition can be treated through education, if that is on offer in the classroom or in the field, survivably we trust, but this strategist believes that as a practicable matter it cannot be much ameliorated. We are what we are, and in the main we have strategic cultural DNA inherited from our tribe's unique strategic historical experience, somewhat common though the 
experience will be with that of a few other societies. Of course, culture does not work monocausally upon group behavior, but it is always likely to feature as a potent conditioning source of attitudes for the guidance of current behavior.

(Gray 2013, 1292)

In the same vein, Ken Booth elaborates more upon the relationship between strategy and culture, saying that

one's cultural heredity can prevent an individual or group from seeing (or seeing as acceptable) certain options which might nevertheless be rational in an objective sense. The kamikaze pilot is a good example. (...) Secondly, culture is important because it shapes the ends which create the problem to which rational thinking has to be addressed. If an outsider cannot understand or sympathise with the reasonableness of particular ends, he may not appreciate the rationality of the means.

(Booth 1979, 64)

Similarly, Booth agrees with the argument here that legitimacy plays a preeminent role and is defined in conjunction with culture. Legitimacy is a concept "which is both subjective and contextual" (Booth 1979, 68). 
Fear and the attendant search for security (and survival) will be mainly associated with the grand strategy design component of military strategy. Honor and the attendant search for prestige, status, and recognition will be mainly associated with the grand strategy design components of diplomacy and legitimacy. Also, (economic) interest and the attendant search for wealth is inherently connected to the grand strategy design component of economic policy. That is not to say that the same cultural drive cannot interfere with non-associated policy inputs of grand strategy design. To find out to what extent this happens or not will also be part of the analysis of this case, as well as how this could contribute to the internal incoherence of China's grand strategy design.

As explained above, honor and its manifestations occupy an important place in China's international politics, which can in many ways be said to exceed the importance attributed to fear or economic interest. The latter two cultural drives and their respective outcomes of security and wealth should rather be seen as a result of having attained prestige, status, and recognition. They will, however, help to reinforce honor and the attainment of prestige in the end.

Preliminarily, the problem with the Chinese grand strategy case seems to be that the Chinese government has attached its legitimacy to economic growth and success without any moral component, which is something Yan Xuetong has recently criticized, calling for a "humane authority" in China (Yan 2011). Similar to wealth, China is gaining in military power, modernizing its military, acquiring aircraft carriers, building a blue water navy, and aiming to achieve parity with the U.S. and Russia concerning nuclear weapons. 
This inspires fear rather than reverence in the surrounding nations, and even in the global community. Again, the above translation of prestige into Chinese as literally meaning aweor fear-inspiring shows the absolute importance of honor, prestige, status, and recognition.

Very similar to the noble family that acquired 'te' by financing the poor and needy in Van Ess's example for gaining prestige, China can be accused of the same strategy in terms of its acting as a spearhead of the developing world (the Third World) through foreign aid against the current global hegemon, the United States. This leads to internal as well as external legitimacy or recognition through the developing nations, elevating the external status and recognition for China, as well as legitimizing the ruling party's governing mandate at home, as manifested by rising nationalism. As far as China's relations and grand strategy regarding the great powers (United States, European Union [EU], Russia, Japan, India), it might be the case that China does not see a way other than arousing fear in its equals, the other and still higher-ranking great powers, and therefore enhancing its prestige through being feared by them.

Following the above analysis of the driving cultural forces in China's experience, honor and its search for prestige, status, and recognition should be considered the most important cultural motivation behind China's international relations. This is historically connected to China's internal and external legitimacy, which only goes to reinforce its importance. Material factors such as military and economic capabilities, as one would respectively associate with the motives of fear and interest, are to be considered less important. 
The following analysis of the six most salient case studies of China's behavior on the regional and international stage since 2009 will be evaluated with respect to motives and catering toward the national interest and proclaimed grand strategy. Close attention will be paid to analyzing the validity of the hypotheses that it is the driver of honor and to increase prestige, status, and recognition, which eventually leads to the internal incoherence of Chinese grand strategy design, as suspected.

\section{Core Argument: Honor in International Relations Equals Legitimacy for China}

As demonstrated above, the tributary system and China's distinctive history as the relatively unchallenged hegemon in East Asia set the tone for China's international relations. Undoubtedly economic interest and the search for wealth, as well as military considerations and fear, play a role in China's foreign affairs. There is a plethora of arguments regarding the tributary system and its purpose. As shown above, for some it was an economic exchange; for others it was a political alliance against the Mongols or other ethnic groups not organized in the form of a centralized state. But there surely can be no doubt that the tributary system served its symbolic purpose (whether or not that was its foremost purpose) of ordering China's surrounding neighbors hierarchically and giving status to those with which China conducted international relations.

But, as shown above, this also leads back to honor and the search for prestige. On the one hand, in Chinese ancient culture it was regarded as honorable to show 
that one was able to acquire wealth. On the other hand, it is certain that the military deterrent of China mattered, since the Chinese empire was an unmatchable adversary compared to many of its adjacent neighbors in terms of size of territory, population, advancement of civilization, or economic output. Having a centralized state apparatus and hereditary monarchy, along with the mostly Confucian (and some Legalist) state ideology, honor and prestige mattered greatly as a way to legitimize rule. Additionally, economic interest with wealth and fear with security certainly were two very important pillars contributing to this attainment of honor and prestige. In a system where there was no other legitimation, especially for the initial setup of a particular dynasty, this was crucial.

The theoretical argument aims to establish not only that honor played a big role in China's diplomatic history in the past, but also now in its current affairs. There are clear signs of this in recent decades, such as the publication of an important policy advisor, Zheng Bijian, indicating that China sought great power status in 2005; China's soft power initiative spearheaded by the creation of Confucius Institutes; how China presented itself during the Olympic opening ceremony in Beijing in August 2008; the rising assertiveness on China's part as a suggested consequence of changing perceptions of its rising versus a declining American superpower in the light of the global financial crisis which started in the developed countries, most prominently the U.S.; China's introduction of an aircraft carrier fleet to build up a blue water navy; China's space program to send a man to the moon; its ever-rising military budget and military modernization as a whole; and, most recently, the Chinese proposal and eventual foundation of the Asian Infrastructure Investment Bank. At first glance, it may not be too far-fetched to posit that some of these 
endeavors of the Chinese government were not undertaken solely to increase its GDP on the wealth side, or increase its security on the fear side. All of these examples have in common that they are aimed to increase China's prestige, reputation, recognition, and status.

However, in China's foreign affairs, honor's relation to legitimacy needs to be divided into internal and external legitimacy. One could easily fall prey to the misperception that foreign affairs are only related to external legitimacy; i.e., China's reputation, recognition, and status as perceived by the international community. However, China currently is still a centralized state with an authoritarian state form, no longer monarchic-hereditary, but still authoritarian, with a 'Frankensteinian' ideology which attempts to balance China's ancient history, culture, and imperial state ideology with the amalgam of Marxist, Maoist, and Deng Xiaoping thought, the latter of which is said to have largely withered away with China's embrace of state-directed capitalism. There are at least two developments one can identify in China's internal legitimacy: first, as an authoritarian state without the backing of a clear-cut, defined state ideology, China legitimized itself via its economic growth for much of the last few decades. The Chinese government has been quick to realize that this trend of economic growth in the double-digit or high single-digit range cannot carry on indefinitely. It still strives for economic growth, which as established through Chinese culture is related to the creation of prestige, but it has set out to diversify it. On the other hand, China has generally not reinforced nationalistic tendencies in its population, and has shied away from exacerbating these tendencies. In the last few years, they have loosened the reins on controlling nationalism; 
the state has actually appealed more to it and has tried to make the best use of such tendencies in the Chinese population. Also, there have been more and more references to China's ancient culture (Legalist, Daoist, and Confucian classics) and less than before to Communist ideology.

Second, the Chinese government, in the absence of legitimation by its own population, has increased its accommodation of some of its popular nationalistic demands, most prominently its historic enmity with Japan, which translates into its foreign affairs. Some of China's foreign affairs will therefore not speak to external legitimacy and China's search to increase its reputation internationally, but actually to internal legitimacy and the Communist government's search to stay in power via legitimizing itself to increase its domestic approval. The recent two-year ice age between China and Japan from 2012 to 2014, ending with the reluctant yet icy handshake between Xi and Abe in early November 2014, is an example of this. Another example may be the declaration of an air defense identification zone over the ECS, including the Senkaku/Diaoyu Islands. China's export restrictions on REEs, which mainly struck Japan in 2010, as well as China's support of Russia in the Ukraine-Russia-Crisis since 2014, are two more examples in which the Chinese government cared more about internal than external legitimacy. The latter three shall be examined in the case study groups below.

To reiterate, in terms of external legitimacy, China can be said to have an 'implanted gene' of acting as the regional hegemon in Asia. This comes from its longranging history as the central authority in its tributary system in hierarchically organizing 
the surrounding nations and states, with China at its pinnacle. However, China also has an acquired, deep-seated trauma, condition, aversion, or complex that many refer to as the 'One Hundred Years of Humiliation.' As such, China saw itself humiliated by the Western great powers and Japan. The latter have acted toward China without respect to its centurieslong status, partly colonized it, conquered it, and imposed the abandonment of its isolationist international policy over the course of the nineteenth century. Now, China is trying to climb back up to where it believes it rightfully belongs to overcome this acquired trauma. As mentioned above, there have been several obvious actions China has taken in the past decade or so which are clearly attempts to increase its reputation, like the Confucius Institutes, the Olympics, and the aircraft carrier fleet/blue water navy build-up. In the following case studies, I will analyze in reference to external legitimacy the following examples in the last couple of years in the post-2008 era: first, China's OBOR major diplomatic initiative to engage with neighboring regions in Central, South and Southeast Asia, Eurasia, the Middle East, East Africa, and Europe; second, China's proposal for the foundation of the AIIB since 2013; and third, China's continued participation in UN PKMs during the analyzed time period. All of these speak to China's focus on international reputation enhancement and, therefore, external legitimacy, at least at first glance.

Therefore, it is possible to argue that China is a perfectly rational actor in the international system by any (Western or Eastern) standards of measurement; i.e., mostly acting with economic interest (wealth) and fear (security) in mind. However, in certain circumstances honor, whether for internal or external legitimacy, makes China leave the 
course of ratio and enter an unreasonable climate. These aforementioned features of China's behavior toward foreign powers are critical in relation to honor as driving international relations of China vis-à-vis external legitimacy. In the end, this explains why China sometimes diverts from its grand strategy, and why most of the time it does not, as visualized below in figure 1 .

Objective: Explaining China's contradictory grand strategy manifestations
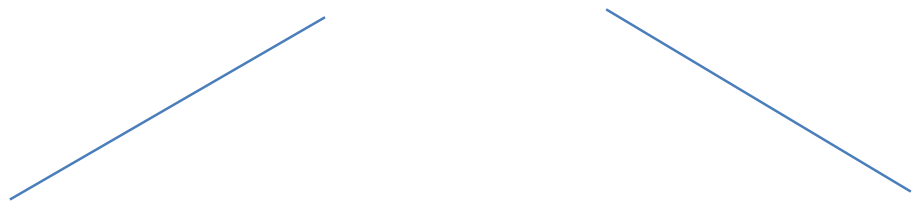

Peaceful

Assertive

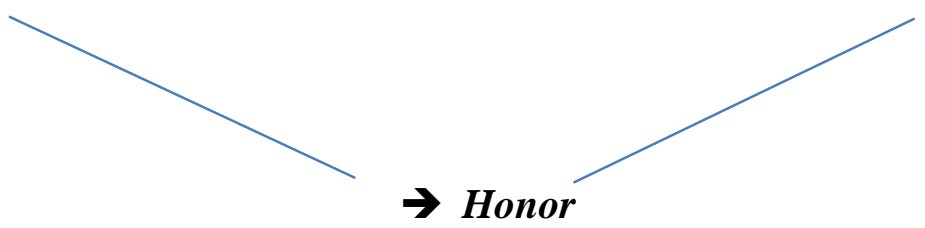

(Prestige, Reputation, Status, Recognition)

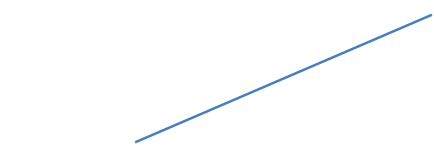

$\Rightarrow$ Legitimacy

External

Internal

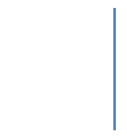

Peaceful

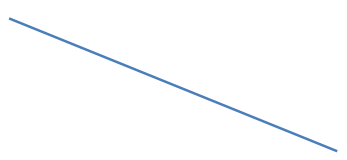

ful<smiles>CCC</smiles>

Mostly converging to

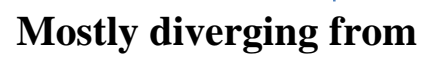

Peaceful Development

Figure 1: Core Argument. 
As argued above, the cultural driver of honor explains this grand strategy incoherence. Whether one calls this a variable or a constant is up for argument. Most scholars would argue that culture is a constant rather than a variable, since it does not change, almost never changes, or changes slowly. Assuming that it is honor that is of critical importance in explaining China's grand strategy design incoherence, then it is not too far-fetched to say that it can be considered an intermediate variable, since there are situations in which China predictably diverges from its grand strategy course and acts in a way that can be perceived as irrational by others. It can certainly be argued, too, that since the humiliation trauma has been ingrained in China's culture, it is part of the constant and, therefore, when China predictably diverges from its grand strategy, it is only natural that it would do so because it is ingrained in its culture. This means China will constantly diverge from its grand strategy in certain situations, not all the time. But since this sense of trauma underlies China's international policies, and is only triggered when honor and grand strategy do not fit certain conditions, it may be valid to still consider it a constant rather than a variable. 


\section{WITHIN-CASE STUDY GROUP ONE: DIPLOMACY}

Since Eric Teo suggested that China was trying to revive the tributary system in Asia, China has denied this observation and emphasized equality among Asian countries. According to Chinese officials, under the tributary system China guaranteed security of, and non-violence against, its smaller neighbours and received material goods in return, while under the current 'good neighbourly diplomacy' (睦邻外交, mu lin wai jiao) China gives material goods to neighbours in search for (sic!) a safe strategic environment.

(Jiang 2011, 66)

Nations in the 'Confucian zone' of civilization are supposed to accept China's natural leadership, not attempt to resurrect old empires or align with a foreign hegemon such as the United States.

(Pillsbury 2015, 205)

\section{Case Selection and Classification}

China's diplomacy during the six-year timeframe (2009-2015) has produced many incidences that could be used for analysis. The chosen case pertaining to 
diplomatic policy in China's grand strategy design and its internal legitimacy is one of the most salient and memorable in the timeframe. In this case, China has made an exception to the otherwise 'golden rule' of sovereignty in the case of Russia's annexation of the Crimean peninsula, as well as the support for secessionists in the Ukrainian East. It came as a surprise to many that China did not take Ukraine's side, since Russia violated Ukraine's territorial integrity by annexing Crimea and sending troops (disguised as vacationing soldiers traveling privately) to Eastern Ukraine. Also, the chosen case in relation to China's external legitimacy is the massive diplomatic initiative of engaging Eurasia called OBOR. Naturally, since this initiative is directed outward, it is mostly relevant to external legitimacy. However, it has a dimension of relevance to internal legitimacy, insofar as it can be understood as an economic stimulus for the Chinese economy and insofar as receiving external legitimacy benefits China internally (as noted in the preceding chapter on China's historic tributary relations with its neighbors).

Another salient internal legitimacy case in the timeframe is the 'ice age' in Sino-Japanese relations beginning with Japan's acquisition of the majority of the Senkaku/Diaoyu Islands in mid-/late 2012 and ending with the icy handshake between Xi and Abe in late 2014. This case is related to the eventually chosen case of the ADIZ proclamation over the ECS, which may be considered China's reaction to Japan's acquisition of most of the Senkakus from private owners.

Another important case for external legitimacy during the analyzed timeframe was China's decision to leave the path of only negotiating bilaterally over 
territorial issues concerning its borders. In this case, the territorial disputes in the SCS were triggered by China's generous claim extending to the shores of Brunei and Singapore, thousands of miles away from its Southern coast and southernmost island province of Hainan. ${ }^{63}$ In and of itself, this assertive claim relates only to internal legitimacy, but more generally, stepping away from the 'bilateral-negotiations-only' assertion is an issue of external legitimacy, since China cooperated according to and with the international community (even though there were no results at the time).

Also, the agreements regarding environmental protection between China and the U.S. in late 2014 were among the external legitimacy cases in diplomatic policy. China struck a deal with the U.S. in emission cuts in the run-up to the Lima and Paris environmental conferences. Moreover, China's offers to help with the refugee crisis in the Middle East was a possible case in this context.

The case of losing diplomatic control over the DPRK is another good example of a case that negatively affects external legitimacy. On the one hand, when a torpedo of the DPRK destroyed a South Korean submarine in 2010 (the so-called Cheonan sinking incident), the Republic of (South) Korea (ROK) pressured China to condemn the DPRK's behavior and renounce its backing of the DPRK as an ally. China did not give in to this demand, which cost it external legitimacy with the international community. On the other hand, while standing with the DPRK in 2010 still seemed coherent with past alliance

${ }^{63}$ See Luttwak (2012) for an in-depth account of this. 
behavior (albeit irresponsible for an ambitious great power), in recent years-and especially since the late 2011 death of Kim Jong Il and the assumption of leadership by Kim Jong Un in early 2012 - the DPRK has appeared to get further out of control. This is the case even for the Chinese, who essentially represent the DPRK's only trade partner. This situation is exemplified by the recent supposed hydrogen bomb test and expedition of nuclear ambitions in the DPRK and the Chinese reaction that followed, renouncing such behavior. Also, the DPRK, which had properly applied to become a founding member of the AIIB foundation, was turned down by the Chinese, who ironically cited their underdeveloped state as a reason (despite the fact that this would make the DPRK the perfect member and beneficiary of infrastructural investment under the AIIB program). Thus, the Chinese leadership, which changed from Hu Jintao/Wen Jiabao to Xi Jinping/Li Keqiang just a few months after the DPRK leadership was assumed by Kim Jong Un, may have made the decision to rid itself, at least diplomatically, of the North Korean comrades to gain more external legitimacy.

Nevertheless, the most salient cases selected were the diplomatic reaction to the Ukraine crisis and the OBOR initiative. The reasons for the selection of these cases are that they clearly fall at the international level, involving less domestic politics than the other cases, as well as receiving the most media attention. 


\section{The Retreat from the Non-Interference in Internal Affairs Paradigm ${ }^{64}$}

\section{Introduction of the Case}

Russia has historically been both a competitor and a strategic ally to China. The resolution of territorial disputes with Russia is relatively recent, albeit the creation of an independent Mongolia and the retaining of Northeastern territories bordering Heilongjiang province are still a dart in China's eye. Even during ideological convergence in Cold War times, and to a certain extent also today, Russia and China's relations continue to be both cooperative and sometimes conflict-breeding.

China's strong emphasis on territorial integrity, sovereignty, and noninterference of one country in another's internal affairs has been a hallmark of its foreign policy approach as well as an important factor in its PD grand strategy. Upholding this norm, sometimes said to be the Golden Rule in the Law of Nations, means that China has to act accordingly and also be persistent in its international behavior and reactions to other countries' interference with each other's internal affairs and violation of each other's territorial integrity and sovereignty.

\footnotetext{
${ }^{64}$ An adapted version of this sub-chapter was accepted for publication as part of a research article in Culture Mandala, vol. 12, no. 1. Previous to that, parts of this sub-chapter were also presented as a working paper at the $56^{\text {th }}$ Annual Convention of the International Studies Association, New Orleans, Louisiana, February 1821, 2015.
} 
Against this background, it was a surprise to many observers that China reacted as it did in the Russo-Ukrainian conflict over Crimea, as well as the eastern Ukrainian provinces around the cities of Donetsk and Lugansk. China quietly took the side of Russia in this international maneuver, in which Crimea joined the Russian Federation as a new republic and the eastern Ukrainian provinces may or may not end up doing the same, short of full autonomy from Kiev. ${ }^{65}$ Thus, China's reaction to this event (i.e., not persisting in its stand that non-interference in others' internal affairs is paramount in international law) is a major divergence from its grand strategy. Some of the analysts that often suspect a 'China threat' for neighboring countries were already predicting a major shift in China's policy, to result in China emulating this Russian model of acquiring claimed territory. China was thus compelled to publicly announce that it would not do so. ${ }^{66}$

\section{Detailed Course of Events of the Case}

As explained earlier, China has a long tradition of taking the side of countries that have been the victims of sovereignty infringement, especially in regard to the non-interference in internal affairs and the territorial integrity of any country. Sean Kay writes on China's history concerning this kind of behavior:

\footnotetext{
${ }^{65}$ See, e.g., Tiezzi (2014a), or Tiezzi (2014b).

${ }^{66}$ See Zhang (2015).
} 
Chinese officials also view American intervention in other countries-for instance, during the Kosovo and Iraq wars - with concern that the United States is setting new precedents regarding sovereignty with possible implications for Taiwan, Tibet, and Xinjiang Province. Conversely, China was not impressed with Russia's illegal annexation of Crimea, which grossly violated Ukrainian sovereignty.

(Kay 2015, 125)

Thus, China taking Russia's side in the Ukraine crisis came as quite a shock to many observers of China's international behavior over the last several years, particularly in light of China's emphasis on territorial sovereignty in its own grand strategy. China's behavior makes a balance-of-power kind of impression, in which the West and East confront each other again as adversaries, just as they did during the Cold War. Moreover, a Sino-Russian deal to which both parties agreed during a May 2014 visit, in which China secured large quantities of oil and gas from Russia in addition to other areas of economic cooperation, could give the impression that China received a pay-off for taking Russia's side, ultimately taking advantage of economic sanctions imposed on Russia in the aftermath of its annexation of Crimea. This impression was prevalent at least the first couple of months after the crisis; a few months later, there came news of China investing heavily in Ukraine and "Kyiv [increasing] its agricultural trade with Beijing by more than 50 percent" (Sieren 2015). 
We hope relevant parties will exercise restraints and make efforts to ease the situation rather than further escalate it. The relevant conflicts must be resolved through diplomatic means on the basis of taking into account the interests of all parties. We advocate the establishment of the mechanism of international contacts to seek a political solution under the framework of law and order. (...)

Respecting the sovereignty and territorial integrity of each country is an important principle that the Chinese diplomatic policy has been constantly upholding, which will not change.

(China 2014)

As mentioned above, after the Crimean annexation by Russia, China was able to strike a gas supply deal with Russia in May 2014, likely meant to counter or at least alleviate the sanctions set on Russia by the West, in addition to economically benefitting China:

The effects of U.S. policy have been all too apparent as Russian-Chinese cooperation has accelerated rapidly since March 2014. With regard to overall political relations, during his state visit to Shanghai in May, Putin gushed that bilateral interactions had become the "best in all their many centuries of history.' Striking also was the Russian president's frequent use of the term 'alliance,' albeit not with reference to military ties. In addition to this positive rhetoric, it was during the May trip that Russia and China finally signed their mammoth 30 -year, $\$ 400$ billion gas deal. After more 
than ten years of inconclusive negotiations, it seems that Western sanctions helped break the impasse by pushing Russia to accept China's price terms.

(Brown 2015)

This move could be interpreted as China taking advantage of Russia's weakened economic position due to the economic sanctions against it. However, as presented in the media, the particular timing of the closing of the deal with Russia (during the height of international pressure and shaming campaigns on Russia) does give the impression of China taking Russia's side in this conflict.

In late February 2015, the Chinese ambassador to Belgium, Qu Xing, “call[ed] on the West to 'abandon its zero-sum mentality' [and] (...) said the West should take 'the real security concerns of Russia into consideration"” (Boren 2015). Furthermore, he found:

that the nature and root cause of [the] Ukraine crisis was the game between Russia and western powers, including the United States and the European Union. 'There were internal and external reasons for the Ukraine crisis. Originally, the issue stemmed from Ukraine's internal problems, but it now was not a simple internal matter. Without external intervention from different powers, the Ukrainian problem would not develop into the serious crisis as it be (sic!) [.]' (...) On the one hand, China and Ukraine are traditional friendly countries. China has always pursued the principles of 
non-interference, respect for sovereignty and territorial integrity of Ukraine. And on the other hand, China acknowledges that the issue involved complicated historical elements.

(Sun 2015)

The Chinese ambassador's allusion to the paradox between pursuing non-interference and territorial integrity and certain historical elements is particularly striking in this Xinhua article.

Until recently, the situation left two powerful actors, the EU and Russia, continuing to fight over the Ukraine's allegiance without any real success. Neither the EU nor Russia can now be said to have the whole of Ukraine under their sphere of influence. True to the proverb of 'When two people quarrel, a third rejoices,' China seems to have actually emerged as a winning actor from the Ukraine crisis. On the one hand, as mentioned, Russia came as a junior partner to a deal with the Chinese, with a planned cooperation concerning oil and gas access for the Chinese at favorable prices, among other points. On the other hand, it was not only the Russians who were forced to decrease their prices; "Ukrainians have had to offer favorable prices, [too,] sometimes giving discounts of up to 50 percent on purchases from agricultural companies" (Sieren 2015), of which China took advantage. 


\section{Localization of the Case in Terms of Honor and Legitimacy}

As presented above, the obsession with sovereignty, territorial integrity and non-interference in others' internal affairs stems from China's experience with the intrusion of the Western powers (plus Japan) in its territory—-the so-called 'Century of Humiliation.'

Part of the 'Century of Humiliation' is the fact that China does have a longterm goal of recovering territories that it considers to have previously been parts of China. These territories include India's Arunachal Pradesh (what China calls 'South Tibet') the now-Russian parts of the Manchurian Northeast, today's Republic of Mongolia (what China calls 'Outer Mongolia'), the Japanese-controlled Senkaku Islands (or 'Diaoyu' Islands in Chinese), and - perhaps the most comprehensible claim-Taiwan. Naturally, the 'Chinese-ness' of these territories and islands is a matter of debate Even Taiwanseemingly the clearest case of cultural and historical closeness to China — has had a history of separation from the mainland and colonization by other powers, such as the Netherlands and Japan. To argue that Arunachal Pradesh ('South Tibet') rightfully belongs to China because it was once under Tibetan influence is even more far-fetched, to say nothing of the question of whether the northern part of Tibet should be an inherent part of China in the first place.

That China should suddenly show overt support to a big power (Russia) against a relatively weak one (Ukraine) in annexing a peninsula (Crimea) with strong 
historical and cultural influence from the nearby annexing aggressor does give a sense of China readying itself to become such an aggressor itself, with Taiwan first in line for annexation. China's 'problem' regarding these lost territories is the fact that the 'Century of Humiliation' left China weak and left its former territories in the hands of major powers (Russia, India, Japan) or at least with guarantees of protection from major powers (Russia, U.S.).

How, then, can we explain China's long-lasting preoccupation with noninterference in other countries' internal affairs? China was—and still is—a country that is clearly more on the pluralism side (putting a premium on state sovereignty) than the solidarism side (putting a premium on transnational convergence such as human rights) of an international society spectrum. As such a pluralist state, it is natural for China to emphasize and jealously protect its sovereignty, particularly in light of its own experience of relinquishing some of that sovereignty to infringing great powers (e.g., granting Hong Kong as a British colony).

Furthermore, China has historically been more used to being the aggressor (i.e., infringing on others' sovereignty, such as by claiming suzerainty over adjacent states via its tributary system). Given its paradoxical development during the mid-nineteenth to mid-twentieth century, it was left with little choice but to defend its own borders in the weak position it held following the Japanese occupation of World War II and the ensuing civil war between the GMD and CCP followers. Hong Kong and Macao would be marks of the 'Century of Humiliation' for much of the Cold War, and Taiwan remains so today. 
With rising ambitions (i.e., the rise to great power status via PD), China is behaving more and more assertively. Moreover, the (apparent) paradigm change in the course of the 2008 Global Financial Crisis may also be reflected in China's stance on non-interference, as seen in the Ukraine case.

Compared to the Russo-Ukrainian case-in which the annexed Crimean peninsula has a two-thirds majority of Russians, allowing Russia to reference the right to self-determination of peoples - there are not such high amounts of Han-Chinese ethnic minorities (or majorities) in other states adjacent to China's territory. The historical aspect (i.e., the fact that Crimea has changed hands a couple of times and that, even though it was part of Ukraine in recent decades, Russia has a historical claim to Crimea as well) may have been more important than the ethnic aspect in determining China's initial reaction to the case. Regarding its own former territories, China argues mostly in terms of history and former ownership in its Qing dynastic times, when China reached its biggest territorial extents, and the CCP sees itself (more or less naturally) as the legal successor of this empire. The SCS is a good example of this, since the archipelagos affected are uninhabited, and therefore there cannot be a claim based on the self-determination of peoples. ${ }^{67}$ Speculatively, China's behavior in the Crimean case, which is not in line with its previous stands on non-interference, can thus give the impression that China is getting ready to

\footnotetext{
${ }^{67}$ Tibet is the only clear case of Han-Chinese population which China claims as its inherent territory. An exception to this is the 'detour' claim of arguing that 'South Tibet' should be part of the Tibetan Autonomous Region of China, or possibly that 'Outer Mongolia' should be part of the Chinese 'Inner Mongolia' province.
} 
adjust its standpoint more to its growing power status and territorial ambitions in its neighborhood.

Naturally, the first step in regaining honor and legitimacy would be to lay the groundwork to regain the territory that was 'lost' to neighbors at the end of imperial times, which China sees as a humiliation to this day. For its domestic population, internal political legitimacy would be enhanced if China could regain these lost territories. The second step is related to China's relations with Russia. China suffered semi-colonial encroachment from Russia in its Northeast area during the late nineteenth and early twentieth century, as well as Russia's later support for an independent Outer Mongolian buffer state. Relatedly, China was always considered the 'junior partner' in the alliance between Mao and Stalin from in the early 1950s until the Sino-Soviet split. With the energy deal that China and Russia closed in the course of the Crimean annexation and continuing secessionist conflict in eastern Ukraine, China has suddenly become the 'senior partner' next to Russia. This symbolic switch of positions is another alleviation to the 'Century of Humiliation' trauma, thanks to Russia's admission of China's status and prowess (albeit from a position weakened by the Western sanctions). 


\title{
Determining Convergence with or Divergence from PD Grand Strategy
}

\author{
Defense of territorial integrity
}

Even though the annexation of Crimea by the Russian Federation and the on-going secessionist efforts in Eastern Ukraine are not directly related to China's own territory, China had never previously allowed any power to interfere with any other state's internal affairs—including its own — and thus to violate the 'golden rule' of territorial integrity and sovereignty. In this context, not objecting to Russia's intervention in Ukraine may be considered counterproductive to China's own standpoint on sovereignty and territory. In international law, it is very important to act consistently. By not taking a clear stand against the violation of territorial integrity, China arguably makes itself vulnerable to such actions, as the Russian claim was based on the Russian ethnicity of the Crimean population. This would expose Chinese Xinjiang, Tibet, and Inner Mongolia. Therefore, China diverged from its PD grand strategy regarding the factor relating to the defense of territorial integrity (see table 2 for an overview of divergences and convergences in this case).

Increase of national power

In the conflict between Russia and the Ukraine, taking either side may not directly be considered an increase or decrease in China's national power. However, even though this issue does not have a direct effect on China's national power, one could argue, 
in light of the energy deal with Russian, that China's taking advantage of the conflict did increase its national power. That is, China leveraged the situation, first, to come to terms with Russia on below-market-price access to natural resources in the neighboring state, and second, to diversify its energy resources acquisition through this deal. Brown writes:

At present, around 80 percent of China's energy is imported from the Middle East and West Africa. This represents a major strategic vulnerability since, in the event of conflict, the United States would use its naval superiority to control the Malacca Straits and cut off the supply of these vital resources. Closer ties with Moscow help reduce this problem since Russia, along with Central Asian states, can provide oil and gas supplies via more easily protected overland pipelines[.]

(Brown 2015)

Moreover, the deal switched the roles of the two countries compared to post-World War II, when China was inferior to the Soviet Union, to a situation in which China is far superior, at least economically, to Russia.

Anti-hegemonism

Anti-hegemonism, or balance-of-power theory, would prescribe that one should side with the weaker side in a conflict. By siding with Russia versus the unified West (i.e., the European Union and the U.S.), China did follow this principle. However, 
China's action as interpreted as going against the U.S. would already meet the conditions of converging with anti-hegemonism, but it is more than clear that China converged here. Also, in this case, since Ukraine is thousands of miles away from China's borders and can be said to be even on a different continent entirely, it would be hard to accuse China of having hegemonic ambitions in that sphere. ${ }^{68}$

Maintenance of favorable economic markets

In the case of keeping the international markets favorable, this action was both convergent and divergent to the goal of maintaining a favorable economy at the same time. China converged insofar as it struck an energy deal with Russia in the background of the crisis, among other stipulations of closer cooperation. This brought China better prices and a diversified supply route, as mentioned above. In addition, China gained greater access in Ukraine - arguably at the expense of Russia - concerning foreign direct investment (FDI) and acquisition of agricultural products (e.g., wheat). However, China diverged insofar as its actions may have aroused an impression of East-West confrontation, which may translate to economic relations (as it has for Russia already). Certainly, China is seen to be expecting this reaction by hedging its energy supply through the deal with Russia, despite the fact that its own diplomats paradoxically called for less thinking by the West along the lines of Cold War mentality.

${ }^{68}$ In the event that China goes against the U.S. or U.S. allies in East Asia, Southeast Asia, or South Asia, conforming to anti-hegemonism may also carry an accusation of China's own implicit regional hegemonic ambitions of China. 


\section{International responsibility}

At first glance, it is difficult to dispute that China was encouraging conflict by subtly backing Russia in this case. This may certainly be considered irresponsible by any standard of measurement. Perhaps a consistently neutral position would have served China best in this matter, and perhaps it was trying to make up for this misstep afterwards by sweeping into Ukraine, funneling in FDI, and importing agricultural products from there. Nevertheless, at second glance, as Brown writes,

[A]lthough undoubtedly carried out using aggressive means, Russia's intervention in Ukraine was actually defensively motivated. The February 2014 revolution in Kiev brought to power a radically pro-Western government that explicitly sought to reorient Ukraine away from Russia's sphere of influence. This was perceived by Moscow to be an unacceptable threat to national security, especially because it was believed it would eventually lead to Ukrainian NATO membership. Were this to have occurred, the Alliance would have gained the strategically important Crimean peninsula, as well as a 1,200-mile frontier with Russia's European heartland. To eliminate this danger, Russia permanently seized Crimea and is using the separatist movements in Donetsk and Lugansk to prevent Ukraine's successful integration with the West.

(Brown 2015) 
Be that as it may, a Chinese endorsement of such aggressive means cannot be said to be responsible behavior on the international stage, when the supposedly 'offensive' actions of the Ukrainian people (protesting the pro-Russian government and then peacefully voting for a pro-Western government) were non-violent in nature, whereas the Russian actions of forcibly annexing Crimea and overtly supporting Eastern Ukrainian secessionist efforts both involved the use of military power. Thus, even at second glance, China's reaction in this case is a clear divergence from its PD grand strategy.

Avoidance of 'China threat' misperception

Both aligning with Russia and selfishly taking advantage of the situation of the Russian ally contribute to China being perceived as a threat in this situation. Naturally, to align with authoritarian Russia rather than democratic Europe or the U.S. is in itself a factor in this perception of China as a threat. Beyond this, however, the unrelenting what Luttwak calls 'state autism' in the aftermath of striking the energy deal with Russia and exploiting investment vacuums in Ukraine also fail to make China appear as benign future, and potentially regional, hegemon. ${ }^{69}$ On top of this, endorsing such aggressive means as a unilateral annexation does not help to present a peacefully rising China, which itself has territorial ambitions in the surrounding seas and borderlands. Since China's response did not succeed in avoiding others' perception of China as a threat, China thus diverged here from the PD grand strategy.

\footnotetext{
${ }^{69}$ See Luttwak (2012).
} 
Increasing China's international reputation

Whereas internally the presentation of China as the senior partner next to junior partner Russia may have given China more prestige with its own population, it may actually have decreased China's international reputation. Along with the perceived future threat coming from China, this move was thus more or less counterproductive. Therefore, China diverged from the PD grand strategy on this count, as well.

\begin{tabular}{|c|}
\hline Factor in PD \\
\hline Defense of territorial integrity \\
\hline Increase of national power \\
\hline Anti-hegemonism \\
\hline Maintenance of favorable economic \\
markets \\
\hline International responsibility \\
\hline Avoidance of 'China threat' \\
misperception
\end{tabular}

\section{Convergence / Divergence}

\section{Divergence}

(not objecting to Russia's intervention into Ukraine contradicts China's own standpoint)

Convergence

(no direct effect on China, but energy deal with Russia, plus more FDI into Ukraine)

Convergence (siding with Russia versus the West)

Convergence \& Divergence (convergence: China and Russia's deal; divergence: antiquated East-West thinking may translate negatively to econ. relations)

\section{Divergence}

(China sided, at least at first, with the aggressor side of this conflict; neutral in UN)

$$
\text { Divergence }
$$

(threat perception by others increased because of alignment with the Russian aggressor)

Divergence

(no improvement in China's reputation, rather damage because of contradicting itself)

Table 2: Divergence from or convergence with PD in the case of the legal non-persistence on the norm of territorial integrity in the case of the Crimean annexation and Russia-backed encroachments in Eastern Ukraine. 


\section{Alternative Explanations}

It is possible to argue that China is engaging in raw-power politics without any attached values and opted to take Russia's side in this case despite its rather consistent stance on the issue of non-interference. We have seen China increasingly augment the international market on energy resources in the last few years, acting in a neo-mercantilist fashion. The Russia energy deal combined with the later heavy investments in Ukraine paint an equally 'beggar thy neighbor' picture, which can be described as selfish or, according to Luttwak, 'autistic. ${ }^{70}$ As such, the premium would be on 'interest' in this case. Nevertheless, this may be an all-too-Eurocentric way of arguing.

It is also possible to conceive this step in the political arena by China as having been brought on by the Sino-Russian agreement that was released only days after China taking Russia's side. A similar agreement between Mao and Stalin in the early 1950s placed China, having just overcome years of Japanese occupation and the ensuing Civil War, as junior partner to Russia (i.e., seeking Russia's help). This time, China took advantage of Russia's suffering under a Western embargo and, in general, its dependence on the export of natural resources. In effect, China has now become the senior partner. The premium in such an explanation would be placed on 'economic interest.' Even so, the satisfaction of looking down on Russia in this situation comes after centuries of competition because of border disputes and Russian interest in Manchuria. In this respect,

\footnotetext{
${ }^{70}$ See Luttwak (2012).
} 
from China's perspective, Russia is not really different than the Western powers or Japan, and 'honor' may play a role even in this explanation.

Finally, it is possible to speculate that China may be preparing itself to annex territories that it historically considers to be part of China. We have seen such attempts in the ECS and SCS, and it could be possible for them to happen on land as well. For the most part, these territories are in today's North India, the Russian Far East, and the Mongolian Republic, although Taiwan would be the first step before anything else could be considered for annexation. The Russian argument for including Crimea into its federation was related not only to the ethnicity of the local population but also to historical claim. The Russian Far East and Taiwan would best fit such an argument, if China considered doing the same. For North India and Mongolia, China could only claim to act on behalf of two of its many minorities, the Tibetans and Mongolians, in addition to historical claims and the "belonging-together" of North Tibet and South Tibet and of Inner and Outer Mongolia. If we subscribe to this speculation, we can reason that this nowinconsistent behavior may or may not become more consistent and be followed by greater Chinese assertiveness in the future.

\section{Conclusion of Case Analysis}

China's inconsistent behavior in the Ukraine crisis mostly pertained to internal legitimacy. The biggest surprise to the international community was that China, 
for the first time, did not stick to its 'golden rule' of non-interference in internal affairs, i.e., putting sovereignty and territorial integrity on a pedestal. Standing up to the 'West,' and the U.S. in particular, is certainly according to the will of many hyper-nationalists within China, whether it is for the right reasons or not. Internally, securing an energy supply from Russia can certainly be said to be rational behavior on the part of China, even if it is inconsistent with foreign and security policy.

With the subtle backing of Russia in Ukraine, China diverged from its PD grand strategy. Only the very marginal gains that it could get from more trade with Ukraine in the aftermath and the favorable conditions with Russia could partially rectify China's behavior to be still in line with PD grand strategy. More energy resources add to Chinese power, and the diversification in supply make it less vulnerable to possible sanctions by the West in the event of more Chinese aggression in the ECS and SCS - especially if Japanclaimed maritime territory is annexed, which would entangle the U.S. in a conflict.

Besides the cultural driver of interest - which may have driven China to be opportunistic and evaluate the energy deal with Russia as more important than the noninterference principle, and which would arguably be more related to fear-honor played a critical role here as well, as China now finally appeared as the senior partner in dealings with Russia. First, Russia and, later, the Soviet Union (as part of the Western great powers conglomerate) had territorial ambitions in the Chinese Northeast, as still evidenced today by Russian buildings in Manchuria's capital of Harbin. Czarist Russia annexed some of 
these more remote territories when the last Chinese (Manchu-led) dynasty of the Qing was weak during the late nineteenth century, trying to gain access to southern ports from there. ${ }^{71}$

Second, when China became communist in the aftermath of the Civil War and struck a deal with the Soviet Union in 1950 for an alliance and friendship that was to last thirty years, China was clearly the junior partner with the big bear as the senior partner. China naturally was still in shambles from ridding itself of the Japanese occupiers and the ensuing protracted civil war of Communists versus Republicans, whereas the Soviet Union had had time since the end of World War II in 1945 to consolidate internally and regroup. This alliance between Stalin and Mao would not last long, and China began to abandon its Soviet comrade in the early 1970s for the U.S., mostly since the U.S. seemed to be the weaker of the two; therefore China switched sides, acting according to anti-hegemonism. So, to now appear as the senior partner coming 'to the rescue' of the Russian Federation, which was in turn weakened by Western sanctions, would seem to carry much satisfaction for China in light of the historic Russian superiority. Therefore, rising in status against Russia and 'locking in' that status with an energy deal serves as a 'correction' to what historically had gone wrong during the 'Hundred Years of Humiliation' era, as well as during the Cold War to some extent.

\footnotetext{
${ }^{71}$ Russia - connected to its long-standing obsession with gaining access to ice-free ports-Port Arthur (today's Lüshunkou district of Dalian city) was annexed during that time in history, and a railway from the Russian homeland all the way to Port Arthur was built to gain access to this ice-free sea haven. Incidentally, the recent annexation of Crimea is equally connected to the Russian search for ice-free sea ports much like this late nineteenth-/early twentieth-century case.
} 
Third and finally, as mentioned above, the internal status and prestige gained from standing up to the 'West,' and the U.S. in particular, is also closely connected to honor and the search for prestige, status, reputation, and recognition.

\section{The One Belt, One Road Major Diplomatic Initiative ${ }^{72}$}

\section{Introduction of the Case}

Since late 2013, President Xi Jinping has been promoting the idea of the OBOR initiative, sometimes referred to as the OBOR strategy. ${ }^{73}$ This major diplomatic initiative became a concerted effort of the Chinese National Development and Reform Commission, the Ministry of Foreign Affairs, and the Ministry of Commerce. The full name of this diplomatic initiative, which is typically referred to as OBOR, is 'Silk Road Economic Belt and Twenty-First-Century Maritime Silk Road.' Geographically, the historical Silk Roads—-land-based and maritime — are kept as they were during imperial times with some additional corridors; examples include China (Tibet)-Pakistan-Indian Ocean, or China-Myanmar-Bangladesh-Indian Ocean. ${ }^{74}$ "The Belt and Road routes run

\footnotetext{
${ }^{72}$ An adapted version of this sub-chapter was published as part of a research article in Tamkang Journal of International Affairs, vol. 20, no. 1 (July 2016), pp. 1-60.

${ }^{73}$ Unless otherwise stated, this chapter will refer to OBOR as a diplomatic initiative, since the term strategy in the context of diplomacy might be confused with the security concepts of grand strategy, tactics, and so forth.

${ }^{74}$ Here, too, one cannot help but think of the Chinese equivalent of the Russian obsession with ice-free seaports; that is, the possibility of facing a hypothetical traumatic experience in the form of a U.S.-initiated
} 
through the continents of Asia, Europe and Africa, connecting the vibrant East Asia economic circle at one end and developed European economic circle at the other. The (...) Belt focuses on bringing together China, Central Asia, Russia and Europe” (Xinhua 2015b). On the other hand, the maritime route "is designed to go from China's coast to Europe through the South China Sea and the Indian Ocean in one route, and from China's coast through the South China Sea to the South Pacific in the other" (Xinhua 2015b). ${ }^{75}$

Worth mentioning are some reservations from the scholarly and policy community about the OBOR initiative; while it is designed with a decades-long trajectory, it is still quite recent, having begun in late 2013 and been put into government documents in early 2015. As the renowned Chinese scholar Chen Dingding correctly assesses,

the OBOR initiatives (sic) are not guaranteed to succeed and in many ways they might actually fail if the Chinese government does not play its cards right. And there is some evidence that the government might not be handling its cards right at the moment.

(Chen 2015)

\footnotetext{
naval blockade on the Malacca Strait, which is central to the maritime Silk Road and China's access to trading with much of the world via ships. It seems that a hedging behavior underlies many such diplomatic initiatives and infrastructural projects, which seem altruistic at first but paranoid at second glance. Also consider China's interest in the Arctic and possible future sea routes via an ice-free global North.

${ }^{75}$ See Appendix, illustration 1.
} 
It should be noted that, although the most common designation is OBOR initiative, Chen is not entirely wrong in using the plural initiatives. As Reeves points out, besides the OBOR being one diplomatic initiative, "the concept also calls for the establishment of a[n FTA] between China and (...) ASEAN[.] As such, the strategic concept is a concerted effort to expand China's economic relations within a 'one bank, two belts, three corridors, one FTA' framework" (Reeves 2015, 22).

\section{Detailed Course of Events of the Case}

The first part of the concept for the OBOR — the land-based, traditional Silk Road for the twenty-first century — was first mentioned by President Xi while traveling to neighboring Kazakhstan in September 2013. "In a speech delivered at Nazarbayev University, Xi suggested that China and Central Asia cooperate to build a Silk Road Economic Belt. It was the first time the Chinese leadership mentioned the strategic vision" (Xinhua 2015b). This, of course, makes sense insofar as the Kazakhs are landlocked and the first country through which the Silk Road extends as seen from Beijing.

Just one month later, in October 2013, the second, sea-based part of the OBOR vision was completed while Xi Jinping was visiting Indonesia, a crucial friend for China to have to not fall prey to a sea blockade in the future: 
President Xi proposed building a close-knit China-ASEAN community and offered guidance on constructing a 21st Century Maritime Silk Road to promote maritime cooperation. In his speech at the Indonesian parliament, $\mathrm{Xi}$ also proposed establishing the Asian Infrastructure Investment Bank (AIIB) to finance infrastructure construction and promote regional interconnectivity and economic integration.

(Xinhua 2015b)

Again, the choice of Indonesia does not seem random but rather perfectly logical. It is an island nation and, being situated on the south side of the Strait of Malacca Indonesia, is extremely important to China in terms of its reliance on commercial trade and delivery of resources such as oil via the major sea lanes from Europe, Africa and the Middle East to Northeast Asia. Associated with the Malacca Strait in particular is China's constant fear that other countries, especially the U.S., could decide to enforce a sea blockade at this hotspot, which would have detrimental consequences for its energy security and economic performance. As such, it makes perfect sense to use an official visit to Indonesia to announce the Maritime Silk Road of the OBOR initiative, since this is also the first country passed through via the sea route when leaving Chinese sovereign (maritime) territory, which extends to the southernmost parts of the SCS (i.e., Indonesia's shores). ${ }^{76}$

\footnotetext{
${ }^{76}$ For a full account of Chinese claims in the SCS and their implications, see, e.g., Gao and Jia (2013) and Kaplan (2015), respectively.
} 
The next important date in the chronology of the OBOR was another month later in November, when, for the first time in China, and for the first time not directly through a speech of President Xi but through a CCP party organ, "[t]he Third Plenary Session of the 18th Central Committee of the Communist Party of China called for accelerating infrastructure links among neighboring countries and facilitating the Belt and Road initiative" (Xinhua 2015b). Whereas the initial focus had been on economic cooperation, the infrastructural aspect was more highlighted now. At another domestic event, President Xi fused these two aspects (infrastructure and economic advancement), calling for the OBOR "to promote connectedness of infrastructure and build a community of common interests" (Xinhua 2015b).

The first bilateral agreement associated with the OBOR was between China and Russia and followed a few months later, in February 2014, when "Xi and his Russian counterpart, Vladimir Putin, reached a consensus on construction of the Belt and Road, as well as its connection with Russia's Euro-Asia Railways" (Xinhua 2015b). Interestingly, this was in the midst of the Ukraine Crisis, just a few weeks before Russia's move to annex Crimea in March 2014 and the above-mentioned Sino-Russian agreement in May 2014. Strategically, gaining Russia's cooperation in the OBOR was very important, as Russia has historically enjoyed a high level of influence over Central Asia and extended influence in the Middle East and Eastern Europe, all of which are integral parts of the OBOR.

In March 2014, in his second annual report on government work, Prime Minister (PM) Li “called for accelerating Belt and Road construction (...) and for balanced 
development of the Bangladesh-China-India-Myanmar Economic Corridor and the ChinaPakistan Economic Corridor" (Xinhua 2015b). In this instance the perhaps un-altruistic posture also comes to bear, especially because it is a report meant less for the outside world than for domestic legitimacy, in which Li spoke of " $[\mathrm{u}]$ shering in a new phase of China's opening to the outside world and ensuring its high standard performance" (Xinhua $2014 d) .{ }^{77}$

In the second instance after the February bilateral agreement with Russia, China agreed to a specific project with its Kazakh neighbor state in May 2014. The project, a logistics terminal (which is fitting with the theme of the Silk Road as a trade route) was to be:

jointly built by China and Kazakhstan [and] went into operation in the port of Lianyungang in east China's Jiangsu Province. The terminal, with a total investment of 606 million yuan (98 million U.S. dollars), is considered a platform for goods from central Asian countries to reach overseas markets.

(Xinhua 2015b)

At around the same time, the first specific multilateral manifestation of the OBOR-the AIIB, which will be further discussed below as an economic policy case-began to come about. Whereas China's general diplomatic preference is bilateral negotiation and

\footnotetext{
${ }^{77}$ See also China (2015c), Xinhua (2014f) and Salidjanova and Koch-Weser (2014).
} 
agreement, this multilateral aspect of the OBOR is noteworthy and likely will act as a catalyst for projects in the decades to come.

Next, at the occasion of the November 2014 Asia-Pacific Economic Cooperation (APEC) summit, which was hosted by China and took place in Beijing,

President Xi announced that China will contribute 40 billion U.S. dollars to set up the Silk Road Fund. (...) Xi announced that the fund will be used to provide investment and financing support for infrastructure, resources, industrial cooperation, financial cooperation and other projects in countries along the Belt and Road.

(Xinhua 2015b)

This marked the second multilateral instance in which the OBOR was promoted and announced, although only a minority of APEC countries - some Southeast Asian states (Indonesia, Malaysia, Vietnam, Singapore, Thailand, Philippines) and Russia-even qualify for the OBOR initiative. ${ }^{78}$

In early December 2014, “Thailand approved a draft memorandum of understanding between Thailand and China on railway cooperation" (Xinhua 2015b), marking the third specific bilateral agreement in the OBOR and the first with a state that

\footnotetext{
${ }^{78}$ Laos, Myanmar, or Cambodia are not APEC members, as they do not boarder the Pacific.
} 
does not share a direct border with China (although, if one subscribes to the Chinese understanding of the SCS, they do share maritime borders). Nevertheless, despite China pushing for a better sea route with the maritime Silk Road in OBOR, the improved railway connection with Thailand may be seen as a hedging strategy by China against the worstcase scenario of a U.S.-led maritime blockade of the Malacca Strait. In such a case, shipments from the Middle East could be delivered on either Burmese or Thai Indian Ocean ports and forwarded by rail to China, possibly via Laos. Later in December 2014, "[t]he Central Economic Work Conference sketched out priorities for the coming year, which include[d] the implementation of [the] Belt and Road initiative" (Xinhua 2015b) ${ }^{79}$

In early February the following year, at a special OBOR meeting, Zhang Gaoli, a high-ranking CCP official (who, among other functions, is also part of the Politburo Standing Committee), "sketched out priorities for the Belt and Road initiative, highlighting transportation infrastructure, easier investment and trade, financial cooperation and cultural exchange" (Xinhua 2015b). As far as the implementation and coming-together of the OBOR in its entirety, Zhang

highlighted the importance of environment protection and social responsibility in building the Belt and Road. Countries along the routes should increase communication and consultations and give full play to

\footnotetext{
${ }^{79}$ For more information about the 2014 Central Economic Work Conference, see Tiezzi (2014c) and Xinhua (2014e).
} 
multilateral, bilateral, regional and sub-regional cooperation mechanisms and platforms to seek common development and prosperity, Zhang said.

(Xinhua 2015l)

In his third annual government work report in March 2015, PM Li Keqiang gave assurance that "China will move more quickly to strengthen infrastructure with its neighbors, simplify customs clearance procedures and build international logistics gateways" in the coming year (Xinhua 2015b). ${ }^{80}$ Taking stock of the OBOR initiative thus far, Li found that:

China has been participating actively in establishing multilateral mechanisms and writing international rules. We have made steady progress in developing relations with other major countries, entered a new phase in neighborhood diplomacy, and made new headway in our cooperation with other developing countries. Notable progress has been made in conducting economic diplomacy. Progress has been made in pursuing the Silk Road Economic Belt and 21st Century Maritime Silk Road initiatives; preparations have been made for establishing the Asian Infrastructure Investment Bank, and the Silk Road Fund has been set up. China is engaging

\footnotetext{
${ }^{80}$ See also Xinhua (2015m).
} 
in more exchanges and cooperation with other countries, and is increasingly recognized as a major responsible country on the international stage.

(Xinhua 2015m)

Working against the vagueness of the OBOR thus far, Li sought to define it in further detail, stating that the government:

will work with the relevant countries in developing the Silk Road Economic Belt and the 21st Century Maritime Silk Road. We will move faster to strengthen infrastructure connectivity with China's neighbors, simplify customs clearance procedures, and build international logistics gateways. We will work to build the China-Pakistan Economic Corridor and the Bangladesh-China-India-Myanmar Economic Corridor. We will make China's interior and border areas more open to the outside world, promote the innovation-driven development of economic and technological development zones, and upgrade both border and cross-border economic cooperation areas. We will work actively to develop pilot free trade zones in Shanghai, Guangdong, Tianjin, and Fujian, and extend good practices developed in these zones to the rest of the country so that such zones become leading reform and opening up areas, each with its own distinctive features.

(Xinhua 2015m) 
Following the move from the proposal and planning stage of the OBOR to the first manifestations as described above, the western media started to report more on the initiative as well. As comparisons associated with reporting on the OBOR to the postWorld War II U.S. Marshall Plan grew in number,

Chinese Foreign Minister Wang Yi dismissed [such] comparisons of the initiative to the U.S.-sponsored Marshall Plan. The initiative is 'the product of inclusive cooperation, not a tool of geopolitics, and must not be viewed with an outdated Cold War mentality,' Wang said, adding that China's diplomacy in 2015 will focus on making progress on the Belt and Road initiative.

(Xinhua 2015b)

In March 2015, the OBOR was first put into a proper government programmatic document. The three government agencies working on it were:

[t]he National Development and Reform Commission, Ministry of Foreign Affairs and Ministry of Commerce[, which] jointly released an action plan on the principles, framework, and cooperation priorities and mechanisms in the Belt and Road Initiative after President Xi Jinping highlighted the strategy the same day while addressing the opening ceremony of the 
2015 annual conference of the Boao Forum for Asia (BFA)[, offering further] insight in the China-initiated program's vision and endeavors.

(Xinhua 2015b)

While giving the OBOR initiative more structure and detail, the document still left the necessary wiggle room for interpretation and maneuvering in the future; nevertheless, it was intended to function as a roadmap for the development of the OBOR as an umbrella diplomatic initiative. The established powers' concern that China was suggesting to rewrite the currently liberal, U.S.-led international order by the OBOR initiative, which could turn out to be a revisionist agenda, was addressed insofar as the document mentioned that it would be:

in line with the purposes and principles of the UN Charter. (...) [It] is harmonious and inclusive. It advocates tolerance among civilizations, respects the paths and modes of development chosen by different countries, and supports dialogues among different civilizations on the principles of seeking common ground while shelving differences and drawing on each other's strengths, so that all countries can coexist in peace for common prosperity. (...) It will abide by market rules and international norms, give play to the decisive role of the market in resource allocation and the primary role of enterprises, and let the governments perform their due functions. (...) It accommodates the interests and concerns of all parties involved, and seeks a conjunction of interests and the 'biggest common denominator' for 
cooperation so as to give full play to the wisdom and creativity, strengths and potentials of all parties.

(Commission 2015)

While this is naturally meant to sound non-threatening to the stakeholders of the current international order, it shows the way of handling international relations that is practiced in Association of Southeast Asian Nations (ASEAN); that is, the finding of the 'biggest common denominator.' In line with this, the document also included the kind of rules and norms that China likes to uphold, such as "the Five Principles of Peaceful Coexistence: mutual respect for each other's sovereignty and territorial integrity, mutual non-aggression, mutual non-interference in each other's internal affairs, equality and mutual benefit, and peaceful coexistence" (Commission 2015).

The necessary wiggle room mentioned above can be seen in statements on the geographical dimension of the OBOR initiative, in that "[i]t covers, but is not limited to, the area of the ancient Silk Road. It is open to all countries, and international and regional organizations for engagement, so that the results of the concerted efforts will benefit wider areas" (Commission 2015). Although unlikely, this technically implies that Oceania, Latin and North America could become part of the OBOR. Arguably, this statement might have been included simply to avoid making the OBOR initiative seem like an exclusive club that locks out nations with which China has friendly relations. The document still does not give a timetable of what is to be done when; instead, it focuses 
mainly on emphasizing the OBOR initiative's message of bringing together the European, African, and Asian continents via better infrastructural and logistical connection.

\section{Localization of the Case in Terms of Honor and Legitimacy}

The factor of honor, and by extension status, prestige, recognition and reputation, is deeply ingrained in the OBOR as it relates to both internal and external legitimacy. The OBOR calls to mind the far-reaching influence that the Chinese Empire enjoyed for centuries in ancient, medieval and early modern times. The Silk Road—both on land and on sea—stood as a symbol of the civilizational advancement of China at the time. Much of this erstwhile splendor is related to the nature of the traded luxury products from China, such as porcelain, tea, spices, or silk. As such, this calls into mind the prestige associated with China's advancement at the time. Thus, the function of the OBOR is twofold. On the one hand, it will ameliorate opinions of adjacent states' decision-makers away from seeing China as a threat and toward seeing China as a regional hegemon that is both interested in the benefits to its own population and interested in helping others to develop. On the other hand, it promotes the rise in status that China is seeking to achieve, as this project is essentially unprecedented in Eurasia.

The external legitimacy sought through the OBOR works not only to enhance China's reputation outside the spheres of the Middle Kingdom (especially immediate neighbors) but also to internally strengthen the foothold of the CCP with the 
domestic population. Overcoming the 'Hundred Years of National Humiliation' is central to the CCP's strategy to use nationalism for its rectification of home rule. In essence, if the OBOR becomes a long-term success and sustainably improves China's international reputation and prestige, this would be a return to the role imperial China enjoyed before the onset of the First Opium War in 1939, in which it was able to actively steer international affairs, mainly with its tributary system vehicle.

Importantly, the OBOR initiative not only means that China is willing to engage the international community responsibly (in a way that it half-altruistic and halfselfish) but also that China is aiming to return to the status quo from before the First Opium War and the following Hundred Years of Humiliation and start dictating the rules and norms of international relations again rather than merely having to follow them. While to some, especially the erstwhile aggressors associated with the humiliation complex (i.e., Japan and the West), this may seem like an action of a revisionist power, to many nations of the Third World, especially those that do not necessarily have to fear the rise of China as direct neighbors, this may be seen as a good thing in terms of external legitimacy. More importantly, internally, China gains prestige with its own population in going against the world order, as it was established first by the British global hegemon and then further advanced by the U.S. global hegemon after World War II. Thus, while being mainly a case of external legitimacy, the case of OBOR also contains a layer of internal legitimacy, which is associated not only with the OBOR's promised economic stimulus for the Chinese market but also, and importantly, with its diplomatic dimension and the prestige it brings. 


\title{
Determining Convergence with or Divergence from PD Grand Strategy
}

\author{
Defense of territorial integrity
}

If China can make in-roads on the infrastructure of potentially weak developing states in China's periphery, helping them economically in general and (depending on how far the OBOR initiative will go) possibly integrating the region further, this can help to keep peace in Asia, especially around China's borders. Ultimately, this may add stability to governments of weaker states, which in turn can help China to maintain national unity and have safer border security. Following from this, China clearly converged with its PD grand strategy here (see table 3 for a visualization of convergences and divergences).

Increase of national power

The OBOR would put China at the center of a thriving region, which would certainly give China leverage over the participant states. What kind of power increase will be involved remains to be seen. International power is traditionally defined as making another state do what you want them to do when it is different from what they initially wanted (first and second faces of power), as well as shaping other nations' initial preferences and ideas via institutions or ideologies. ${ }^{81}$ The OBOR would be an increase in

\footnotetext{
${ }^{81}$ The 'first face of power': "Payment or economic inducement to do what you initially did not want to may seem more attractive to the subject, but any payment can easily be turned into a negative sanction by the
} 
power according to the first face of power (i.e., via buying nations off and/or threatening to take away economic inducements). Depending on the extent of the OBOR, it may also turn out to be a power increase according to the second face of power (i.e., via agenda setting). Lastly, in the event that the OBOR turns out to have the sort of subtlety of the medieval tributary system or modern day U.S.-American orthodox capitalism and democracy, China may also gain power via the third face of power (i.e., shaping other nations' initial preferences and ideas).

\section{Anti-hegemonism}

For those who see the OBOR as a twenty-first century Chinese equivalent to the U.S. Marshall Plan of the post-World War II period, the OBOR may appear to pose a potential challenge to the U.S.-led world order as it exists now and as it is institutionalized in the International Monetary Fund (IMF), World Bank (WB), WTO and UN, among other institutions. It is no secret that:

implicit or explicit threat of its removal. (...) Moreover, in unequal bargaining relationships, (...) a paltry 'take it or leave it' payment may give the [LDC] little sense of choice" (Nye 2011, 12). The 'second face of power': "If ideas and institutions can be used to frame the agenda for action in a way that make others' preferences seem irrelevant or out of bounds, then it may be possible to shape others' preferences by affecting their expectations of what is legitimate or feasible. Agenda-framing focuses on the ability to keep issues off the table, or as Sherlock Holmes might put it, dogs that fail to bark" (Nye 2011, 12). The 'third face of power': "[I]deas and beliefs also help shape others' initial preferences. (...) [One] can also exercise power over [another] by determining [their] very wants. [One] can shape [others'] basic or initial preferences, not merely change the situation in a way that makes [them] change [their] strategy for achieving [one's] preferences. (...) If [one] can get others to want the same outcomes that [one] wants, it will not be necessary to override their initial desires" (Nye 2011, 13). 
China's growing economic power and ongoing concerns about being marginalised by the United States as a result, have changed (...) views in Beijing. China now holds the largest reserves of foreign currency by a single actor, and has expressed interest in developing greater commercial diplomacy, meaning the ability of transforming wealth into diplomatic power.

(Lanteigne 2016, 94)

The AIIB is seen as a first harbinger of institutional change, also fueling speculations about China's future intentions to challenge global governance. In their view, China will want to create a new version of its tributary system at the height of its past power between the Tang dynasty and the High Qing. Thus, although the OBOR seems to be beneficial to nations that will subscribe to it (just as the Marshall Plan has been to many European nations) those that consider China to be exploitative and assertive see it as selfishly motivated.

On the other side are those that see a benign China with good intentions for the region, or at least with mixed motives that may benefit others via selfish behavior. In exchange for a more stable region—possibly with military bases abroad, as well as infrastructure projects for its corporations-China achieves better security itself and possibly legitimacy to become the next global (or at least the Eurasian regional) hegemon, while others can develop economically and profit from China in one way or another. 
In sum, in the event that the OBOR is meant to drive the U.S. out of Asia and place China in its former role, this motive should be seen to converge with the norm of anti-hegemonism in China's PD grand strategy. On the other hand, in the event that China's intentions are to be very far-reaching and ultimately to establish a hegemony, forcing others into quasi-subjugation (whether subtly, as in the erstwhile tributary system, or not), then this would be in contradiction to China's own anti-hegemonism norm and would therefore be seen to diverge from the PD grand strategy.

Maintenance of favorable economic markets

The factor of keeping favorable economic markets is an important one in the case of the OBOR. As Reeves writes, the OBOR:

[I]s equally reliant on economic exchange as a means of increasing stability. In its wider application, the One Belt, One Road concept includes China's provision of finance through the 2015 establishment of the Asian Infrastructure Investment Bank (AIIB) and China's trade and investment schemes toward Central and South Asia through the Silk Road Economic Belt and Maritime Silk Road, respectively.

(Reeves 2015, 15)

Since a number of investments in the region are associated with this initiativeinvestments which can not only help China's neighbors but also help China's own economy 
as a kind of economic stimulus - this can be considered to perfectly converge with the PD grand strategy.

International responsibility

At first glance, trying to create more economic growth for and investing in neighboring states shows international solidarity on the part of China, and thus international responsibility as one of the preeminent powers in Asia. Ultimately, it remains to be seen how self-serving the OBOR will be to Chinese interests; nonetheless, if it becomes anything like the U.S. Marshall Plan (which is the expectation of many), then this also converges with the PD grand strategy in terms of being a so-called 'responsible stakeholder.'

Avoidance of 'China threat' misperception

On the one hand, the extent of the OBOR does raise some eyebrows in the eyes of decision-makers, particularly in Vietnam, the Philippines, Japan, and India, and perhaps even in Russia, where Putin had his own vision of a Eurasian free trade zone that would be in competition with China's. "The U.S. is already very suspicious of China's long-term strategic intentions in the South China Sea and many European countries are also uneasy about China's expanding influence into the EU" (Chen 2015). 
Those who view the OBOR critically fear that China is planning to establish a quasi-tributary system over vast parts of Asia and therefore a modern-day suzerainty over many weaker states. Such an attempt to lead so many states, even reaching into the hinterland of Europe where China has no historically precedented foothold (excluding the Mongol conquests of the twelfth and thirteenth centuries), would call for China to grasp hegemony and therefore be perceived as threatening. This would therefore naturally be divergent from the PD grand strategy.

On the other hand, rather than seeking to 'flex its muscles' by suggesting the OBOR initiative, China may intend to go specifically against the 'China threat' misperception, as outlaid in the PD grand strategy. The fact that investing so heavily in the region can be interpreted as altruistic behavior (even though China is likely to benefit more than the OBOR participant nations) may ameliorate some foreign decision-makers' perception of China rising and should therefore be considered as converging with the PD grand strategy.

Increasing China's international reputation

Clearly, the OBOR increases China's reputation, since it is a very ambitious program aimed at unifying many nations in the pursuit of economic growth. Moreover, the OBOR hints heavily at the more glamorous times of China's history, when the Silk Road on the land route and the Maritime Silk Road were major trading paths and the Middle Kingdom was the nation with the highest GDP globally. 


\begin{tabular}{|c|c|}
\hline Factor in PD & Convergence / Divergence \\
\hline Defense of territorial integrity & $\begin{array}{l}\text { Convergence } \\
\text { (infrastructure investment helps keep peace and } \\
\text { regime stability affecting China's unity) }\end{array}$ \\
\hline Increase of national power & $\begin{array}{l}\text { Convergence } \\
\text { (leading economic growth in the region can act } \\
\text { as a sort of 'buy-off' coming from China) }\end{array}$ \\
\hline Anti-hegemonism & $\begin{array}{l}\text { Convergence \& Divergence } \\
\text { (convergence: OBOR as challenge to the U.S.- } \\
\text { led world order; divergence: nations in China's } \\
\text { neighborhood fearing influence) }\end{array}$ \\
\hline $\begin{array}{c}\text { Maintenance of favorable economic } \\
\text { markets }\end{array}$ & $\begin{array}{c}\text { Convergence } \\
\text { (economic stimulus for own economy, via } \\
\text { construction abroad and more exports there) }\end{array}$ \\
\hline International responsibility & $\begin{array}{c}\text { Convergence } \\
\text { (investing in infrastructure of neighbors shows } \\
\text { international solidarity) }\end{array}$ \\
\hline $\begin{array}{l}\text { Avoidance of 'China threat' } \\
\text { misperception }\end{array}$ & $\begin{array}{l}\text { Convergence \& Divergence } \\
\text { (convergence: investment is something } \\
\text { positive; divergence: suspicions about China's } \\
\text { regional hegemonic ambitions) }\end{array}$ \\
\hline $\begin{array}{c}\text { Improving China's international } \\
\text { reputation }\end{array}$ & $\begin{array}{c}\text { Convergence } \\
\text { (very ambitious program; } \\
\text { hints at China's glamorous times in history) }\end{array}$ \\
\hline
\end{tabular}

Table 3: Divergence from or convergence with PD in the case of China's OBOR diplomacy.

\section{Alternative Explanations}

There is little doubt that honor-and by extension status, prestige, reputation and recognition-play a determining role in the development and eventual realization of the OBOR. Naturally, China has been undertaking such infrastructure and other development projects bilaterally in negotiation with individual nations, and most 
likely it would have continued with this practice of bilateral projects with or without OBOR. As such, OBOR can be seen as a skillful diplomatic move in pooling projects that would have happened either way.

Since the OBOR calls on the historical memory of tributary relations and Silk Road trade, the four different deeper meanings of the tributary system suggested by scholars can be partially considered as alternative explanations. The tributary system has been described as: 1) simply an economic trading place, 2) merely a symbolic diplomatic exercise without a tangible purpose besides the symbolic status-giving and -receiving gestures, 3) an expression of the realpolitik in a system in which China guaranteed security in exchange for suzerainty over adjacent kingdoms' territories, and 4) an alliance (implicitly against the constant threat of freely roaming nomads) on the basis of real equality which was interpreted and communicated domestically in different ways by every kingdom involved.

Otherwise, economic interest and security concerns certainly matter here, too. Making the periphery more secure by helping it develop economically, and therefore giving back to the respective governments of adjacent nations, will contribute to China's own domestic security and survival as a nation-state, especially because the CCP is preoccupied with the Tibetan, Uyghur and Mongolian peripheral autonomous regions. 


\section{Conclusion of Case Analysis}

The case of the OBOR shows mostly converging behavior, with only minor doubts on the points of anti-hegemonism and the perception of China as a threat. Overall, the more outward-focused OBOR initiative met all factors of the PD grand strategy, and therefore China did not diverge from it. Since this grand strategy manifestation perfectly converges with the PD grand strategy, and since it is mostly meant to be outward-looking and peaceful, it is not too far-fetched to say that the lion's share of the OBOR is related to honor and external legitimacy. However, as mentioned earlier, there are minor layers of internal legitimacy as well.

These layers of internal legitimacy may be divided into two types. One the one hand, there are the economic benefits China will likely gain from the OBOR in the short term, as well as those to be gained in the long term. On the other hand, there is the international diplomatic prestige to be gained, which will also have effects at the domestic level through maintaining and creating jobs and projects for Chinese construction companies for the necessary infrastructural work over the next decades of the OBOR. This kind of altruistic-seeming economic stimulus for China's own market was typically undertaken in the past in bilateral projects that functioned as quasi-foreign aid by China to the recipient country. All the OBOR really does — albeit impressively and with much pomp and circumstance - is to harness China's diplomatic actions into a larger cross-regional initiative. Related to this short-term gain for China is the general longer-term advantage of maintaining a beneficial regional and global market for Chinese exports on which China 
still heavily depends. In theory, better infrastructure and more trade, especially with China, will help to develop the recipient country as well, making them wealthier and thus increasing the potential for China to export more to that neighbor.

In addition, the diplomatic international prestige that China has been and is bound to receive externally from the generous OBOR initiative also has effects at the domestic level. This engagement with the international community is a reflection of China's risen status as a great power, and the prestige and recognition associated with the positive feedback from the affected states certainly embolden the pride in the hypernationalists among the Chinese. The whole concept of the OBOR also is very intelligently crafted by the CCP to avoid including any of the so-called 'others' of the past decades (i.e., either the U.S. or Japan). It does include some European nations that were aggressors within the timeframe of the humiliation complex; however, from the geographical illustrations of the OBOR, ${ }^{82}$ it can be seen that this is not emphasized much, since the most prominently marked European end points are Athens, Venice, Rotterdam, and Moscow. If one takes into account "'historical memory,' which only lasts about a hundred years" (Kang 2010, 167), then it is reasonable to narrow down the arch-enemies of China to the U.S. and Japan. Finally, yet another connection of the international to the domestic is along the lines of the prestige and status which the tributary system helped internally legitimize China in the Middle Ages. Likewise, not only an economic boost from the OBOR to the

${ }^{82}$ See Appendix, illustration 1. 
Chinese market but also a boost in stature vis-à-vis the West and Japan is likely to be welcomed in terms of legitimacy on the home front.

Nevertheless, it is external legitimacy that is central to the OBOR, which is surely the main reason why the initiative is peaceful and perfectly converges with the PD grand strategy while still serving some domestic purposes. Also, this helps to overcome the humiliation complex, since China is aiming to restore its pre-1839 splendor. The fact that the Chinese appear overly generous with the OBOR and promise billions as rewards to both adjacent and remote nations certainly fits the definition of being (or aiming to become) a regional, if not supra-regional, hegemon. The above-mentioned fact that neither Japan nor the U.S. are (so far) part of the concept also additionally supports this objective. The recognition with which participant nations acknowledge Chinese leadership (and monetary buy-offs) is clearly related first and foremost to honor and external legitimacy, although the cultural drivers of fear (more peripheral security for China) and interest (economic stimulus for home economy and possibly more exports to more developed neighbors) are present here as positive side effects.

In the same vein of external legitimacy, there is a strong reference to the 'good times' in China's imperial history of tributary relations and a Silk Road trade system in which China made huge profits with luxury goods. The choice of the name for the OBOR initiative shows clearly that it is, at least partially, a project with an aim of increasing status. Other such undertakings (e.g., the geo-economic counterpart to the U.S.'s Trans-Pacific Partnership [TPP], the China-led RCEP [Regional Comprehensive Economic Partnership]) 
are much more neutral and less loaded with history; as such, they are perhaps less intended than the OBOR to cater to the needs for honor and status.

In sum, there is little to be said regarding the negative or assertive side of the OBOR, apart from some hyper-sensitive doubts of neighboring states about China aiming for hegemony or being a threat. Clearly, if such goals exist, then the CCP is making a statement by wanting to secure the approval of relevant nations via buying them off with promised rewards rather than forcing them with military threats into doing what China wants. Given that all of this activity (buy-offs, infrastructure projects as foreign aid, bilateral agreements with peripheral nations to increase security, etc.) has increased in the past decade and would have occurred with or without the OBOR initiative diplomatic umbrella project, one can argue with relative certitude that this diplomatic move is meant to increase stature and therefore mainly external legitimacy. 


\section{WITHIN-CASE STUDY GROUP TWO: ECONOMIC POLICY}

The axiom that independent states will by all possible means resist losing their independence will inevitably be expressed in the only way that the impossibility of large-scale war still allows, by 'geo-economic' means - the logic of strategy in the grammar of commerce.

(Luttwak 2012, 99)

\section{Case Selection and Classification}

No doubt the following two cases are not the only cases which would lend themselves to an analysis of China's economic policy as a manifestation of its grand strategy in the selected time frame. China's REE export restrictions in 2010 and its proposal for and eventual foundation of the AIIB after 2013, on the one hand, were highly discussed by the media and therefore can be considered salient cases for economic policy_ or at least two of the most salient cases in the time frame - and, on the other hand, fulfill the case selection standards as one case pertains to internal and the other to external legitimacythe fourth grand strategy design input besides those of the case study groups (economic, military, and diplomatic policies/strategies). 
The 2010 REE export restrictions should clearly be classified as speaking to internal legitimacy ${ }^{83}$ Export restrictions in general are a protectionist move in our global market -impeding free trade. In the current international system, as championed by the U.S., such restrictions are frowned upon as going against the integration of markets. Thus, a presumption that such restrictions speak to external legitimacy is ungrounded. They are mainly interpreted as an action against Japan, China's ex-conqueror, arch-enemy, andsome would say-China's 'Other' against which it identifies. By catering to the population's deep-seated enmity, the Chinese government increases its domestic, internal legitimacy in the absence of general elections for the national parliament. ${ }^{84}$ The Chinese population is also quite thin-skinned when it comes to the government spending the hardearned balance-of-trade surplus in foreign aid while suggesting that China itself is a developing country.

The undertaking to propose and found the AIIB and endow it with a multibillion dollar grant can be identified as part of the economic policy which is meant to project China internationally. China's spending money and effort on states in Asia, its

\footnotetext{
${ }^{83}$ There was also an earlier case of export restrictions on "eight raw materials used as inputs in the steel, aluminum and chemicals industries [which the WTO had already condemned]" (Pruzin 2014). However, since this case was not as intertwined with China's security strategy and diplomacy as the case of the REEs (plus Tungsten and Molybdenum) was, it was not considered here. For further in-depth analyses of the REE export restrictions, see, e.g., Ma (2012) and Morrison and Tang (2012).

${ }^{84}$ In past years, elections have been introduced for some local level, low-stakes political positions. This is, of course, nowhere near the level of the democracy which one could witness elsewhere, as the CCP may still pre-select candidates and the like. Still, this is a first step which can lead to more democracy in higher levels, up to the national level, in the future.
} 
neighbors, should be considered an aspect of external legitimacy. However, internal legitimacy also plays a role here; (i.e., indicating to the local population that China is rising in status to the extent that it spearheads an initiative to help adjacent countries which are less well off; this would speak to the local cry for China to return to its glorious past in terms of status). The other internal component associated with the AIIB is supporting states with infrastructure investment to help support China's own domestic economy. This is accomplished by maintaining a favorable economic environment and international environment in terms of economic, diplomatic, and military dimensions. Also, China invests in other countries' infrastructure in the same way it does, for example, in Africa: by bringing Chinese labor there, having Chinese (state-owned) companies carry out the project, and thus have the money return to China no matter what. For both points, this would mean that the AIIB is merely a selfish stimulation of China's own economy. However, the above-mentioned sensitivity of the local population speaks against this maneuver being solely meant for internal legitimacy. Thus, the AIIB is a dual-aspect case which speaks to both external and internal legitimacy.

Even so, for the most part, the AIIB is not subject to media reporting, which suggests that it is a domestically motivated initiative. The rhetoric of the Chinese government also does not offer such interpretation. In addition, nobody expects China to be a selfless Samaritan with purely altruistic intentions - especially people who know how China is set up internally. Nevertheless, China offers a great program for Asian countries lacking in infrastructure, of which there are many, including Afghanistan, Nepal, Mongolia, Laos, and the DPRK. The international community has long pushed for China to become 
a more "responsible stakeholder," as Zoellick $(2005, \mathrm{x})$ puts it. This new international organization also indicates that China intends to transport its own values outward: In the case of the AIIB, this is the Beijing Consensus, which provides for loans to developing countries in need without any strings attached (especially democratization, privatization, liberalization, or Westernization in general). That the initiative elevates China's prestige domestically and internationally is most important in the selection of this particular case.

Other relevant cases for this category include China's endeavor to create the RCEP which comprises the ASEAN and the non-ASEAN countries which already have free trade agreements (FTAs) with ASEAN. This would be a case for the external legitimacy dimension; however, it is not as fitting an example as the AIIB since many observers see the RCEP as a potential free trade area which would counter the U.S.-led TPP free trade area. The AIIB is more unanimously beneficial to the international community and, therefore, works better as a case of external legitimacy in addition to illustrating economic policy. Also, while the AIIB has been already founded, the RCEP and the TPP remain hypothetical initiatives.

Several bilateral economic agreements could also have made nice cases, like that between Russia and China in 2014, which mainly concerned the supply of natural resources from Russia to China, or the Sino-Swiss FTA of 2014. Both these agreements are manifestations of China's grand strategy on the economic dimensions, but they are not as far-reaching and important as the chosen cases. Also, the legitimacy dimension is not clearly internal or external at first glance. 
In addition, China's long-standing and continuing artificial undervaluation of its Renminbi currency is a clear case pertaining to internal legitimacy because it is an economic tool which is in China's favor, although criticized by the many countries with which it trades. ${ }^{85}$ Another reason for not choosing this as one of the cases is that this is a bit dated; while China's Renminbi (RMB) is still artificially undervalued, it is going in the direction of less and less undervaluation rather than more. Also, "[i]n its 2011 report, the IMF [International Monetary Fund] declared the RMB to be undervalued by a range of 323 percent" and, therefore, changed its opinion on the RMB to "only "moderately undervalued"” (Henry 2012, x). "Finally, some experts note that China's central bank wants to let the yuan gradually appreciate against the dollar anyway, but its Commerce Ministry (which represents interests of exporters and manufacturers) would rather the value of the yuan remain where it is" (Balaam and Dillman 2013, 172). In sum, there are many reasons not to choose this example - at least for the time frame starting in 2009. Still, it is an economic example that has received considerable attention in the media and definitely worth mentioning.

Finally, China's lending behavior during the global financial crisis since 2008 and the eurozone crisis since 2010 are good examples of economic policy manifestations of China's grand strategy pertaining to external legitimacy. Although many Western nations were in vulnerable positions after the recent crises, China was ready to

\footnotetext{
${ }^{85}$ See, for example, Balaam and Dillman (2013), 172. They refer to this behavior as 'currency manipulation' rather than 'artificial undervaluation.'
} 
help with buying bonds — when nobody else really wanted them — and partially Chinese private companies also stepped in to take over Western companies that struggled after the crises. ${ }^{86}$ Due to the high dependence of the Chinese economy on exports and, therefore, world economic growth, it does make sense for the Chinese government to, e.g., buy foreign government bonds; however, this is surely not the most popular way to spend the monetary reserves and citizen tax money that China has in abundance. Thus, this is a relatively clear example of external legitimacy.

\section{The Rare Earths Export Restrictions ${ }^{87}$}

\section{Introduction of the Case}

In 2010, China significantly diverged from its grand strategy of PD when it enacted export restrictions of REEs,${ }^{88}$ which effectively amounted to an embargo against

\footnotetext{
${ }^{86}$ See, for example, Norrlof and Reich (2015).

${ }^{87}$ An adapted version of this sub-chapter was published as part of a research article in Tamkang Journal of International Affairs, vol. 20, no. 1 (July 2016), pp. 1-60.

${ }^{88}$ REEs are "a set of 17 chemical elements in the periodic table that include 15 lanthanides (lanthanum, cerium, praseodymium, neodymium, promethium, samarium, europium, gadolinium, terbium, dysprosium, holmium, erbium, thulium, ytterbium, lutetium), as well as scandium and yttrium" (Pruzin 2014). The export restrictions enacted by China included also Tungsten and Molybdenum, which are outside of the earth elements category but rather are metals.
} 
Japan sanctioning its behavior in an incident with a Chinese captain taken into custody by the Japanese authorities in the ECS:

On September 7, 2010, a Chinese fishing boat collided with Japanese patrol vessels near the disputed islands known to the Chinese as Diaoyu and to the Japanese as Senkaku. The Chinese boat's captain and his crew were detained by the Japanese coast guard and taken to Japan, over the Chinese government's strenuous objections. In response, China blocked a number of rare earth exports to Japan, and arrested four Japanese nationals for allegedly trespassing in restricted Chinese military areas.

(Pillsbury 2015, 204)

It was by no means an embargo outspokenly instituted against the Japanese. Rather, because Japan was the main importer of REEs necessary for many products in the semiconductor or automobile market, this general limitation of exports effectively amounted to an embargo against Japan.

These actions by China against Japan, in particular, must be seen within the context and knowledge that China has a quasi-monopoly on the production and export of REEs in the world:

The one commodity where China is accused of mercantilist and monopolist behavior is in so-called rare earth elements, a category of seventeen metallic 
elements used in high-technology applications as wide ranging as automobile catalytic converters and hybrid engines, compact discs, cell phones, computer display screens, communication systems, missile guidance systems, laser-guided weapons, and high-temperature superconductivity. China is the world's leading producer of rare earths, controlling 95 percent of existing global production and producing more than 120,000 tons in 2010 . What is controversial is that China has restricted exports of domestically mined rare earths, which (given its semimonopoly status) severely affects foreign manufacturers of high-tech equipment. ${ }^{89}$

(Shambaugh 2013, 173f.)

Before the 2010 incident, China had begun to implement a general export policy which was more beneficial to the prices it could obtain for REEs; as Shambaugh writes:

Beginning in 2009 China began restricting exports of a number of these mineral elements by substantially lowering preset quotas for exports to the European Union [EU]. As a result, the EU—-together with the United States and Mexico-filed a case with the World Trade Organization WTO] [arguing that China's near monopoly on production combined with its

\footnotetext{
${ }^{89}$ The 95 percent mentioned here are a lower estimate of what China is controlling in comparison to, e.g., Smith's estimate who asserts that "China produces about 97 percent of the global supply of rare earths" (Smith 2015b, 192).
} 
unilaterally restricted exports was discriminatory behavior violating WTO free trade rules by applying export quotas. In July 2011 the WTO agreed, ruling against China. China then denied it was intentionally restricting exports and manipulating the international market by arguing that its production and export quotas were appropriate and fair, and it appealed the ruling. In January 2012, China lost the appeal before the WTO Appellate Body. This was a prime example of China's state-dominated mercantilist trading practices bumping up against international regulators.

(Shambaugh 2013, 173-74) $)^{90}$

The case's further development saw the appeal to the WTO by the U.S., Japan, and the EU in 2012, China's losing the case in 2014, China's appeal of the WTO verdict shortly thereafter, and the rejection of the latter by the WTO in the same year. Since early 2015, the REE trade has been unrestricted, but by 2012, China had lost its leverage over Japan with this export restriction as Japanese demand decreased and Japan sought REEs elsewhere. ${ }^{91}$ The period during the WTO case more or less coincided with the

\footnotetext{
${ }^{90}$ Contrary to Shambaugh, Smith sees this process of export restrictions as having begun even prior to 2009: "Even before the 2010 incident, the Japanese government struggled to gain Chinese acquiescence in maintaining access to these rare earth minerals. Then in 2006 China began to impose quotas on its exports to ensure environmentally sound practices of extraction but also to ensure that its domestic manufacturers had priority access to them. Although Japanese government officials sought continued access to China's rare earths, Japan's quota has already been reduced, as have the quotas on exports to other nations, with China cutting its exports by half since 2005, from 65,580 tons to 31,130 tons in 2012" (Smith 2015b, 201f.). Indeed, 2005 was the origin of this quota system. See also, e.g., Yap (2015).

${ }^{91}$ See, e.g., Kyodo (2012).
} 
diplomatic ice age between China and Japan from late 2012 to late 2014, when the Senkaku/Diaoyu Islands dispute flared up again and tensions were high.

\section{Detailed Course of Events of the Case}

As mentioned earlier, the case had its origin in an area seemingly unrelated to economic policy, ${ }^{92}$ that is, the collision of a Chinese fishing boat with two vessels from Japanese coastal law enforcement on September 7, 2010. Japanese authorities seized the captain of the Chinese ship together with his crew as a consequence. Japan released the boat and 14 of the crew less than a week after the incident. Tokyo, however, kept Captain Zhan Qixiong in custody, where he remained pending investigation (Chang 2010). Even so, China expected Japan to immediately release its captured citizen and apologize for seizing him and his crew in the first place. Equally assertive was how China's behavior translated on the diplomatic level:

\footnotetext{
${ }^{92}$ This seems unrelated to economic policy apart from the fact that large quantities of fossil natural resources like oil and/or gas are said to be under the seabed in this area of the East China Sea-most prominently the Chunxiao gas field which is located Northeast of the Senkaku/Diaoyu islands and Northwest of Okinawa. With China contesting the territorial ownership of Japan, especially what concerns the Senkaku/Diaoyu Islands, this may be said not only to be a political or security-related concern but also related to China's economy and economic policy. In terms of the latter this would be mainly pertaining to China's energy security strategy, i.e., to augment the market and attain as many natural resources as possible to be in a position to fuel growth of its market for decades to come. Besides this potential existence of fossil resources, the fishing grounds near these islands are known to be very rich as well, and therefore can be considered valid to China's economy, too.
} 
Beijing's initial reaction was to issue a series of diplomatic protests, broadcast increasingly harsh statements from the Foreign Ministry, cut off ministerial-level contacts and refuse to go forward with a meeting this week between Chinese Premier Wen Jiabao and Japanese Prime Minister Naoto Kan on the sidelines of the opening session of the U.N. General Assembly.

(Chang 2010)

Besides these measures, "China has also detained four Japanese nationals on suspicion of violating a law protecting military facilities" (Inoue 2010, x). Japan, however, expected China to pay for damage to the vessels and issue an official apology for encroaching into Japanese waters:

[I]n September 2010, a Chinese fishing boat intentionally rammed two Japanese Coast Guard vessels near the disputed Senkaku/Diaoyu Islands, prompting Japanese authorities to detain the fishing boat's captain. Far from expressing embarrassment or offering an apology, Beijing instead demanded an apology for itself and flatly refused Japan's request to pay for the damage to the Coast Guard vessels. China also imposed a (temporary) ban on the export of rare earth metals to Japan, causing harm to the Japanese microelectronics industry.

(Lynch 2015, 156) 
According to Lynch, on September 23, 2010, China started to block REE exports to Japan. As a reaction to the arrest of the fishing boat captain, China ordered authorities to lengthen the customs processing time for all REE shipments to Japan, without officially admitting that such orders existed, of course: "[T]raders in Tokyo said China had blocked exports to Japan of key minerals by slowing down administrative procedures in ports in Shanghai and Guangzhou to prevent materials being loaded on ships" (AFP 2010). At this point, Forbes magazine's Gordon Chang went as far as calling this behavior "China's New Economic Warfare" (Chang 2010)—underlining the perceived assertiveness behind this action.

Japan released the captain on September 24, 2010, and China lifted the REE ban to Japan a few days later, "end[ing the] de facto ban on exports to Japan of rare earth minerals" (Inoue 2010). Still, China did not admit to ever doing anything to halt the REE exports to Japan and other nations, but in the context of the territorial dispute and the fishing boat incident, it was clear that China reacted to what it thought to be unacceptable on the part of Japan. However, the return of the captain to mainland China did not calm the situation - quite the opposite:

Zhan himself remained adamant that he had done nothing wrong. 'The Diaoyutai Islands are a part of China. I went there to fish. That's legal,' he said upon his return to China. 'Those people grabbed me - that was illegal.' China's government shared Zhan's stance[.] (...) Beijing considers Japan's 
Coast Guard patrols to be illegal, since China claims the disputed islands and surrounding waters as its territory.

(Tiezzi 2014d)

On September 30, 2010, China—via its National Tourism Administration— warned its citizens against traveling to Japan "after a group of Chinese tourists were attacked on a trip to Fukuoka" (Moore 2010). Protests had been ongoing on both sides of the ECS as a reaction to the fishing boat incident. Following this incident, Japanese "demonstrators rallied against China's claim to the [Senkaku] islands and delivered a note to China's embassy" in Tokyo (BBC News 2010a). Similarly, on October 17, 2010, China broke up protests by some of its citizens against Japan; anti-Japanese demonstrators had become violent and destroyed Japanese property and businesses. ${ }^{93}$ While Japanese PM Naoto Kan "told the Chinese authorities [that] (the demonstrations) were regrettable and strongly urge[d] (China) to ensure the safety of Japanese nationals and firms," the Chinese stayed stubborn on the issue (BBC News 2010a): "A Chinese foreign ministry spokesman[,] Ma Zhaoxu[,] said it was 'understandable that some people expressed their outrage against the recent erroneous words and deeds on the Japanese side[,]" but also that "patriotism should be expressed rationally and in line with law" (BBC News 2010a) ${ }^{94}$

\footnotetext{
${ }^{93}$ See BBC News (2010).

${ }^{94}$ While this seems to be a standard phrase from the Foreign Ministry, to suggest that patriotism - an emotion - should be expressed rationally seems very far from reality, though. These two, emotion or passion and ratio or reason, have been seen as opposites by many theorists, such as Karl von Clausewitz in his unfinished work On War, writing on his famous trinity of war, i.e., passion, reason, and chance. See Clausewitz (2012 [1832]).
} 
The process of negotiation between China and Japan was lengthy, as presumably intended from the Chinese side. As Smith writes,

[O]n October 19, the China Daily reported that the country would cut its total exports of rare earths by 30 percent in 2011 in order to 'protect overexploitation.' The following week, China's vice-minister of commerce, Jiang Yaoping, visited Tokyo to meet with METI Minister Ōhata. Ōhata repeated Japan's request that China ease its restrictions on the export of rare earths. On November 13, Minister Ōhata met with Zhang Ping, China's director of the Development and Reform Commission, on the sidelines of the Yokohama APEC Summit. The METI had initiated this meeting, which lasted for two and a half hours. Afterward, Zhang noted that the rare earth issue would be 'properly resolve[d] very soon.' The next day, Minister Ōhata announced that twenty-six of the twenty-seven companies surveyed by the METI reported that for the first time since the trawler incident, they could see 'signs of improvement.' By the end of the first week of December, Ōhata reported that twenty-one shipments were confirmed the week before and an additional ten more shipments were released that week. More shipments were still stuck in customs, but the Chinese government was working with METI to clear them. By late December, shipments had returned to normal levels.

(Smith 2015b, 192) 
On November 24, 2010, China finally started to "resum[e its] rare earth exports to Japan" as the Japanese Ministry of Economy, Trade, and Industry confirmed the anticipated arrival of two shipments by sea (BBC News 2010b). However, even though China resumed exports, it was reported on December 28, 2010, that "China cut its export quotas for rare earths by 35 percent in the first round of permits for 2011, threatening to extend a global shortage of the minerals" (Bloomberg 2010). ${ }^{95}$ The official story behind this move was that the quota for exports had to be reduced "because some of the companies mining the minerals were causing 'severe' environmental damage and had to be closed" (Bloomberg 2010) ${ }^{96}$ In addition to the cut in the export quota, China also announced that it would "raise export taxes for some rare earth elements to 25 percent[,] (...) up from the 15 percent temporary export tax on neodymium” (Bloomberg 2010). ${ }^{97}$

By mid-December 2010, the U.S. was considering filing a complaint against China with the WTO. Japan and the EU were also considering such a move but this did not materialize until prices rose significantly and the situation became more dire:

\footnotetext{
${ }^{95}$ An immediate reaction by the Japanese was to seek diversification of the countries from which it obtained REE, since it realized its over-dependence on China in the embargo. As a consequence, Japan started "negotiating agreements with Vietnam, Mongolia and Australia to develop new mines" (BBC News 2010b).

${ }^{96}$ See Appendix, illustrations $2 \& 3$.

${ }^{97}$ It is important to separate the deliberate and secret order to delay exports of REEs to Japan in customs and the cut in export quotas from the fact that, in 2009, China had already begun to exert governmental influence on the quantity of REEs exploited and on the domestic market, so as to have prices rise-similarly to what OPEC orchestrated in the 1970s. From this intervention in the price mechanism, the customs delays, temporary bans, and reductions of export quotas have to be viewed separately.
} 
In 2010, China's export restrictions of rare earths led Japan to consider similar steps under the WTO, and when export restrictions resulted in a global price increase the following year, Japan initiated consultations with the United States and the European Union, and the three parties filed a WTO complaint in March 2012."

(Smith 2015b, 38)

Finally, on March 14, 2012, U.S. President Barack Obama announced the WTO case against China in cooperation with the EU and Japan. The president justified the complaint against China with classical liberal free trade rhetoric, as follows:

‘(...) American manufacturers need to have access to rare earth materials which China supplies. Now, if China would simply let the market work on its own, we'd have no objections.' Instead, Chinese policies 'currently are preventing that from happening and they go against the very rules that China agreed to follow[.]'

(CNN 2012)

With this March 2012 announcement, the case concerning the Chinese quasi-embargo on REEs entered the WTO's dispute settlement process. ${ }^{98}$ The resolution of this case,

${ }^{98}$ Interestingly, as mentioned above, this case which began in March 2012 was not the first WTO dispute settlement case against China's export practices: "This request for consultations was the first step in the dispute settlement process at the WTO. The request (Dispute Settlement 431, DS431) by the European Union, the United States, and Japan for consultations with China at the WTO on rare earth export restraints was 
including the following appeal by China, would take more than two and a half years. China's defense strategy rested heavily on the argument that the export restrictions were taken to protect the well-being of its population by reducing their production. ${ }^{99}$

However, the effect that China supposedly intended for the quasi-embargo restricting the export of REEs diminished about two years after it was enacted. On October 24, 2012, a Japanese news outlet reported that "China los[t] its rare-earth diplomatic leverage over Japan" (Kyodo 2012). This was largely due to the fact that the Japanese market demand was much below the projected export quota that the Chinese had set at the start of the year, which was about 31,000 tons. ${ }^{100}$ This "suggest[ed that] Beijing may no longer be able to use rare earth minerals as a 'diplomatic card' against Japan in dealing with bilateral issues such as disputes over the Japanese-controlled, China-claimed Senkaku Islands in the East China Sea" (Kyodo 2012).

\footnotetext{
made on March 13, 2012, and came on the heels of a prior dispute settlement panel finding against China on 'measures related to the exportation of various raw materials' (DS394). Although Japan did not participate in this dispute settlement case, the WTO panel found that 'China's export duties were inconsistent with the commitments China had agreed to in its Protocol of Accession. The Panel also found that export quotas imposed by China on some of the raw materials were inconsistent with WTO rules' ('DS394 Summary of Key Findings,' released on July 5, 2011). China applealed this decision the following month, but in January 2012 it lost its appeal on export restrictions on raw materials. Thus, the case on rare earths followed immediately on the heels of the WTO finding against China" (Smith 2015b, 322n36).

${ }^{99}$ See, e.g., Pruzin (2014).

${ }^{100}$ See Kyodo (2012).
} 
As the conflict over the islands exacerbated starting in autumn 2012, this overshadowed the two-year-old REE embargo, as the dispute over the archipelago started to move from the economic and diplomatic realms into that of the military. ${ }^{101}$ The abovementioned realization that in terms of REEs Japan had been overly dependent on China as a supplier certainly helped accelerate Japan's partial ‘emancipation' from China in this area: "Along with efforts to diversify sources of rare earth imports, Japan ha[d] developed alternative materials and advanced recycling technology in a bid to shield itself from China's restriction of rare earth exports" (Kyodo 2012).

Because on February 19, 2014, "the legal right to claim damages [in the fishing boat incident of 2010] would have expired[,]" Japan's "government ha[d] filed a suit with the Naga District Court in Okinawa [against captain Zhan] seeking (...) [\$140,000] to pay for repairs to the damaged Japanese vessels" (Tiezzi 2014d). Naturally, the Chinese Foreign Ministry rejected this move by Japan and backed its citizen and its own claim to the islands in the ECS - not unusual, since China and Japan's foreign relations had experienced an exceptional cooling from autumn 2012 to winter 2014 surrounding the dispute over the Diaoyu/Senkaku Islands following the purchase from private owners of the largest of the islands by the Japanese state:

\footnotetext{
${ }^{101}$ See chapter VI, case one, below; different from the situation in September 2010, “[i]n the wake of Japan's effective nationalization of the Senkakus in September [2012], [the Chinese government did not follow] (...) growing calls in China that Beijing should restrict rare earth exports to Japan. [It] ha[d] continued to export rare earths to Japan" despite the on-going dispute in the East China Sea (Kyodo 2012).
} 
China fired back at Japan in Tuesday's regular Foreign Ministry press conference. Spokesperson Hua Chunying told reporters that the 2010 collision 'was a severe incident when the Japanese side grossly infringed upon China's territorial sovereignty and damaged Chinese fishermen's legitimate rights and interests.' Hua also reiterated Beijing's position that 'any judicial measures adopted by the Japanese side against Chinese fishermen and fishing boats, including detention and investigation are illegal and invalid.'

(Tiezzi 2014d)

The WTO finally ruled on March 26, 2014, "that the Chinese restrictions, which [took] the form of export quotas, export duties and other measures, ran counter to commitments China made when it joined the WTO in 2001" (Pruzin 2014). Even though China tried to utilize its "right to invoke Article XX of GATT 1994" (Pruzin 2014), it had no right to — in the WTO's view— ${ }^{102}$ since there was no

'indicat[ion of a] (...) link between the duties and any environmental or health objective,' [as] the panel declared. 'Furthermore, some of the evidence submitted by the complainants seems to indicate that, contrary to China's assertions, the export duties at issue are designed and structured to

\footnotetext{
${ }^{102} \mathrm{Or}$, at least, in the view of three of the four judges on the panel deciding over China's REE export restrictions.
} 
promote increased domestic production of high value-added downstream products that use the raw materials at issue in this dispute as inputs.'

(Pruzin 2014)

China appealed the WTO decision within the necessary time period. However, with a final WTO decision on August 7, 2014, China lost its appeal and was required - just as in the case on export restrictions on other natural resources decided on a year earlier - that it needed to abide by official regulations and discontinue the export restrictions to accommodate the WTO nondiscrimination rule. Indeed, by September 8, 2014, China's REE exports increased by a margin of 31 percent from the previous month (Xinhua 2014a). Starting January 4, 2015, China officially announced that it had ended the quotas for REEs (Yap 2015).

On April 24, 2015, China decided to discontinue the export tax on REEs hoping the decision would strengthen renewed demand. ${ }^{103}$ Nevertheless, whereas China was producing and offering nearly all REEs on the market in the mid- and late 2000s, now the estimate was that it "produce[d] about 85 percent of global supply" (Stringer 2015). However, given that China had followed a policy of restricting REE exports, it is no surprise that the market share dropped in reaction to Japan and others seeking the necessary resources elsewhere.

${ }^{103}$ See Stringer (2015). 


\section{Localization of the Case in Terms of Honor and Legitimacy}

Even though China enacted export restrictions on certain natural resources in the mid-2000s, tungsten, and molybdenum can be seen as a manifestation of the economic policy of China's overall grand strategy, which pertains to internal legitimacy. They certainly stand out as the most salient case in the analyzed time period in terms of the unambiguous assertiveness China showed on the economic front. For the most part, China kept with its general abiding by capitalism—-perhaps 'with Chinese characteristics'—and continued with "playing our game” (Steinfeld 2010).

Naturally, it seems contradictory at first glance for China to go so hard against (especially) Japan on the economic dimension: Japan has been the number one trade partner of China for decades and it has a big stake in China with a relatively high amount of FDI in China throughout the last three plus decades. In a word, it comes across as irrational for China to do as it did, let alone contradicting its own PD grand strategy. Such sanctioning behavior is usually utilized in situations in which one nation (or a coalition) tries to compel the sanctioned nation to do something, or - at the least - deter it from further escalating the situation. Examples include the sanctions enacted against Iran because of its nuclear program and against Russia because of its assertiveness in eastern Ukraine and the annexation of Crimea.

Relating this assertive behavior to honor and internal legitimacy is not overly difficult since this case involves China's main regional rival, Japan, which some 
may identify as an arch-enemy of China. As mentioned earlier, China's honor was hurt significantly by Japanese militarism and imperialism in the late nineteenth up until the midtwentieth century in the First and Second Sino-Japanese Wars and colonization/quasiannexation of its northeastern territory and eastern seaboard. In today's nationalism within China, Japan still plays an important negative role, especially with respect to overcoming this humiliating trauma. It is not too farfetched to say that much of the nationalist anger associated with this humiliation is directed against Japan and less so against other great powers who were equally involved in this chapter of Chinese history (e.g., Britain, which started it with the First Opium War).

The immediate relationship to the humiliating trauma and China's humiliation of national honor in the past is that the incident which kick-started the REE embargo happened in maritime territory which China considers to be a historically inherent part of its erstwhile imperial empire. Therefore, as China sees it, Japan's control over this part of the ECS is an "ill-gotten [territorial gain]" through unlawful, unfair means (Pillsbury 2015, 205). As mentioned above, the trauma China suffered at the hands of the Western aggressors and Japan triggered a preoccupation with China's sovereignty and especially territorial integrity. On the one hand, China aims to reunify its territory to reach the glory that it once had under the largest territorial expansion during the Qing era. This, for the moment, is restricted to the ECS and SCS, as well as Taiwan, and 'South Tibet' (Arunachal Pradesh). ${ }^{104}$ On the other hand, as China's internal legitimacy is increasingly

\footnotetext{
${ }^{104}$ In the longer term, Chinese territorial expansion could also involve territory in the Russian Far-East bordering Heilongjiang (formerly Manchuria) and Mongolia (Outer Mongolia).
} 
tied to nationalism and ancient culture, and less so to the Marxist-Leninist-Mao-Deng ideological spectrum and economic growth, assertive moves against Japan placate the population and back approval rates for an otherwise not legitimized regime. In relation to nationalism and the Japanese 'Other,' what is also particularly striking is that the incident together with the Chinese assertive economic reaction happened only very shortly before the thirty-eighth anniversary of the official start of Sino-Japanese foreign relations in $1972 . .^{105}$

That China's internal legitimacy still depended on economic growth (i.e., how successful the government was in lifting people out of poverty, creating new jobs, pushing annual growth of gross domestic product (GDP) toward double digits, keeping the market stable) was forgotten for a couple of days by the government. First, the CCP via its Foreign Ministry issued extremely nationalist statements against Japan filled with rage to backtrack to the course of PD:

Because instead of a common identity there are clashing national sensitivities, any inter-state confrontation on any issue that is more than narrowly technical can arouse emotions, generating fears, resentment, or mistrust as the case might be, and necessarily affecting relations with the

\footnotetext{
${ }^{105}$ Equally interesting is the beginning of the Sino-Japanese 'ice age' from 2012 to 2014 . The incident occurred correspondingly just a few days before the scheduled celebration of the fortieth anniversary of SinoJapanese official foreign relations.
} 
state in question across the board. (...) [This kind of] misapplication of norms has occurred as often as there have been confrontations of late, most notably perhaps the September 7, 2010, incident near the Senkaku Islands (Diaoyutai to the Chinese). This was followed by inflammatory Chinese Foreign Ministry declarations that duly produced anti-Japanese agitations, the arrest of some visiting Japanese executives, a de facto embargo on rareearth exports to Japan - and very soon thereafter, by Chinese Foreign Ministry statements that recalled the importance of Chinese-Japanese economic relations, called on the public to stop anti-Japanese demonstrations, and invited the Japanese to continue investing in China.

(Luttwak 2012, 77f)

In summary, the Chinese preoccupation with territorial integrity plus the involvement of Japan as the 'Other' against which most Chinese nationalism is directed made for a situation in which the trauma of national humiliation was triggered and the cultural driver of honor interfered with perhaps otherwise rational behavior and led China off the rational course, off the course of its PD grand strategy, and toward irrational behavior. 


\section{Determining Convergence with or Divergence from PD Grand Strategy}

Having established that it was a case of internal legitimacy in conjunction with the cultural driver of honor which led China to stray from its PD grand strategy course, the specific divergence from (and partial convergence with) PD will be scrutinized further below. See also table 4 for a visualization of this analysis.

Defense of territorial integrity

In China's view, Japan was the first to breach the status quo and arrest a Chinese national in waters which China claims but does not control. The REE quasiembargo was intended as retaliation to a violation of China's (perceived) territorial integrity by Japan. Since the Chinese government does not have to justify its grand strategy to the community of states but rather its own population, it is reasonable to say that this action was beneficial to China's internal legitimacy and its pursuit of national interests, in this case to reunify territories which China considers unlawfully annexed by Japan. That no violent conflict occurred, but merely escalation of words and some assertiveness on the economic front involving the REEs, should also be counted favorably toward peaceful in China's PD grand strategy. 
Increase of national power

On the one hand, if the unilateral export restrictions on REEs and tungsten and molybdenum increased China's overall revenue and profit and at the same time gave it an edge in industrial targeting in support of its own industries, it may be interpreted as a power increase on the dimension of economic capabilities. Also, the world really only realized how powerful China was in terms of access to natural resources such as the REEs in question as the media hyped the situation after the initial export stop, or customs delay, which China imposed. China did flex its (economic) muscles there and the world realized that China had the upper hand when it comes to access to these resources.

Power is often defined as "the ability to get others to act in ways that are contrary to their initial preferences and strategies" (Nye 2011, 11); however, "[e]conomic measures are somewhat more complex. Negative sanctions (taking away economic benefit) are clearly felt as coercive" (Nye 2011,12). China did not regain its maritime territories in the ECS by enacting the temporary export stop (or delay) and four-year plus export restrictions. However, the initial export slowdown may have led to Japan releasing the captain and crew of the trawler which encroached into waters under Japanese control. China got Japan to do something that very likely was not its first preference. So the two rounds of assertive measures, short-term export stop plus mid-term export restrictions, did get Japan to do something it did not initially plan to do and exemplified the power and capability increase China had achieved in the last decades; these measures also illustrated the complex interdependence between a once isolated nation and the developed world with 
which the former could hurt the latter significantly. On the whole, China converged with PD here, too.

Anti-hegemonism

As the export restrictions went mainly against Japan, a U.S. ally, this confirms the factor of anti-hegemonism when looking at it from a global perspective. Also, Japan, along with the U.S. and the EU, was party to the WTO case against China. Seeing this from a West versus East perspective, or a DC versus LDC vantage point, the antihegemonism would have been converged as well. However, China also had a longstanding strategy in which it tried to break the alliance between Japan and the U.S. by attracting Japan and calling on to its Asian nature to illuminate the externality of the U.S. in 'their' region: "Beijing's willingness to extend spats like these to international trade was worrisome. (...) Then for the first time, Japan joined European and American governments in requesting consultations at the WTO with China concerning its restraints of rare earth exports" (Smith 2015b, 201f.). Whereas Japan had not really sided with the West before on such economic issues within the WTO, the export restrictions on REEs had now led it to do exactly that. Thus, in a way, this behavior contradicted the divide et impera strategy of China against the U.S.-Japan alliance. Nevertheless, it was still converging on the whole, as the behavior was directed against the alliance. 


\section{Maintenance of favorable economic markets}

The factor of maintaining favorable economic markets may be debatable as to whether it is actually converging or diverging - especially because this is an outwardlooking factor category in China's PD grand strategy. Rather than either-or, one can argue that it was both converging and diverging at the same time. On the one hand, China may not have suffered under unfavorable conditions, but it was the international market which became more unfavorable concerning REEs and China was diverging from PD, acting assertively, selfishly, and without regard for other nations in the market, which is often referred to as neo-mercantilism. On the other hand, China had the upper hand in the control of REEs, tungsten, and molybdenum, having a quasi-monopoly and, therefore, was able to create a market in which it could profit by driving up the price of REEs through reducing the supply for export, while giving its own domestic market a decisive edge in access to REEs. Thus, China converged here, too. The fact that this played out as described above reinforces the analysis that this is a case of internal legitimacy — China looking out for the benefit of its own population, not that of others, especially DCs.

\section{International responsibility}

China clearly diverged from the PD factor of international responsibility. The export limitations hit the international market hard for the years it was enacted. Objectively speaking, there cannot be much discussion that this was irresponsible behavior on the part of China and nothing where other nations would think they benefitted. Here, 
China diverged from PD. Subjectively speaking, it is possible to ask, as one Chinese scholar once did, "'Responsible to whom? To whose standards? The United States? Never!"' (Shambaugh 2013, 40; partially quoted from Pilling 2010).

Avoidance of 'China threat' misperception

Another outward-looking factor, whether others perceived China as a threat with the export restrictions in 2010 and onwards, is also a rather clear case of divergence. Whereas this was not on a military or violent dimension, it may still have caused a perception in other states that China is looking out for itself more than for the global good; for China to become a global (or regional) hegemon, it would use threats of a coercive hegemon (rather than rewards). Here, too, China diverged from its PD grand strategy.

Increasing China's international reputation

China seems to actually have decreased its international reputation with the assertive nature of the REE export restriction. Since this whole case revolves around internal rather than external legitimacy, this makes sense. Going hand in hand with the two above-mentioned factor divergences, China also diverged from this factor of increasing its international reputation. 


\begin{tabular}{|c|c|}
\hline Factor in PD & Convergence / Divergence \\
\hline Defense of territorial integrity & $\begin{array}{c}\text { Convergence } \\
\text { (in China's view retaliation to a breach by } \\
\text { Japan of China's territorial integrity) }\end{array}$ \\
\hline Increase of national power & $\begin{array}{c}\text { Convergence } \\
\text { (higher prices for REEs exported and } \\
\text { flexing muscles as a show of power to DCs) }\end{array}$ \\
\hline Anti-hegemonism & $\begin{array}{c}\text { Convergence } \\
\text { (action mainly directed against DCs) }\end{array}$ \\
\hline $\begin{array}{c}\text { Maintenance of favorable economic } \\
\text { markets }\end{array}$ & $\begin{array}{l}\text { Convergence \& Divergence } \\
\text { (Int'l market suffered-insofar diverging; } \\
\text { China profited from price hike-converging) }\end{array}$ \\
\hline International responsibility & $\begin{array}{c}\text { Divergence } \\
\text { (irresponsible towards market rules) }\end{array}$ \\
\hline $\begin{array}{l}\text { Avoidance of 'China threat' } \\
\text { misperception }\end{array}$ & $\begin{array}{c}\text { Divergence } \\
\text { (assertiveness albeit non-violence) }\end{array}$ \\
\hline $\begin{array}{l}\text { Improving China's international } \\
\text { reputation }\end{array}$ & $\begin{array}{c}\text { Divergence } \\
\text { (damaging rather than improving reputation) }\end{array}$ \\
\hline
\end{tabular}

Table 4: Divergence from or convergence with PD in the case of the REE export limitations.

\section{Alternative Explanations}

It seems relatively clear that China reacted with an REE quasi-embargo to Japan's arrest of the fishing boat captain and crew in disputed waters of the ECS. Nevertheless, the process of influencing and manipulating the price mechanism by means of restricting exports with quotas which started in 2009 and not in particular with respect to Japan should be separated from the exacerbation that occurred in 2010 and the following 
years. What remains unclear is how intentional this quasi-embargo was on the part of the Chinese and, if it was not intentional that exports were held at customs, then was it the intent of the Chinese government not to intervene in customs officials' independent patriotic acts? Either way, a minimum amount of intent can certainly be assumed. As Smith writes, taking the intentionality argument further in terms of using it as a threat or not in 2010 and onwards:

Whether the Chinese government used this as a threat during the crisis remains suspected but unconfirmed. The difficulty in assessing the exact role of Chinese officials in the embargo of rare earth materials lies partly in the lack of transparency over the export process. If an embargo was imposed, it was informally imposed, and the question remains whether the Beijing officials were aware of the actions taken by customs officials at the point of export.

(Smith 2015b, 201f)

Other than these arguments, there is not much room for alternative explanations. Certainly, that this is a long-term development in China's export strategy concerning REEs has to be mentioned. However, the Chinese government undoubtedly used the crisis with Japan in 2010 to exacerbate the mild trend in export reduction as evidenced since 2006 and-more so-since 2009. Even so, back in 2009, prices of metals - even REEs - had declined in value in response to the 2008 global financial crisis and the toll it took on the global economy resulted in less demand in raw materials. 
Reducing its exports merely meant adjusting to this situation to not lose too much on the lower prices which resulted from lower demand. By 2010 and onwards, the global economy had picked up momentum, and-if the initial export reduction was in reaction to a weak global economy - then reducing it further would not have made sense. In essence, this particular case is unambiguously an assertive strategic act using economic means by China against Japan.

\section{Conclusion of Case Analysis}

In almost every respect, this case catered to China's internal legitimacy. No nation could have approved of what China did with its market might in the area of REEs given its assertive and unilateral manner. Its own population, and especially the hypernationalists among them, surely was pleased when China stood up against the ex-colonial lord and showed Japan (and the West) its growing strength:

To demonize Japan, China has sent the message that it regards Japan's wealth, and its position as America's ally in Asia, as products of ill-gotten gains from World War II. Professor Arne Westad (...) calls this phenomenon a 'virulent new form of state-sanctioned anti-Japanese nationalism.

(Pillsbury 2015, 205) 
The cultural driver of honor was important here because China attempted to correct and avenge its erstwhile violation of national prestige and reputation—as per the so-called one hundred years of national humiliation complex - in a way that was still short of actual violent warfare. However, this sort of assertive behavior on China's part led to excessive violence on the streets of Japan and China against the respective national citizens or businesses in each territory.

Also, acting assertively against others is what the hyper-nationalist factions of China's population often demand from their government. Such demands are often expressed in Internet blogs and forums, as well as in anonymous letters to the Foreign Ministry. For example, one such letter contained calcium pills to suggest that the government needed to develop 'backbone' against the international community and show the country's military might. Thus, these export restrictions mostly catered to internal legitimacy and mostly diverged from China's PD grand strategy, especially on the outwardlooking factors which relate to external legitimacy. 


\section{The Establishment of the Asian Infrastructure Investment Bank}

\section{Introduction of the Case}

Since 2013, China had been proposing to set up a new international development bank called the AIIB to help with economic development, especially in neighboring Asian less developed countries (LDCs). The proposal was well received by most Asian states but regarded skeptically by allies of the United States and the West in general. This is because China did not make its intention clear in founding such a new financial institution since the IMF, WB, and the Asian Development Bank (ADB) already handled loans for LDCs and infrastructure development support. The AIIB was founded on October 24, 2014, with more than a dozen Asian and non-Asian countries as founding member signatories, including Vietnam, India, and the Philippines. Thus, while it is a valid argument that this case is an example of assertiveness, the presence of countries that are not really allies of China but rather have more or less long-standing and unresolved disputes with China should hint that this initially was not a geo-economic or geo-political instrument of China.

Nevertheless, the ambiguity of this case makes it interesting. At first look, this is a case that perfectly converges with the PD grand strategy. On the dimension of legitimacy, it can be seen as pertaining to both internal and external, although external 
legitimacy is likely more at the heart of this action (i.e., to give China recognition and enhanced reputation from the global state community).

\section{Detailed Course of Events of the Case}

Shortly after the 2008 global financial crisis, China became more assertive in pushing for changes in the organizational setup concerning economic international organizations and their underlying ideology. The Washington Consensus had informed the IMF and WB since the Orthodox Revival under Margaret Thatcher and Ronald Reaganattaching strings of privatization, deregulation, free trade promotion, and democratization to loans given out by these organizations.

In March 2009, China's central bank governor, Zhou Xiaochuan, announced that it might be time to move away from the dollar as the world's global currency and develop a super-sovereign currency. Later that month, Chinese President Hu Jintao at the G20 Summit similarly called for an overhaul of the global financial system. Since then, the Chinese have continued to put forward the notion that the U.S. dollar should no longer serve as the world's reserve currency, and have increasingly pushed for reform of the International Monetary Fund to reflect the voice of China as well as other developing countries. Yet beyond calling for change to the 
current system, it is unclear what level of responsibility China envisions for managing the new system.

(Economy 2012)

This was also reflected in the speculated push for a non-European successor of Dominique Strauss-Kahn, who resigned in May 2011 from the IMF managing directorship. As we know now, it took a lot of convincing for Christine Lagarde to become the new IMF managing director. Likely, this took a promise for the RMB to become one of the Special Drawing Rights (SDRs) basket currencies - even if it was not going to fulfill all of the conditions on the list, given the speculated artificial undervaluation of the RMB to keep exports attractive. However, at this point and with the looming leadership change within the CCP from Hu Jintao to Xi Jinping, it may have become clear that the IMF and other existing international organizations would not change their outlook and conducting business in relation to China-possibly prompting the development of new organizations by China itself.

Before introduction of the AIIB idea by President Xi, "[i]n 2014, BRICS economies formed a development bank of their own, but it remains to be seen if this bank will pose any significant challenge to existing institutions or even if its members will be able to sustain the internal consensus necessary to make the bank effective" (Christensen 2015, 57). Whereas BRICS's New Development Bank (NDB) did not seek membership from a large number of nations, this was different with the AIIB. All the developments prior to the AIIB proposal and founding showcase China's "interest in developing 
alternative economic and financial institutions to traditional Western-backed regimes. One example is China's plans for an Asian Infrastructure Investment Bank (Yazhou jichusheshi touzi yinhang 亚洲基础设施投资银行)”(Lanteigne 2016, 63).

During a visit to Indonesia in October 2013, President Xi first mentioned the idea of a new Asian bank which would work along the lines of the so-called 'Beijing Consensus'-giving loans without conditions attached. The still-to-be-named new financial institution

was to have an initial value of US\$50 billion with Beijing providing the greatest proportion of the initial start-up funding. The initiative was in part a response to Chinese frustration over what it considered the slow pace of infrastructure development in Asia and the domination of Western interests within the IMF and World Bank, despite China's rise as an economic power.

(Lanteigne 2016, 64)

$\mathrm{Xi}$ foresaw the AIIB "as an institution that will finance infrastructure construction and promote regional connections and economic integration in his speech at the Indonesian House of Representatives in Jakarta" (Xinhua 2015o). However, the ADB, as well as the IMF and WB already functioned to provide this sort of financing. Because those institutions are dominated by Japan, the U.S., and Europe, they did not fit any longer with the Chinese approach, prompting the proposal from Xi. Also, given the track record of the Beijing Consensus, as David Shambaugh writes, "Beijing's 'offend no one' and 'attach no 
strings' approach has worked well” $(2013,107)$. Even so, Shambaugh also cautions that "China has received considerable international criticism for its lack of transparency and 'no strings attached' policies, in many ways the aid programs are an untold success story" (2013, 202). Indeed, the AIIB promises to become a great success in that regard.

A little more than a year after its first mention, in October 2014, "[t]wentyone Asian countries ink[ed] a memorandum of understanding (MoU) in Beijing on establishing the AIIB" (Xinhua 2015o). ${ }^{106}$ "President Xi noted that, "to build fortune, roads should be built first[,'] an idea in keeping with an 'Asia-Pacific Dream' of regional economic development" (Lanteigne 2016, 66). Not surprisingly, the signatories were exclusively Asian nations, if one counts Kuwait and Oman as 'West Asian.' In that sense, the AIIB stayed true to its name as being by and for Asian nations. Still, the Chinese leadership of the bank seems to have wanted to drag out the founding process, so that a coming pro-AIIB dynamic would convince other nations, especially Asian nations but possibly also supra-regional support from non-Asian nations, to join as founding members, with a deadline set for March 31, 2015. Most of the twenty-one signatories maintained friendly relations with China with only the Philippines, India, and Vietnam being relative surprises - although India is a member of the BRICS and the NDB.

\footnotetext{
${ }^{106}$ Signatory countries to the MoU were Bangladesh, Brunei, Cambodia, China, India, Kazakhstan, Kuwait, Laos, Malaysia, Mongolia, Myanmar, Nepal, Oman, Pakistan, the Philippines, Qatar, Singapore, Sri Lanka, Thailand, Uzbekistan, and Vietnam. See Xinhua (2015o).
} 
While it was certainly a small setback to not have Indonesia join in October, since Xi had first announced the idea of the AIIB there, "Indonesian Finance Minister Bambang Brodjonegoro sign[ed] an MoU to join the AIIB as a prospective founding member" (Xinhua 2015o) in late November 2013. "The Memorandum of Understanding [MoU] on Establishing the AIIB specified that its authorized capital is $\$ 100$ billion and the initial capital will be around $\$ 50$ billion. The paid-in ratio will be 20 percent" (Xinhua 2015o).

Shortly thereafter, "New Zealand, the Maldives, Saudi Arabia and Tajikistan officially join[ed]" (Xinhua 2015o). New Zealand's joining marked a definite first crossing of a geographic, ideological, and civilizational border with an Oceanic, exBritish Crown colony, and Judeo-Christian state, respectively, joining the AIIB endeavor in January 2015. In the background, the media had begun to brand the AIIB as a challenge to the U.S., as the U.S. was not joining and apparently trying to strong-arm its Asian allies to stay away from the AIIB as symbolic founding members, especially its closest allies (i.e., Australia, Japan, Taiwan, the ROK) after the befriended Kiwis already sheered out. Naturally, the Chinese tried to convince them of the opposite:

Shortly after the inception of the AIIB, the United States expressed its misgivings about the new bank due to concerns about Beijing's growing diplomatic power as well as whether the bank would uphold 'international standards of governance and transparency'. Washington also appeared to be tacitly discouraging its partners and allies from signing on to the AIIB. The 
original signatories to the AIIB project were governments from East, South and Southeast Asia, although New Zealand, which has a long history of independent foreign policymaking vis-à-vis the United States, did agree to sign on. Other American partners in the Asia-Pacific region such as the Philippines and Singapore also agreed to join, but others such as Australia, Japan and South Korea originally opted to steer clear, mainly due to US concerns. Despite Beijing's call for AIIB partners from all around the world, during the opening months of 2015 it appeared that the new bank would be strictly regional in scope.

(Lanteigne 2016, 65f)

In line with New Zealand joining, March 2015 saw Chinese lobbying efforts pay off and those of the U.S. fail with a domino effect of Western nations joining as prospective founding members. The U.K.'s application to join on March 12 was certainly the trigger of this domino effect (Xinhua 2015o) — given its status as the financial capital of Europe. What followed was

an unusually sharp rebuke by Washington, especially in light of the 'special relationship' between Britain and the United States, the UK government was accused of making the decision without consulting its American partner. As one US official noted, 'We are wary about a trend toward constant accommodation of China, which is not the best way to engage a rising power.' London counter-argued that British economic interests would be 
well served by AIIB membership and greater financial cooperation with Beijing.

(Lanteigne 2016, 65)

The other European heavyweights, Germany, Italy, and France, followed suit within a week of Britain's application. Luxemburg and Switzerland also applied shortly thereafter (Xinhua 2015o).

Following the often feared challenge to the existing international organizational setup, Chinese PM "Li Keqiang stresse[d at a meeting with ADB President Takehiko Nakao in late March] that the AIIB will cooperate with and be complementary to existing financial institutions[, and that t]he AIIB will take an open and inclusive attitude" (Xinhua 2015o). Similarly, President Xi successfully beat the big drum in an effort to ameliorate fears of (above all) American allies thinking that the AIIB is a manifestation of China becoming a present or future threat to the U.S.-led liberal world order or China's neighbors fearing Beijing's further influence. Just a few days before the deadline, Xi promised at the BFA annual conference that China

will vigorously promote a system of regional financial cooperation, explore a platform for exchanges and cooperation among Asian financial institutions, and advance complementary and coordinated development between the AIIB and such multilateral financial institutions as the Asian Development Bank and the World Bank. (...) The 'Belt and Road' and the 
AIIB are both open initiatives. We welcome all countries along the routes and in Asia, as well as our friends and partners around the world, to take an active part in these endeavors.

(Xinhua 2015o)

Before the March 31 deadline, applications to join from Australia, the ROK, and the ROC marked a lost fight for the U.S.- - with only Japan and the U.S. not having joined. The defection of the former three was more than unexpected. After this sort of traction caused by the European heavyweights in mid-March, Iran, the United Arab Emirates (UAE), Turkey, Egypt, Georgia, Brazil, Russia, Kyrgyzstan, Israel, South Africa, Azerbaijan, Iceland, Portugal, Poland, Austria, the Netherlands, Spain, Malta, Denmark, Finland, Sweden, and Norway jumped on the train more or less last minute. ${ }^{107}$ The former eleven countries cannot have been big surprises since, either ideologically or geographically, these nations seem like ideal candidates. However, the latter eleven European nations constituted further surprises and losses for the U.S. effort to not embolden the AIIB endeavor.

The day after the deadline, the Chinese Ministry of Finance announced that "Germany becomes the first prospective founding member of the AIIB" (Xinhua 2015o) certainly an announcement meant to catch the attention of the media. Until April 15, the

\footnotetext{
${ }^{107}$ See Appendix, illustration 4.
} 
number of prospective founding members inflated to 57 globally, up from the original 21 signatory countries which were mostly Asian. As mentioned above,

Taiwan applied to join, potentially under a different name such as 'Chinese Taipei' to avoid enflaming the 'one China' question. However, in April 2015 it was announced that Taiwan would not be able to apply as a founding AIIB member due to a disagreement over a proper name. Of all the applications to the AIIB, only one state was rejected outright by Beijing for having insufficient credentials: North Korea.

(Lanteigne 2016, 66)

Within two months' time, after negotiations of all accepted as founding members, the governing framework (Articles of Agreement) was finalized on May 22 and subsequently signed on June 29, 2015, in Beijing, which was set to be the AIIB headquarters. After ratification of the framework by a sufficient number of founding and common members (i.e., those that applied after the deadline of March 31), "[t]he AIIB is formally established in Beijing after its Articles of Agreement come into effect" (Xinhua 2015o). 


\section{Localization of the Case in Terms of Honor and Legitimacy}

Much like the tributary system has been an institutionalization of China's status, contributing to its prestige, reputation, and recognition, the AIIB should be similarly considered. Also, much like the tributary system contributed to its internal and external legitimacy in history, the AIIB can do something of that sort-at least for external legitimacy purposes.

China's heavy investment in neighboring countries with no strings attached has been taking place more and more in recent years - and such investment is not just limited to its neighborhood but is also prevalent in resource-rich African countries, for example. While it may have significantly increased China's external legitimacy by adding to its reputation, this is mainly true when it comes to the governments of positively affected recipient countries. On a more negative note, it also has raised eyebrows with local populations: China tends to bring its own workers from China and often the heavy investments may only benefit the recipient countries in the long term, while short-term job creation and the like is not part of the equation in China's investment. Thus, the outside spectator can get the impression that China's altruistic-seeming investments in its neighbors' or trading partners' infrastructure are merely out of self-interest to obtain easier access to resources and trade or they may be earmarked for future access of its own military in the case of airports and seaports. 


\title{
Determining Convergence with or Divergence from the PD Grand Strategy
}

\author{
Defense of territorial integrity
}

If the AIIB is to have anything beyond purely economic calculations, it can be conceived of as an increase of security for China's territory-depending on the infrastructural projects that are funded in the future:

China's foreign policy concepts toward its weak neighbouring states, such as the 'One Belt, One Road' strategy, are premised on the assumption that economic exchange and a commitment to common development are the most effective means of ensuring stability on its borders.

(Taylor and Francis 2015)

The logic behind this is likely that investments in the infrastructure of China's neighbors will not come back to China only as stimulus for its home economy by having used Chinese construction companies for the project and being able to export more to a country which is becoming an emerging market. Also, these investments promise to make the countries along China's periphery more stable and safer and, therefore, make China safer as well. In addition, should military conflict loom in China's periphery and should China get involved, it would probably be easier for the People's Liberation Army (PLA) to bring equipment and personnel to where it is needed through the facilitative function of good infrastructure. 
Quite generally, that China is leading the way to distribute money where it is most needed for development purposes also increases the likelihood of its neighboring states becoming less threatened by China's rise and more friendly toward China, if they accepted the development assistance from the AIIB. Therefore, the AIIB also contributes to China's border security and its defense of territorial integrity. Insofar, China converged with PD grand strategy regarding this factor (see table 5 for a summary of convergences and divergences).

Increase of national power

Since the AIIB is headquartered in Beijing, and since this institutional construct is one out of the Chinese feather, this is clearly an increase in power. From being headquartered in China alone, it is possible to assume that the Chinese government will have privileged access to decision-making within the AIIB. Also, the person heading the new bank will be from China and likely all who succeed him in the future-as with the tradition of a European heading the IMF and an American heading the WB.

Naturally, China, which provided the main impetus and idea for the bank, will also provide most of its funding; these large investment sums from the AIIB can act as rewards and threats at the same time for the recipient nations in China's Asian periphery. As rewards can be taken away, there is an implicit threat involved even in these seemingly altruistic economic development actions. Given that China also provides much of the funding, it is not too farfetched to assume that this will also give it considerable power over 
agenda-setting, for example. Last but not least, having this new institutional vehicle will spread the Chinese idea of 'no strings attached' development funding along the lines of the (in)famous Beijing Consensus. Power balancing behavior may very well be underlying these actions in that a power increase exists - if not at present, then more likely than not in the future through having institutionalized China's international policy preferences in the AIIB and, therefore, it will likely live on even separated from China's economic success or failure.

Anti-hegemonism

If one subscribes to the view that founding the AIIB is an inherently assertive move meant to ring in a new era in global governance and eventually succeed the $\mathrm{ADB}$ and set a precedent for a possible future global institution to replace the IMF and WB, then this would mean convergence with PD grand strategy. Also, the U.S. superpower and its arch-enemy and very close U.S. ally, Japan, have not joined as founding members of the bank although some U.S. allies did - another indicator of fulfilling anti-hegemonism via a strategy of divide et impera-separate and rule. Whether or not this leads to a restructuring of global governance economically, it remains to be seen whether the AIIB and other such "organizations prove effective[.] (...) [E]ven if China plays a large role within them, as will surely be the case, they might simply supplement rather than undercut the existing institutions in which China and the United States both play a role" (Christensen 2015, 57). 
The AIIB can also be seen as divergence from this factor in the PD grand strategy: Founding institutions after its own image and in ways that will indisputably bring about memories of medieval times in which China had considerable influence via its tributary system may very well be counted as seeking hegemony. Thus, if China does in fact have hegemonic ambitions, especially in Asia, then that may be counted as an action against its own principle of anti-hegemonism. Also, some Western nations and U.S. allies in Asia joined the AIIB, which would equally contribute to the founding of the bank being seen as diverging from PD grand strategy; if it was directed against the current hegemon, it should not have accepted the inclusion of Western powers, such as Germany and Britain, or the ROK—all of which are close allies of the U.S.

Maintenance of favorable economic markets

Increasing the economies of adjacent nations in Asia with development assistance will likely help China's own export economy, as its industries and population will demonstrate higher demand for Chinese products the more the economy grows. As Jeffrey Smith writes:

The AIIB will grant China a virtuous cycle of benefits, expanding its political and economic leverage across Asia and aiding its efforts to elevate the yuan as an international reserve currency. And it is China's own companies, with unrivaled experience building affordable infrastructure, 
that will be uniquely positioned to reap the benefits of the AIIB's initial capitalization of $\$ 100$ billion.

(Smith 2015a)

Also, if China invests in these nations' infrastructure the way it does in Africa (i.e., employing its own workers, which it brings to the construction sites, with its own statedirected corporations), then it directly fuels China's own economy via extra turnover for corporations and remittances sent back to China by workers. Also, what concerns the AIIB likely being an amplifier of China's 'Beijing Consensus' is whether this institution will also lead to more favorable international markets - at least for the Chinese economic conduct. Therefore, without much doubt, this converges with PD grand strategy.

\section{International responsibility}

When it comes to determining whether the AIIB will be perceived by the international society of states as an institution founded by a responsible stakeholder in the international system or by an ambitious, exploitative, and selfish future global hegemon remains to be seen and will depend on the viewpoint of those who evaluate it; as David Shambaugh writes:

[T]he West's call for China to play a greater role in global governance is (...) 'a trap to exhaust our limited resources!' (...) Not only do many see global governance as a trap for China, they also question the concept of 
'responsible power.' 'Responsible to whom? To whose standards? The United States? Never!' shouted one scholar.

(Shambaugh 2013, 40; partially quoted from Pilling 2010)

On the whole, it seems clear at first look that the AIIB is meant to help Asian neighboring nations which are LDCs. Thus, establishing this institution which will make it easier, quicker, and more efficient for these nations to obtain infrastructure investment should elevate approval rates among these neighbors, especially those that remain suspicious of whether China is a threat or not. Since this bank is for Asia specifically, whether these nations perceive this as responsible behavior or not should matter most.

Nevertheless, the last two centuries were mostly dominated by Western nations, also considering that the last two global hegemons were the British and, currently, the Americans. The global governance we see today is still largely influenced by the West. The U.S. and Japan seem to have perceived the AIIB founding as an attempt by China to go against institutional economic practices as the U.S. and the West would prefer themalong the lines of the orthodox-liberal Washington Consensus. Thus, the U.S. has pressured its Asian allies and tried to persuade nations in the Indo-Pacific region not to join as founding members of the AIIB. This clearly constitutes a perception by the U.S. and Japan of China acting irresponsibly. However, this is a very large minority because even close U.S. allies such as the ROK and Australia in Asia-Pacific joined the AIIB founding efforts of China. Also, the cherry on top was really the ascendance of non-Asian DCs such as Germany or Britain which ultimately demonstrates international approval and makes the 
U.S. and Japan's minority position appear inconsequential. Additionally, in early December, the IMF decided to include the Chinese RMB as basket currency together with the U.S. dollar, euro, British pound sterling, and Japanese yen—which can indirectly be counted as the IMF's approval of a more active China. ${ }^{108}$

Avoidance of 'China threat' misperception

Conceivably, creation of the AIIB may have been meant to do just that (i.e., avoid others interpreting China's rise as threatening). Rather, the payoff via infrastructure investment in China's periphery could likely change some decision-makers' minds to accept China's preponderance in the long term - up to it being the global hegemon much like in hegemonic stability theory (HST)—so as to put them in a position to believe that following China's lead will benefit them in one way or another. Thus, the AIIB and associated perceptions by future investment recipients would constitute converging to PD grand strategy.

However, the AIIB may have had just the opposite effect: China reaching out regionally to gain more influence economically in Asian neighboring states may reinforce fears that China - with rising power-also exhibits rising regional hegemonic ambitions. The AIIB could be meant to cement this sphere of influence in economic and

\footnotetext{
${ }^{108}$ See IMF (2015). This decision is another example of symbolism in international affairs, as the Chinese government has actually not fulfilled all conditions for the Renminbi to be warranted inclusion as basket currency for SDR.
} 
financial terms for decades and centuries to come - much like the tributary system did in the medieval past. Arguing along these lines-really depending on one's viewpoint and, possibly, future trajectory of the institution, the founding of the AIIB would diverge from PD grand strategy as an assertive action.

Increasing China's international reputation

"Some applaud China for assuming greater international responsibility and wielding soft power to aid Asia's growth. Some oppose the move as undermining the U.S.led economic order and using aid as a tool to advance China's strategic agenda" (Smith 2015a). Whether the endeavor to initiate the AIIB is with benign, altruistic intentions or selfish, power-maximizing ambitions, the goal of this institution (i.e., development of Asia) is a noble cause in itself - probably to be seen separately from China's intentions. Spending large sums of money to the apparent advantage of adjacent nations - some of which cannot look back on historically friendly relations with the Middle Kingdom — surely increased China's reputation now and for the future. This perfectly converges with PD grand strategy. 


\begin{tabular}{|c|c|}
\hline Factor in PD & Convergence / Divergence \\
\hline Defense of territorial integrity & $\begin{array}{c}\text { Convergence } \\
\text { (by way of stabilizing periphery, AIIB may } \\
\text { increase security for China's territory) }\end{array}$ \\
\hline Increase of national power & $\begin{array}{l}\text { Convergence } \\
\text { (AIIB headquartered in Beijing; large } \\
\text { investment sums can act as rewards and threats } \\
\text { at the same time via threats to take them away) }\end{array}$ \\
\hline Anti-hegemonism & $\begin{array}{c}\text { Convergence \& Divergence } \\
\text { (convergence: U.S. superpower did not join but } \\
\text { some U.S. allies did-divide et impera; } \\
\text { divergence: own hegemonic ambitions/other } \\
\text { DCs and U.S. allies joined) }\end{array}$ \\
\hline $\begin{array}{l}\text { Maintenance of favorable } \\
\text { economic markets }\end{array}$ & $\begin{array}{l}\text { Convergence } \\
\text { (increasing the economies of adjacent nations } \\
\text { plus directly fueling its own economy, too) }\end{array}$ \\
\hline International responsibility & $\begin{array}{c}\text { Convergence } \\
\text { (meant to help Asian LDCs; ascendance of non- } \\
\text { Asian DCs shows international approval) }\end{array}$ \\
\hline $\begin{array}{l}\text { Avoidance of 'China threat' } \\
\text { misperception }\end{array}$ & $\begin{array}{l}\text { Convergence \& Divergence } \\
\text { (convergence: AIIB meant to do just that; } \\
\text { divergence: perceived hegemonic ambitions) }\end{array}$ \\
\hline $\begin{array}{l}\text { Improving China's international } \\
\text { reputation }\end{array}$ & $\begin{array}{c}\text { Convergence } \\
\text { (improved China's reputation because of } \\
\text { seemingly altruistic spending) }\end{array}$ \\
\hline
\end{tabular}

Table 5: Divergence from or convergence with PD in the case of the AIIB.

\section{Alternative Explanations}

As mentioned above, some observers interpret the AIIB as a power political instrument of China to show discontent with U.S.-led Bretton Woods institutions like the IMF and $\mathrm{WB}$, along with the ADB. In such view, economic calculation may not play a big 
role but rather China's pursuit to replace the institutions of the current global order in the long term does. This is an alternative view that has the very big picture in mind and is very long term. The premium here is placed on fear and this would be an explanation in terms of pure power politics. A more geopolitical take would be to see the AIIB as a tool to cement a Chinese sphere of influence and China's regional primacy in Asia. This is similar to the above alternative explanation but with a short- to mid-term viewpoint and concerns a more regional than global level of analysis.

An alternative explanation based more on values than power politics is one hypothesizing that China wants to promote its own Beijing Consensus versus the Washington Consensus. It certainly is similar to the power political explanation but has to do with changing values on the global level in the long term.

Economic interest may also have played into the decision to propose and found the AIIB. On the one hand, having a better regional economic environment benefits China because its economy still depends heavily on exports. Adjacent nations with economies that are doing better will ask for more goods to be imported from China. On the other hand, the AIIB may turn out to be an economic stimulus program for the Chinese economy more directly: If China operates its investment in the infrastructure of Asian LDCs much like it does in Africa, then bringing Chinese laborers to foreign construction sites and having Chinese (state-owned or private) corporations carry out the infrastructure construction will funnel the 'investment' partly back to China directly, not just indirectly 
through higher export revenues which may or may not happen based on the respective LDC's future trajectory.

[T]he West's call for China to play a greater role in global governance is (...) 'a trap to exhaust our limited resources!' (...) Not only do many see global governance as a trap for China, they also question the concept of 'responsible power.' 'Responsible to whom? To whose standards? The United States? Never!' shouted one scholar.

(Shambaugh 2013, 40; partially quoted from Pilling 2010)

David Shambaugh also insinuates an argument of exploitative behavior which could be advanced and facilitated by the AIIB in the future:

Much of China's aid comes in the form of hard infrastructure: roads, rails, buildings, stadiums, etc. Even though these do have a positive impact on the recipient country in the end, they are normally built entirely with imported Chinese labor by Chinese construction companies with contracts from the Chinese government. This combined with an excessive and obsessive focus on extractive industries and raw materials has led to charges of 'neo-colonialism' (which Beijing is hypersensitive and defensive about).

(Shambaugh 2013, 110) 
If that were true, the AIIB is an important springboard for China to further legitimize its presence in LDCs with an altruistic façade of helping them with economic developmentnow also in the name of the many holier-than-thou European nations which joined as founding members and are most often associated with international ethics, while China is carrying out an ulterior motive of realizing its own national interest.

\section{Conclusion of Case Analysis}

Very similar to the OBOR, the AIIB proposal and founding perfectly converged with the PD grand strategy. The little doubt there is about possible divergence from PD grand strategy is the interpretation of China's ambition in Asia as a regional hegemon, on the global level of challenging the organizational structure which the U.S. created with its allies after World War II and the Cold War, and the perception of many Asian nations that China may be a possible future threat. All these ambitions cannot be argued against as they either remain to be seen or are already implicitly ingrained in such grand strategy manifestations as the AIIB; sometimes China follows more than one motive at a time, much like a mixed-motive interpretation of U.S. hegemony - using rewards and threats.

That the AIIB was intended mostly for external legitimacy purposes becomes clear immediately given the front-and-center LDC development endeavor for 
which the AIIB was created. However, the external legitimacy has come and will come from multiple corners. First, it comes from LDCs profiting from infrastructural development financing and China being celebrated as a 'responsible great power' in the meantime. Second, it comes from China's profiting financially itself since the loans will be given out in RMB. Third, it comes from many U.S. allies having joined as founding members while the U.S. and Japan did not join and basically lost this stand-off. Fourth, it comes from further establishing the Beijing Consensus internationally and using the AIIB as a precedent for future world order once the U.S. relinquishes leadership fully. Finally, it comes from living up to the earlier success of China's medieval tributary system.

The double-effect that the OBOR had is equally relevant for the AIIB with respect to serving external legitimacy at the same time as internal legitimacy: First, China's economy will be served by the AIIB despite the initial investment of billions into it since construction companies likely will be coming from China—even in a fair public bidding process because few can do work cheaper than China with Chinese labor. Also, in the long term, profits will derive from being able to export more to affected LDCs and gaining access to natural resources there. Thus, the AIIB will help the economy to be stimulated and earn back the initial investment into it. This is relevant since economic growth still figures into internal legitimacy, even though nationalism and historic legacy are quickly becoming important parts of it.

As for the historic legacy for internal legitimacy, the humiliation complex is accommodated by the U.S. and Japan both staying out of the founding of the AIIB and- 
so far-also out of common membership. Actually, the AIIB is often interpreted as a challenge to the U.S. and the Japan-led ADB. Standing up to China's arch enemies brings the CCP extra points for the AIIB project, especially with hyper-nationalists.

External legitimacy, nevertheless, is the key component here in terms of honor and legitimacy. What concerns this interplay of external and internal legitimacybeing a benign and altruistic leader in the regional Asian and global community while at the same time trying to serve China's own national interest-, in essence, is that "[t]he AIIB has the virtue of advancing both agendas, but it represents just one finger in a Chinese hand grasping Asia in an ever-tighter embrace” (Smith 2015a).

To come back to external legitimacy, the 'win' against the U.S. involved the joining of very close American allies since the U.S. did not condone such actions. The reason for the Europeans and traditional U.S. allies joining the AIIB seems like a Chinese success of offers for buy-off and a superficial benign hegemonic strategy having worked out. Publicly, however, the Europeans claimed that their motivation for joining was to influence the initial setup of the AIIB and its governing framework so as to hold China to its word of being complementary to the IMF, WB, ADB, and other pre-existing international organizations. On the Chinese side, the joining of many U.S. allies without Japan or the U.S. was certainly one side of the success in the AIIB story: This was a firsthand, publicly played-out show of risen status of the PRC next to a declining U.S. hegemon which could not enforce alliance discipline and "soundly appeared to [have lost]" 
(Lanteigne 2016, 66) to the lure of the hard power of Chinese money packaged into a 'good cause' (i.e., helping develop infrastructure of needy states).

In the long term, the RMB as currency in which the AIIB loans are given out, will gain importance internationally. The imminent finalization of the founding of the AIIB in late December 2015 put additional pressure on the IMF—-besides the size of the Chinese market and growth of Chinese power over the last decades- to accept the RMB as an SDR basket currency earlier that same month. The trajectory seems to be that the RMB will first follow in the footsteps of the euro as the second most dealt currency in the coming decades before it takes over the U.S. dollar.

Last but not least, the leadership showcased by China in suggesting the AIIB and realizing it in such a quick process while gaining the membership of a range of global nations, including European nations, is an immense upgrade to its status, tackles the humiliation complex, and brings the Chinese back on track to pick up from pre-1839 by setting up a sort of modern tributary relationship for the twenty-first century. 


\section{WITHIN-CASE STUDY GROUP THREE: MILITARY STRATEGY}

[In the state of Chu there lived a man] who [was] vaunting his wares, saying: 'My shields are so strong that nothing can penetrate it.' Then he vaunted his spears and said: 'My spears are so sharp that they can penetrate anything.' Someone said: 'What if we used one of your spears against one of your shields?' To which there was no reply, because a shield that is impenetrable and a spear that is invincible cannot co-exist in the same universe.' 109

(Eoyang 2006; translated from Han Feizi)

\section{Case Selection and Classification}

China's declaration of an ADIZ over the ECS in late 2013 and its continued participation in UN PKMs during the analysis time frame stand as prime examples of confirming to the legitimacy conditions posed to case selection. The ADIZ over the ECS is clearly related to internal legitimacy, as it challenges Japan's (and Taiwan's) claim to the Senkaku/Diaoyu islands and surrounding waters and, therefore, potentially also the

\footnotetext{
${ }^{109}$ The original Chinese from Han Feizi, chapter 36 (難一), no. 4, is: 楚人有槅楯與矛者, 譽之曰: 「吾 盾之堅, 莫能陷也。」又譽其矛曰:「吾矛之利, 於物無不陷也。或曰: 『以子之矛陷子之楯, 何 如? 」其人弗能應也。夫不可陷之楯與無不陷之矛, 不可同世而立。This story from Han Feizi has become an idiom in Chinese language of expressing that something is self-contradictory.
} 
alliance led by the U.S. When speaking about military strategy in the grand strategy design, it is a bit harder to find an example that pertains to external legitimacy in China's case, as a great many actions by China and its PLA were perceived to be actions that speak to internal legitimacy with which China wanted to show strength and opposition to other powers, especially Japan, the U.S., and India. Thus, China's continued participation in UN peacekeeping missions can stand as a relatively unblemished example of military strategy pertaining to external legitimacy.

Other examples of external legitimacy are not very plentiful in the time frame chosen here: "When one examines a number of other recent international challenges or crises - Sudan, Iran, Iraq, Syria, Libya, Afghanistan, Somalia — an aloof and unhelpful China is $(\ldots)$ evident. On such issues that concern the international community and require multilateral action, China prefers to remain on the sidelines" (Shambaugh 2013, 46). Thus, examples that live up to the quality of UN peacekeeping participation are hard to come by.

First, the only other external legitimacy example may be a non-event case study of China not having engaged in any aggressive war actions, or war at all, in the last several years. China has contributed to relative systemic peace in these years albeit growing more powerful at the same time. However, this was also secondary in terms of salience during this time frame and cannot be said to have enhanced China's external legitimacy.

Second, China's military modernization efforts and military build-up during 2009 to 2015 were significant. The part of China's gross domestic product (GDP) used for 
military budget increased continuously in these years. Also, China's first aircraft carrier, the Liaoning, which was built during the late Soviet era in the 1980s, made its maiden appearance in September 2012 in the service of the PLA Navy. Gaining more military power capabilities is certainly an inherent part of China's grand strategy, and so it belongs to the more salient examples, too.

Third, China's advances in asymmetric military capabilities and operations are also salient examples of internal legitimacy-related aspects of military strategy. Very much in the news were China's cyberattack units, which supposedly operated out of a Shanghai skyscraper and kept other great powers busy. Many experts have named China's cyberattack operations as top of the line globally. Also, China has made extraordinary advances in its air space program and still is leading in its ballistic missile programs, thereby enhancing its asymmetric power capabilities-looking to the U.S. at eye level or above in some areas.

Fourth, China's efforts to gain access to foreign ports in Pakistan, Sri Lanka, Bangladesh, Myanmar, and other countries (often dubbed the String of Pearls) can also be seen as an example relating to internal legitimacy. Naturally, China would not publicly stress that they may plan to use ports within the 'string of pearls' for military power projection purposes in the future. But besides a possible military use in the future, these ports are also economically important: They are of utmost importance to the transport of Arabian oil to economic powerhouses and major oil importers in Northeast Asia, mainly China, Japan, and the ROK. This is also a very important example but it remains a theory 
that China would use it to project power in the future, and thus it is secondary to the selected case.

\section{The Declaration of the East China Sea Air Defense Identification Zone ${ }^{110}$}

\section{Introduction of the Case}

The icy relationship between China and Japan since mid- to late 2012, when the conflicting claims to the Senkaku/Diaoyu islands were re-ignited, has taken its toll on the tri-lateral relations involving the U.S. as the senior partner in its alliance with Japan. In late 2013, China proclaimed a controversial air defense zone over the ECS which includes the Senkakus. ${ }^{111}$ This looming conflict — even though China feels that it has a legitimate claim to these islands, especially based on history-has the potential to spark armed aggression between China and Japan. This would mean that, according to the alliance treaty

\footnotetext{
${ }^{110}$ Parts of this sub-chapter were presented as paper at the 55th Annual Convention of the International Studies Association, Toronto, Ontario, March 26-29, 2014, at the Tenth Annual East Asia Security Symposium and Conference, Beijing, China, June 24-29, 2013, and at the 67th Annual Meeting of the New York State Political Science Association, Syracuse, New York, April 18-20, 2013. Different versions of these papers were subsequently published as "Securitization and De-Securitization in the Diaoyu/Senkaku Islands Dispute," Journal for Alternative Perspectives in the Social Sciences vol. 6, no. 2 (November 2014), pp. 219247, and "A Regional Security Complex Account of the Diaoyu/Senkaku Islands Dispute," Bond University e-Publications: East Asia Security Centre (February 2014), as well as translated into Chinese as “以地区安 全复合体理论解读钓鱼岛/尖阁诸岛冲突 [A Regional Security Complex Account of the Diaoyu/Senkaku Islands Dispute]," Bond University e-Publications: East Asia Security Centre (February 2014).

111 This may or may not be understood as China's assertive reaction in the context of the U.S. having announced its 'Pivot to Asia'/'Rebalancing' strategy. See, e.g., Adamson (2012).
} 
between the U.S. and Japan, the U.S. would join on Japan's side in such a war. Of course, this is all hypothetical, but nevertheless China's actions in this event, can and indeed must be seen as power politics. Whether the grand strategy objective of territorial integrity was violated and diverged from in this case can be argued one way and the other-depending on which side one takes. However, the upkeeping of a favorable environment for Chinaand Japan is the single country with which China does most of its trade - and the peaceful resolution of all conflicts are potentially at stake here and, by extension, a war involving the United States is a feasible risk that China (as much as Japan) is taking. Therefore, this (non-)event should be regarded as a divergence from the PD grand strategy precisely because it puts the existing peace at risk.

Still, another objective of PD may be said to have been met, that is, accommodating the rising nationalism within China and what its people postulate from the government: the rise in status and respect from others. Standing up to Japan, which was the power that last occupied China during World War II, is looked upon favorably by nationalist factions in China. Thus, while putting the peace between the U.S.-Japan alliance and China at risk diverges from PD, China may have gained in (albeit negative) respect and status from this particular event and, therefore, converged with its grand strategy. 


\section{Detailed Course of Events of the Case}

To understand the current ADIZ proclamation by China, one has to go back to former rounds of disputes over the islands between Japan and China, as well as the beginning of the current, still unresolved round of dispute. The first five instances of escalation which came in three phases of the Diaoyu/Senkaku islands territorial dispute took place after World War II in early 1970s, in the late 1970s, and the 1990s/2000s, respectively. ${ }^{112}$ Interestingly, Japan now-more than forty years after the first round of dispute_- "claim[s] that there was no formal agreement to 'shelve' or put the issue aside in 1978 and that in fact no controversy exists" (Smith 2013, 37).

The current, sixth, round of the territorial dispute can be said to have begun in 2010 when plans for the mutual exploitation of the natural resources in the ECS were again frustrated in September because of the "collision between a Chinese fishing boat and two Japanese Coast Guard vessels off the Diaoyu Islands" (Wang 2010). Japan detained the responsible Chinese captain but eventually released him after about two weeks (Fackler and Johnson 2010). China acted as a more forceful actor in this renewed dispute over the islands and — as described above — started "block[ing] crucial exports to Japan of rare earths, which are metals vital to Japan's auto and electronics industries" (Fackler and Johnson 2010), for example. China had been growing economically in strength for decades, of course, and was one of the countries whose economy came back quite quickly after the

\footnotetext{
${ }^{112}$ For a full account of the first three phases and first five rounds of disputes, see for example Danner (2014), pp. $227 \mathrm{ff}$.
} 
2008 global financial crisis. This led many in China to believe that the U.S. was now in relative decline and that China was gaining in power and, therefore, should throw its weight around internationally. One consequence was a change in policy toward the islands under analysis here to reflect this new assertiveness; as Kei Koga notes:

China's assertiveness over its territorial sovereignty is growing. It is wellknown that China has been traditionally sensitive to territorial sovereignty, notably concerning Taiwan, Tibet, and Xinjiang; yet this year, a similar level of sensitivity extended to the South China Sea and the Senkaku/Diaoyu Islands as its 'core interests'—non-negotiable interests. In fact, Chinese officials asserted in March [2010] that (...) the East China Sea, including the Senkaku/Diaoyu Islands, was newly added to the list of China's 'core' interests, according to the South China Morning Post. As China asserted in the case of the Senkaku/Diaoyu territorial dispute between Japan and China, if Beijing perceives interference of its territorial integrity by a third party, it will use any means, including diplomatic, economic and military, to defend it.

(Koga 2010)

The time during the incident and the following months were marked by nationalistic protests in both countries. Secretary of State Hilary Clinton and other U.S. government officials backed the Japanese through confirmation of the Senkakus as defendable territory under their mutual treaty. Eventually, the situation stabilized to the 
extent that a celebratory visit of a Chinese delegation to Japan commemorating forty years of official Sino-Japanese relations was planned for 2012. However, as with the earlier plans for joint development of natural resources in the ECS, something thwarted these plans.

The escalation in 2012 began with the plan of an ultranationalist Japanese group in April "to purchase the islands with cash collected in a national fund-raising campaign" (Smith 2013, 27). This, in turn, sparked activists from Hong Kong to travel to the Diaoyu/Senkaku Islands. In essence, parts of the population began to escalate the dispute in 2012. August saw many anti-Japanese protests in China and perhaps drew in the government of Japan with action of its own: As explained above, the Japanese government used to merely rent the rights on some of the Senkaku islets. "On 11 September 2012, the Japanese government signed a contract worth 2.05 billion yen ( $\$ 26.1$ million) with Kunioki Kurihara, a private businessman, to purchase three of the five main islands that constitute the Senkaku/Diaoyu Island group, an action that effectively nationalized the islands" (Smith 2013, 27). The Chinese government went on to cancel the planned celebration of four decades of Sino-Japanese relations. Whether or not the Japanese government thought that nationalizing the islands would create a precedent and eventually de-escalate the dispute remains a conjecture; Japan's actions to buy the islands certainly did the opposite and intensified the situation. The Chinese protests were destructive not only to Japanese cars and goods but also to Japanese expats living in China. On many occasions since this event, Chinese and Taiwanese military ships, including the Chinese aircraft carrier, have regularly entered the waters around the archipelago to protest Japan's purchase of the islands (Takenaka and Kaneko 2012). 
The situation continued to be precarious throughout 2013 and worsened toward the end of the year until it reached a low point in 2014. Also, the use of Chinese and Japanese names for the islands has always been controversial since the first dispute over them in the late 1960s and it remains so in this sixth round: In January 2013, a "1950 document showing that China used to view the Japan-controlled Senkakus as part of the Ryukyu Islands, or modern-day Okinawa Prefecture[, which] (...) reportedly used Japanese names, including Senkaku, to refer to the islets[,]" (Jiji 2013) was said to have been found in the diplomatic archives of the Chinese Ministry of Foreign Affairs.

In late November 2013, China unilaterally set up an ADIZ over the ECS, roughly correlating to the EEZ it claims and its continental shelf. ${ }^{113}$ The U.S., Japan, and the ROK reacted with protests. The U.S. also sent a military plane into the ADIZ. This did not really assuage this dispute but rather had the opposite effect. Otherwise, and especially before, the U.S. tried to act as a rationally de-escalating force by, for example, backing Japan with statements that armed conflict over the Senkakus would involve the United States through the alliance with Japan as recorded in the 1960 treaty (Whitlock 2012); in other words, the U.S. was and is (from its viewpoint) promoting stability in the heated dispute by supporting the balance of power in Asia in bolstering the weaker side, that of Japan: “[T]he U.S. Department of Defense announced that China's new ADIZ would in no way affect U.S. military operations in and around the East China Sea and reiterated the U.S. security commitment to Japan" (Smith 2015b, 232f.). Even though Taiwan also sent its

${ }^{113}$ See Appendix, illustration 5. 
coast guard to record its protest, the Taiwanese government tried to prevent an escalation of the dispute with the ECS Peace Initiative (Chen 2013).

The fact that China proclaimed an ADIZ was not the controversial part of the situation in late November 2013 - rather, the problem was how it did it and the geographic space it claimed:

Japan and South Korea had long maintained similar zones within which entering foreign aircraft were requested to identify themselves and their destinations. China's ADIZ, however, overlapped with those of both countries and aligned largely with the airspace above its continental shelf. Thus, China's ADIZ challenged Japan's in roughly the same way as its continental shelf claim did. Moreover, China's ADIZ included the disputed Senkaku Islands, establishing a clear contest between Chinese and Japanese air patrols over the islands. Interestingly, the new ADIZ also included an island whose sovereignty Seoul and Beijing disputed. When the South Korean government asked China to redraw its ADIZ line, Beijing refused, forcing Seoul to take a far more rigid position than it otherwise might have. Both the timing and the way in which Beijing declared it would enforce its ADIZ bothered its neighbors.

(Smith 2015b, 232f.) 
In an effort to de-escalate the situation-and not to get dragged into a war via the U.S. alliance with Japan-U.S. Vice President Biden has long been scheduled to travel to the involved parties with instructions to mend fences given that the situation had already been tense for more than a year. China obviously knew about the planned travels of Biden well in advance. Thus, it may not be by accident that "China's Ministry of Defense made [the ADIZ] announcement on November 23, 2013, just a week before U.S. Vice President Joe Biden was due to make a visit to Tokyo, Beijing, and Seoul to discuss how to alleviate regional tensions" (Smith 2015b, 232f.). As planned,

In [early] December 2013, Vice President Joe Biden traveled to Northeast Asia to try to dampen China's ADIZ ambitions and to reassert the U.S. position that it would not change its own military operations in response. But Tokyo remained skeptical of Washington's support in its contest with Beijing.

(Smith 2015b, 4)

This newest round of dispute over the Diaoyu/Senkaku Islands has so far not been resolved, and "China seems to have little interest in discussing how to reduce the risk of such close interaction between the militaries operating in the East China Sea" (Smith 2015b, 232f.). What seems to have changed is the Chinese policy, resulting from perceived relative gains in the 2008 financial crisis, with president Hu "[i]n July 2009, (...) set[ting] out a policy of 'what must be done must be done proactively' (...) signal[ling] that China no longer worries about launching disputes with other nations" (Shimbun 2014). This 
policy was maintained and fortified by President Xi as the 'Chinese Dream' (Shimbun 2014). The announced increases in military budget spending by both Japan and China also worsened the situation (Wong 2014). Some observers have alleged that Japan's PM Abe is exploiting the near-Cold War relations with China-some have described it as the low point in relations since after World War II — to realize a three-year plan that would see a constitutional restriction on the use of force in Japan removed and Japan heavily rearmed by 2015 (Takahashi 2014). Nevertheless, while not forbidding them, China tried to keep the anti-Japanese protests under relative control, although control seemed to have been lost in some cases during the height of the conflict.

\section{Localization of the Case in Terms of Honor and Legitimacy}

Given the high assertiveness in the unilateral proclamation of the ADIZ over partially Japanese-controlled maritime territory, this was surely among the most militarily relevant actions of China in the time period analyzed here. At the same time, it was also likely the closest to crisis China came with Japan and the U.S. as the main Japanese ally. Certainly China also engaged in very assertive island-building exercises in the SCS, with the difference that none of the adjacent states in the SCS is a great power. The closest U.S. territory, Guam, is thousands of miles away—even further than the Ryukyu Japanese islands - although a U.S. presence around the SCS and the Malacca Strait is not unusual as part of important sea lane protection. The island-building in the SCS-compared to the ADIZ proclamation in the ECS - was though a de facto physical claim to this maritime 
territory (besides China's historical claim). Still, next to the actual proclamation of an ADIZ over the ECS, which is a de jure proceeding, island-building is considered a technically lesser action.

Much like the case of the REE export restrictions, the main counterpart was again the neighboring Japanese arch-enemy, though with it the U.S. as a contractually close ally would be sucked into a military conflict if China acted aggressively against Japan. This sort of assertiveness is taken to another level when we deal with China, not against minor or middle powers in the SCS, but against the world's superpower and an East Asian great power to be reckoned with.

It is clear that this case relates to internal legitimacy much more than external legitimacy because China could not count on an improved reputation or recognition from other nations. Closely following the rule of territorial integrity and sovereignty relates mostly to internal legitimacy for China. Ever since the (quasi-)colonial experience from the mid-nineteenth century to the mid-twentieth century and beyond (given Hong Kong's late return in 1997), the 'Hundred Years of National Humiliation' have ingrained this sort of obsession with sovereignty into China's national genes. 


\title{
Determining Convergence with or Divergence from the PD Grand Strategy
}

\author{
Defense of territorial integrity
}

Given that the ADIZ includes territory which is in the control of (and been bought from private owners by) Japan —albeit disputed by China—the declaration of this zone is provocative on the one hand, but also clearly in defense of China's territorial integrity on the other. First, even though Japan does not acknowledge that the Senkaku (Diaoyu) Islands are disputed by China, from the Chinese point of view, the islands constitute an inherently Chinese territory and would therefore enlarge China's sovereign maritime territory further than it would without the Senkakus being Chinese. Thus, taking the Chinese point of view into account, the ADIZ proclamation is not against the stipulations of defending one's territory in its PD grand strategy and, therefore, is converging. Whether such a move was necessary is a question written on a different sheet.

Second, the Senkakus were not under Chinese control for the couple of decades after the end of World War II, when it was under American control from previous Japanese control. After this, the islands were given back to Japan for administrative control. The reality is that the Senkakus have not been under Chinese control for quite some time. Therefore, from an objective viewpoint, the action must be seen as a violation of Japan's territorial integrity and not as defending one's own territory, at least objectively. This would mean that China's behavior in declaring an ADIZ diverges from PD grand strategy. 
Therefore, this point is evaluated as China being both in convergence with and divergence from its PD grand strategy. Arguably, China only needs to answer to its own people and its national interest is served better by having declared the ADIZ rather than not. The tendency is toward this action being on the converging side but, of course, China does not rise and act in a vacuum with respect to international relations. Especially with territory as a scarce resource on earth, one also has to consider the interests and ownership claims of other nations, such as Japan. Insofar, China can be said to both diverge and converge with PD grand strategy in this case (see table 6 for an overview of analyzed divergences and convergences).

Increase of national power

Strictly speaking, since the territorial claim exceeded China's actually controlled maritime territory (i.e., cut into Japanese-controlled territory), this led to new territorial gains on China's part. Therefore, this should count as an instance in which power increased for the state of China, especially considering that this was a gain against Japan, a power to be reckoned with, and not a weak peripheral neighbor state of China. ${ }^{114}$

\footnotetext{
114 Today, it is of course often written off as antiquated way of power increase to have territorial gains but rather to see power increases in terms of economic power, technological advancement, or military strength. This can be said to have been a general trend with a censure around the end of the Second World War, i.e., the fact that the dynamics of measuring a nations power went from quantity (of territory, soldiers, population) to quality (GDP, types of weapons, technology). This is not to say that perhaps China does still think along these antiquated lines - this may very well be the case.
} 
In addition, China always claimed that this was inherently Chinese territory and never acknowledged Japanese control over the uninhabited islets. Whether this ADIZ is seen as an increase in power and not just a manifestation, or 'locking in,' of the status quo as perceived by China depends on one's perspective on the dispute. and whether one even recognizes a dispute. If that is the case, it would still not belong to the diverging category but just be a mere realization of China's grand strategy to defend its territory (or as an attempt to reunify, if one believes in the above-mentioned understanding of a power increase).

Anti-hegemonism

This category can be interpreted as converging or diverging. If one subscribes to the ADIZ as a revisionist act, this action may be understood to be against Japan since it overlaps with territory Japan considers its own, or at least it was clearly perceived by Japan and the U.S. as a provocative action. Therefore, it may be said to be directed against Japan and the American superpower's alliance. This would be classic balance-of-power strategic behavior on China's part, or 'anti-hegemonism' in China's official vocabulary, and therefore converging with its grand strategy.

Also, if one understands the ADIZ as a status quo manifestation of what China understands to be its historic borders, then its declaration is counted as perfectly converging with its grand strategy. Oana Burcu argues that 
China's ADIZ alone does not clearly signal the rise of a revisionist Chinese state. Rather, a case has been made that China is reacting to changes in its external environment and this is particularly relevant in relation to Diaoyu/Senkaku islands.

(Burcu 2014, 9)

However, if one understands China's ADIZ as a sign of non-acceptance of de facto existing borders, and therefore revisionism, then a different argument arises. Such an enlargement of Chinese borders would constitute ambitions of the Middle Kingdom to reach the status of a regional hegemon again, as it has been for so many centuries before, to restore the Sino-centric order. Thus, in case this ADIZ is one of many offensive, powermaximizing, and border-enlarging international doings by China, it would constitute pursuing hegemony itself and therefore be against the principle of anti-hegemonism (i.e., diverging from PD grand strategy).

Maintenance of favorable economic markets

While the declaration of an ADIZ may not have had a direct influence on economic markets, it certainly did not help the overall icy atmosphere that the Diaoyu/Senkaku Islands dispute had created since mid- to late 2012. Perhaps this (re-)action by China (and how it was received by Japan and the U.S.) was even critical in prolonging it another year until late 2014 when diplomatic relations between China and Japan slowly normalized again. Some repercussions transferred from this military action 
not just into diplomacy but also into the economy. As it certainly did not contribute to normalization, the declaration of the ADIZ may be counted as diverging from grand strategy.

International responsibility

Naturally, declaring an ADIZ is a defensive action at first glance, but claiming the ADIZ over what is objectively speaking Japanese territory is irresponsible and offensive — at least from a Japanese (and its U.S. ally) perspective. This may-in a way-lead to violent conflict down the road as both Japan's and China's ADIZs overlap and both may defend their maritime territory in this geographic imbrication. Thus, this would qualify as China not behaving like an internationally responsible actor. Certainly, China's goal here was to ensure national border security rather than relate to the international level. Nevertheless, China was stretching the international rules by such behavior and, since acting as an internationally responsible power is part of its grand strategy, declaring an ADIZ over foreign-controlled territory diverges from it.

\section{Avoidance of 'China threat' misperception}

This category combined with this case is not to be understood as pertaining to Japan, which is without much doubt the 'Other' to Chinese identity — and the other way around, China is the 'Other' to Japan. Thus, one can argue that this category does not apply to Sino-Japanese relations since they likely perceived each other as possible threats to begin 
with. Rather, the repercussions of this assertive action on the part of China in relations with smaller and middle powers surrounding China is of concern here-leaving foreign relations of China with Japan and even great powers such as the U.S., Russia, and India aside.

Such a clearly assertive action as declaring an ADIZ over enemy-controlled maritime territory would contribute to observers seeing China as a threat. Developments in the ECS and SCS are on a somewhat similar footing with the exception that there are no contractual (yet still partly loosely aligned) U.S. allies involved in the SCS (Vietnam, Philippines, Malaysia, Brunei, Indonesia) and, contrary to that, exceptionally close U.S. allies (ROK, Japan, ROC)—some of which have many U.S. troops on bases on the ground-in the ECS.

This assertive action then would more than likely have led to the smaller Southeast Asian nations perceiving China as a threat. China has been assertive, too, in the SCS with its so-called 'island building,' that is, bringing soil to small archipelagos there, enlarging their territory, and militarily repurposing them as stationary aircraft carriers by building runways on them. Combined with these dynamics, such an action as the ADIZ declaration in the ECS in late 2013 at least triggered fears that China would double down with a second ADIZ also for the SCS (Keck 2014) — even building up so much pressure as to force the Chinese government to react via its Xinhua state media agency to deny rumors of an ADIZ in the SCS (Xinhua 2014b); this action clearly diverges from the PD grand strategy. 
Increasing China's international reputation

This category also diverges from grand strategy: The suddenness and assertiveness of the ADIZ declaration (i.e., the fact that it was unilaterally announced without previous instructions to - at least—adjacent nations and kept secret until official announcement) does seem alarming. It by no means increased the international reputation of China. Rather, it may have rather decreased China's reputation before increasing it. Because it was perceived as a revisionist action, China's reputation cannot have been ameliorated. Often, China is seen as a future (or even current) global hegemonic successor to the U.S.- the highest possible status of a great power, or superpower. There can be global hegemons with benign (altruistic), exploitative (selfish), or mixed motives (both altruistic and selfish). Whereas the U.S. is most often seen as either a benign or mixedmotive global hegemon, such assertive and non-transparent actions by China as the ECS ADIZ declaration lead many to see an exploitative Chinese global hegemon, in case China ever gets to this high status. All in all, China diverged here from PD grand strategy. 


\begin{tabular}{|c|c|}
\hline Factor in PD & Convergence / Divergence \\
\hline Defense of territorial integrity & $\begin{array}{l}\text { Convergence \& Divergence } \\
\text { (converging if seen as defensive of borders } \\
\text { diverging if seen as quasi-border revision) }\end{array}$ \\
\hline Increase of national power & $\begin{array}{l}\text { Convergence } \\
\text { (if the territorial claim will lead to territorial } \\
\text { gains, then power may have been increased) }\end{array}$ \\
\hline Anti-hegemonism & $\begin{array}{l}\text { Convergence \& Divergence } \\
\text { (convergence if seen as vs. Japan and U.S. } \\
\text { divergence if seen to be status quo action) }\end{array}$ \\
\hline $\begin{array}{l}\text { Maintenance of favorable } \\
\text { economic markets }\end{array}$ & $\begin{array}{c}\text { Divergence } \\
\text { (this did not help the ice age atmosphere } \\
\text { with Japan and China's trade with i) }\end{array}$ \\
\hline International responsibility & $\begin{array}{l}\text { Divergence } \\
\text { (claiming an ADIZ over Japanese territory is } \\
\text { irresponsible since it could have escalated) }\end{array}$ \\
\hline $\begin{array}{l}\text { Avoidance of 'China threat' } \\
\text { misperception }\end{array}$ & $\begin{array}{c}\text { Divergence } \\
\text { (assertive behavior clearly contributed to } \\
\text { observers seeing China as a threat) }\end{array}$ \\
\hline $\begin{array}{l}\text { Improving China's international } \\
\text { reputation }\end{array}$ & $\begin{array}{c}\text { Divergence } \\
\text { (likely may have damaged China's international } \\
\text { reputation) }\end{array}$ \\
\hline
\end{tabular}

Table 6: Divergence from or convergence with PD in the case of the declaration of the ADIZ over the ECS.

\section{Alternative Explanations}

As outlined above, how the borders are interpreted and claimed determines how one assesses whether this is actually assertive, revisionist behavior or merely securing one's borders, the status quo. Should one subscribe to the latter, China's behavior perfectly converged with PD grand strategy although it likely was aware of how the behavior would be received by Japan and the U.S. (and the ROK and ROC peripherally), that is, as assertive. 
Assuming the former - that this was objectively revisionist behavior - its effect stays the same, that is, how it was received by adjacent nations, the U.S., and the international society of states.

Otherwise, there are no viable alternative explanations for the ADIZ declaration as it is a very straightforward military action to secure China's own territory, and perhaps to set a precedent to be copied in the SCS.

\section{Conclusion of Case Analysis}

This case of the ADIZ declaration clearly catered to China's internal legitimacy. On the one hand, this action went mainly against Japan (i.e., the ex-occupying nation and historical arch-enemy). Although the Diaoyu/Senkaku Islands territorial dispute was put off in several instances, to be decided by later generations, vast parts of China's nationalist-leaning population has demanded a reaction by the communist government to the purchase of islets in this ECS archipelago by the Japanese government-something that was perceived by the Chinese population and government as a very assertive and nationalist action on the part of Japan. To put China's assertive action into perspective, it was merely a reaction — along the lines of 'fight fire with fire.' Intriguingly, just when the diplomatic relations were basically put on ice after the first military showings around the Senkakus in

the fall of 2012, there would have been an important Sino-Japanese event scheduled: September 29, 2012, would have marked the fortieth anniversary of the official 
establishment of diplomatic relations between China and Japan. Such a celebration would have not boded well with hyper-nationalists in either country. Staying stubborn on the subject of the territoriality of the islands was perhaps not the fault of either nation but actually in both governments' interest with regard to internal legitimacy.

On the other hand, apart from the involved actors, the matter concerned here is for the CCP to lead China back to its erstwhile splendor, including the restoration of its borders as they were before the 'century of humiliation.' So, even without taking into account that this was an action directed against Japan, the matter and objective of the action is perfectly in line with PD grand strategy as seen from China's perspective.

Similar to the other cases of China's assertiveness relating to internal legitimacy outlined above, the cultural driver of honor was important here in relation to the one hundred years of national humiliation complex and the attendant improvements of the national reputation and prestige. However, the way in which it was done (i.e., unilaterally, suddenly, and without previous instruction for adjacent nations) is noteworthy and so is the environment of the strained atmosphere after mid- to late 2012 in which this took place. Such action as declaring an ADIZ and the way in which it was declared could easily have led to further escalation and at least contributed to an increase in the chance of violent conflict as Japan's and China's ADIZs overlapped.

All in all, this grand strategy manifestation exclusively pertained to internal legitimacy and mostly diverged from PD grand strategy for the outward-looking factor 
categories which relate to external legitimacy. Note, though, that from a Chinese viewpoint and a status quo assumption, this was perfectly defensible and converged with PD grand strategy action on the whole.

\section{The Continued Participation in United Nations Peacekeeping Missions ${ }^{115}$}

\section{Introduction of the Case}

When it comes to external legitimacy and military strategy, there is not likely to be a better case than UN PKMs since they involve both. Renowned scholar David Shambaugh calls the PKM "[p]erhaps the most noteworthy example of China's contributions to international security" (Shambaugh 2013, 271). China's participation in UN PKMs is a fairly recent development. When the UN was founded after World War II, the PRC was excluded for a long time and represented by the Republic of China (ROC; Taiwan) until the 1970s. Historically, right after the end of the Chinese Civil War, a Chinese stance developed that did not favor supporting international intervention:

China's current support for international intervention stands in contrast to its opposition to the policy during the Maoist era. This stance was partially a product of the 1950-3 Korean War, which saw Chinese volunteer forces,

\footnotetext{
${ }^{115}$ An adapted version of this chapter was accepted for publication as part of a forthcoming research article in Culture Mandala, vol. 12, no. 1.
} 
heeding Mao's call to 'Resist America. Assist Korea' (kang Mei yuan Chao 抗美援朝), by fighting alongside the communist North Koreans against South Korea, the United States and other UN forces. However, even after the Cold War China has insisted that international intervention must be guided by the UN and especially its Security Council.

(Lanteigne 2016, 10)

Nevertheless, since the PRC replaced the ROC in the UN Security Council (UNSC), it took about two decades to start reversing this strong principle for Chinese decision-makers. “Following Deng's passing, China's interest in organisations beyond economic ones increased. (...) [T] he governments of Jiang Zemin and Hu Jintao were (...) far less fearful of being victimised by security organisations in relation to China's views on UN peacekeeping" (Lanteigne 2016, 84). In all, "[s]ince the beginning of the 1990s, the PRC has also played a substantial role in UN peacekeeping missions, sending a total of 17,400 troops on nineteen separate peacekeeping missions between 1990 and the end of 2010" (Heilmann and Schmidt 2014, 25).

\section{Detailed Course of Events of the Case}

As of December 2015, China is the ninth largest contributor to UN PKMs world-wide and the largest among the UNSC permanent five members (P5). It contributed 161 police personnel, $36 \mathrm{UN}$ military experts, and 2,882 troops-more than 3,000 UN 
PKM personnel in total. This compares to the U.S.'s 82 total contributions, Russia's 79, France's 909, and the U.K.'s 289. ${ }^{116}$ Currently, China has troops deployed to UN PKMs in Liberia, Mali, Democratic Republic of Congo, South Sudan, and Lebanon, previously having deployed troops to Haiti, Libya, Iraq, Kuwait, and Cambodia. ${ }^{117}$ This engagement in UN PKMs should be valued highly by the international community because

Beijing views with deep suspicion one of the great projects of the post-Cold War international system: multilateral humanitarian intervention. (...) Beijing does not like this post-Cold War trend one bit. Sanctions and interventions against the will of sovereign states in the developing world run against China's post-1978 domestic and international ideology. (...) In this narrative, the real goal of international pressure was not the promotion of 'so-called human right' but the subjugation of China in a Westerndominated international order. With that (...), China has been very reluctant to sanction other sovereign states on such grounds, let alone allow UNbacked military intervention for the purpose of furthering humanitarian or security goals.

(Christensen 2015, 162f.)

\footnotetext{
116 See UN (2015).

${ }^{117}$ See Appendix, illustration 6.
} 
Only slowly and with increasing power and, thus, international confidence did the stance on UN PKMs change: "Finally, after harbouring much suspicion about multilateral security cooperation, Beijing has altered its views considerably since the turn of the century, favouring multilateral security cooperation in areas such as arms control agreements and United Nations peacekeeping missions" (Lanteigne 2016, 6).

The process of changing China's mind took some time: At the beginning, the PRC was not even expressly pro-UN intervention when it first inherited the seat in the UNSC from the ROC in the 1970s; after decades of change and its famous unprecedented (re-)rise to great power status, China now actively participates in UN PKMs. As Marc Lanteigne writes: "China has praised the UN's views on security-building and more recently on disarmament, and during the 1990s took a more conciliatory view on United Nations peacekeeping and humanitarian intervention. China would later match words with deeds" (2016, 78). "The origins of China's involvement date to the 1989-1992 period, when it first dispatched military observers to Africa and the Middle East, and military engineering corps to Cambodia" (Shambaugh 2013, 299).

The determining change in China's view to support UN PKMs does not mean that it abandoned its belief in the somewhat pluralist conception of territorial integrity and sovereignty:

China tries to take a traditional political approach to these missions, generally sending troops when their deployment is blessed not only by the 
United Nations but also by the home government in the nation in question. By creating those preconditions and carefully using its power at the UN Security Council to enforce them, China is able to use its PKO role to check all of the important boxes in the PRC's self-generated national identity: a responsible great power (fu zeren daguo); a leader of the developing world; and a postcolonial state with a deep respect for sovereignty.

(Christensen 2015, 163)

For a long time, it was true for Chinese deployments that "[i]n UN peacekeeping operations, the ground forces take part with engineers, logisticians, and medical personnel rather than with other combat units" (Heilmann and Schmidt 2014, 60). However, 2013 marked the first time China sent troops abroad with an actual fighting brief within a UN PKM; as Christensen explains:

Until it agreed to deploy 'blue helmets' to Mali in 2013, China had never agreed to send combat troops to PKO or stabilization missions. But China still lost fourteen peacekeeping and stabilization personnel in incidents such as Israeli air strikes in Lebanon and the earthquake in Haiti. China even trains large numbers of other countries' peacekeepers in an impressive facility outside of Beijing[.]

(Christensen 2015, 163) 
This step to cross the threshold of sending combat troops abroad marks a major change in China's attitude and actions within the UN framework.

More recently, in summer 2015, the Ministry of Defense published a white paper, 'China's Military Strategy,' in which it also lays out a plan of action vis-à-vis UN military strategy under the subheading "Fulfilling international responsibilities and obligations" (China 2015b):

China's armed forces will continue to participate in UN peacekeeping missions, strictly observe the mandates of the UN Security Council, maintain its commitment to the peaceful settlement of conflicts, promote development and reconstruction, and safeguard regional peace and security. China's armed forces will continue to take an active part in international disaster rescue and humanitarian assistance, dispatch professional rescue teams to disaster-stricken areas for relief and disaster reduction, provide relief materials and medical aid, and strengthen international exchanges in the fields of rescue and disaster reduction. Through the aforementioned operations, the armed forces can also enhance their own capabilities and expertise. Faithfully fulfilling China's international obligations, the country's armed forces will continue to carry out escort missions in the Gulf of Aden and other sea areas as required, enhance exchanges and cooperation with naval task forces of other countries, and jointly secure international [sea lines of communications]. China's armed forces will engage in 
extensive regional and international security affairs, and promote the establishment of the mechanisms of emergency notification, military risk precaution, crisis management and conflict control. With the growth of national strength, China's armed forces will gradually intensify their participation in such operations as international peacekeeping and humanitarian assistance, and do their utmost to shoulder more international responsibilities and obligations, provide more public security goods, and contribute more to world peace and common development.

(China 2015b)

Naturally, there is not much controversial substance in this part of the white paper. It does suggest, though, that China is to "intensify [its] participation in such operations as international peacekeeping and humanitarian assistance" (China 2015b). The main motive to participate in UN PKMs, as a responsible international great power, is reflected in the promise to "shoulder more international responsibilities and obligations, provide more public security goods, and contribute more to world peace and common development" (China 2015b). The mention of public security goods and world peace inevitably lead one to think of hegemony and HST, in which a benign (or mixed-motive) hegemon will provide public goods in an effort to keep the global market and international system open and stable as well as peaceful. 
Though the white paper mentions humanitarian interventions, not all present actions of China are matched with these words, as exemplified not just by its participation in interventions but also its choice not to participate:

The Selective Multilateralists have advocated raising China's participation in UN peacekeeping operations, disaster relief, fighting international piracy in the Gulf of Aden, and diplomatic involvement in the North Korean and Iranian nuclear issues; but they eschew deeper involvement in sensitive and risky areas such as Iraq, Libya, Syria, or Afghanistan. They essentially reject the entire transnational nontraditional security agenda. There remains a strong reluctance to engage in international security operations for 'humanitarian' reasons.'

(Shambaugh 2013, 40)

\section{Localization of the Case in Terms of Honor and Legitimacy}

There is some room for interpretation in what concerns honor and legitimacy in China's involvement in UN PKMs. Surely living up to the call upon China to be a more responsible international actor is where the part-taking of China is mostly aimed. In that regard, China's status as a great power is enhanced. That this is directed toward external legitimacy becomes clear when one considers the longstanding history of China's stance on non-intervention, non-interference in internal affairs, and territorial 
integrity and sovereignty as 'golden rules,' generally. It took China a long time to accept the necessity of UN PKMs, as well as endorse them. It has now become the largest contributor in terms of personnel to PKMs among the UNSC P5.

Such involvement reflects a change in Chinese views on peacekeeping missions. For a long time China regarded these missions as incompatible with its demand for unconditional respect of its territorial integrity and state sovereignty. Today, however, the PRC is prepared to support intervention, provided such operations have the backing of a UN Security Council resolution and the affected country's advance permission. Here we can clearly see a pragmatic realignment of Beijing's interests with respect to support for intervention beyond its borders (fostering the image of China as a responsible superpower, stabilization of the surrounding region, and so forth).

(Heilmann and Schmidt 2014, 25)

Any statistic on whose basis China can prove its splendor and cast a shadow on the traditional great powers at the same time helps increase its status and reputation in a positive manner-such as UN PKMs participation. For many living in developed countries (DCs), it is still a bit of a stretch to imagine a Chinese future superpower with a global presence that will act as police force the same way the U.S. has. The foreign media exposure in the framework of UN PKMs is certainly helpful in the power-transitioning process to reach people's hearts and minds to accept a benign Chinese leadership role. 
. While UN peacekeeping participation may have significantly increased China's external legitimacy vis-à-vis the other great powers, another dimension is the external legitimacy vis-à-vis the LDCs. China likes to present itself as the leader of the Third World, and as such it is helpful to slowly develop standing not just on the diplomatic and economic levels - which China has been doing maybe even to exhaustion — but also with respect to establishing security and a military foothold. That China is taking part in UN PKMs to impress LDCs more so than the P5 may be confirmed by a look at who else values contributing to UN PKMs: Next to China, the 'Top 10' of nations contributing most in total to UN PKMs are Bangladesh, Ethiopia, India, Pakistan, Rwanda, Nepal, Senegal, Ghana, and Nigeria. ${ }^{118}$

Despite contradicting a previously held position not to intervene in other countries and, thus, interfere with their internal affairs, seeing China with a global presence helps with internal legitimacy for domestic purposes. The home front understands that when China was in a relatively weak position post-World War II and post-Civil War in the 1950s, it had not much of a choice other than to condemn the 'One Hundred Years of Humiliation' and the behavior of Japan and others to semi-colonize and -subjugate China. The Chinese leadership had to develop a strong principled stand against interference in general. Now that China is powerful and to be reckoned with, the change in this stance is easily comprehensible. It cannot necessarily be interpreted as picking up on the historical legacy of the tributary system, especially if interpreted as a coercive tool which China used

${ }^{118}$ See UN (2015). 
to subjugate neighbors; but it is possible to think of UN PKM participation as a tool to help overcome the 'humiliation complex.'

Determining Convergence with or Divergence from the PD Grand Strategy

Defense of territorial integrity

While at first look this can easily be said to have no direct effect on the grand strategy factor of territorial integrity —at least what concerns the importance of China's own border security - there is another viewpoint. As China has a longstanding tradition of putting an extremely high premium on sovereignty, representing a pluralist stance in international society in English school terms, sending troops to other states where China does not claim land is partially contradictory to this stance. ${ }^{119}$ As China preached for a long time to others that no nation has the right to intrude in the internal affairs of another, the fact that it is willing to send personnel in a UN PKM can be seen as incoherent behavior. Nevertheless, China has developed clear criteria, when it participates in PKMs,

${ }^{119}$ See, e.g., Linklater and Suganami (2006, 261), Scheipers (2010, 15ff.), or Navari and Green (2013). Pluralism is the wing of international society of states which put a great emphasis on sovereignty, borders, territorial integrity and non-interference in internal affairs. The other side of international society-said to be the more progressive, western stance - is that of Solidarism, which emphasizes that territorial integrity can and should be softened in certain situations, for example when a genocide threatens to be taking place imminently. Naturally, states which suffered a similar fate as China, who were victims of colonialism and exploitation by stronger nations, usually belong to the pluralist faction, so as to prevent future intrusion into their internal affairs and secure their survival as a nation. 
and when not (i.e., when the host nation wishes that the Chinese (and UN) are present). Strictly speaking, this diverges from PD grand strategy, if one understands the territorial integrity norm very broadly, as China always has represented it (see table 7 for this case's divergence and convergence analysis). Interpreting it very narrowly-just applied to Chinese borders and territory - then China taking part in UN PKM is converging.

Increase of national power

China often understands itself as a leading nation within the collective of LDCs - what used to be called the Third World, especially in Africa where most of the UN PKMs take place. That "China contributes more than the other four permanent members of the Security Council combined" (Christensen 2015, 163) says something about the importance that it attaches to being active in those states less fortunate and seeking development. China's standing as a preeminent voice among LDCs occasionally gives it leverage over the more senior and economically advanced great powers. This is the case especially when it comes to rectifying higher $\mathrm{CO}_{2}$ emissions output for the sake of development to lift vast parts of its population out of poverty or when it comes to not abiding by certain free trade rules of the WTO when China makes use of protectionist actions such as the export restrictions on REEs. The strong footing that China has vis-à-vis UN PKMs gives it legitimacy (internally and externally) in many ways with the collective of LDCs. Thus, China's participation in UN PKMs is increasing its power-at least indirectly — and, therefore, converging with its PD grand strategy. 
Anti-hegemonism

While it seems neutral at first look that China participates in UN PKMs, there are two viewpoints to this. First, if one sees the UN as a neutral international body, then participating in a UN PKM is perfectly converging with PD grand strategy. Second, if the $\mathrm{UN}$ is interpreted as a tool of statecraft which is mainly dominated by great powers and global hegemons, and so is oppressive, then participating in a UN PKM contributes to U.S. hegemony, or at least perpetuates the sort of great power management and tutelage by the strong states in the international system. Thus, this would contradict the norm of antihegemonism and therefore diverge from PD grand strategy.

Maintenance of favorable economic markets

This category does not seem very relevant for the factor of economic markets. However, if one defines the maintenance of favorable economic markets as also keeping peace politically and militarily, then participating in a UN PKM certainly applies as converging with PD grand strategy. As China has also heavily invested in those affected countries in which UN PKMs are taking place or may take place in the future, participation in them contributes not only to an altruistic 'greater good,' but in effect also to China's own selfish, corporate interests.

International responsibility 
The factor of international responsibility is without doubt the centerpiece of the Chinese government's motivation to participate in UN PKMs. China has been called to support international peace more actively by being the 'responsible stakeholder' it should be - starting with WB President Zoellick's speech in $2005 .{ }^{120}$ On the one hand, taking on more responsibility through UN PKMs is certainly a step in the direction that Zoellick and others talked about. On the other hand, some domestic Chinese voices are convinced that "the West's call for China to play a greater role in global governance is (...) 'a trap to exhaust our limited resources!'”(Shambaugh 2013, 40; partially quoted from Pilling 2010). More on the balanced side, "Selective Multilateralists [in China] are wary of foreign entanglements, but they recognize that China must 'do some things' (as Deng Xiaoping suggested) in the international arena so as not to be perceived as [a] self-interested free rider in international affairs" (Shambaugh 2013, 40).

Avoidance of 'China threat' misperception

Avoiding others' perception of China as threatening is among the most important factors motivating its participation in UN PKMs. As Heilmann and Schmidt write, "China's initiatives in both the global and regional multilateral contexts aim to dispel fears regarding its ascent and to convey an image of a responsible superpower that believes in maintaining the status quo" (Heilmann and Schmidt 2014, 32). On the one hand, seeing China in missions which are about peacekeeping and not combat actions or island-building

\footnotetext{
${ }^{120}$ See Zoellick (2005).
} 
certainly helps with attaching a more peaceful image to the Middle Kingdom-something that its PD grand strategy was engineered to do and which is, therefore, converging with it. This is a signal mostly to smaller nations that may or may not have reason to fear China rising.

On the other hand, China's participation in UN operations and the existing U.S.-led global governance structures goes to show that it is making an honest effort to maintain international peace and, therefore, may be seen as accepting the status quo regarding global order. This sort of signal is meant not so much for the smaller states but for the great powers and hegemons that worry about the long-lasting systemic peace.

Increasing China's international reputation

In line with the factor of being a responsible stakeholder, this sort of altruistic international behavior helps increase China's reputation internationally, especially with the collective of LDCs but also with the esteemed great power elite which has been asking for a more active, less reluctant China. As explained above, UN PKM participation is likely to increase China's status and reputation with both DCs and LDCs; as Shambaugh suggests:

China has received very high marks and positive evaluations for the quality and the integrity of its personnel and contributions to PKO operations (...). They are increasingly involved in mission leadership and decision making. 
(...) All in all, China's contributions to UNPKO have been a definite 'net plus' for the UN, China, and the recipient countries. It is a tangibleperhaps the most tangible-indication of China's contribution to global governance. China's overseas disaster relief is also a significant contribution. Since the 2004 Asian tsunami, China has also contributed personnel and resources to disaster relief in Asia and other parts of the world.

(Shambaugh 2013, 299)

\begin{tabular}{|c|}
\hline Factor in PD \\
\hline Defense of territorial integrity \\
\hline Increase of national power \\
\hline Anti-hegemonism \\
\hline Maintenance of favorable economic \\
markets \\
\hline $\begin{array}{c}\text { International responsibility } \\
\text { Avoidance of 'China threat' } \\
\text { misperception }\end{array}$ \\
\hline Improving China's international \\
reputation
\end{tabular}

\section{Convergence / Divergence}

Convergence \& Divergence (converging: participation with UN mandate; diverging: interference in internal affairs)

Convergence
(cementing standing as Third World voice)

Convergence \& Divergence (converging: if UN interpreted as neutral; diverging: if UN interpreted as oppressive)

\section{Convergence}

(if defined as the maintenance of peace and therefore that of mutual trade and investment)

\section{Convergence}

(China supporting international peace by being a 'responsible stakeholder')

\section{Convergence}

(as China is participating in the existing UN and making an effort to maintain peace)

\section{Convergence} (being a 'responsible stakeholder' does improve China's reputation internationally)

Table 7: Divergence from or convergence with PD in the case of the continued participation in UN peacekeeping missions. 


\section{Alternative Explanations}

With the UN PKM, there is little doubt that it is an exercise meant to increase external legitimacy, as it took China a long time to move from its strong stand on sovereignty - a pluralist conception of the international society of states - toward a softer understanding of sovereignty that allows for intervention and peacekeeping.

That this could further facilitate economic access is most certainly a positive byproduct for the Chinese. China has been expanding into those countries in which UN PKMs become necessary since investors from DCs may shy away from investing large sums of money in countries on the verge of becoming 'failed states.' Thus, one cannot deny that the cultural driver of interest plays a role here-but nevertheless not for the purpose of determining external legitimacy.

An explanation which would erode external legitimacy is the eventual use

of the UN PKM experience for coercive purposes - even if the participation per se may seem peaceful at the time; as Heilmann and Schmidt imply in relation to talking about dualuse technology:

There is (...) a dual-use problem. Some platforms (e.g., satellite programs) can serve civilian and military purposes at the same time. Chinese engagement in peacekeeping operations abroad can provide the PLA with needed training in the far seas or indicate Beijing's commitment to UN 
norms, signaling a new concept in the use of force and the PRC's willingness to present itself as a responsible great power.

(Heilmann and Schmidt 2014, 75)

\section{Conclusion of Case Analysis}

A look at China's continued participation in UN PKMs clearly shows that honor and, in relation to it, external legitimacy are central drivers. First, taking part in PKMs enhances China's profile as a responsible great power engaging the international community. This speaks to the existing great powers which have called on China time and again to take on more responsibility. Such participation takes the steam out of that debate while helping China's status and reputation. Today, "China has arguably taken on the image and role of 'system maintainer' and 'responsible power' in the United Nations (...) and is one of the most vocal champions of the United Nations" (Shambaugh 2013, 139). Even outdoing the traditional great powers in the UNSC with troops deployed to PKMs is an intended development in line with Chinese arguments to counter accusations by the P5 of not acting like a responsible power (i.e., being able to list shortcomings versus Chinese engagement with PKMs).

Second, since China likes to present itself as the leader of the Third World, it was in some ways contradictory not to participate in PKMs in the past since doing so 
concerned LDCs for the most part. Having a stake in these PKMs with deployed troops also caters to that aspect of China's external legitimacy.

Third, and acting against the 'China threat' theory of surrounding nations scared of the Middle Kingdom given its unprecedented rise in past decades, seeing Chinese combat forces for the first time in a UN PKM in Mali helped put neighbors at ease with regard to speculation about China's future intentions. As a Chinese military advisor put it, "[p]eacekeeping is always the best [way of exercising] soft power to counter any 'threat theories' in the international [sphere]" (Chan 2014).

Fourth, subscribing to an interpretation of the tributary system in which China guaranteed the security of other states within it, or similarly the interpretation of it as a political alliance guarding against the Turkic nomad threat, participation in UN PKMs at least shows China in a 'protector' position. This may cater to the legacy of the external legitimacy of the tributary system.

As far as internal legitimacy goes, the prestige of working closely with the UN is certainly not hurtful. For a long time, China argued that as an LDC, it could not focus its efforts on problems of other remote LDCs and rather needed to fix things at home. There is potential that some aspects of China's participation would be agreeable with domestic population approval: On the one hand, China's troops being stationed overseas means that deployment of the same for militarily assertive purposes could viably be easier; 
on the other hand, China may have economic interests in those countries where China also sent troops within a PKM, possibly protecting such interest in the future. 


\section{CONCLUSION}

No society—past, present, or future — could escape contradictions, for this was a characteristic of all matter in the universe.

(Mao 1967 [1937])

It is common sense to think that emotion should be divorced from reason and can be. But that is not what science is finding. Common sense is wrong. The way the brain works, neuroscientists tell us, is that emotion and reason work together. You cannot separate them.

(Shenkman 2016, 131)

\section{Revisiting \& Generalizing from the Cases}

The similarities in the analyzed cases are striking: All of them could be contextualized within China's historical understanding of honor in the pursuit of prestige, status, recognition and reputation and the related dimension of internal and external legitimacy. However, the analysis also revealed that, within the three analyzed groups, each case-pair differed from each other in that one of them was incoherent with the identified priority factors in the PD grand strategy, especially the outward-looking factors (see table 8 for the overview of all analyzed within-cases). These outward-looking factors were not observed in those cases which related mostly to internal legitimacy, whereas when the 
analyzed events had aspects of external legitimacy, there was convergence with the PD grand strategy across the board. Diverging from the PD grand strategy usually meant exerting assertive behavior or behavior perceived by others to be threatening or aggressive.

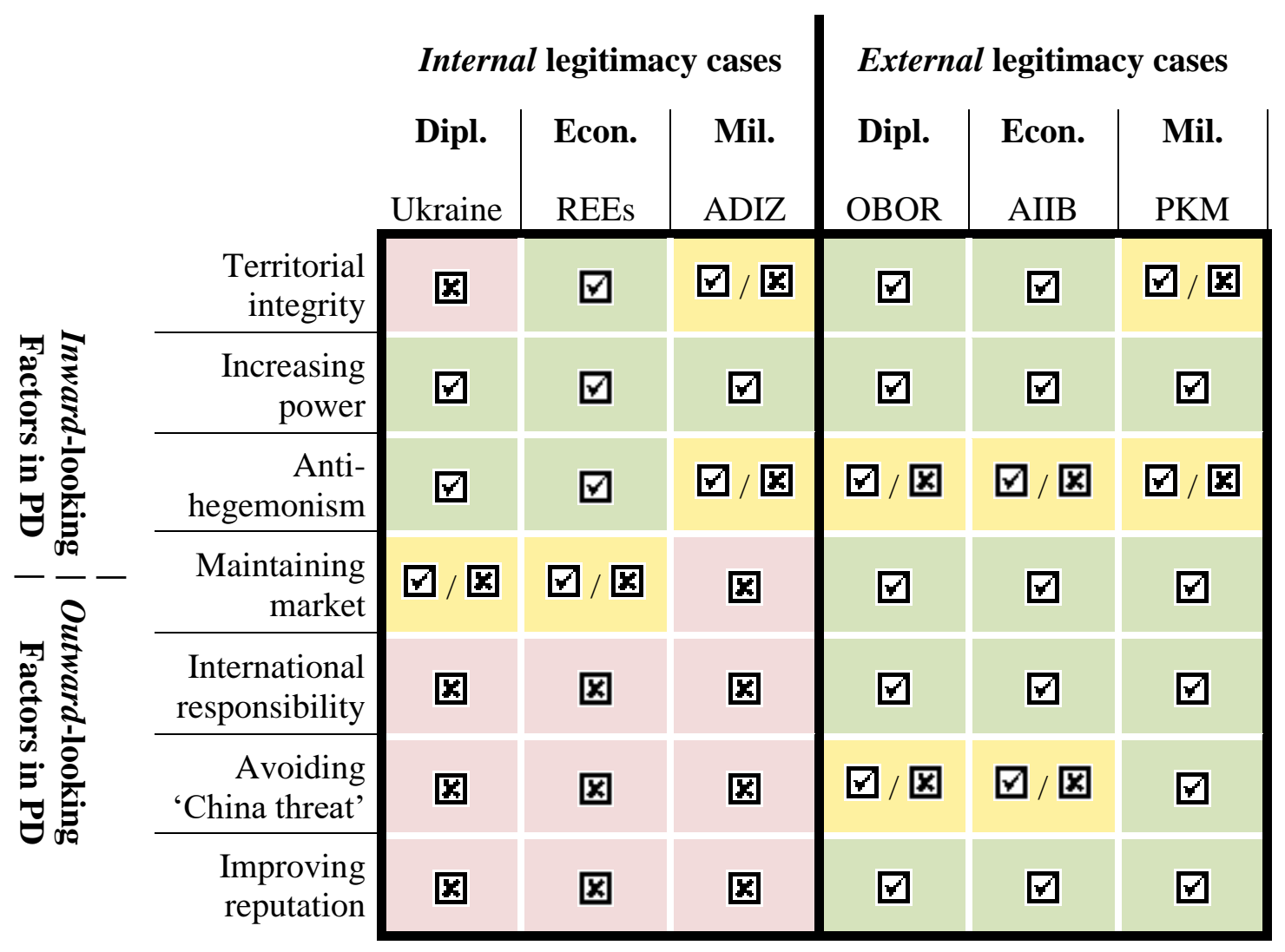

Table 8: Overview of cases concerning divergence (国) from or convergence ( $(\mathbf{\square})$ with PD, or both $(\square$ / 国).

The utilized approach focusing on cultural factors and the approach of looking at honor as a determining factor needed to be qualified and contextualized within 
the established historical link of prestige, status, reputation and recognition with the grand strategy policy input of internal and external legitimacy. On the one hand, grand strategy manifestations that are in tune with honor tend to be peaceful and tend to be related to external legitimacy or a combination of external and internal legitimacy. On the other hand, grand strategy manifestations that are not in tune with honor tend to be assertive in nature and tend to be related to only internal legitimacy.

Still, the involvement of economic interest and fear as cultural drivers in the cases in which China diverged from its grand strategy certainly cannot be denied for the analyzed cases. In the Ukraine Crisis case, China negotiated a profitable treaty with Russia and then, some time later, invested heavily in and traded more intensely than before with Ukraine. While economic interest was present, fear did not seem to play a major role, though China may have seen some benefit in keeping Russia and the EU/West at odds with each other. In terms of honor, China was able to make an impression as the senior partner of Russia, whereas it had been merely the junior partner in the Cold War. Regarding the REE, it seems clear that China's protectionist behavior drove prices up on the economic side, while this was also seen as a Chinese reaction to a perceived infringement into their sovereign waters by Japan on the security/fear side. Honor comes into play because of the 'Century of Humiliation' complex and the perception of Japan's occupation of China's own sovereign territory. In the ADIZ over the ECS case, supposed gas and oil deposits below the seabed speak to economic interest, whereas the obsession over territorial integrity as well as the 'second island chain' relate to security considerations. Honor and status play a similar role here as in the REE case. Despite the inevitable involvement of 
economic interest and fear, honor, in relation with legitimacy, can best explain the contradictory nature of grand strategy manifestations in China.

Overall, the analysis of these most salient events related to the manifestation of China's grand strategy showcases the fact that one's standpoint can make a significant difference in determining divergence from or convergence to a grand strategy. What became clear, however, is that within cases that related to internal legitimacy exclusively, there was more divergence from the PD grand strategy and therefore also more assertiveness. Conversely, in the cases relating either solely or mainly to external legitimacy, China tended to converge with the PD grand strategy.

\section{Revisiting the Hypotheses}

The first hypothesis, stating that the grand strategy is internally incoherent if policy diverges from or is incongruent with China's standard of national honor, held partially true for the three within-case studies analyzed in which internal incoherence of the PD grand strategy was actually present. In these three analyzed incoherent events (Ukraine crisis, REEs, ADIZ), what led to the incongruence of the grand strategy was not complete incongruence between policy and honor but rather incongruence of policy with some aspects of China's standard of national honor as it pertains to domestic/internal legitimacy (see table 9 for an overview of the analyzed hypotheses and outcomes). 
The second hypothesis, stating that the grand strategy is internally coherent if policy is consistent or congruent with China's sense of national honor, proved to be again partially confirmed in the three events with incoherence (Ukraine crisis, REEs, ADIZ) for the reasons mentioned above, whereas it was completely confirmed for the three cases (OBOR, AIIB, UN PKM) in which grand strategy was in fact coherent. In these latter cases, aspects of China's standard of national honor in both internal and external legitimacy were observed and therefore congruence with an internally coherent grand strategy resulted as a consequence.

\begin{tabular}{|c|c|c|c|c|c|c|}
\hline & \multicolumn{3}{|c|}{ Internal legitimacy cases } & \multicolumn{3}{|c|}{ External legitimacy cases } \\
\hline & Dipl. & Econ. & Mil. & Dipl. & Econ. & Mil. \\
\hline & Ukraine & REEs & ADIZ & OBOR & AIIB & PKM \\
\hline $\begin{array}{r}\text { H1: Grand strategy } \\
\quad \neq \text { honor }=> \\
\text { incoherent }\end{array}$ & 曰/因 & 曰/因 & 口/国 & $\mathbf{n} / \mathbf{a}$ & $\mathbf{n} / \mathbf{a}$ & $\mathbf{n} / \mathbf{a}$ \\
\hline $\begin{array}{r}\mathrm{H} 2: \text { Grand strategy } \\
=\text { honor }=> \\
\text { coherent }\end{array}$ & 曰/国 & 曰/图 & 曰/国 & $\square$ & $\nabla$ & $\nabla$ \\
\hline $\begin{array}{r}\text { H3: External } \\
\text { legitimacy }=> \\
\text { peaceful }\end{array}$ & $\mathbf{n} / \mathbf{a}$ & $\mathbf{n} / \mathbf{a}$ & $\mathbf{n} / \mathbf{a}$ & $\nabla$ & $\nabla$ & $\nabla$ \\
\hline $\begin{array}{r}\text { H4: Internal } \\
\text { legitimacy }=> \\
\text { assertive }\end{array}$ & 口 & $\nabla$ & 曰 & 目 & 目 & 目 \\
\hline
\end{tabular}

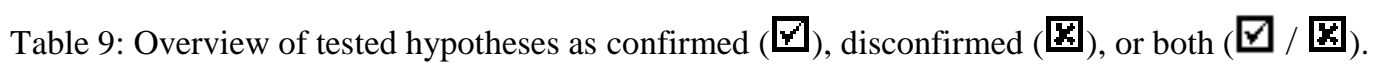


The third hypothesis, stating that China will tend to use peaceful means if its goal is enhancing external legitimacy, was corroborated by those three cases in which peaceful means were used while advancing mainly external legitimacy (OBOR, AIIB, UN PKM). It did not apply to the other three cases (Ukraine crisis, REEs, ADIZ), in which solely internal legitimacy was advanced.

The fourth hypothesis, stating that China will tend to use assertive means if the goal is enhancing internal legitimacy, was corroborated for the three within-case studies that enhanced only internal legitimacy (Ukraine crisis, REEs, ADIZ) but was not confirmed for the three cases (OBOR, AIIB, UN PKM) in which not only external but also internal legitimacy was furthered. In these latter three cases, China did not resort to assertive means.

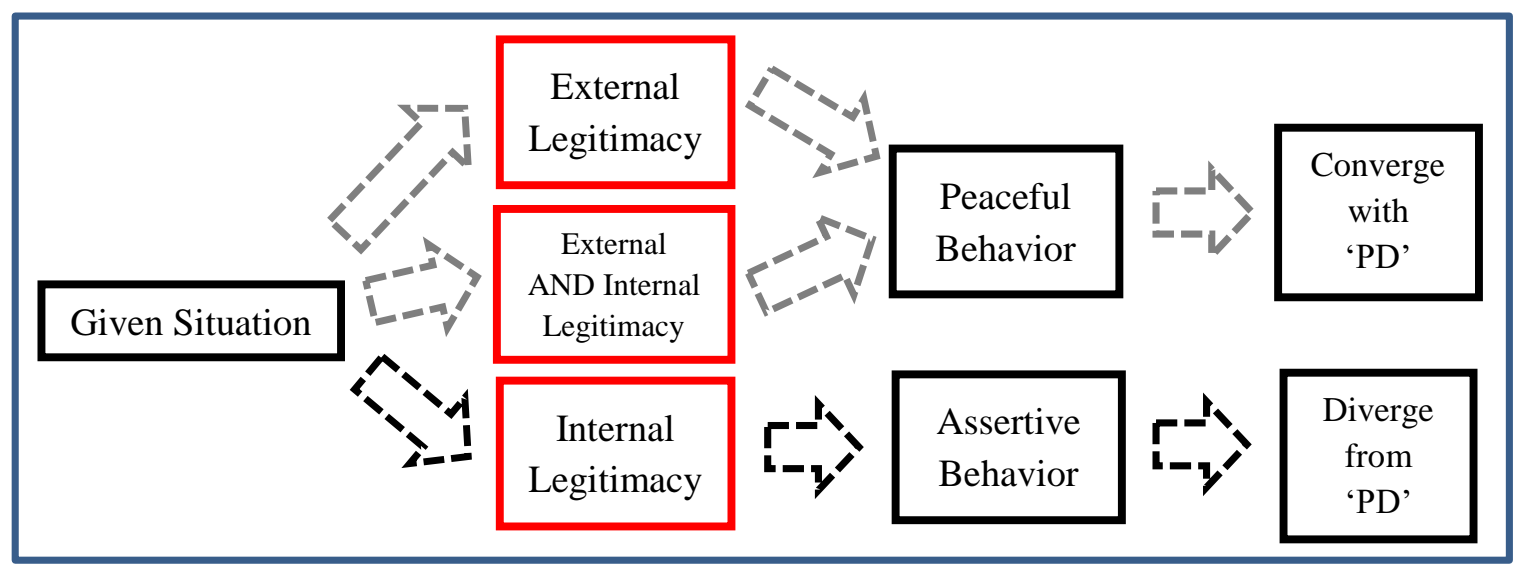

Figure 2: The Role of Legitimacy.

In testing these four hypotheses, a rather clear situational answer came to the fore through the analysis (see figures 2 and 3): If a grand strategy manifestation is 
related to internal legitimacy only, then assertive behavior and potential threat of the use of force leads China to diverge from PD and thus eventually to move toward an incoherent grand strategy. Further, if a grand strategy manifestation is related to external legitimacy only, then peaceful behavior is prevalent, and therefore the grand strategy is coherent. Finally, if a grand strategy manifestation is related to a combination of both internal and external legitimacy, then there is also likely to be peaceful behavior and therefore a coherent grand strategy.

If internal legitimacy, then always assertive. + If assertive, then always internal legitimacy.

If external legitimacy, then always peaceful. + If peaceful, then always external legitimacy. If both external and internal legitimacy, then always peaceful.

Figure 3: Situational Findings.

\section{Implications for Theory}

On a theoretical level, this dissertation agrees with studies such as those of Thomas Christensen and Christopher Layne in that domestic factors (legitimacy) matter greatly and impact the country's grand strategy. Second, this dissertation finds that grand strategy manifestations need to be contextualized within domestic factors as well as cultural/historical factors. Only then can an originally Western theory be adapted to a non- 
Western case. Third, the analysis showed the general importance of ideational factors, which may be applicable for Western country analysis as well.

Precisely this is exemplified by the fact that when China's grand strategy manifestations focus on internal legitimacy, the outward-looking factors are completely ignored and coherence with the PD grand strategy is broken. In these cases of internallegitimacy-related manifestations, inward-looking factors of PD are more likely to be adhered to, especially as seen from China's own perspective. On the other hand, externallegitimacy-related manifestations are by and large always coherent with the PD grand strategy in terms of both inward- and outward-looking factors.

In the normative debate over whether all great powers have a visible grand strategy or whether there can be no grand strategy or multiple grand strategies employed at the same time, the results show that China has overwhelmingly kept to its grand strategy core priorities. These main aims of the PD grand strategy could be clearly identified in most analyzed events.

Debating whether or not countries always act rationally, or whether it is too simple to make a clear distinction between emotion and rationality, this study suggests that the answer depends on one's viewpoint; that is, even if China's actions might seem irrational to a foreign nation, they are perfectly rational to China at all times. On the one hand, this can be easily explained by the fact that foreign nations will not naturally take China's internal legitimacy, honor, or other intangible factors into account but rather will 
decide that, materialistically speaking, China's behavior was irrational at times. On the other hand, acting in consideration of honor and in pursuit of status, reputation, recognition, and prestige, as well as the related legitimacy, can be perfectly rational from China's perspective. Nonetheless, emotion also plays into China's self-perceived rational actions via the 'Century of Humiliation' complex and the desire to once again rise to the historical role of regional hegemon, earning the respect of the other great powers. What political psychologists have recently termed 'emotion-driven' rationality therefore comes closest to the findings of this dissertation. ${ }^{121}$

Regarding the debate over whether culture (in this analysis, the related cultural driver of honor) should be considered a variable or a constant, this study finds that the generally held belief that culture is a constant applies in this case. Since the historical experience of having been a regional hegemon for many centuries until the recent 'Century of Humiliation' has been ingrained in China's political culture and historical memory, its preferences about external and internal legitimacy follow from that experience. Thus, it is only natural for China to diverge in some situations (i.e., in those associated with internal legitimacy) from its PD grand strategy.

${ }^{121}$ See, e.g., Shenkman (2016). 


\section{Implications for Policy}

In terms of implications for U.S. foreign policy, China's actions need to be filtered through a legitimacy 'lens,' which may allow some apparent threats to be called out as 'bluffs.' Regarding China's policies and grand strategy implications, this dissertation finds that China's PD grand strategy is mainly intended to apply to China's projection into the outside world and therefore to its external legitimacy or a combination of external legitimacy and internal legitimacy; however, it is certainly not designed for internal legitimacy by itself.

Similarly, the need for policy-makers to be more attuned to the culture and history of any given country, including China, is touched upon in this dissertation, especially the pursuit of status by many countries. Also, more generally, China is set to become more important for policy-makers in Washington, D.C., over the next few years and decades. As the Assistant Secretary of Defense for Strategy, Plans and Capabilities Robert M. Scher puts it, "For the past fifteen years the Pentagon has been absorbed in complex and difficult counterinsurgency campaigns, but China and Russia are again looming as the principal risks for national security" (Studies 2016). 


\section{Implications for a Possible Re-Evaluation of the (Un-)Peaceful Rise of China Debate}

The question of whether or not China can rise peacefully is one of the most important ones of our time. The PD grand strategy was specifically developed to alleviate the fears of those that believed China would be a threat to them with its increasing economic and military capabilities. Whether China's rising assertiveness since 2008/2009 is a long-term move away from its PD grand strategy and therefore an indication that China cannot rise peacefully remains to be seen. However, the general trend is that China still maintains its official PD grand strategy but merely has begun to take a more pro-active approach than before-moving away from Deng Xiaoping's 'biding one's time' motto. This is largely due to the altered Chinese perception since the 2008 global financial crisis that China's time may now have come because the crisis originated in the U.S. and China was not too deeply impacted by it.

This dissertation does not observe any switch to a different grand strategy as purported by some scholars. Rather, China's style of conducting the same grand strategy became more proactive and at times more assertive due to the above-mentioned Chinese self-perception. If there ever was an age of 'pragmatism' in China's grand strategy, then it stopped the latest after 2008. Since then, a coming 'ideological war' with the U.S. has come to appear more likely, now that China is no longer in a position to need to fully accommodate the West. 
While the domestic factor of the generational change in the Chinese leadership from Hu Jintao to Xi Jinping may have accelerated this coming 'idealogical war,' it seems clear that the main trigger was the international environment of the global financial crisis of 2008. While Qin Yaqing's assertion that zhongyong, or a middle/balanced way, is a good and cultural way to think about Chinese grand strategy contradictions may have been helpful to visualize the changing environment for China's grand strategy, what the world witnessed after 2008 was not a shift from one grand strategy to another but, at most, a paradigm change. 


\section{BIBLIOGRAPHY}

\section{Works Cited}

\section{Primary sources / Government documents}

Bank, Asian Infrastructure Investment. 2016a. AIIB - Asian Infrastructure Investment Bank. Beijing: Asian Infrastructure Investment Bank; available online at http://www.aiib.org. . 2016b. Signing and Ratification Status of the AOA of the AIIB. Beijing: Asian Infrastructure Investment Bank; available online at http://www.aiib.org/html/2015/Signing_Ratification_1118/33.html.

China, State Council of the People's Republic of. 2015. The Belt and Road Initiative. December 22. Beijing: Information Office of the State Council of the People's Republic of China; available online at http://english.gov.cn/beltAndRoad/.

- 2012. Situation and Policies of China's Rare Earth Industry. June 20. Beijing: Information Office of the State Council of the People's Republic of China; available online at http://news.xinhuanet.com/english/business/201206/20/c_131665123.htm.

2011. China's Peaceful Development. September 6. Beijing: Information Office of the State Council of the People's Republic of China; available online at http://in.chineseembassy.org/eng/zt/peaceful/t855717.htm.

2005. China's Peaceful Development Road. December 12. Beijing: Information Office of the State Council of the People's Republic of China; available online http://unpan1.un.org/intradoc/groups/public/documents/APCITY/UNPAN023152.pdf.

China, Ministry of Defense of the People's Republic of. 2015b. China's Military Strategy. May 26. Beijing: Information Office of the State Council of the People's Republic of China; available online at http://eng.mod.gov.cn/Database/WhitePapers/201505/26/content_4586715.htm.

China, The Central People's Government of The People's Republic of. 2015c. Report on the Work of Government, 2000-2014. Beijing: The Central People's Government of The People's Republic of China; available online at http://www.gov.cn/english/official/workreports.htm. 
China, Ministry of Foreign Affairs of the People's Republic of. 2014. Ambassador to Germany Shi Mingde Gives Exclusive Interview to "Der Tagesspiegel": "The Main Line Is Reform." March 25. Beijing: Ministry of Foreign Affairs of the People's Republic of China; available online at http://www.fmprc.gov.cn/mfa_eng/wjb_663304/zwjg_665342/zwbd_665378/t116522 5.shtml.

2014b. The Central Conference on Work Relating to Foreign Affairs was Held in Beijing. November 29. Beijing: Ministry of Foreign Affairs of the People's Republic of China; available online at http://www.fmprc.gov.cn/mfa_eng/zxxx_662805/t1215680.shtml.

Commission, National Development and Reform, Ministry of Foreign Affairs, and Ministry of Commerce of the People's Republic of China with State Council Authorization. 2015. Vision and Actions on Jointly Building Silk Road Economic Belt and $21^{\text {st }}$-Century Maritime Silk Road. March 28. Beijing: National Development and Reform Commission (NDRC); available online at http://en.ndrc.gov.cn/newsrelease/201503/t20150330_669367.html.

International Monetary Fund. 2015. "Chinese Renminbi to Be Included in IMF's Special Drawing Right Basket," IMF Survey, December 1; available online at http://www.imf.org/external/pubs/ft/survey/so/2015/NEW120115A.htm.

UN. 2015. "Troop and Police Contributors. United Nations Peacekeeping," UN.org, December 31; available online at http://www.un.org/en/peacekeeping/resources/statistics/contributors.shtml.

World Trade Organization. 2015. China-Measures Related to the Exportation of Rare Earths, Tungsten and Molybdenum. May 20; available online at https://www.wto.org/english/tratop_e/dispu_e/cases_e/ds431_e.htm.

. 2015. China-Rare Earths. June 22; available online at https://www.wto.org/english/tratop_e/dispu_e/cases_e/1pagesum_e/ds431sum_e.pdf.

Zoellick, Robert B. 2005. "Whither China: From Membership to Responsibility?" U.S. Department of State Archive: Information released online from January 20, 2001 to January 20, 2009, September 21; available online at http://20012009.state.gov/s/d/former/zoellick/rem/53682.htm. 


\section{Secondary literature}

Adamson, Timothy. 2013. China's Response to the US Asia-Pacific 'Rebalance' and Its Implications for Sino-US Relations. Unpublished thesis. Washington, DC: The Elliott School of International Affairs of the George Washington University.

Ahrari, Ehsan M. 2011. The Great Powers Versus the Hegemon. Basingstoke \& New York: Palgrave Macmillan.

Ambrosetti, Massimo. 2012. Power and Influence: Ideational and Material Factors in the International Posture of China Rising as a Great Power. Washington, DC: Department of Liberal Studies of the Georgetown University.

Aron, Raymond. 2003 [1966]. Peace and War: a theory of International Relations. New Brunswick, NJ: Transaction Publishers.

Baggiani, Gregorio. 2015. "China-Ukraine Relations After Crimea," China Brief 15, no. 15 (July 31); available online at http://www.jamestown.org/programs/chinabrief/single/?tx_ttnews[tt_news]=44243\&c Hash=dbc66ec1608ca6a399ee2788e9b889fe\#.Vnmhz1JpvK0.

Balaam, David N., and Bradford L. Dillman. 2013. Introduction to International Political Economy. $6^{\text {th }}$ Edition. Upper Saddle River, NJ: Pearson.

Beach, Derek, and Rasmus Brun Pedersen. 2013. Process-Tracing Methods: foundations and guidelines. Ann Arbor, MI: University of Michigan Press.

Bell, Daniel A. 2008. China's New Confucianism: politics and everyday life in a changing society. Princeton, NJ: Princeton University Press.

, ed. 2007. Confucian Political Ethics. Princeton, NJ: Princeton University Press.

2006. Beyond Liberal Democracy: political thinking for an East Asian context. Princeton, NJ: Princeton University Press.

, and Chae-bong Ham. 2003. Confucianism for the Modern World.

Cambridge: Cambridge University Press.

Bergeijk, Peter A.G. van, Maaike Okano-Heijmans, and Jan Melissen, eds. 2011. Economic Diplomacy: economic and political perspectives. Leiden, The Netherlands: Koninklijke Brill. 
Billioud, S., and J. Thoraval. 2009. "Lijiao: the return of ceremonies honoring Confucius in mainland China," China Perspectives, no. 4: 82-100.

Blank, Stephen. 2015. "Why China is winning the war in Ukraine," The World Today 71, no. 6 (December); available online at https://www.chathamhouse.org/publication/twt/why-china-winning-war-ukraine.

Booth, Ken. 1979. Strategy and Ethnocentrism. London: Croom Helm.

Brands, Hal. 2014. What Good is Grand Strategy? Power and purpose in American grand strategy from Harry S. Truman to George W. Bush. Ithaca, NY: Cornell University Press.

Bull, Hedley. 2012. Anarchical Society: A Study of Order in World Politics, Fourth Edition. New York: Palgrave Macmillan.

and Adam Watson. 2014 [1984]. The Expansion of International Society. Oxford: Oxford University Press.

Buzan, Barry. 2014. "The Logic and Contradictions of 'Peaceful Rise/Development' as China's Grand Strategy," The Chinese Journal of International Politics, vol. 7, no. 4 (Winter), pp. 381-420; available online at http://cjip.oxfordjournals.org/content/early/2014/06/03/cjip.pou032.full.pdf+html.

2010. "China in International Society: is 'peaceful rise' possible?" Chinese Journal of International Politics, vol. 3, no. 1, pp. 29-33.

Cabestan, Jean-Pierre. 2011. "China's Relations with the Major Powers: the United States, European Union, and Russian Federation," in Charting China's Future: domestic and international challenges. David Shambaugh, ed. Abingdon, UK: Routledge, pp. 77-85.

Callahan, William A. 2013. China Dreams: 20 visions of the future. Oxford: Oxford University Press.

2004. "National Insecurities: Humiliation, Salvation, and Chinese Nationalism," Alternatives, vol. 29, pp. 199-218.

Chan, Hok-lam. 1984. Legitimation in Imperial China: discussions under the Jurchen-Jin dynasty (1115-1234). Seattle: University of Washington Press.

Chen Dingding. 2015. "One Belt, One Road, One Frenzied Debate," The Diplomat, June 24; available online at http://thediplomat.com/2015/06/one-belt-one-road-onefrenzied-debate/. 
2014. "Selective Leadership: China's New Grand Strategy," paper presented at the Fourth Global International Studies Conference of the World International Studies Committee, Frankfurt/Main, Germany, August 6-9.

Chen, Edward I-hsin. 2013. "ECSPI, Rebalance, and Taiwan's Opportunities," Paper presented at the International Conference on 2013 East China Sea Maritime Security. Taibei, Taiwan, ROC, August 5.

Christensen, Thomas J. 2015. The China Challenge: shaping the choices of a rising power. New York: W. W. Norton.

. 2011. "Advantages of an Assertive China - Responding to Beijing's Abrasive Diplomacy," Foreign Affairs, vol. 90, no. 2 (March/April), pp. 54-67.

- 1995. Useful Adversaries: grand strategy, domestic mobilization, and Sino-American conflict, 1947-1958. Princeton: Princeton University Press.

Chun Hae-jong. 1968. "Sino-Korean Tributary Relations in the Ch'ing Period." in The Chinese World Order: Traditional China's Foreign Relations. John K. Fairbank, ed. Cambridge, MA: Harvard University Press.

Chung Yong-hwa. 2006. "Chosuneui Jogong Cheje Inshikgwa hwalyong [Chosun Dynasty's perception and utilization on the tribute system]." Hankookjeongchioegyosanonchong 27, no. 2, pp. 5-31.

Churchman, Kyle. 2015. "China's Vision for a New Asian Economic and Political Order," The National Bureau of Asian Research, December 22; available online at http://nbr.org/research/activity.aspx?id=637.

Clark, Ian. 2011. Hegemony in International Society. Oxford, U.K.: Oxford University Press.

Clausewitz, Carl von. 2012 [1874]. On War. J.J. Graham, transl. North Charleston, NC: CreateSpace Independent Publishing.

Clinton, W. David. 1994. The Two Faces of National Interest. New Orleans: Louisiana State University Press.

Conolly, Chris, and Jörn-Carsten Gottwald. 2013. "The Long Quest for an International Order with Chinese Characteristics: a cultural perspective on modern China's foreign policies," Pacific Focus, vol. 28, no. 2: 269-293. 
Danner, Lukas K. 2014. "Securitization and De-Securitization in the Diaoyu/Senkaku Islands Dispute," Journal for Alternative Perspectives in the Social Sciences 6, no. 2 (November 2014), pp. 219-247.

Ding Min, and Xu Jie. 2015. The Chinese Way. Abingdon, UK: Routledge.

Dollar, David. 2015. "China's rise as a regional and global power: The AIIB and the 'one belt, one road," Brookings; available online at http://www.brookings.edu/research/papers/2015/07/china-regional-global-powerdollar.

Dueck, Colin. 2006. Reluctant Crusaders: power, culture, and change in American grand strategy. Princeton, NJ: Princeton University Press.

Eckstein, Harry. 1975. "Case Studies and Theory in Political Science," in Handbook of Political Science. Volume 7. Fred Greenstein, and Nelson Polsby, eds. Reading, MA: Addison-Wesley: 79-138.

Economy, Elizabeth. 2012. "Time for a Strategic Reset," Americas Quarterly 6, no. 1 (Winter 2012), pp. 52-59; available online at http://americasquarterly.org/economy.

Eoyang, Eugene. 2006. "Of 'Invincible Spears and Impenetrable Shields': The Possibility of Impossible Translations," David C. Lam Institute for East-West Studies (LEWI) Working Paper Series, Working Paper no. 49; available online at http://lewi.hkbu.edu.hk/WPS/49_Eoyang.pdf.

Fan, Ruiping, ed., with Erika Yu (2011). The Renaissance of Confucianism in Contemporary China. New York: Springer.

Fenby, Jonathan. 2008. Modern China: the fall and rise of a great power, 1850 to the present. New York: Ecco.

Feng Huiyun. 2009. "A Dragon on Defense: Explaining China's Strategic Culture," in Strategic Culture and Weapons of Mass Destruction. Jeannie L. Johnson, Kerry M. Kartchner, and Jeffrey A. Larsen. New York: Palgrave Macmillan.

2007. Chinese Strategic Culture and Foreign-Policy Decision-Making: Confucianism, Leadership and War. New York: Routledge.

Freyberg-Inan, Annette, Ewan Harrison, and Patrick James, eds. 2009. Rethinking realism in IR: between tradition and innovation. Baltimore: Johns Hopkins University Press.

Gabuev, Alexander. 2015. "A 'Soft Alliance'? Russia-China Relations after the Ukraine Crisis," European Council on Foreign Relations - Policy Brief, no. 126 (February); 
available online at http://www.ecfr.eu/page/-/ECFR126_-_A_Soft_Alliance_RussiaChina_Relations_After_the_Ukraine_Crisis.pdf.

Gagliardi, Gary. 2012. The Warrior Class: Sun Tzu's The Art of War as 306 Lessons in Strategy. Seattle: Clearbridge Publishing.

Gao Zhiguo, and Jia Bingbing. 2013. "The Nine-Dash Line in the South China Sea: History, Status, and Implications," The American Journal of International Law 107, no. 1 (January), pp. 98-124.

George, Alexander, and Andrew Bennett. 2005. Case Studies and Theory Development in the Social Sciences. Boston: The MIT Press.

Goldstein, Avery. 2005. Rising to the Challenge: China's grand strategy and international security. Stanford: Stanford University Press.

Gong Dehong, Li Qiufa, and Gao Minzheng. 1998. Deng Xiaoping Waijiao Zhanlue Sixiang Yanjiu. Beijing: Lantian Chubanshe.

Gong, Gerrit W. 1984. The Standard of Civilization in International Society. Oxford: Oxford University Press.

Gray, Colin S. 2013. "Review Article: The Strategic Anthropologist," International Affairs, vol 89, no. 5, pp. 1285-1295.

Gries, Peter Hays, Zhang Qingmin, Yasuki Masui, and Lee Yong Wook. 2009. "Historical Beliefs and the Perception of Threat in Northeast Asia: Colonialism, the Tributary System, and China-Japan-Korea Relations in the Twenty-First Century," International Relations of the Asia-Pacific, vol. 9, pp. 245-265.

Harding, Harry. 2013. "American Visions of the Future of U.S.-China Relations," in Tangled Titans. David Shambaugh, ed. Lanham, MD: Rowman \& Littlefield Publishers.

He, Yinan. 2007. "Remembering and Forgetting the War: Elite Mythmaking, Mass Reaction, and Sino-Japanese Relations, 1950-2006," History \& Memory, vol. 19, no. 2 , pp. 43-74.

Heilmann, Sebastian, and Dirk H. Schmidt. 2014. China's Foreign Political and Economic Relations: an unconventional global power. Lanham, MD: Rowman \& Littlefield.

Hill, Christopher. 2013. The National Interest in Question: foreign policy in multicultural societies. Oxford: Oxford University Press. 
Ho, N. 2009. "Unlikely Bedfellows?: Confucianism, the CCP, and the resurgence of guoxue," Harvard International Review, vol. 31, no. 2: 28-31.

Hsiao, Hsin-Huang Michael, and Cheng-Yi Lin. 2009. Rise of China; Beijing's strategies and implications for the Asia Pacific. New York: Routledge.

Hu, Angang. 2011. China in 2020: a new type of superpower. Washington, D.C.: Brookings Institution Press.

Huang, Paul An-hao. 2010. The Maritime Strategy of China in the Asia Pacific Region: origins, development and impact. Lewiston, NY: Edwin Mellen Press.

Huang Chiung-Chiu. 2012. Harmonious Intervention: pragmatism and political culture of China's East Asian order. Unpublished dissertation. Denver: Josef Korbel School of International Affairs of the University of Colorado.

Huisken, Ronald. 2010. Introducing China: the world's oldest great power charts its next comeback. Canberra: Australian National University E-Press.

Hyer, Eric. 2015. The Pragmatic Dragon: China's grand strategy and boundary settlements. Vancouver: University of British Columbia Press.

Ikenberry, G. John. 2013. "The Rise of China, the United States, and the Future of the Liberal International Order," in Tangled Titans. David Shambaugh, ed. Lanham, MD: Rowman \& Littlefield Publishers.

Jerdén, Björn. 2014. "The Assertive China Narrative: Why is is Wrong and How So Many Still Bought Into it," Chinese Journal of International Politics, vol. 7, no. 1 (Spring), pp. 47-88.

Jiang Yang. 2011. “'Great Power Style' in China's Economic Diplomacy: Filling the Shoes of a Benign Hegemon?" in Economic Diplomacy: economic and political perspectives. Van Bergeijk, Peter A.G., Maaike Okano-Heijmans, and Jan Melissen, eds. Leiden, The Netherlands: Koninklijke Brill

Johnston, Alastair Iain. 1995. Cultural Realism: strategic culture and grand strategy in Chinese history. New York: Columbia University Press.

Jones, Bruce D., and David Steven. 2014. The Risk Pivot: great powers, international security, and the energy revolution. Washington, D.C.: Brookings Institution Press.

Kane, Thomas M. 2002. Chinese Grand Strategy and Maritime Power. London: Psychology Press. 
Kang, David C. 2010. East Asia before the West: five centuries of trade and tribute. New York: Columbia University Press.

2003. "Hierarchy and Stability in Asian International Relations," in International Relations Theory and the Asia-Pacific. G. John Ikenberry, and Michael Mastanduno, eds. New York: Columbia University Press.

Kaplan, Robert D. 2015. Asia's Cauldron: The South China Sea and the End of a Stable Pacific. New York: Random House.

Kapstein, Ethan B., and Michael Mastaduno, eds. 1999. Unipolar Politics: realism and state strategies after the Cold War. New York: Columbia University Press.

Kawashima, Shin. 2011. "The Development of the Debate Over 'Hiding One's Talents and Biding One's Time' (taoguan yanghui)," Asia-Pacific Review, vol. 18, no. 2, pp. 14-36.

Kay, Sean. 2015. Global Security in the Twenty-First Century: the quest for power and the search for peace. Lanham, MD: Rowman \& Littlefield.

Kim, Key-hiuk. 1980. The Last Phase of the East Asian World Order. Berkeley, CA: University of California Press.

Kissinger, Henry A. 2012. "The Future of U.S.-Chinese Relations: conflict is a choice, not a necessity," Foreign Affairs, vol. 91, no. 2 (March/April), pp. 44-55.

Kliman, Daniel M. 2014. Fateful transitions: how democracies manage rising powers, from the eve of World War I to China's ascendance. Philadelphia: University of Pennsylvania Press.

Kohli, Atul, Peter Evans, Peter J. Katzenstein, Adam Przeworski, Susanne Hoeber Rudolph, James C. Scott, and Theda Skocpol. 1995. "The Role of Theory in Comparative Politics: A Symposium.” World Politics, vol. 48, no. 1, pp 1-49.

Koga, K. 2010. "East Asia's Territorial Disputes: time for preventive diplomacy." RSIS Commentaries, no. 134, October 27; available online at http://dr.ntu.edu.sg/bitstream/handle/10220/6684/RSIS1342010.pdf?sequence=1.

Lanteigne, Marc. 2016. Chinese Foreign Policy. Third edition. Abingdon, UK: Routledge.

Layne, Christopher. 2009. "The Influence of Theory on Grand Strategy: The United States and a rising China," in Rethinking realism in IR: between tradition and innovation. Freyberg-Inan, Annette, Ewan Harrison, and Patrick James, eds. Baltimore: Johns Hopkins University Press, pp. 103-135. 
Lebow, Richard Ned. 2009. A Cultural Theory of International Relations. Cambridge: Cambridge University Press.

Lee Ta-Ying. 1973. "Confucius and Communism (Review: Lucian W. Pye, China: an introduction, Boston: Little, Brown, and Co., 1972)" Modern Age, vol. 17, no. 2 (Spring): 213-216.

Leonard, Thomas M., ed. 2005. Encyclopedia of the Developing World. Volume 1. A-E. New York: Psychology Press.

Levenson, Joseph R. 1962. "The Place of Confucius in Communist China.” The China Quarterly, no. 12: 1-18.

Lijphart, Arend. 1971. "Comparative Politics and the Comparative Method," The American Political Science Review, vol. 65, no.3: 682-93.

Linklater, Andrew, and Hidemi Suganami. 2006. The English School of International Relations: A Contemporary Reassessment. Cambridge: Cambridge University Press.

Lipscy, Phillip Y. 2015. "Who's Afraid of the AIIB? Why the United States Should Support China's Asian Infrastructure Investment Bank," Foreign Affairs, May 7; available online at https://www.foreignaffairs.com/articles/china/2015-05-07/whosafraid-aiib.

Lobell, Steven E. 2003. The Challenge of Hegemony: grand strategy, trade, and domestic politics. Ann Arbor: The University of Michigan Press.

Lobell, Steven E., Norrin M. Ripsman, and Jeffrey W. Taliaferro. 2009. Neoclassical Realism, the State, and Foreign Policy. Cambridge: Cambridge University Press.

Luttwak, Edward N. 2012. The Rise of China vs. the Logic of Strategy. Cambridge, MA \& London: The Belknap Press of Harvard University Press.

Lynch, Daniel C. 2015. China's Futures: PRC elites debate economics, politics, and foreign policy. Stanford, CA: Stanford University Press.

Ma, Damien. 2012. "China Digs It: How Beijing Cornered the Rare Earths Market," Foreign Affairs.com, April 25; available online at http://www.foreignaffairs.com/articles/137602/damien-ma/china-digs-it.

Mahnken, Thomas G., ed. 2012. Competitive Strategies for the $21{ }^{\text {st }}$ Century: theory, history, and practice. Stanford: Stanford University Press.

Malik, Mohan. 2011. China and India: great power rivals. Boulder, CO: First Forum Press. 
Marcus, George E. 2003. "The Psychology of Emotion and Politics," in Oxford Handbook of Political Psychology. David O. Sears, Leonie Huddy, and Robert Jervis, eds. New York: Oxford University Press.

Mao Zedong. 1967 [1937]. On Contradiction. Beijing: Foreign Language Press.

Mearsheimer, John J. 2003. The Tragedy of Great Power Politics. New York: W.W. Norton \& Company.

Morgenthau, Hans Joachim. 1948. Politics among Nations: the struggle for power and peace. New York: Alfred A. Knopf.

Morrison, Wayne M. and Rachel Tang. 2012. China's Rare Earth Industry and Export Regime: economic and trade implications for the United States. Washington, D.C.: Congressional Research Service Report published by the Federation of American Scientists (FAS), April 30; available online at http://www.fas.org/sgp/crs/row/R42510.pdf.

Nathan, Andrew J., and Andrew Scobell. 2013. China's Search for Security. New York: Columbia University Press. and 2012. "How China Sees America: the sum of Beijing's Fears," Foreign Affairs, vol. 91, no. 5 (September/October), pp. 32-47. 2011. "What China Wants: bargaining with Beijing," Foreign Affairs, vol. 90, no. 4 (July/August), pp. 153-158.

and Robert S. Ross. 1997. The Great Wall and the Empty Fortress: China's search for security. New York: W. W. Norton \& Co.

Navari, Cornelia, and Daniel Green, eds. 2013. Guide to the English School in International Studies. West Sussex: John Wiley \& Sons.

Nolan, Peter. 2012. Is China Buying the World? Cambridge, UK \& Malden, Mass.: Polity Press.

Norrlof, Carla, and Simon Reich. 2015. "American and Chinese leadership during the global financial crisis: Testing Kindleberger's stabilization functions," International Area Studies Review (March 19), pp. 1-24; available online at http://ias.sagepub.com/cgi/rapidpdf/2233865915573638v1.

Nye, Jr., Joseph S. 2011. The Future of Power. New York: PublicAffairs. 
Odgaard, Liselotte. 2012. China and Coexistence: Beijing's national security strategy for the twenty-first century. Atlanta \& Baltimore: Woodrow Wilson Center Press \& Johns Hopkins University Press.

Pant, Harsh V. 2011. China's Rising Global Profile: the great power tradition. Brighton, UK: Sussex Academic Press.

Papasotiriou, Charalambos "Harry." 1992. Byzantine Grand Strategy. Unpublished Dissertation. Stanford, CA: Department of Political Science, Stanford University.

Pillsbury, Michael. 2015. The Hundred-Year Marathon: China's secret strategy to replace America as the global superpower. New York: Henry Holt and Company.

$\mathrm{Pu}$ Xiaoyu. 2012. Limited Rebranding: status signaling, multiple audiences, and the incoherence of China's grand strategy. Unpublished Dissertation. Columbus, OH: Graduate Program in Political Science, Ohio State University.

Qin Yaqing. 2014. "Continuity and Change: background knowledge and China's international strategy," The Chinese Journal of International Politics, vol. 7, no. 3, pp. 285-314.

Qing, Jiang. 2013. A Confucian Constitutional Order: how China's ancient past can shape its potlitical future. Daniel A. Bell, and Ruiping Fan, eds. Edmund Ryden, transl. Princeton, NJ: Princeton University Press.

Reeves, Jeffrey. 2015. China's Foreign Relations with Weak Peripheral States: Asymmetrical Economic Power and Insecurity. Abingdon, UK: Routledge.

Richardson, Courtney J. 2012. The Chinese Mirror has Two Faces? Understanding China's United Nations Peacekeeping Participation. Unpublished Dissertation. Boston: Fletcher School of Law and Diplomacy, Tufts University.

Rosecrance, Richard, ed. 2001. The New Great Power Coalition. Lanham, MD: Rowman \& Littlefield Publishers.

Rosenau, James N. 1968. "The National Interest," in International Encyclopedia of the Social Sciences. D. L. Sills, ed. New York: Macmillan and The Free Press, pp. 34-40.

Ross, Robert S., and Zhu Feng. 2008. China's Ascent: power, security, and the future of international politics. Ithaca, NY: Cornell University Press.

Roy, Denny. 2014. "China's Grand Strategy is not Absent, Just Contradictory." Asia Pacific Bulletin, No. 292 (December 3). Available online at: http://www.eastwestcenter.org/sites/default/files/private/apb292.pdf. 
2013. The Return of the Dragon: rising China and regional security. New York: Columbia University Press.

Saha, Subrata. 2013. China's Grand Strategy from Confucius to Contemporary. Washington, DC: BiblioGov.

Salidjanova, Nargiza, and Iacob Koch-Weser. 2014. "China's 2014 Government Work Report: Taking Stock of Reforms," U.S.-China Economic and Security Review Commission Staff Research Backgrounder, April 1; available online at http://www.uscc.gov/sites/default/files/Research/USCC\%20Backgrounder_NPC\%20s corecard.pdf.

Saunders, Phillip Charles. 2006. China's Global Activism: strategy, drivers, and tools. Washington, D.C.: National Defense University Press.

Scheipers, Sibylle. 2010. Negotiating Sovereignty and Human Rights: International Society and the International Criminal Court. Manchester: Manchester University Press.

Serruys, Harry. 1960. "Four Documents Relating to the Sino-Mongol Peace of 1570-1571." Monumenta Serica 19: 1-66.

Shambaugh, David. 2013. China Goes Global: the partial power. Oxford: Oxford University Press.

Rowman \& Littlefield Publishers.

challenges. Abingdon, UK: Routledge.

Shen, Simon. 2012. "Introduction: Multidimensional Diplomacy as a Global Phenomenon," in Multidimensional Diplomacy of Contemporary China. Simon Shen, and Jean-Marc F. Blanchard, eds. Lanham, MD: Lexington Books.

Shenkman, Rick. 2016. Political Animals: how our stone age brain gets in the way of smart politics. New York: Basic Books.

Shi, Yinhong. 2001. "The Rising China: essential disposition, secular grand strategy, and current prime problems;" available online at http://www.spfusa.org/Program/av2001/feb1202.pdf. 
Shih Chih-yu, and Huang Chiung-chiu. 2015. "China's Quest for Grand Strategy: Power, National Interest, or Relational Security?" Chinese Journal of International Politics, vol. 8, no. 1 (Spring), pp. 1-26.

Shih Chih-yu. 2012. "From Sinic World to Multiple International Relations in East Asia: Between Outsider Japan and Insider Korea." Tamkang Journal of International Affairs 15, no. 3, pp. 1-38.

Smith, Jeff M. 2015a. "Beware China's Grand Strategy." Foreign Affairs (May 20). Available online at https://www.foreignaffairs.com/articles/china/2015-05-20/bewarechinas-grand-strategy.

Smith, Sheila A. 2015b. Intimate Rivals: Japanese domestic politics and a rising China. New York: Columbia University Press.

Smith, P. J. 2013. "The Senkaku/Diaoyu Island Controversy: a crisis postponed," Naval War College Review 66, no. 2, pp. 27-44.

Steinberg, James, and Michael E. O'Hanlon. 2014. Strategic Reassurance and Resolve: U.S.-China Relations in the Twenty-First Century. Princeton: Princeton University Press.

Steinfeld, Edward S. 2010. Playing Our Game: why China's rise doesn't threaten the West. Oxford: Oxford University Press.

Summers, Tim. 2015. "What exactly is 'one belt, one road'?" The World Today 71, no. 5, pp. ; available online at https://www.chathamhouse.org/publication/twt/what-exactlyone-belt-one-road.

Suzuki, Shogo. 2009. Civilization and Empire: China and Japan's Encounter with the European International Society. London: Taylor and Francis.

Swaine, Michael D. 2015. "Xi Jinping's Address to the Central Conference on Work Relating to Foreign Affairs: Assessing and Advancing Major Power Diplomacy with Chinese Characteristics," China Leadership Monitor (Hoover Institution), no. 46 (Winter); available online at http://www.hoover.org/sites/default/files/clm46ms.pdf.

, Sara A. Daly, Peter W. Greenwood, eds. 2000. Interpreting China's Grand Strategy: past, present, and future. Santa Monica, CA: RAND Corporation.

Taliaferro, Jeffrey W., Norrin M. Ripsman, Steven E. Lobell, eds. 2013. The Challenge of Grand Strategy: the great powers and the broken balance between the World Wars. Cambridge: Cambridge University Press. 
Taylor, Brendan. 2010. Sanctions as Grand Strategy. Abingdon, UK: Routledge.

Taylor and Francis. 2015. "Chinese Foreign Relations with Weak Peripheral States: Asymmetrical Economic Power and Insecurity," Taylor and Francis/Routledge, October 25; available online at http://www.tandf.net/books/details/9781138891500/.

Teufel Dryer, June. 2012. China's Political System: Modernization and Tradition. $8^{\text {th }}$ edition. New York: Pearson.

The Economist Intelligence Unit. 2015. "Prospects and challenges on China's 'one belt, one road': a risk assessment report," The Economist Intelligence Unit; available online at http://www.eiu.com/public/topical_report.aspx?campaignid=OneBeltOneRoad.

Thucydides. 2009. The Peloponnesian War, Martin Hammond (transl.), P.J. Rhodes (introduction and notes). Oxford, U.K.: Oxford University Press.

Twitchett, Dennis C., and John K. Fairbank, eds. 1978. The Cambridge History of China. Cambridge, U.K.: Cambridge University Press

Van Evera, Stephen. 1997. Guide to Methods for Students of Political Science. Ithaca, NY: Cornell University Press.

Waltz, Kenneth N. 2010 [1979]. Theory of International Politics. New York: Waveland Press.

Wang Hung-jen. 2013. The Rise of China and Chinese International Relations Scholarship. Lanham, MD: Lexington Books.

Wang Jianwei, and Chen Dingding. 2012. "China's New Grand Strategy in Call: Selective Leadership," Paper presented at the International Conference on China's Grand Strategy and Diplomatic Transformation at the University of Macau, February 3, 2012.

Wang Jisi. 2011. "China's Search for a Grand Strategy - A Rising Great Power Finds its Way," Foreign Affairs, vol. 90, no. 2 (March/April), pp. 68-79.

Wang Yi. 2016. "Remembering Imperialism and Anti-Imperialism: Collective Memory of International History in Socialist China," Paper presented at the $57^{\text {th }}$ Annual Convention of the International Studies Association, Atlanta, Georgia, March 19, 2016.

Wang Zheng. 2012. Never Forget National Humiliation: Historical Memory in Chinese Politics and Foreign Relations. New York: Columbia University Press. 
. 2008. "National Humiliation, History Education, and the Politics of Historical Memory: Patriotic Education Campaign in China," International Studies Quarterly, vol. 52, pp. 783-806.

Weggel, Oskar. 1997. China im Aufbruch: Konfuzianismus und politische Zukunft [Awakening China: Confucianism and political future]. Munich: Beck.

Yan Xuetong. 2014. "From Keeping a Low Profile to Striving for Achievement," The Chinese Journal of International Politics, vol. 7, no. 2, pp. 153-184.

2011. Ancient Chinese Thought, Modern Chinese Power. Daniel A. Bell, and Sun Zhe, eds. Edmund Ryden, transl. Princeton, NJ: Princeton University Press.

Yao Xinzhong. 2000. An Introduction to Confucianism. Cambridge: Cambridge University Press.

Ye Shulan. 2010. Rising China's Regional Policy in East Asia: a constructivist perspective. Unpublished dissertation. Hong Kong: Hong Kong Baptist University.

Ye Zicheng. 2011. Inside China's Grand Strategy: the perspective from the People's Republic. Steven I. Levine, and Liu Guoli, eds., and transl. Lexington: The University of Press of Kentucky.

Yetiv, Steve A. 2008. The Absence of Grand Strategy: the United States in the Persian Gulf, 1972-2005. Baltimore: Johns Hopkins University Press.

Yu, Dan. 2009. Confucius From the Heart: ancient wisdom for today's world. Esther Tyldesley, transl. New York: Simon and Schuster.

Yun, Peter I. 1998. Rethinking the Tribute System: Korean States and Northeast Asian Interstate Relations, 600-1600. Los Angeles, Cali.: PhD Dissertation, University of California, L.A.

Zhao Suisheng, ed. 2004. Chinese Foreign Policy: pragmatism and strategic behavior. Armonk, NY: M.E. Sharpe.

Zheng Bijian. 2005. "China's 'Peaceful Rise' to Great-Power Status," Foreign Affairs, vol. 84, no. 5 (September/October), pp. 18-24.

Zhou, Jinghao. 2003. Remaking China's Public Philosophy for the Twenty-First Century. Westport, CT: Praeger Publishers.

Zhu Zhiqun. 2013. "Foreign Policy of the People's Republic of China," in Foreign Policy in Comparative Perspective: Domestic and International Influences on State Behavior, 
Second Edition. Ryan K. Beasley, Juliet Kaarbo, Jeffrey S. Lantis, and Michael T. Snarr, eds. Thousand Oaks, Cali.: CQ Press.

peace. Abingdon, UK: Routledge.

\section{News Articles}

AFP. 2010. "China blocked exports of rare earth metals to Japan, traders claim," The Telegraph, September 24; available online at http://www.telegraph.co.uk/finance/china-business/8022484/China-blocked-exportsof-rare-earth-metals-to-Japan-traders-claim.html.

Ashraf, Sajjad. 2015. "AIIB - the Beginning of Economic Challenge to the U.S." China U.S. Focus, July 14; available online at http://www.chinausfocus.com/financeeconomy/aiib-the-beginning-of-economic-challenge-to-the-u-s/.

BBC News. 2010a. "Japan laments China protest damage," BBC News, October 18; available online at http://www.bbc.com/news/world-asia-pacific-11562973.

BBC News. 2010b. "China resumes rare earth exports to Japan," BBC News, November 24; available online at http://www.bbc.com/news/business-11826870.

Bloomberg. 2010. "China cuts export quotas for rare earths by 35\%." Bloomberg, December 28; available online at http://www.bloomberg.com/news/articles/2010-1228/china-cuts-first-round-rare-earth-export-quotas-by-11-correct- .

Boren, Zachary Davies. 2015. "Ukraine crisis: Top Chinese diplomat backs Putin and says West should 'abandon zero-sum mentality," The Independent, February 27; available online at http://www.independent.co.uk/news/world/europe/ukraine-crisis-topchinese-diplomat-backs-putin-says-west-should-abandon-zerosum-mentality10075762.html.

Brown, James D. J. 2015. "Ukraine and the Russia-China Axis: Current U.S. policy on the Ukraine crisis is driving Russia into China's embrace," The Diplomat, April 2; available online at http://thediplomat.com/2015/04/ukraine-and-the-russia-china-axis.

Brown, Kerry. 2014. "Is China's Money Enough to Unite Central and Eastern Europe? China seeks political support through new diplomatic groups. But often its 'partners' 
are only interested in handouts," The Diplomat, October 14; available online at http://thediplomat.com/2014/10/is-chinas-money-enough-to-unite-central-andeastern-europe.

Chan, Minnie. 2014. "China's growing peacekeeping commitment to UN shows shift in foreign policy," South China Morning Post, May 30; available online at http://www.scmp.com/news/china/article/1521454/chinas-growing-peacekeepingcommitment-un-shows-shift-foreign-policy.

Chang, Gordon G. 2010. "China's New Economic Warfare," Forbes, September 24; available online at http://www.forbes.com/sites/gordonchang/2010/09/24/chinas-neweconomic-warfare/.

Cheung, Francis, and Alexious Lee. 2015. "A Brilliant Plan: One Belt, One Road." CLSA, December 22; available online at https://www.clsa.com/special/onebeltoneroad/.

Chin, Curtis S. 2015. "Beyond the AIIB Signing Ceremony," China U.S. Focus, July 7; available online at http://www.chinausfocus.com/finance-economy/beyond-thesigning-ceremony-at-a-chinas-own-asian-development-bank/.

China FTA Network. 2014. "Zhongguo-Dongmeng qiaoding 'Yidai, Yilu' da dan” (China and ASEAN Have Agreed on the General Outline of 'One Belt, One Road'), China FTA Network, December 3; available online at http://fta.mofcom.gov.cn/article/shidianyi/201412/19256_1.html.

CNN. 2012. "Obama Announces WTO Case Against China Over Rare Earths." CNN.com, March 13; available online at http://www.cnn.com/2012/03/13/world/asia/china-rareearths-case/.

Cooper, Joseph, Bonnie Berman, Richard Ives, and Paul Leary. 2016. How Our Stone-Age Brain Gets in the Way of Smart Politics, WLRN.org, March 2; available online at http:// wlrn.org/post/how-our-stone-age-brain-gets-way-smart-politics.

Delfs, Arne, and Patrick Donahue. 2015. "Merkel Seeks China's Support on Refugees as Crisis Follows Her," Bloomberg Business, October 29; available online at http://www.bloomberg.com/news/articles/2015-10-29/merkel-seeks-china-s-supporton-refugees-as-crisis-follows-her.

Economist, The. 2015a. "The New Game: American dominance is being challenged," The Economist, October 17; available online at http://www.economist.com/news/leaders/21674699-american-dominance-being- 
challenged-new-

game?vh=3248c69bc71e9e136fbd9db77e8fa5819f94b496\&ts=1445093492. online at http://www.economist.com/news/china/21650566-crisis-ukraine-drawingrussia-closer-china-relationship-far-equal.

2015c. "Xi's History Lessons: The Communist Party Is Plundering History to Justify Its Present-Day Ambitions," The Economist, August 15; available online at http://www.economist.com/news/leaders/21660977-communist-partyplundering-history-justify-its-present-day-ambitions-xishistory?vh=1ab4993e1be25c52c62b4a38b317531d494f0ba7\&ts=1439923983.

2014. "What China Wants," The Economist; available online at http://www.economist.com/news/essays/21609649-china-becomes-again-worldslargest-economy-it-wants-respect-it-enjoyed-centuries-past-it-does-not.

Fackler, Martin., and Ian Johnson. 2010. "Japan Retreats with Release of Chinese Boat Captain," The New York Times, September 24; available online at http://www.nytimes.com/2010/09/25/world/asia/25chinajapan.html?pagewanted=all\& _r $=0$.

Feffer, John. 2015. "The European Union May Be on the Verge of Collapse," The Nation, January 27; available online at http://www.thenation.com/article/196193/europeanunion-may-be-verge-collapse.

Fioretti, Julia. 2015. "EU looks to China to invest in its telecoms sector," Reuters, February 5; available online at http://uk.reuters.com/article/2015/02/05/uk-eu-chinatelecommunications-idUKKBNOL922S20150205.

Gorst, Isabel. 2014. "China Winning from Russia-Ukraine Crisis," Financial Times, September 1; available online at http://blogs.ft.com/beyond-brics/2014/09/01/chinaemerges-as-winner-from-russia-ukraine-crisis.

He, Amy. 2015. "US, China expected to lead on climate talks," China Daily USA, January 28; available online at http://usa.chinadaily.com.cn/us/201501/28/content_19424216.htm.

He, Yafei. 2015b. "Connecting the World Through 'Belt \& Road," China U.S. Focus, October 13; available online at http://www.chinausfocus.com/foreign-policy/the-beltroad-initiative-offers-new-model-of-cooperation-in-global-governance/. 
2015c. "Why China's Belt and Road Plan Is the Best Way to Lift the Global Economy," The World Post, October 21; available online at http://www.huffingtonpost.com/he-yafei/china-road-belt-global-

economy_b_8338916.html.

Henry, Stephanie. 2012. 'IMF Changes Stance on RMB - Now 'Moderately Undervalued'; WTO Again Cites US for 'Zeroing' Practice in US-China Case over Antidumping Tariffs," The US-China Business Council; available online at https://www.uschina.org/washington-update/imf-changes-stance-rmb-nowmoderately-undervalued-wto-again-cites-us-zeroing.

Hofman, Bert. 2015. "China One Belt One Road Initiative: What we know thus far," The World Bank, December 4; available online at http://blogs.worldbank.org/eastasiapacific/china-one-belt-one-road-initiative-whatwe-know-thus-far.

Hornby, Lucy. 2015. “China's 'One Belt One Road' plan greeted with caution,” Financial Times, November 20; available online at http://www.ft.com/cms/s/2/5c022b50-78b711e5-933d-efcdc3c11c89.html\#axzz3uw9LTDKN.

Inoue, Yuko. 2010. "China lifts rare earth export ban to Japan: trader," Reuters, September 29; available online at http://www.reuters.com/article/2010/09/29/us-japan-chinaexport-idUSTRE68S0BT20100929.

Isachenkov, Vladimir. 2006. "China, Russia Sign Friendship Agreement,” absNEWS, July 16; available online at http://abcnews.go.com/International/story?id=80779.

Jiji. 2013. "Curtailed access to China's diplomatic archives fuels Senkaku conjecture," The Japan Times, February 1; available online at http://www.japantimes.co.jp/news/2013/02/01/national/curtailed-access-to-chinasdiplomatic-archives-fuels-senkaku-conjecture/\#.UyeOflea_DI

Keck, Zachary. 2014. "China's Drafting a South China Sea ADIZ," The Diplomat, January 31; available online at http://thediplomat.com/2014/01/chinas-drafting-a-south-chinasea-adiz/.

Kennedy, Scott, and David A. Parker. 2015. "Building China's 'One Belt, One Road,'” CSIS - Center for Strategic \& International Studies, April 3; available online at http://csis.org/publication/building-chinas-one-belt-one-road. 
Kundnani, Hans. 2015. "The 'strategic' case for TTIP," European Council on Foreign Relations, $\quad$ February $9 ; \quad$ available online at http://www.ecfr.eu/article/commentary_the_strategic_case_for_ttip421.

Kyodo. 2012. "China losing rare-earth diplomatic leverage over Japan; exports hit lowest level in 10 years," Japan Times, October 25; available online at http://www.japantimes.co.jp/news/2012/10/25/business/china-losing-rare-earthdiplomatic-leverage-over-japan-exports-hit-lowest-level-in-10-years/\#.VehyyJd81Gl.

Lukyanov, Fyodor. 2015. "China Will Win the War Over Ukraine," Russia Beyond the Headlines, March 19; available online at http://rbth.com/opinion/2015/03/19/china_will_win_the_war_over_ukraine_44623.ht $\mathrm{ml}$.

Lynch, Colum. 2015. "At the U.N., Beijing Begins to Shift Away From Putin," Foreign Policy, October 21; available online at http://foreignpolicy.com/2015/10/21/at-the-u-nbeijing-begins-to-shift-away-from-putin/.

Moore, Malcolm. 2010. "China warns tourists not to visit Japan," The Telegraph, October 1; available online at http://www.telegraph.co.uk/news/worldnews/asia/china/8036058/China-warnstourists-not-to-visit-Japan.html.

Nye, Jr., Joseph S. 2015a. “A new Sino-Russian alliance?” Azer News, January 15; available online at http://www.azernews.az/analysis/75903.html.

. 2015b. "Don't expect a Sino-Russian alliance to challenge the West" Daily Star, January 24; available online at http://www.dailystar.com.lb/Opinion/Commentary/2015/Jan-24/285146-dont-expecta-sino-russian-alliance-to-challenge-the-west.ashx.

Online, YaleGlobal. 2015. "Economic Interests Attract China to Russia, Not Edgy Policies - Analysis," Eurasia Review News \& Analysis, February 4; available online at http://www.eurasiareview.com/04022015-economic-interests-attract-china-russia-notedgy-policies-analysis.

Ou Xiaoli. 2015. "Laying the foundations for China's 'One Belt, One Road,"” South China Morning Post, November 25; available online at http://www.scmp.com/comment/insight-opinion/article/1882600/laying-foundationschinas-one-belt-one-road. 
People's Daily. 2014. "Xi Jinping ti zhanlue gouxiang: 'yi dai, yi lu' dakai 'zhumeng kongjian'” (Xi Jinping Advances a Strategic Concept: The 'One Belt, One Road' Gives Us Space to Build Dreams'), People's Daily, August 11; http://politics.people.com.cn/n/2014/0811/c1001-25439028.html.

Piasecki, Jakub, and Matt Olchawa. 2015. "Want to Save Ukraine? Forget Europe, Look to China," The Diplomat, July 26; available online at http://thediplomat.com/2015/07/want-to-save-ukraine-forget-europe-look-to-china/.

Pilling, David. 2010. "Keeping Its Distance," Financial Times, February 11; available online at http://www.ft.com/intl/cms/s/0/77a928a0-1511-11df-ad5800144feab49a.html\#axzz3noKp8ej8.

Pruzin, Daniel. 2014. "WTO Rules Against China On Rare Earths Export Restrictions," Bloomberg BNA, March 28; available online at http://www.bna.com/wto-rules-againstn17179889210.

Ramani, Samuel. 2015. "Hey, Putin, have you seen how much China is investing in Ukraine?" The Washington Post, July 24; available online at https://www.washingtonpost.com/blogs/monkey-cage/wp/2015/07/24/hey-putinhave-you-seen-how-much-china-is-investing-in-ukraine/.

RT Business. 2015. "China calls for Ukraine dialogue instead of sanctions against Russia," $R T$ Business, December 22; available online at https://www.rt.com/business/326756china-sanctions-europe-russia/.

Rudolf, Moritz. 2015. “China's 'Silk Road' Initiative Is at Risk of Failure,” The Diplomat, September 24; available online at http://thediplomat.com/2015/09/chinas-silk-roadinitiative-is-at-risk-of-failure/.

Rukomeda, Roman. 2015. "Changes brewing at 'Ukraine-China border," Unian, October 12; available online at http://www.unian.info/economics/1208235-changes-brewingat-ukraine-china-border.html.

Sano, Junya. 2015. "POINT OF VIEW: China goes on 'One Belt, One Road' initiative," The Asahi Shimbun, October 6; available online at http://ajw.asahi.com/article/views/opinion/AJ201510060014.

Shimbun, Y. 2014. "Japan-China COLD WAR 6 / After policy shift, China puts 'core interests' to forefront," The Japan News, March 19; available online at http://the-japannews.com/news/article/0001039151. 
Sieren, Frank. 2015. "Sieren's China: Ukraine is China's breadbasket," Deutsche Welle, August 1; available online at http://dw.com/p/1G8Fo.

Stringer, David. 2015. "China Export Tax Decision to Boost Rare Earth Demand, Lynas Says," Bloomberg.com, April 24; available online at http://www.bloomberg.com/news/articles/2015-04-24/china-export-tax-decision-toboost-rare-earth-demand-lynas-says.

Studies, Arnold A. Saltzman Institute of War and Peace. 2016. "Robert M. Scher, 'What's Old is New Again: Recasting the Department of Defense for Great Power Competition," Columbia University, School of International and Public Affairs; available online at https://sipa.columbia.edu/70/events/robert-m-scher-assistantsecretary-of-defense-for-strategy-plans-and-capabilities-whats-old-is-new.

Sun Yi. 2015. "Interview: Chinese diplomat calls powers' game root cause of Ukraine crisis," Xinhuanet.com, February 27; available online at http://news.xinhuanet.com/english/2015-02/27/c_134021440.htm.

Takahashi, K. 2014. "Shinzo Abe's Nationalist Strategy," The Diplomat, February 13; available online at http://thediplomat.com/2014/02/shinzo-abes-nationalist-strategy.

Takenaka, K. and Kaneko, K. 2012. "Japan fires water cannon to turn away Taiwan boats." Reuters, September 25; accessed at http://www.reuters.com/article/2012/09/25/uschina-japan-taiwan-idUSBRE88O02C20120925.

Tiezzi, Shannon. 2014a. "The EU and Russia: China's Balancing Act: in the EU, China finds an economic partner; in Russia, a strategic ally. How does Beijing balance the two?" The Diplomat, October 15; available online at http://thediplomat.com/2014/10/the-eu-and-russia-chinas-balancing-act.

. 2014b. "China Backs Russia on Ukraine: despite its principle of noninterference, domestic and international interests have Beijing siding with Moscow," The Diplomat, March 4; available online at http://thediplomat.com/2014/03/chinabacks-russia-on-ukraine.

2014c. "China Sets Economic Reform Targets for 2015," The Diplomat, December 12; available online at http://thediplomat.com/2014/12/china-setseconomic-reform-targets-for-2015/.

Collision," The Diplomat, February 14; available online at
The 14 d


http://thediplomat.com/2014/02/japan-seeks-chinese-compensation-over-2010-boatcollision-incident/.

Toktomushev, Kemel. 2015. "Chinese Neighbourhood Diplomacy: Afghanistan, Xinjiang and Central Asia," China U.S. Focus, July 14; available online at http://www.chinausfocus.com/foreign-policy/chinese-neighbourhood-diplomacyafghanistan-xinjiang-and-central-asia/.

UNIAN. 2015. "China becomes largest consumer of Ukrainian food," Ukraine Today, September 25; available online at http://uatoday.tv/news/china-becomes-largestconsumer-of-ukrainian-food-500608.html.

Viehe, Ariella, Aarthi Gunasekaran, and Hanna Downing. 2015. "Understanding China's Belt and Road Initiative," Center for American Progress, September 22; available online https://www.americanprogress.org/issues/security/report/2015/09/22/121628/understa nding-chinas-belt-and-road-initiative/.

Wang Weihua. 2015. "Hangshi jingji zoulang jianshe, zhu tui 'yi dai, yi lu' zhanlue" (Building Economic Corridors Will Help Push 'One Belt, One Road' Forward), Shanghai Institute for International Studies, April 17; available online at http://www.siis.org.cn/index.php?m=content $\& c=i n d e x \& a=$ show $\&$ catid $=22 \& i d=631$.

Wang Yiwei. 2015. "Neighbors, US equally important for China," Global Times, February 8; available online at http://www.globaltimes.cn/content/906620.shtml.

Wang, Z. 2010. "Collision video 'changes nothing," Global Times, November 8; available online at http://china.globaltimes.cn/diplomacy/2010-11/590070.html.

Wesolowsky, Tony. 2015. "Cultivating Ties: Ukraine Feeds China's Growing Appetite For Crops," Radio Free Europe, August 16; available online at http://www.rferl.org/content/china-ukraine-corn-agriculture-ties-russia/27191556.html.

Whitlock, C. 2012. "Panetta to Urge China and Japan to Tone Down Dispute over Islands," The Washington Post, September 9; available online at http://www.washingtonpost.com/world/national-security/panetta-to-urge-china-andjapan-to-tone-down-dispute-over-islands/2012/09/16/9b6832c0-fff3-11e1-b9167b5c8ce012c8_story.html.

Wong, Edward. 2015. "China Says It Could Set Up Air Defense Zone in South China Sea," The New York Times, May 31; available online at 
http://www.nytimes.com/2015/06/01/world/asia/china-says-it-could-set-up-airdefense-zone-in-south-china-sea.html?ref=world\&_r=1.

York 2014. "China Announces 12.2\% Increase in Military Budget," The New http://www.nytimes.com/2014/03/06/world/asia/china-military-budget.html.

van Ess, Hans. 2013. “China-Lexikon / Prof. Dr. Hans van Ess über Konfuzius und das Denken Chinas (Encyclopedia of China / Prof. Dr. Hans van Ess about Confucius and Chinese philosophy)," dctp.tv, March 16; available online at http://www.dctp.tv/filme/news-stories-17032013.

Xinhua. 2015. "Commentary: China-Switzerland FTA sets example for China-EU cooperation," global post: America's world news website, January 23; available online at http://www.globalpost.com/dispatch/news/xinhua-newsagency/150123/commentary-china-switzerland-fta-sets-example-china-eu-coope.

Xinhuanet.com, March 28; available online at http://news.xinhuanet.com/english/2015-03/28/c_134105435.htm.

2015c. "China, CEE countries sign memo to promote Belt and Road Initiative," Xinhuanet.com, November 27; available online at http://news.xinhuanet.com/english/2015-11/27/c_134859206.htm.

. 2015d. "China an active force in regional economic integration," Xinhuanet.com, November 19; available online at http://news.xinhuanet.com/english/2015-11/19/c_134834693.htm.

2015e. "Spotlight: China, ASEAN envision new prospects for cooperation under Belt and Road Initiative," Xinhuanet.com, November 24; available online at http://news.xinhuanet.com/english/2015-11/24/c_134848462.htm. . 2015f. "China Focus: Belt and Road to boost China-ASEAN economic ties," Xinhuanet.com, November 11; available online at http://news.xinhuanet.com/english/2015-11/11/c_134804820.htm.

2015g. "China welcomes neighbors to join 'Belt and Road' for common development," Xinhuanet.com, November 7; available online at http://news.xinhuanet.com/english/2015-11/07/c_134792749.htm. 
. 2015h. "Silk Road Forum 2015 opens in Madrid," Xinhuanet.com, October 29; available online at http://news.xinhuanet.com/english/photo/201510/29/c_134763578_2.htm.

. 2015i. "Denmark signs AIIB agreement," Xinhuanet.com, October 28; available online at http://news.xinhuanet.com/english/2015-10/28/c_134756186.htm.

. 2015j. "'One Belt, One Road'" and RMB internationalization serve global interest: Report," Xinhuanet.com, October 9; available online at http://news.xinhuanet.com/english/2015-10/09/c_134695173.htm.

. 2015k. "EU, China hold workshop to discuss 'New Silk Road' strategy," http://news.xinhuanet.com/english/2015-09/15/c_134623864.htm.

_. 20151. "China Focus: China sketches out priorities of 'Belt and Road' initiatives," Xinhuanet.com, February 1; available online at http://news.xinhuanet.com/english/china/2015-02/01/c_133962709.htm.

Xinhuanet.com, $2015 \mathrm{~m}$. "Full Text: Report on the Work of the Government,"
March
Xit http://news.xinhuanet.com/english/china/2015-03/16/c_134071473_2.htm.

. 2015n. "Chronology of Asian Infrastructure Investment Bank," China Daily, April 1; available online at http://www.chinadaily.com.cn/business/201504/01/content_19966945.htm.
- 2015o. "Chronology of Asian Infrastructure Investment Bank," Xinhuanet.com, December 25; available online at http://news.xinhuanet.com/english/2015-12/25/c_134952611.htm.
. 2014a. "Rare Earth Exports Jump 31\% in China in August," Want China Times, September 9; available online at http://www.wantchinatimes.com/news- subclass-cnt.aspx $\mathrm{id}=20140909000075 \& \mathrm{cid}=1203$.
. 2014b. "China dismisses ADIZ reports, optimistic about South China Sea," Xinhuanet.com, February 1; available online at http://news.xinhuanet.com/english/china/2014-02/02/c_126085456.htm.
development," Xinhuanet.com, November http://news.xinhuanet.com/english/china/2014-11/30/c_133822694.htm.


. 2014d. "Highlights: Chinese Premier Li Keqiang's Government Work Report," CCTV America \& Xinhua News Agency, March 5; available online at http://www.cctv-america.tv/2014/03/05/highlights-chinese-premier-li-keqiangsgovernment-work-report/.

- 2014e. "Xinhua Insight: China to keep 2015 growth, policy steady under 'new normal," Xinhuanet.com, December 11; available online at http://news.xinhuanet.com/english/china/2014-12/11/c_133848770.htm.

$\begin{array}{ll}\text { Xinhuanet.com, 2014f. "Full Text: Report on the Work of the Government," } & \text { March }\end{array}$ http://news.xinhuanet.com/english/special/2014-03/14/c_133187027.htm.

Yap Chun-Wei. 2015. "China Ends Rare-Earth Minerals Export Quotas," Wall Street Journal, January 5; available online at http://www.wsj.com/articles/china-ends-rareearth-minerals-export-quotas-1420441285.

Zhang Dan. 2015. "China won't emulate the 'Crimea pattern' in territorial issues," CCTV.com, February 9; available online at http://english.cntv.cn/2015/02/09/ARTI1423447332618758.shtml.

Zhen, Summer. 2015. "China's 'One Belt One Road' investment to reach US\$200 billion in three years," South China Morning Post, October 27; available online at http://www.scmp.com/business/global-economy/article/1872858/one-belt-one-roadinvestment-reach-us200b-three-years.

Zhu Zhiqun. 2015. "China's AIIB and OBOR: Ambitions and Challenges," The Diplomat, October 9; available online at http://thediplomat.com/2015/10/chinas-aiib-and-oborambitions-and-challenges. 


\section{APPENDIX}

\section{New Silk Roads | China is assembling new trade routes, binding other regions closer to it}

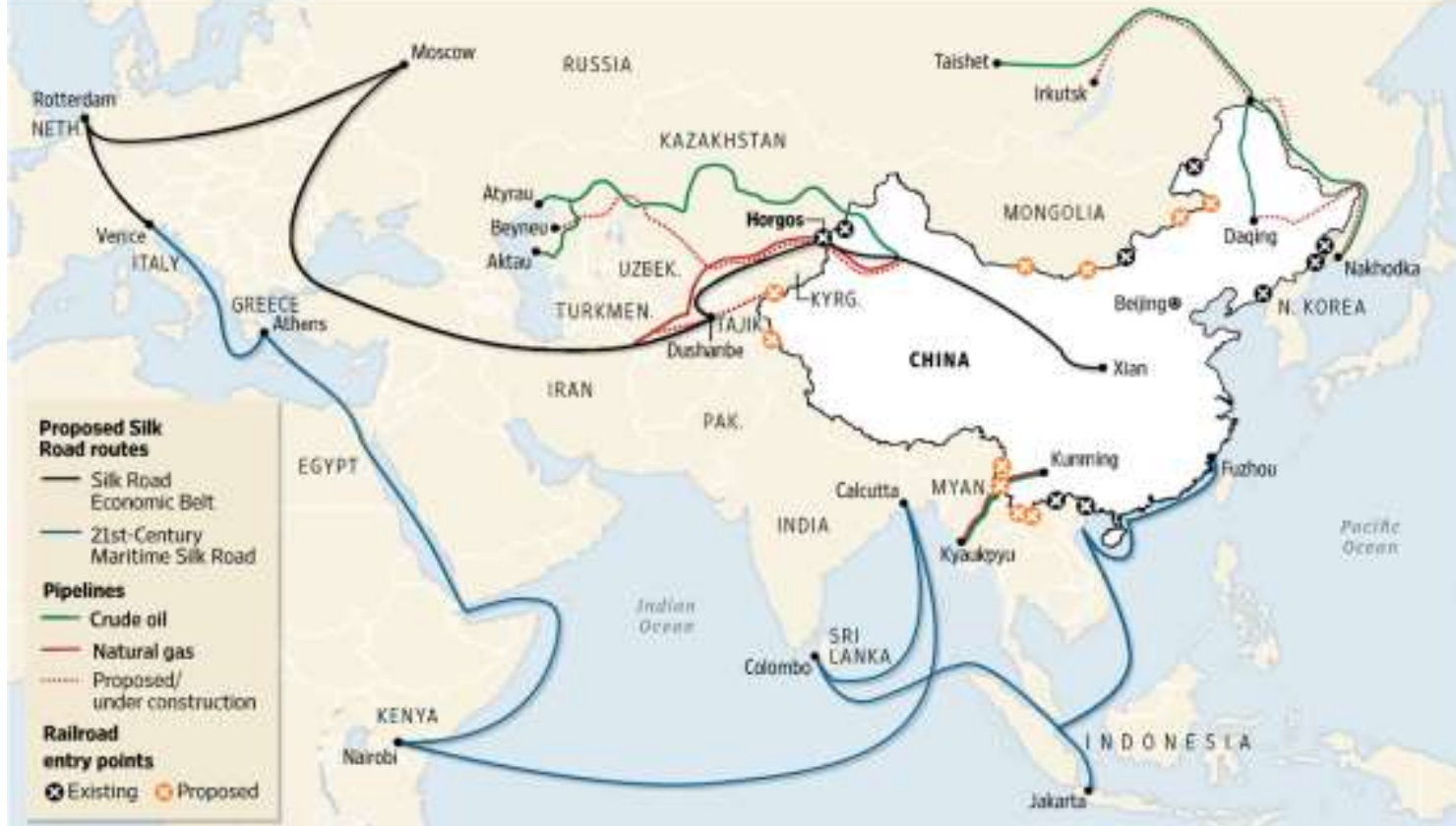

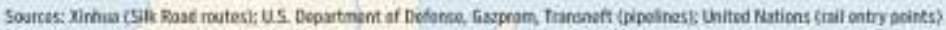

Illustration 1: Economic Belt and Maritime Silk Road for the Twenty-first Century (Source: The Wall Street Journal; available online at http://si.wsj.net/public/resources/images/P1BR865_CAPEC_16U_20141107194517.jpg). 


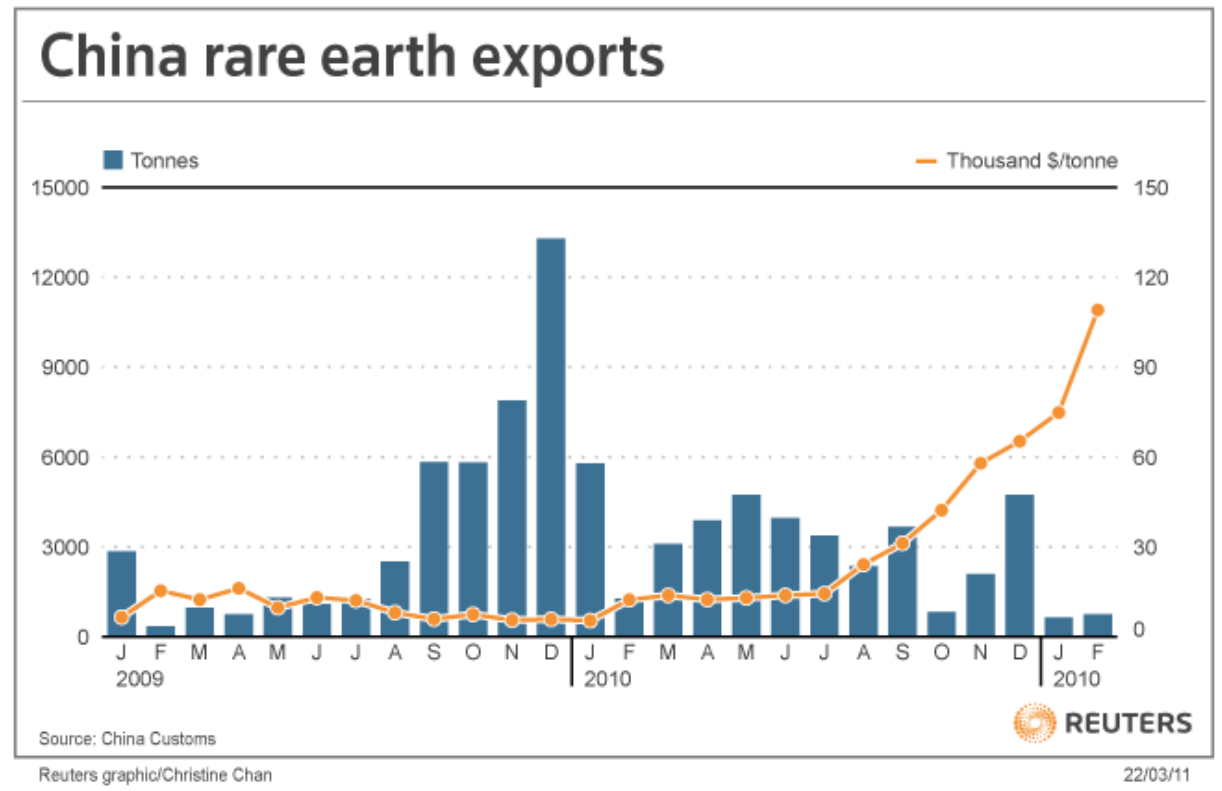

Illustration 2: China Rare Earth Exports \& Prices, 2009-2011 (Source: Reuters / China Customs; available online at http://graphics.thomsonreuters.com/11/03/CN_RREXP0311_CC.gif).

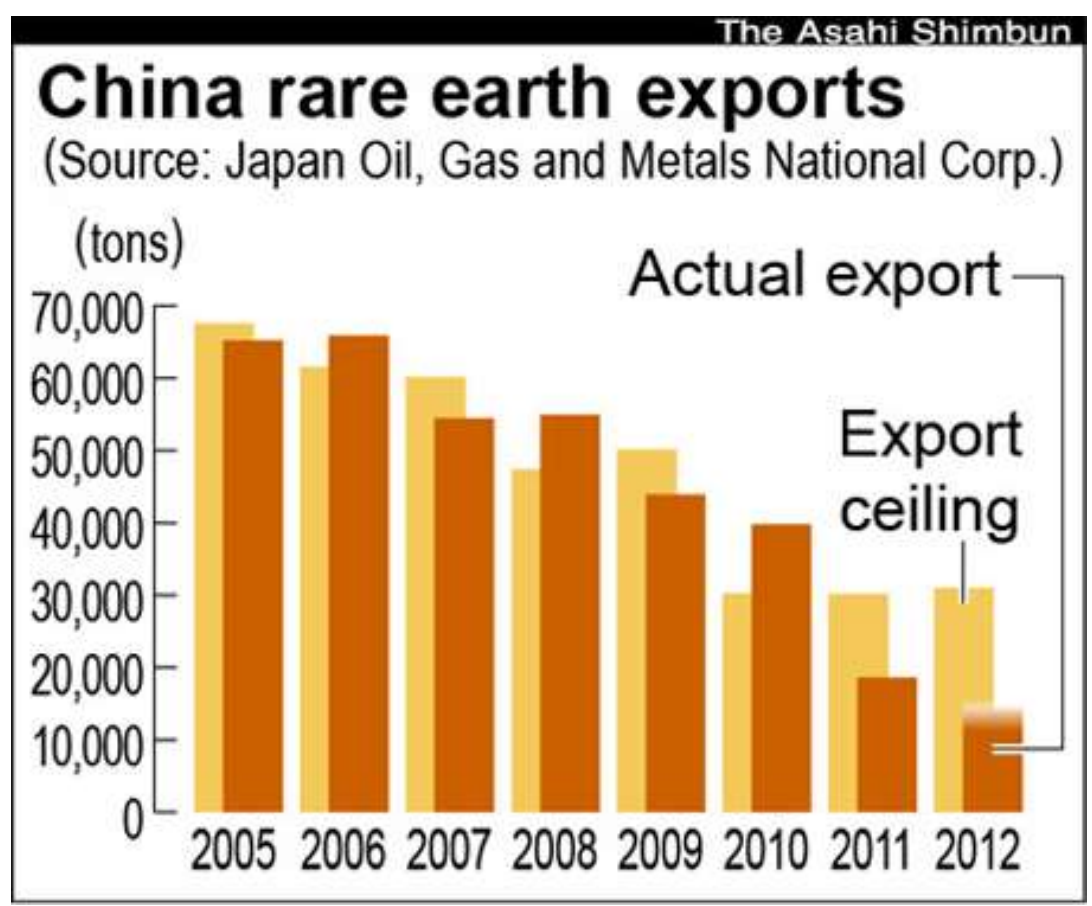

Illustration 3: China Rare Earth Exports \& Quotas (Source: The Asahi Shimbun / Japan Oil, Gas and Metals National Corp.; available online at http://ajw.asahi.com/article/asia/china/AJ201212290067). 


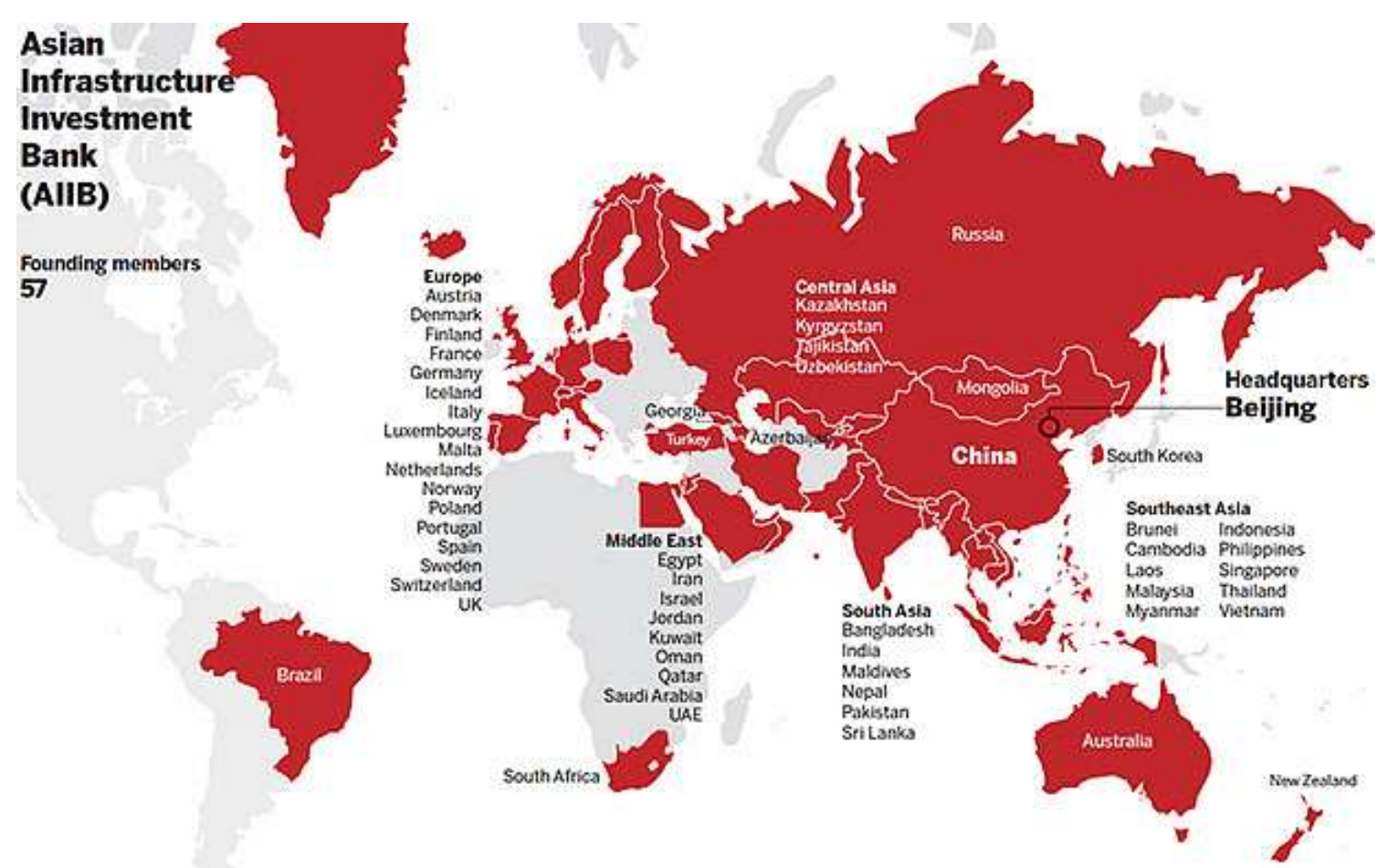

Illustration 4: Founding Members of the AIIB (Source: The Telegraph; available online at http://i.telegraph.co.uk/multimedia/archive/03281/china-watch-map_3281019b.jpg).

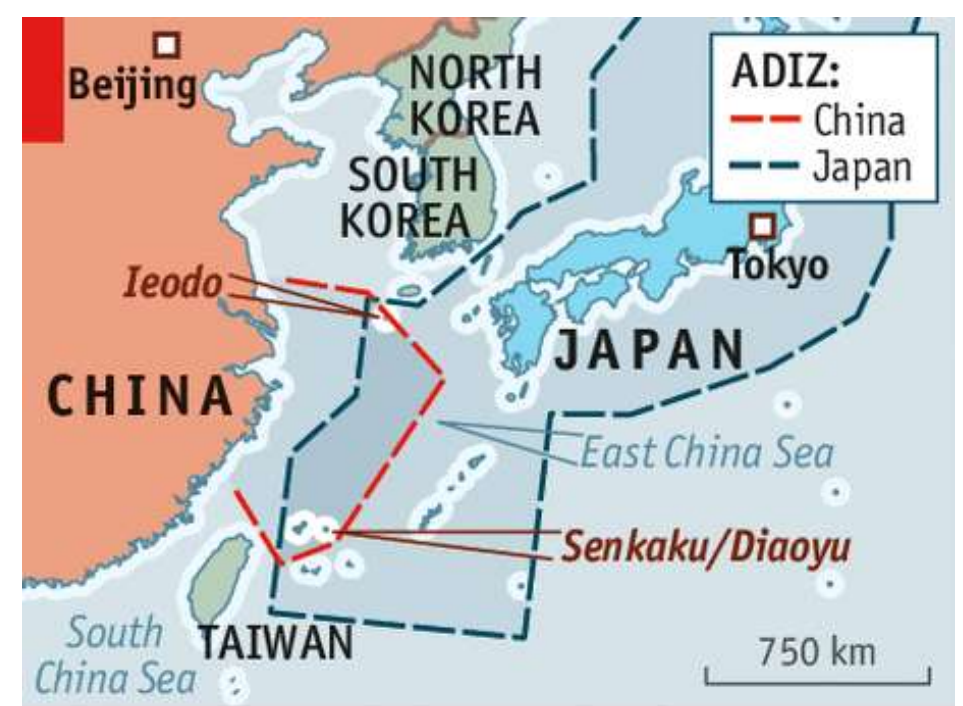

Illustration 5: China's ADIZ vs. Japan's ADIZ (Source: The Economist; available online at http://cdn.static-economist.com/sites/default/files/images/2013/11/articles/main/20131130_ldm222.png). 


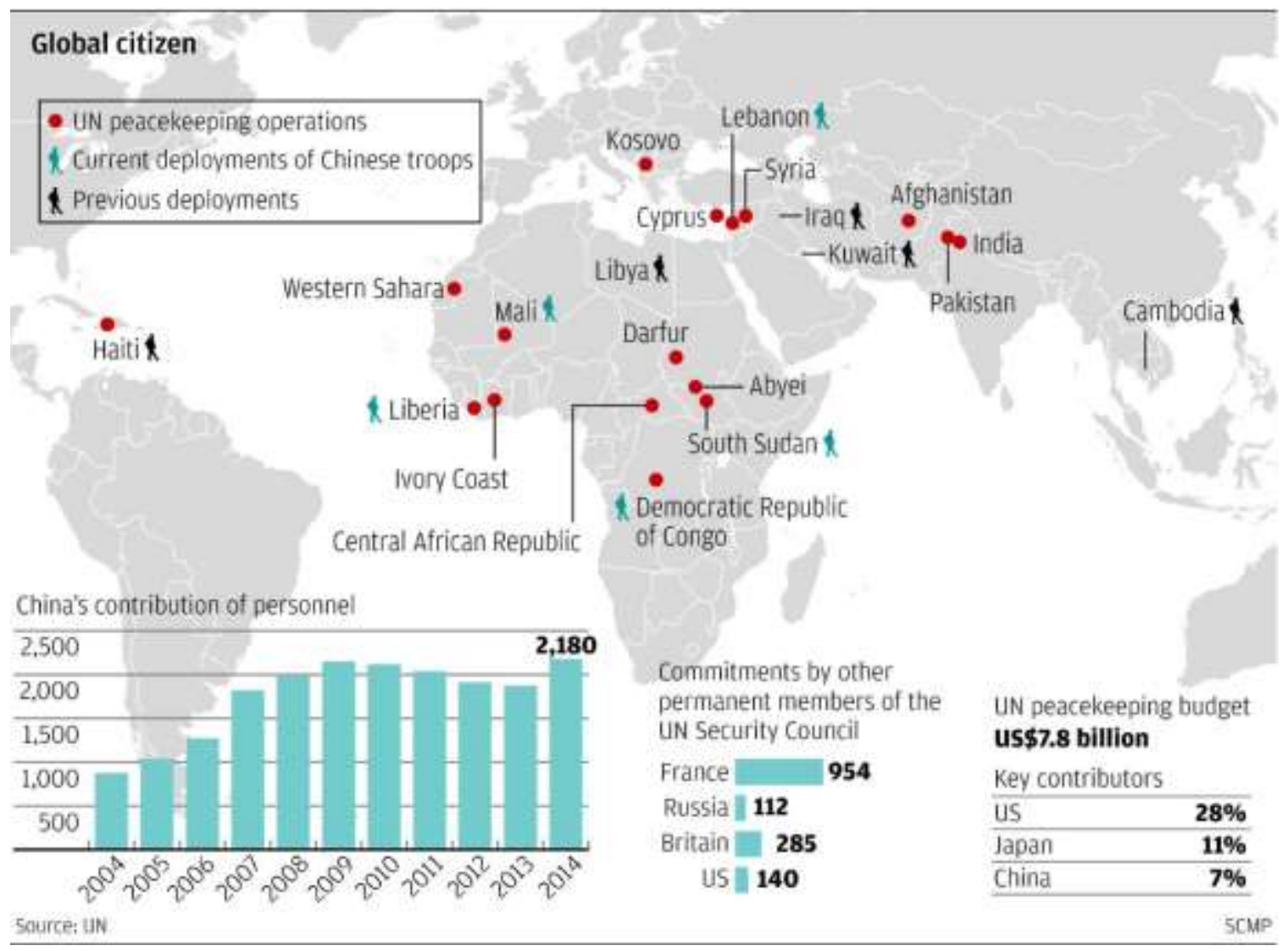

Illustration 6: United Nations Peacekeeping Operations and Chinese Previous and Current Deployments (Source: UN \& South China Morning Post; available online at http://www.scmp.com/news/china/article/1521454/chinas-growing-peacekeepingcommitment-un-shows-shift-foreign-policy). 
VITA

\section{LUKAS KARL DANNER}

1986

2005-2011

2007-2008

2011-2015

2011-2016

2014

2015-2016

2015-2016

2016
Born, Dinkelsbühl, Bavaria, Federal Republic of Germany

M.A., Sinology, American Cultural History, Law

Ludwig-Maximilians-University of Munich (LMU)

Munich, Federal Republic of Germany

Scholarship Recipient

German Academic Exchange Council / China Scholarship Council

Beijing Foreign Studies University (BFSU)

Beijing, People's Republic of China

Teaching Assistant

Department of Politics and International Relations

Florida International University (FIU)

Miami, Florida

Doctoral Candidate

Department of Politics and International Relations

Florida International University

M.A., International Studies \& Graduate Certificate in Asian Studies Department of Politics and International Relations

Florida International University

Adjunct Lecturer

Department of Politics and International Relations

Florida International University

Fellowship Recipient (Thomas J. Smith Non-Resident Fellow)

Humane Studies Fellowship

The Institute for Humane Studies (IHS)

Washington, D.C.

Fellowship Recipient

Dissertation Year Fellowship (DYF), University Graduate School

Florida International University

\section{PUBLICATIONS AND PRESENTATIONS}

"Rising Assertiveness Versus Peaceful Development: Making Sense of China's Ambivalent International Behavior," Culture Mandala 12:1 (December 2016), pp. 23-44. 
"Review: So, Alvin Y., and Yin-wah Chu, The Global Rise of China. Cambridge: Polity Press, 2016. 232 pp.," in American Journal of Chinese Studies 23:2 (October 2016).

“China's Contradictory Grand Strategy Manifestations: Examining the Rare Earths Export Restrictions and the One Belt, One Road Initiative," Tamkang Journal of International Affairs 20:1 (July 2016), pp. 1-60.

"Implications of the Dragon's Rise for South Asia: Assessing China's Nepal Policy," Strategic Analysis 40:1 (January 2016), pp. 26-40 (with Bibek Chand).

"Review: Halper, Stefan A. Beijing Consensus: Legitimizing Authoritarianism in Our Time. New York, NY: Basic Books, [2010] 2012. 336 pp.," in American Journal of Chinese Studies 22:1 (April 2015), pp. 104-106.

"Securitization and De-Securitization in the Diaoyu/Senkaku Islands Dispute," Journal for Alternative Perspectives in the Social Sciences 6:2 (November 2014), pp. 219-247.

"Foreign Relations - Northeast Asia," In: Brian Franklin, ed., The Collective Memory Project (CMP) on the Election of 2004 (November 2014).

"Review: Yueh, Linda. China's Growth. New York, NY: Oxford University Press, 2013. 384 pp," in American Journal of Chinese Studies 21:1 (April 2014), pp. 69-70.

“A Regional Security Complex Account of the Diaoyu/Senkaku Islands Dispute [以地区 安全复合体理论解读钓鱼岛/尖阁诸岛冲突], ” Bond University e-Publications: East Asia Security Center (February 2014), pp. 1-8.

"Review: Kang, David C. East Asia before the West. New York, NY: Columbia University Press, 2010. 221 pp," in Journal of Third World Studies 30:2 (September 2013), pp. 253255.

"Review: McNeal, Robin. Conquer and Govern. Honolulu, HI: University of Hawai'i Press, 2012. 246 pp," in American Journal of Chinese Studies 20:1 (April 2013), pp. 78-79.

Papers presented at the 54 $4^{\text {th }}, 55^{\text {th }}, 57^{\text {th }}$, and $58^{\text {th }}$ Annual Meetings of the American Association for Chinese Studies; the 2016 Annual Conference of the International Security Studies Section of ISA and the International Security and Arms Control Section of APSA; the $74^{\text {th }}$ Annual Conference of the Midwest Political Science Association; the $55^{\text {th }}, 56^{\text {th }}$, and $57^{\text {th }}$ Annual Conventions of the International Studies Association; the EU Development Policy in a Global Context Conference; the 2015 ECPR Annual Conference; the $4^{\text {th }}$ WISC Global International Studies Conference; the Annual Meeting of the Florida Political Science Association; the 2013 Communicating Soft Power Conference of the University of Westminster; the 2013 Conference of the International Forum for Contemporary Chinese Studies; the Tenth Annual East Asia Security Symposium and Conference; the $67^{\text {th }}$ Annual Meeting of the NYSPSA; the China's Global Impact International Conference. 